Cláudia Akemi Pereira Namiki

\title{
Influência das massas de água sobre a distribuição das larvas de Myctophidae (Teleostei) e análise de aspectos biológicos de Myctophum affine na costa sudeste do Brasil $\left(22^{\circ} \mathrm{S}-25^{\circ} \mathrm{S}\right)$
}

Tese apresentada ao Instituto Oceanográfico da Universidade de São Paulo, como parte dos requisitos para obtenção do título de Doutor em Ciências, área de Oceanografia Biológica

Orientador: Prof. Dr. Mario Katsuragawa

São Paulo

2013 


\section{Universidade de São Paulo Instituto Oceanográfico}

Influência das massas de água sobre a distribuição das larvas de Myctophidae (Teleostei) e análise de aspectos biológicos de Myctophum affine na costa sudeste do Brasil $\left(22^{\circ} \mathrm{S}-25^{\circ} \mathrm{S}\right)$

\section{Cláudia Akemi Pereira Namiki}

Tese apresentada ao Instituto Oceanográfico da Universidade de São Paulo, como parte dos requisitos para obtenção do título de Doutor em Ciências, área de Oceanografia Biológica.

Julgada em

Prof(a). Dr(a).

Conceito

Prof(a). Dr(a).

Conceito

Prof(a). Dr(a).

Conceito

Prof(a). Dr(a).

Conceito

Prof(a). Dr(a).

Conceito 


\section{Sumário}

Agradecimentos …................................................................... i

Lista de Tabelas .................................................................................. iv

Lista de Figuras ...................................................................... vi

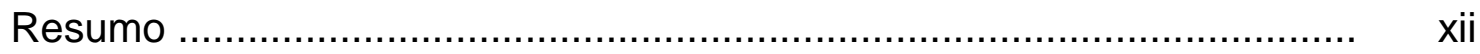

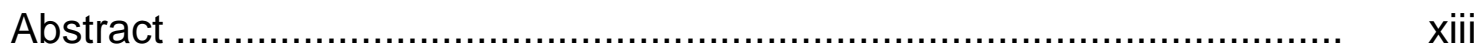

Introdução Geral ......................................................................

Objetivo geral ......................................................................... 5

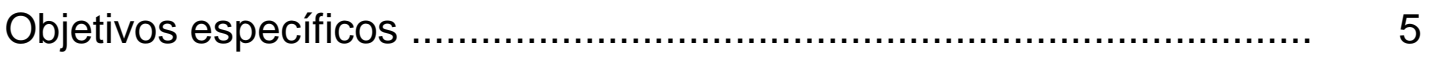

Área de estudo ……...................................................................

Material e métodos ….....................................................................

Capítulo 1. Influência das massas de água sobre a distribuição vertical e horizontal das larvas de peixes-lanterna (Myctophidae) ...... 10

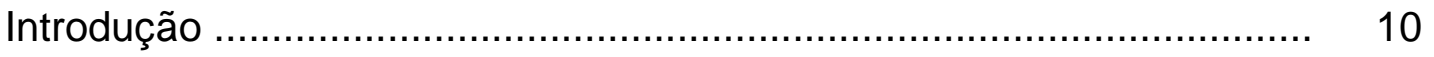

Material e métodos …................................................................... 12

Metodologia de laboratório .......................................................... 12

Análise dos dados .................................................................. 12

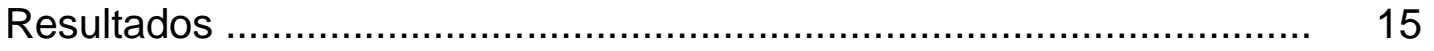

Condições oceanográficas ......................................................... 15

Composição taxonômica e abundância .......................................... 16

Distribuição horizontal ............................................................ 18 
Distribuição vertical .............................................................. 20

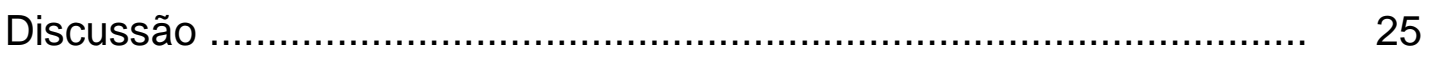

Composição taxonômica ................................................................ 25

Distribuição horizontal ............................................................... 26

Distribuição vertical ............................................................... 29

Capítulo 2. Crescimento e mortalidade das larvas de Myctophum affine ............................................................................................ 87

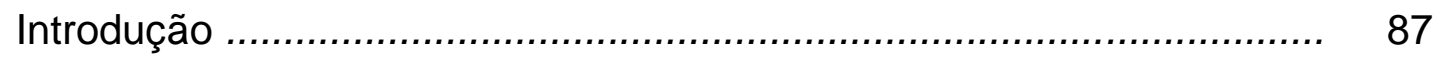

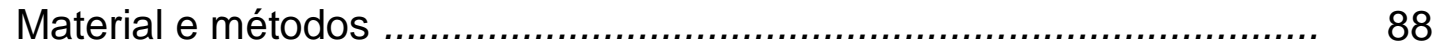

Metodologia de campo …...................................................... 88

Metodologia de laboratório ........................................................ 89

Análise dos dados .................................................................. $\quad 90$

Resultados ............................................................................ 92

Comprimento, idade e estágios de desenvolvimento ........................ 92

Modelos de crescimento .......................................................... 93

Mortalidade ............................................................................. 93

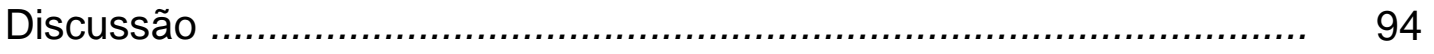

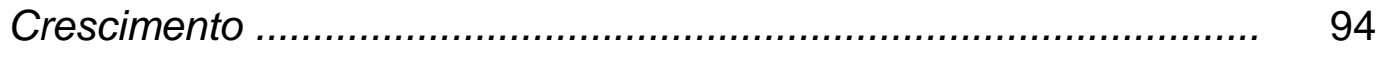

Mortalidade ......................................................................... 97

Capítulo 3. Condição nutricional das larvas de Myctophum affine baseada na análise histológica dos hepatócitos .............................. 104

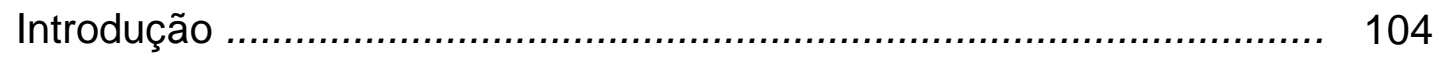


Material e métodos ............................................................... 106

Metodologia de campo ............................................................... 106

Metodologia de laboratório ............................................................ 106

Análise dos dados ...................................................................... 108

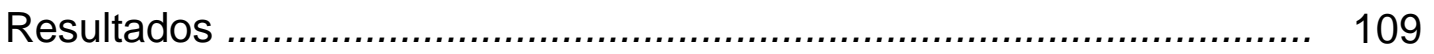

Análise histológica dos hepatócitos ............................................. 110

Níveis de glicogênio ................................................................. 111

Relação entre a análise histológica dos hepatócitos e os níveis de glicogênio ............................................................................. 112

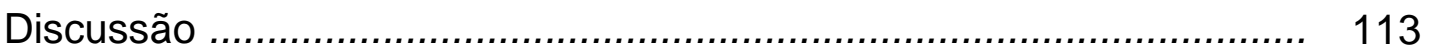

Análise histológica dos hepatócitos .............................................. 113

Níveis de glicogênio ............................................................. 115

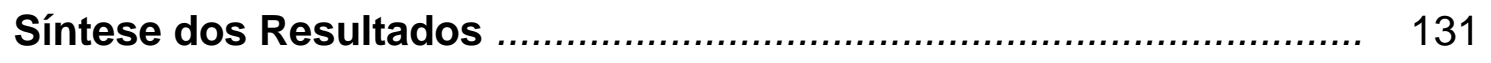

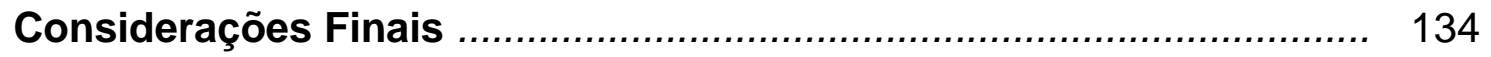

Referências Bibliográficas ................................................... 135 


\section{Agradecimentos}

Ao Professor Mario Katsuragawa pela orientação, oportunidade, ensinamentos, incentivo, paciência e sobretudo confiança. Espero que esse trabalho renda bons frutos! Muito obrigada por tudo!

À Maria de Lourdes Zani-Teixeira, sem a qual eu provavelmente não conseguiria sobreviver! Obrigada pelo seu constante bom humor, paciência e solicitude. Obrigada pelos ensinamentos na área de informática, saúde, música, ciência e muito mais. Obrigada pela ajuda no inicio, meio e fim dessa tese. Trabalhar com você é ótimo!

Ao CNPq pela bolsa concedida.

Ao Instituto Oceanográfico pelo uso de suas instalações.

A todos os funcionários do IO que fazem com que tudo funcione sem nos darmos conta.

Aos funcionários da biblioteca que sempre nos recebem prontos para ajudar: Wagner Pinheiro pelas incontáveis vezes que encontrou artigos mundo afora; Cidinha, Marta e Daniel, sempre muito simpáticos, solícitos e eficientes; $A$ inesquecível Dona Rai e o pessoal do backstage, principalmente Maria Pureza e Claudinha.

Ao Valter Miyagi pelas inúmeras vezes que me ajudou com problemas de BIOS. Agora sempre guardo arquivos importantes nas nuvens.

À Ana Paula, Silvana e Letícia, por sempre me socorrerem com informações imprescindíveis sobre prazos, datas e documentos. Obrigada pela simpatia!

Ao Professor Ilson por ceder os dados das massas de água.

Ao Rafael Mattos, pela grande ajuda com os scripts do Matlab. Sem os mapas de massa de água essa tese não seria a mesma.

À Juliana Marson, por me ajudar a transformar os scripts do Matlab em figuras reais.

Ao Massami, pela ajuda com fotografias, informática, otólitos ou simplesmente pela sua amizade. Saudades amigo!

À Maysa Pompeu pela ajuda com os microscópios do DOB, e por me apresentar o 
Belo Antônio.

À Helcy Silbiger pela ajuda em todo o processamento histológico e ensinamentos sobre o até então misterioso mundo da histologia.

Ao André Luiz Veiga Conrado da Faculdade de Medicina Veterinária da Universidade de São Paulo pelas fotografias das lâminas.

À amiga de vida e de trabalho Jana Janilda pela paciência e disposição para ler a tese e fazer muitas sugestões pertinentes! Você merece um poema por gastar seu sábado de sol em prol dessa tese. Mas como não sou boa nisso, acho melhor só dizer muuuuito obrigada mesmo!

À Isa, por estar sempre pronta a ajudar com sua sabedoria, e pela forcinha no Abstract!

Ao Bur, pelas longas discussões sobre identificação.

À Professora June, pelos ensinamentos nas disciplinas ou nas conversas no café e por toda atenção, amizade e carinho. Eu admiro muito seu trabalho e, além disso, você é Corinthians!

A todos os participantes do cafezinho MK, especialmente ao Professor Nonato pelos ótimos bates papos, que são uma lição de vida.

Aos amigos do laboratório ao lado Riguel, Eudriano, Wellington, Kenji; às amigas do laboratório do outro lado Catita Marcolin, Dani, Nairuta, Tulita e Izadora; às amigas(os) um pouquinho mais adiante Carolzita, Juliana, Michele Cacá, Dani B. e Maurício, pelas inúmeros conversas, bandex, risadas e momentos de ajuda em diversos assuntos. Obrigada por oferecerem sempre um ombro amigo e um ouvido atento!

As amigas de todas as horas, Camilla, Renatinha, Thassya e Aninha que me acolheram desde o início, e às amigas também de todas as horas, mas nem tão velhas assim, Mariana, Nayara e Giulia.

A Didi, Betão e Companhia. Obrigada pela simpatia e pelo lanche de todo dia! Aos amigos do Rio e das bandas do Pará.!

Aos eternos amigos do Lizi, meus eternos agradecimentos!

Aos amigos de São Paulo, tão perto e tão distante. 
A Fabi, minha irmã!

À Família Cahim!

À Neide e Jair, meus pais postiços!

Ao Toninho, por ter sempre uma palavra sábia e afetuosa. Muitas saudades de você!

À Dani minha cunhada-amiga-irmã pelo apoio moral!

À Marly, Dani, Paulo, Maê, Cintia, Inho e toda a família Grecco pelo carinho, momentos alegres e acolhimento!

Aos Pereiras que torcem por mim lá de Cascavel, principalmente minha afilhada Maria Eduarda.

Obrigada Tia Mari, madrinha, pela conversa animadora que tivemos faz algum tempo. Você também é um grande exemplo de dedicação e perseverança.

Ao meu irmão Rodrigo, minha cunha Silvia e meus sobrinhos mais lindos e fofos e queridos e amados desse mundo Yousuke e Gen! Amo muito vcs!

Ao meu grande amor e companheiro de todas as horas, Cesar. Obrigada por todo apoio e incentivo e principalmente por me aguentar nesse fim de tese. Te amo muito! Cada vez mais! Minha vida não teria tanta alegria sem você!

À Katherine, que também traz muita alegria para meus dias! Obrigada pelo incentivo e preocupação comigo! Amo você S2!

Ao meu pai Renato e minha mãe Luiza, pelo incentivo e apoio incondicionais. Vocês são um exemplo de determinação e coragem. Meu amor por vocês é infinito! Obrigada por acreditarem em mim!

E a todos aqueles que por acaso eu tenha esquecido de citar aqui, mas que fazem parte da minha vida e contribuíram de alguma maneira para a realização desse trabalho! 


\section{Lista de Tabelas}

Tabela 1.1: Número de indivíduos (N), abundância total (Abund.), porcentagem (\%), abundância média (média) e desvio padrão (dp) das larvas de Myctophidae coletadas com a malha fina da rede bongô, entre Cabo de São Tomé e São

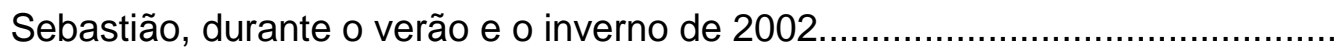

Tabela 1.2: Número de indivíduos (N), frequência de ocorrência (Fo \%.), densidade média (média) e desvio padrão (dp) das larvas de Myctophidae coletadas em estratos de $20 \mathrm{~m}$ de profundidade com a rede Multinet, entre cabo de São Tomé e São Sebastião, durante o verão de 2002.

Tabela 1.3: Número de indivíduos ( $\mathrm{N})$, frequência de ocorrência (Fo \%.), densidade média (média) e desvio padrão ( $\mathrm{dp}$ ) das larvas de Myctophidae coletadas em estratos de $20 \mathrm{~m}$ de profundidade com a rede Multinet, entre cabo de São Tomé e São Sebastião, durante o inverno de 2002.

Tabela 1.4: Resultado do teste de permutação de Monte Carlo em relação às variáveis ambientais e espaciais entre cabo de São Tomé e São Sebastião, durante o verão de 2002.

Tabela 1.5: Resultado da análise de partição das variáveis ambientais e espaciais para a explicação da distribuição das espécies de Myctophidae entre cabo de São Tomé e São Sebastião durante o verão de 2002.

Tabela 1.6: Resultado da análise de correspondência canônica e correlação da variáveis significativas com os quatro primeiros eixos, para a explicação da distribuição das espécies de Myctophidae entre cabo de São Tomé e São Sebastião durante o verão de 2002.

Tabela 1.7: Resultado do teste de permutação de Monte Carlo em relação às variáveis ambientais e espaciais entre cabo de São Tomé e São Sebastião, durante o inverno de 2002.

Tabela 1.8: Resultado da análise de partição das variáveis ambientais e espaciais para a explicação da distribuição das espécies de Myctophidae entre cabo de São Tomé e São Sebastião durante o inverno de 2002. ....

Tabela 1.9: Resultado da análise de correspondência canônica e correlação da variáveis significativas com os quatro primeiros eixos, para a explicação da distribuição das espécies de Myctophidae entre cabo de São Tomé e São Sebastião durante o inverno de 2002. 
Tabela 2.1: Comparação das taxas de crescimento diária, comprimento padrão no momento da eclosão (E) e no início da transformação (T) e duração do período larval das larvas de Myctophidae analisadas em diversas localidades. ..

100

Tabela 3.1: Critérios para a classificação histológica dos hepatócitos de larvas de Myctophum affine, baseado em Margulies (1993) e Diaz et al. (2011b).

Tabela 3.2: Frequência de ocorrência (\%) das classes histológicas dos hepatócitos de Myctophum affine em relação aos fatores analisados.

Tabela 3.3: Resultados do teste de Kruska-Wallis e teste a posteriori de Dunn para a condição dos hepatócitos de Myctophum affine entre os estágios de desenvolvimento pré-flexão, flexão e pós-flexão.

Tabela 3.4: Resultados do teste de Kruska-Wallis e teste a posteriori de Dunn para a condição dos hepatócitos de Myctophum affine entre as regiões de coleta, englobando as amostras dos dois cruzeiros.

Tabela 3.5: Resultados do teste de Kruska-Wallis e teste a posteriori de Dunn para a condição dos hepatócitos de Myctophum affine entre as regiões de coleta, durante o cruzeiro de verão.

Tabela 3.6: Frequência de ocorrência (\%) dos níveis de glicogênio nos hepatócitos de Myctophum affine em relação aos fatores analisados.

Tabela 3.7: Frequência de ocorrência (\%) dos níveis de glicogênio nos hepatócitos de Myctophum affine em relação ao estágio de desenvolvimento e período do dia.

Tabela 3.8: Resultados do teste de Kruska-Wallis e teste a posteriori de Dunn para os níveis de glicogênio nos hepatócitos de Myctophum affine entre as classes histológicas dos hepatócitos. ns= não significativo. 


\section{Lista de Figuras}

Figura 1: Área de estudo e localização das estações de coleta entre cabo de São

Tomé e ilha de São Sebastião, realizadas em janeiro e agosto de 2002.......

Figura 1.1: Diagramas T-S mostrando a presença das massas de água, Água Costeira (AC), Água Tropical (AT) e Água Central do Atlântico Sul (ACAS), entre cabo de São Tomé (RJ) e ilha de São Sebastião (SP) durante o verão e o inverno de 2002.

Figura 1.2: Distribuição percentual das massas de água Água Costeira (AC), Água Tropical (AT) e Água Central do Atlântico Sul (ACAS) entre cabo de São Tomé e ilha de São Sebastião durante o verão de 2002.

Figura 1.3: Distribuição percentual das massas de água Água Costeira (AC), Água Tropical (AT) e Água Central do Atlântico Sul (ACAS) entre cabo de São Tomé e ilha de São Sebastião durante o inverno de 2002.

Figura 1.4: Distribuição horizontal e abundância das larvas de Myctophum affine entre cabo de São Tomé e ilha de São Sebastião durante o verão $(A)$ e o inverno (B) de 2002.

Figura 1.5: Distribuição horizontal e abundância das larvas de Diaphus tipo stubby entre cabo de São Tomé e ilha de São Sebastião durante o verão $(A)$ e o inverno (B) de 2002.

Figura 1.6: Distribuição horizontal e abundância das larvas de Diaphus tipo slender entre cabo de São Tomé e ilha de São Sebastião durante o verão $(A)$ e o inverno (B) de 2002.

Figura 1.7: Distribuição horizontal e abundância das larvas de Lepidophanes guentheri entre cabo de São Tomé e ilha de São Sebastião durante o verão $(A)$ e o inverno (B) de 2002.

Figura 1.8: Distribuição horizontal e abundância das larvas de Lepidophanes spp. entre cabo de São Tomé e ilha de São Sebastião durante o verão $(A)$ e o inverno (B) de 2002.

Figura 1.9: Distribuição horizontal e abundância das larvas de Benthosema suborbitale entre cabo de São Tomé e ilha de São Sebastião durante o verão (A) e o inverno (B) de 2002.

Figura 1.10: Distribuição horizontal e abundância das larvas de Hygophum hygomii entre cabo de São Tomé e ilha de São Sebastião durante o verão $(A)$ e inverno (B) de 2002. 
Figura 1.11: Distribuição horizontal e abundância das larvas de Hygophum reinhardtii entre cabo de São Tomé e ilha de São Sebastião durante o verão $(A)$ e o inverno (B) de 2002.

Figura 1.12: Distribuição horizontal e abundância das larvas de Myctophum obtusirostre entre cabo de São Tomé e ilha de São Sebastião durante o verão (A) e o inverno (B) de 2002.

Figura 1.13: Distribuição horizontal e abundância das larvas de Ceratoscopelus spp. entre cabo de São Tomé e ilha de São Sebastião durante o verão (A) e o inverno (B) de 2002.

Figura 1.14: Distribuição horizontal e abundância das larvas de Notolychnus valdiviae. entre cabo de São Tomé e ilha de São Sebastião durante o verão $(A)$ e o inverno (B) de 2002.

Figura 1.15: Distribuição horizontal e abundância das larvas de Centrobranchus nigroocellatus, Myctophum asperum, M. nitidulum, M. selenops, Lampadena sp., Lobianchia gemellari e Nannobrachium sp. entre cabo de São Tomé e ilha de São Sebastião durante o verão (A) e o inverno (B) de 2002.

Figura 1.16: Distribuição horizontal e abundância das larvas de Lampanyctus tipos 1 (A) e Lampanyctus tipo 2 (B) entre cabo de São Tomé e ilha de São Sebastião durante o inverno de 2002.

Figura 1.17: Distribuição horizontal e abundância das larvas de Notoscopelus caudispinosus entre cabo de São Tomé e ilha de São Sebastião durante o inverno de 2002.

Figura 1.18: Distribuição horizontal e abundância das larvas de Symbolophorus rufinus entre cabo de São Tomé e ilha de São Sebastião durante o inverno de 2002.

Figura 1.19: Diagramas de ordenação da análise de correspondência canônica com as variáveis ambientais (vetores) e espécies de Myctophidae (A) e amostras (B), coletadas entre cabo de São Tomé e ilha de São Sebastião durante o verão de 2002.

Figura 1.20: Distribuição vertical das larvas de Symbolophorus rufinus entre 0$100 \mathrm{~m}$ de profundidade em relação à distribuição das porcentagens de massa de água entre cabo de São Tomé e ilha de São Sebastião durante o verão de 2002. 
Figura 1.21: Distribuição vertical das larvas de Notolychnus valdiviae entre 0-100 $\mathrm{m}$ de profundidade em relação à distribuição das porcentagens de massa de água entre cabo de São Tomé e ilha de São Sebastião durante o verão de 2002.

Figura 1.22: Distribuição vertical das larvas de Lobianchia gemellari entre 0-100 $\mathrm{m}$ de profundidade em relação à distribuição das porcentagens de massa de água entre cabo de São Tomé e ilha de São Sebastião durante o verão de 2002.

Figura 1.23: Distribuição vertical das larvas de Hygophum reinhardti entre 0-100 $\mathrm{m}$ de profundidade em relação à distribuição das porcentagens de massa de água entre cabo de São Tomé e ilha de São Sebastião durante o verão de 2002.

Figura 1.24: Distribuição vertical das larvas de Benthosema suborbitale entre 0$100 \mathrm{~m}$ de profundidade em relação à distribuição das porcentagens de massa de água entre cabo de São Tomé e ilha de São Sebastião durante o verão de 2002.

Figura 1.25: Distribuição vertical das larvas de Myctophum obtusirostre entre 0$100 \mathrm{~m}$ de profundidade em relação à distribuição das porcentagens de massa de água entre cabo de São Tomé e ilha de São Sebastião durante o verão de 2002.

Figura 1.26: Distribuição vertical das larvas de Diaphus tipo stubby entre 0-100 m de profundidade em relação à distribuição das porcentagens de massa de água entre cabo de São Tomé e ilha de São Sebastião durante o verão de 2002.

Figura 1.27: Distribuição vertical das larvas de Diaphus tipo slender entre 0-100 $\mathrm{m}$ de profundidade em relação à distribuição das porcentagens de massa de água entre cabo de São Tomé e ilha de São Sebastião durante o verão de 2002.

Figura 1.28: Distribuição vertical das larvas de Lepidophanes guentheri entre 0$100 \mathrm{~m}$ de profundidade em relação à distribuição das porcentagens de massa de água entre cabo de São Tomé e ilha de São Sebastião durante o verão de 2002.

Figura 1.29: Distribuição vertical das larvas de Myctophum affine entre 0-100 m de profundidade em relação à distribuição das porcentagens de massa de água entre cabo de São Tomé e ilha de São Sebastião durante o verão de 2002. 
Figura 1.30: Distribuição vertical das larvas de Ceratoscopelus sp. entre 0-100 $\mathrm{m}$ de profundidade em relação à distribuição das porcentagens de massa de água entre cabo de São Tomé e ilha de São Sebastião durante o verão de 2002.

Figura 1.31: Distribuição vertical das larvas de Diogenichthys atlanticus entre 0$100 \mathrm{~m}$ de profundidade em relação à distribuição das porcentagens de massa de água entre cabo de São Tomé e ilha de São Sebastião durante o verão de 2002.

Figura 1.32: Distribuição vertical das larvas de Nannobrachium sp. entre 0-100 $\mathrm{m}$ de profundidade em relação à distribuição das porcentagens de massa de água entre cabo de São Tomé e ilha de São Sebastião durante o verão de 2002.

Figura 1.33: Distribuição vertical das larvas de Myctophum asperum entre 0-100 $\mathrm{m}$ de profundidade em relação à distribuição das porcentagens de massa de água entre cabo de São Tomé e ilha de São Sebastião durante o verão de 2002.

Figura 1.34: Diagramas de ordenação da análise de correspondência canônica com as variáveis ambientais (vetores) e espécies de Myctophidae (A) e amostras (B), coletadas entre cabo de São Tomé e ilha de São Sebastião durante o inverno de 2002.

Figura 1.35: Distribuição vertical das larvas de Benthosema suborbitale entre 0$100 \mathrm{~m}$ de profundidade em relação à distribuição das porcentagens de massa de água entre cabo de São Tomé e ilha de São Sebastião durante o inverno de 2002.

Figura 1.36: Distribuição vertical das larvas de Lampanyctus tipo 2 entre 0-100 $\mathrm{m}$ de profundidade em relação à distribuição das porcentagens de massa de água entre cabo de São Tomé e ilha de São Sebastião durante o inverno de 2002.

Figura 1.37: Distribuição vertical das larvas de Symbolophorus rufinus entre 0$100 \mathrm{~m}$ de profundidade em relação à distribuição das porcentagens de massa de água entre cabo de São Tomé e ilha de São Sebastião durante o inverno de 2002.

Figura 1.38: Distribuição vertical das larvas de Myctophum affine entre 0-100 m de profundidade em relação à distribuição das porcentagens de massa de água entre cabo de São Tomé e ilha de São Sebastião durante o inverno de 2002. .... 
Figura 1.39: Distribuição vertical das larvas de Diaphus tipo stubby entre 0-100 $\mathrm{m}$ de profundidade em relação à distribuição das porcentagens de massa de água entre cabo de São Tomé e ilha de São Sebastião durante o inverno de 2002.

Figura 1.40: Distribuição vertical das larvas de Myctophum obtusirostre entre 0$100 \mathrm{~m}$ de profundidade em relação à distribuição das porcentagens de massa de água entre cabo de São Tomé e ilha de São Sebastião durante o inverno de 2002.

Figura 1.41: Distribuição vertical das larvas de Hygophum hygomii entre 0-100 $\mathrm{m}$ de profundidade em relação à distribuição das porcentagens de massa de água entre cabo de São Tomé e ilha de São Sebastião durante o inverno de 2002.

Figura 1.42: Distribuição vertical das larvas de Hygophum reinhardti entre 0-100 $\mathrm{m}$ de profundidade em relação à distribuição das porcentagens de massa de água entre cabo de São Tomé e ilha de São Sebastião durante o inverno de 2002.

Figura 1.43: Distribuição vertical das larvas de Lampanyctus tipo 1 entre 0-100 $\mathrm{m}$ de profundidade em relação à distribuição das porcentagens de massa de água entre cabo de São Tomé e ilha de São Sebastião durante o inverno de 2002.

Figura 1.44: Distribuição vertical das larvas de Diaphus tipo slender entre 0-100 $\mathrm{m}$ de profundidade em relação à distribuição das porcentagens de massa de água entre cabo de São Tomé e ilha de São Sebastião durante o inverno de 2002.

Figura 1.45: Distribuição vertical das larvas de Myctophum nitidulum entre 0$100 \mathrm{~m}$ de profundidade em relação à distribuição das porcentagens de massa de água entre cabo de São Tomé e ilha de São Sebastião durante o inverno de 2002.

Figura 1.46: Distribuição vertical das larvas de Notoscopelus caudispinosus entre 0-100 $\mathrm{m}$ de profundidade em relação à distribuição das porcentagens de massa de água entre cabo de São Tomé e ilha de São Sebastião durante o inverno de 2002.

Figura 1.47: Distribuição vertical das larvas de Lepidophanes guentheri entre 0$100 \mathrm{~m}$ de profundidade em relação à distribuição das porcentagens de massa de água entre cabo de São Tomé e ilha de São Sebastião durante o inverno de 2002. 
Figura 2.1: Distribuição de frequência (\%) das classes de comprimento padrão $(\mathrm{mm})$ das larvas de Myctophum affine, durante o verão $(n=178)$ e o inverno $(n=$ 38) de 2002, entre cabo de São Tomé e ilha São Sebastião.

Figura 2.2: Distribuição de frequência (\%) da idade (dias), estimada a partir da contagem dos anéis de crescimento dos otólitos sagitta, das larvas de Myctophum affine, no verão $(n=74)$ e inverno $(n=10)$ de 2002, entre cabo de São Tomé e São Sebastião.

Figura 2.3: Curvas de crescimento das larvas de Myctophum affine estimadas através dos modelos de Laird-Gompertz, exponencial e linear. A idade foi estimada através da contagem dos anéis de crescimento dos otólitos sagitta durante o verão e o inverno de 2002, entre cabo de São Tomé e ilha de São Sebastião.

Figura 2.4: Taxa diária de crescimento das larvas de Myctophum affine, estimada através da regressão linear e da derivada do modelo de LairdGompertz, Os dados de idade dos modelos foram estimados através da contagem dos anéis de crescimento dos otólitos sagitta, durante o verão e o inverno de 2002 entre cabo de São Tomé e São Sebastião.

Figura 2.5: Coeficiente de mortalidade instantânea (Z) das larvas de Myctophum affine.

Figura 3.1: Larvas de Myctophum affine coradas previamente com eosina e emblocadas em parafina para a obtenção dos cortes histológicos

Figura 3.2: Cortes histológicos do fígado das larvas de Myctophum affine caracterizando diferentes classes de condição nutricional.

Figura 3.3: Cortes histológicos do fígado das larvas de Myctophum affine caracterizando diferentes níveis de glicogênio nos hepatócitos.

Figura 3.4: (a) Níveis de glicogênio e (b) classificação histológica dos hepatócitos das larvas Myctophum affine em diferentes horários, durante o verão e o inverno de 2002, entre cabo de São Tomé e ilha de São Sebastião. ...

Figura 3.5: Comparação entre as classes histológicas e os níveis de glicogênio dos hepatócitos de Myctophum affine coletadas durante o verão e o inverno de 2002, entre cabo de São Tomé e ilha de São Sebastião. 


\section{Resumo}

Com o objetivo de investigar a influência das massas de água sobre a distribuição horizontal e vertical das larvas de Myctophidae e de analisar a condição nutricional, o crescimento e a mortalidade de Myctophum affine, amostragens foram realizadas através de arrastos oblíquos (rede bongô) e estratificados (rede Multinet), em águas do sudeste brasileiro, desde a costa até o talude, entre cabo de São Tomé (RJ) e ilha de São Sebastião (SP). A intrusão da Água Central do Atlântico Sul diminuiu a extensão da Água Tropical (AT) sobre a plataforma. Como as larvas de Myctophidae foram associadas à AT, esse processo reduziu a ocorrência dessas larvas na plataforma. As espécies apresentaram diferentes padrões de distribuição vertical e horizontal, ressaltando a importância da identificação em nível taxonômico específico para a obtenção de um padrão de distribuição mais refinado. A análise histológica dos hepatócitos de Myctophum affine, a espécie mais abundante, evidenciou que a maioria das larvas estava em boa condição nutricional; apenas aquelas nos estágios menos avançados apresentavam sinais de inanição severa. Sua taxa de crescimento média $(0,33$ $\mathrm{mm} / \mathrm{dia}$ ) foi considerada intermediária entre os mictofídeos e a duração de seu período larval uma das menores. A taxa de mortalidade $(11,8 \%)$ ficou abaixo da média obsevada para espécies de peixes marinhos, sendo similar a de alguns epipelágicos da região. Dessa forma, a alta abundância, baixa taxa de mortalidade e boa condição nutricional das larvas de $M$. affine mostraram que essa área é um importante berçário para essa espécie, e provavelmente para outros mictofídeos.

Palavras-chave: ictioplâncton, peixes-lanterna, distribuição vertical, distribuição horizontal, condição nutricional, crescimento, mortalidade, Corrente do Brasil. 


\begin{abstract}
In order to investigate the influence of water masses on the horizontal and vertical distribution of Myctophidae larvae and to analyze the nutritional condition, growth and mortality of Myctophum affine, oblique and stratified tows were done using bongo net and Multinet respectively, in the southeastern Brazilian Bight, between São Tomé cape (RJ) and São Sebastião island (SP) from the coastal region to the continental slope. The intrusion of South Atlantic Central Water (SACW) reduced the extent of Tropical Water (TW) over the shelf. As Myctophidae larvae were associated with TW, this process reduced larval abundance in the shelf. Species showed different patterns of vertical and horizontal distribution, emphasizing the importance of identification at species level to obtain a more detailed distribution pattern. Histological analysis of hepatocytes of the $M$. affine, the most abundant species, showed that the majority of larvae was in good nutritional condition; only those in early stages presented signs of severe starvation. The average growth rate of the $M$. affine $(0.33 \mathrm{~mm} /$ day $)$ was considered intermediate among lanternfishes, and the duration of its larval period is among the shortest one. The mortality rate (11.8\%) was below average compared with other marine fish species, but it was similar to some epipelagic fishes that occur in the region. Therefore, high abundance, low mortality rate and good nutritional condition of $M$. affine larvae, showed that this is an important nursery area for this species, and probably to other lanternfishes.
\end{abstract}

Key words: ichthyoplankton, lanternfish, vertical distribution, horizontal distribution, nutritional condition, growth, mortality, Brazil Current. 


\section{Introdução Geral}

Os peixes mesopelágicos compreendem 31 famílias, dentre as quais Myctophidae é uma das mais abundantes (Gjøsaeter \& Kawaguchi, 1980). As espécies dessa família são conhecidas como peixes-lanterna, devido à presença de uma variedade de órgãos luminosos, denominados fotóforos. O número de fotóforos e sua disposição são as principais características utilizadas na identificação, pois são praticamente exclusivos de cada espécie (Nafpaktitis et al., 1977). Existem pelo menos 240 espécies, pertencentes a 32 gêneros (Nelson, 2006), amplamente distribuídas em todos os oceanos, desde a região Ártica até a Antártica (Gjøsaeter \& Kawaguchi, 1980). Em águas brasileiras já foram registradas 81 espécies, representando 23 gêneros (Braga et al., 2008; Santos \& Figueiredo, 2008).

A biomassa mundial de Myctophidae foi estimada em mais de 600 milhões de toneladas (Hulley, 1994). Porém poucas espécies foram comercialmente exploradas, como Lampanyctodes hectoris na costa africana (Gjøsaeter \& Kawaguchi, 1980), ou tiveram seu potencial como recurso pesqueiro avaliado, como Benthosema pterotum (Valinassab et al., 2007). A maioria das espécies é utilizada na produção de farinha de peixe e ração animal (Gjøsaeter \& Kawaguchi, 1980; Valinassab et al., 2007).

Os mictofídeos são considerados peças chave na teia trófica oceânica, pois estão entre os principais vertebrados consumidores de crustáceos zooplanctônicos (Hopkins et al., 1996) e compõem a dieta de várias espécies de peixes (Zavala-Camin et al., 1991; Hopkins et al., 1996; Muto et al., 2005; Collins et al., 2007; Fischer, 2012), cetáceos (Spitz et al., 2010) e aves (Neves et al., 2011). Na região circumpolar chegam a substituir o krill na alimentação dos leões marinhos (Reid et al., 2006; Collins et al., 2008). A maioria das espécies realiza migração vertical diária, ou seja, durante o dia permanecem nas regiões mais profundas, entre 300 e 2.000 m, e à noite migram para se alimentar nas camadas mais próximas da superfície, entre 10-100 m, sendo capturadas até mesmo no 
nêuston (Gjøsaeter \& Kawaguchi, 1980; Moser \& Ahlstrom, 1996). Esse comportamento tem importante função na transferência de matéria orgânica da zona epipelágica, mais produtiva, para as zonas meso e batipelágicas, mais pobres, podendo chegar até a região bentônica através de suas fezes (Robison \& Bailey, 1981).

O desenvolvimento larval tem sido descrito para diversas espécies de Myctophidae (Ozawa, 1986; Olivar \& Beckley, 1997; Sassa et al., 2002; Moser \& Watson, 2006). As larvas dos peixes-lanterna apresentam diversas características morfológicas e pigmentares que permitem a identificação das espécies e são muito úteis na análise sistemática (Moser et al., 1984; Ozawa, 1986; Moser \& Ahlstrom, 1996; Moser \& Watson, 2006). Por exemplo, todas as larvas da subfamília Myctophinae possuem olhos elípticos, enquanto as de Lampanyctinae possuem olhos arredondados (Moser \& Ahlstrom, 1974). O formato do corpo varia bastante entre as espécies, e quase todas as formas de larvas de teleósteos estão presentes nessa família (Moser, 1981). Essa diversidade de formas é acompanhada por uma variedade de hábitos alimentares, permitindo a coexistência de diferentes espécies (Sabatés \& Saiz, 2000; Conley \& Hopkins, 2004; Sassa \& Kawaguchi, 2005).

Estudos sobre o ictioplâncton abrangendo áreas além da região costeira têm demonstrado que as larvas de mictofídeos estão entre as mais abundantes nas assembleias oceânicas de larvas de peixes (Olivar \& Shelton, 1993; Franco \& Muelbert, 2003; Sassa et al., 2004a; Castro, 2006; Katsuragawa, 2007; Muhling et al., 2008a).

No Brasil, a maioria dos estudos do ictioplâncton se concentra na região costeira, e devido à escassez de coletas além da isóbata de $100 \mathrm{~m}$, os estudos sobre as larvas de Myctophidae são relativamente pouco numerosos. A distribuição e a abundância são os aspectos mais abordados, e a identificação, na maioria dos trabalhos, é feita até o nível taxonômico de família (Bonecker et al., 1992/93; Ekau \& Matsuura, 1996; Ekau et al., 1999; Nogueira et al., 1999; Franco \& Muelbert, 2003; Lopes, 2006; Franco et al., 2006). Segundo Leis (1993) a identificação até o nível de espécie detalha os padrões obtidos para as famílias. 
De fato, os poucos trabalhos que identificam as larvas de Myctophidae até espécie indicam que elas possuem diferentes padrões de distribuição espacial e sazonal (Nonaka et al., 2000; Bonecker \& Castro, 2006; Katsuragawa; 2007; Castro et al., 2010). As larvas de peixes sofrem influência de diversos fatores físicos e biológicos que atuam em diferentes escalas temporais e espaciais (Doyle et al., 1993). No entanto seus efeitos não são os mesmos sobre todas as espécies, pois o comportamento das larvas varia em relação ao ambiente (Marancik et al., 2005), e está associado, em parte, à sua grande diversidade morfológica (Moser, 1981).

Considerando uma escala espacial de alguns metros, a localização das larvas em uma determinada profundidade pode influenciar sua distribuição horizontal, visto que a direção e a velocidade das correntes podem variar de acordo com essa variável (Muhling et al., 2007). No entanto, a distribuição vertical das larvas de peixes é um aspecto ainda pouco estudado em águas brasileiras (Matsuura \& Kitahara,1995; Lopes, 2006; Goçalo et al., 2011; Bonecker et al., 2012).

Além do transporte, a variação espacial na abundancia das larvas de peixes pode estar relacionada com outros fatores que afetam a sua sobrevivência, como predação e disponibilidade de alimento (Houde, 2002). Quando as larvas não encontram alimento suficiente, entram em estado de inanição, que por si só é considerada uma causa direta da mortalidade (Cushing, 1974). Além disso, indivíduos em más condições nutricionais se desenvolvem e crescem mais lentamente e consequentemente são mais facilmente predados (Houde, 2002).

A condição nutricional das larvas de peixes tem sido estudada através de medidas morfométricas, proporção entre RNA:DNA (Clemmensen, 1996; Dias et al., 2004; Grote et al., 2012) ou através de índices histológicos, que consiste no estabelecimento de um sistema de classificação baseado na análise de células e órgãos (Ferron \& Leggett, 1994; Catalán, 2003). As larvas em inanição normalmente exibem degenerações nos tecidos, especialmente do trato digestório e glândulas associadas, como fígado e pâncreas. O fígado é um dos órgãos que responde mais rapidamente a privação de alimento, visto que os vacúolos dos hepatócitos estocam glicogênio e lipídio, que são as primeiras substâncias a 
serem mobilizadas em caso de inanição (O'Connell \& Paloma, 1981; Margulies, 1993; Chen et al., 2007).

Embora as larvas de peixes mesopelágicos sejam muito abundantes, apenas as do gênero Vincinguerria (Phosichthyidae) do Mar Arábico tiveram sua condição nutricional analisada (Sieg, 1992a). Na costa brasileira, estudos sobre a condição nutricional foram previamente realizados utilizando se a proporção entre RNA:DNA para as larvas de Sardinella brasiliensis (Clemmensen et al., 1997) e Engraulis anchoita (Rossi-Wongtschowski et al., 2003; Dias et al., 2004), e através da análise histológica apenas para essa última espécie (Sieg, 1998).

O crescimento é outro importante aspecto da biologia das larvas de peixes, e também está associado à sua sobrevivência, pois larvas que crescem mais rapidamente têm maiores chances de capturar as presas e de fugir dos predadores (Houde, 2002). A análise dos anéis de crescimento diário em otólitos sagitta vem sendo aplicada ao estudo do crescimento das larvas de diversas espécies e contribui para o conhecimento de parâmetros vitais, como idade, crescimento e mortalidade (Jones, 1986; Simms et al., 2008; Grote et al., 2012). Estudos sobre o crescimento de larvas de Myctophidae foram realizados no Pacífico Norte (Methot, 1981; Moku et al., 2005; Moku et al., 2001; Takagi et al., 2006) e no Golfo do México (Conley \& Gartner, 2009). Na costa brasileira, a maioria das informações sobre crescimento e/ou mortalidade na fase larval são de espécies costeiras de importância comercial (Kitahara \& Matsuura, 1995; Katsuragawa \& Ekau, 2003; Albuquerque et al., 2009). Em relação aos mesopelágicos, a taxa de crescimento foi calculada apenas para as larvas de Myctophum affine coletadas ao largo de Cabo Frio (Bruscagin, 2003).

Como visto, o número de estudos relativos à distribuição e aspectos biológicos dos mictofídeos e suas larvas na costa brasileira são escassos, principalmente se comparados à sua importância ecológica. 


\section{Objetivo geral}

Os dados desse trabalho foram obtidos durante a execução do projeto DEPROAS (Dinâmica do Ecossistema de Plataforma da Região Oeste do Atlântico Sul), que objetivou estudar os mecanismos físicos que possibilitam a intrusão sazonal da ACAS na plataforma continental situada entre cabo de São Tomé e São Sebastião, e o impacto dessa penetração sobre os processos biológicos do ecossistema da região, desde a plataforma interna até o talude.

Dentro desse contexto, o objetivo da presente tese foi analisar as larvas da família Myctophidae na área de estudo, procurando identificá-las em nível taxonômico específico, e descrever os padrões de distribuição horizontal e vertical dessas larvas em relação às massas de água presentes nos períodos de verão e inverno, assim como avaliar a condição nutricional, a taxa de crescimento e a taxa de mortalidade das larvas de Myctophum affine, a espécie mais abundante.

\section{Objetivos específicos}

A seguir são apresentados os objetivos específicos que serão tratados em três capítulos separadamente:

Capítulo 1

1.1- Verificar quais espécies de Myctophidae em estágio larval ocorrem na área de estudo;

1.2- Identificar mudanças na composição das espécies durante o verão e inverno;

1.3- Verificar a influência da distribuição das massas de água sobre os padrões de distribuição horizontal e vertical das espécies durante o verão e inverno.

Capítulo 2 
2.1- Avaliar a condição nutricional de Myctophum affine, a espécie mais abundante, através da análise histológica dos hepatócitos;

2.3- Verificar a existência de variação na condição nutricional de $M$. affine, de acordo com o estágio de desenvolvimento, local, e época de coleta.

Capítulo 3

3.1- Estimar a idade das larvas e a taxa de crescimento de $M$. affine através da leitura dos anéis de crescimento dos otólitos sagitta;

3.2- Estimar a taxa de mortalidade de M. affine na área de estudo.

\section{Área de estudo}

A área de estudo compreende a região entre cabo de São Tomé, RJ (22 S), e São Sebastião, SP ( $23^{\circ} 50^{\prime}$ S), que engloba parte da Plataforma Continental Sudeste e possui características dinâmicas típicas de plataformas continentais de latitudes médias (Figura 1) (Castro \& Miranda, 1998).

A Plataforma Continental Sudeste é a região da plataforma continental atlântica que se estende desde cabo Frio (RJ) até cabo de Santa Marta Grande (SC). Sua parte mais larga, com $230 \mathrm{~km}$ de extensão, está localizada em frente a Santos (SP) e estreita-se nas proximidades de cabo Frio, passando a $50 \mathrm{~km}$ (Castro et al., 2006). Sua topografia é suave com as isóbatas dispondo-se paralelamente a linha da costa, e a profundidade da quebra da plataforma continental variando entre 120 e 180 m (Zembruski, 1979).

A Corrente do Brasil (CB) domina a dinâmica da região, fluindo pela parte mais externa da plataforma (Castro, 1996). Ela é a corrente de contorno oeste associada ao giro subtropical do Atlântico Sul, com origem ao sul de $10^{\circ} \mathrm{S}$, onde a Corrente Sul Equatorial se bifurca (Silveira et al., 1994). A CB segue em direção ao sul, margeando o continente sul americano até a região da Convergência Subtropical, em torno de $38^{\circ} \mathrm{S}$, onde conflui com a Corrente das Malvinas e se separa da costa (Castro et al., 2006). A CB possui espessura de 400-700 m ao largo do Sudeste-Sul brasileiro, abrangendo o empilhamento das massas de água: Água 
Tropical (AT) e Água Central do Atlântico Sul (ACAS) (Silveira et al., 2000). A AT é parte da água quente e salina superficial do Atlântico Sul tropical (Emílsson, 1961), formada através da intensa radiação solar e excesso de evaporação em relação à precipitação (Castro et al., 2006). A ACAS, mais fria e menos salina, é formada por afundamento das águas na região da Convergênica Subtropical e encontrada na região da picnoclina (Castro et al., 2006). Sobre a plataforma interna nota-se a presença de uma terceira massa de água, a Água Costeira (AC), com baixos valores de salinidade e altas temperaturas (Castro et al., 1987).

Na região ao largo de cabo Frio a mudança na orientação da linha da costa, de NE-SW para E-W, provoca o afastamento da CB, mas a vorticidade potencial faz com que a corrente gire ciclonicamente para o oeste, alcançando novamente a quebra da plataforma em torno de 24ㅇS (Signorini, 1978; Castro \& Miranda, 1998). O gradiente da topografia de fundo, abrupta ao norte do cabo Frio e mais larga e suave na Bacia de Santos, também favorece a ocorrência de meandros e vórtices na CB (Campos, 1995; Rodrigues \& Lorenzzetti, 2001). Os meandramentos ciclônicos contribuem para o processo de ressurgência na quebra da plataforma e diversos trabalhos mostram que a água fria ressurgida em cabo Frio desloca-se na direção sudeste, chegando até mesmo nas proximidades de São Sebastião (Miranda, 1982; Lorenzzetti \& Gaeta, 1996; Calado et al., 2010). Esse processo é intensificado durante o verão pelo vento nordeste que sopra paralelo à costa, deslocando a água costeira superficial em direção ao oceano, permitindo que a ACAS ocupe esse espaço (Signorini, 1978; Castelao \& Barth, 2006). No inverno, há o predomínio de ventos sudeste, que são mais favoráveis à subsidência e à formação de vórtices anticiclônicos (Castelao \& Barth, 2006), tornando a ressurgência em cabo Frio menos intensa e propiciando a penetração da AT em várias áreas da plataforma interna.

\section{Material e métodos}

As amostras são provenientes de dois cruzeiros oceanográficos realizados a bordo do N/Oc. "Prof. W. Besnard", de 05 a 24 de janeiro (verão) e de 03 a 21 de 
agosto de 2002 (inverno). Foram realizadas coletas em 72 estações oceanográficas no verão e 66 no inverno, com espaçamento de $20 \mathrm{mn}$ e distribuídas em 14 radiais. As radiais estenderam-se desde a região nerítica até o talude, ultrapassando a isóbata de $2.000 \mathrm{~m}$ em algumas delas (Figura 1). Durante a realização dos cruzeiros, foram registrados as coordenadas geográficas, a profundidade local, os horários das coletas e os dados de temperatura e salinidade, esses últimos obtidos através de uma ecossonda e de um CTD, respectivamente, de cada estação oceanográfica. Os horários de coleta variaram entre as estações, incluindo os períodos diurno, noturno, aurora e crepúsculo.

As amostras de ictioplâncton foram obtidas com dois tipos de amostradores: com a rede bongô, constituída por duas redes de 0,29 $\mathrm{m}^{2}$ de boca e malhas de 333 $\mu \mathrm{m}$ e $505 \mu \mathrm{m}$, foram realizados arrastos oblíquos até a profundidade máxima de 200 m (Smith \& Richardson, 1977); com a Multinet, composta por cinco redes de malha $333 \mu \mathrm{m}$ e boca $0,25 \mathrm{~m}^{2}$, foram realizados arrastos em estratos de $20 \mathrm{~m}$, desde a superfície até $100 \mathrm{~m}$ de profundidade, em radiais alternadas. As amostras provenientes das redes de malha $333 \mu \mathrm{m}$ foram fixadas em solução de formaldeído tamponada com tetraborato de sódio, diluído em água do mar, a 4\%, para o estudo de distribuição e abundância das larvas; as da malha $505 \mu \mathrm{m}$ foram fixadas em álcool, para os estudos do crescimento e mortalidade (Capítulo 2) e condição nutricional larval (Capítulo 3).

As metodologias específicas para cada estudo serão descritas nos capítulos correspondentes. 


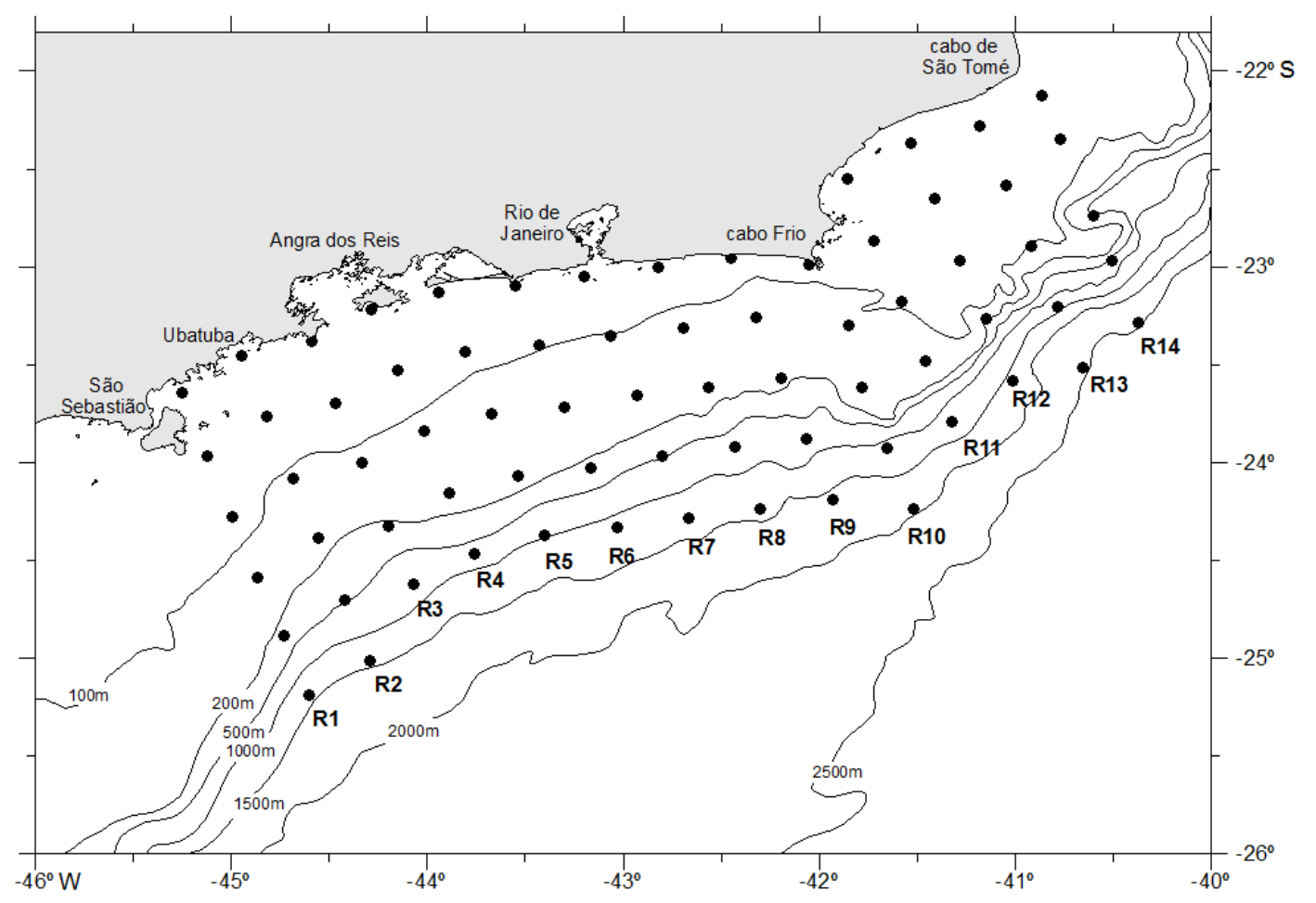

Figura 1: Área de estudo e localização das estações de coleta entre cabo de São Tomé e ilha de São Sebastião, realizadas em janeiro e agosto de 2002. R1 a R14= radiais. 


\section{Capítulo 1}

\section{Influência das massas de água sobre a distribuição vertical e horizontal das larvas de peixes-lanterna (Myctophidae)}

\section{Introdução}

Os peixes da família Myctophidae estão entre os principais componentes do ambiente mesopelágico (Nafpaktitis et al., 1977; Gjøsæter \& Kawaguchi, 1980; Hulley 1981), representando um elo importante da teia trófica oceânica, pois são um dos principais vertebrados consumidores de crustáceos zooplanctônicos (Hopkins et al., 1996) e servem de alimento para várias espécies de peixes (Zavala-Camin et al., 1991; Hopkins et al., 1996; Muto et al., 2005), cetáceos (Collins et al., 2008) e aves (Neves et al., 2011).

Essa família, composta por 240 espécies, está distribuída por todos os oceanos (Nelson, 2006) e sua maior diversidade é encontrada em águas oligotróficas das regiões tropical e subtropical (Backus et al., 1977). No Atlântico sudoeste foram registradas 81 espécies (Hulley, 1981; Braga et al., 2008; Santos e Figueiredo, 2008) e alguns estudos sobre peixes mesopelágicos comprovam a abundância dessa família na região (Hulley, 1981; Figueiredo et al., 2002; Santos, 2003; Bernardes et al., 2005; Braga et al., 2007; Kobyliansky et al., 2010).

As larvas de mictofídeos também estão entre as mais abundantes nas assembleias oceânicas de larvas de peixes (Sassa et al., 2004; Castro, 2006; Katsuragawa, 2007; Muhling et al., 2008a). O conhecimento acerca da distribuição dessas larvas, que inclui o padrão de distribuição vertical de várias espécies, é proveniente principalmente dos oceanos Pacífico e Atlântico Norte (Loeb, 1979; Moser \& Smith, 1993; Sassa et al., 2002, 2004, 2007).

$\mathrm{Na}$ maioria dos estudos sobre ictioplâncton realizados na costa brasileira, as larvas de Myctophidae são identificadas em nível taxonômico de família (Bonecker et al., 1992/93; Ekau \& Matsuura, 1996; Ekau et al., 1999; Nogueira et al., 1999; Franco \& Muelbert, 2003; Lopes, 2006). Os poucos trabalhos que identificam essas larvas até espécie, indicam que elas possuem diferentes 
padrões de distribuição espacial e sazonal (Itagaki, 1999; Nonaka et al., 2000; Bonecker \& Castro, 2006; Katsuragawa; 2007; Castro et al., 2010; Bonecker et al., 2012).

Os oceanos não são verticalmente homogêneos e, por esse motivo, a profundidade onde as larvas se encontram pode influenciar sua distribuição horizontal, que está relacionada, entre outros fatores, com as massas de água e os padrões de circulação locais (Doyle et al., 1993; Moser \& Smith, 1993; Gray \& Miskiewicz, 2000; Nonaka et al., 2000; Muhling et al., 2007, 2008; Hollyday et al., 2011). Especialmente para as larvas de Myctophidae, a extensão da migração vertical dos adultos parece influenciar a distribuição de suas larvas (Loeb, 1979; Sassa et al., 2002). Em águas brasileiras, apenas quatro estudos abordam a distribuição vertical de larvas de peixes (Matsuura \& Kitahara, 1995; Lopes, 2006; Goçalo et al., 2011; Bonecker et al., 2012). Dentre esses, dois tratam das larvas de Myctophidae: Lopes (2006), que em nível taxonômico de família verificou a distribuição vertical em cinco estratos até $100 \mathrm{~m}$ de profundidade; e Bonecker et al. (2012), que em nível específico analisaram a distribuição das larvas em diferentes massas de água.

A área de estudo, localizada entre cabo de São Tomé, RJ (22 S) e São Sebastião, SP ( $23^{\circ} 50^{\prime}$ S), possui características dinâmicas típicas de plataformas continentais de latitudes médias (Castro \& Miranda, 1998). A costa sudeste brasileira está sob influência da Corrente do Brasil (CB) e de seus meandramentos (Signorini, 1978; Castro \& Miranda, 1998). A interação entre os regimes de vento, mudança da linha de costa e topografia de fundo modifica o padrão de circulação da $\mathrm{CB}$, acarretando a formação de vórtices e os processos de ressurgência e subsidência costeira ao longo do ano (Rodrigues \& Lorenzzetti, 2001; Castelao \& Barth, 2006; Calado et al., 2010). Esses processos afetam a distribuição e a mistura das massas de água presentes na região (Castro, 1987; Mattos et al., 2004).

Dessa forma, considerando a dinâmica oceanográfica local e a importância ecológica dos mictofídeos, neste estudo serão analisados os padrões de distribuição horizontal e vertical das larvas de Myctophidae em nível específico, 
em relação às massas de água presentes no verão e no inverno, entre cabo de São Tomé e São Sebastião.

\section{Material e métodos}

A metodologia de coleta está descrita na Introdução Geral da presente tese.

Metodologia de laboratório

Em laboratório o ictioplâncton foi totalmente triado $e$ as larvas de Myctophidae foram separadas e identificadas até o nível específico, quando possível, segundo bibliografia especializada (Moser \& Ahlstrom, 1996; Bonecker \& Castro, 2006; Moser \& Watson, 2006).

\section{Análise dos dados}

\section{Massas de água}

Para observar a distribuição das massas de água, foi empregada a análise percentual das três massas presentes na área de estudo: Água Costeira (AC), Água Tropical (AT) e Água Central do Atlântico Sul (ACAS). Essa metodologia fundamenta-se na aplicação do método clássico do triângulo de mistura a fim de estimar a contribuição relativa dos diferentes tipos de água na formação das características físicas das massas de água em estudo. A mistura entre três massas de água, superpostas verticalmente, conduz ao chamado triângulo de mistura, onde os pares extremos delimitam seus vértices. Os índices termohalinos característicos da AC, AT, e ACAS foram identificados diretamente dos diagramas T-S espalhados dos pontos amostrados.

O método para determinação das quantidades percentuais de massas de água (Mamayev, 1975) tem sido bastante aplicado para as águas brasileiras (Castro Filho, 1977; Castro, 1987; Soares \& Möller, 2001; Foloni Neto, 2010). 
Segundo esse método, conhecendo-se a temperatura $T$ e a salinidade $S$ e os índices termohalinos (ou pares extremos) ( $T 1, \mathrm{~S} 1),(\mathrm{T} 2, \mathrm{~S} 2)$ e (T3, S3), é possível determinar as quantidades percentuais $\mathrm{m} 1, \mathrm{~m} 2$ e $\mathrm{m} 3$ destas massas, através da resolução do seguinte sistema linear:

$$
\begin{gathered}
\mathrm{m} 1 \mathrm{~T} 1+\mathrm{m} 2 \mathrm{~T} 2+\mathrm{m} 3 \mathrm{~T} 3=\mathrm{T} \\
\mathrm{m} 1 \mathrm{~S} 1+\mathrm{m} 2 \mathrm{~S} 2+\mathrm{m} 3 \mathrm{~S} 3=\mathrm{S} \\
\mathrm{m} 1+\mathrm{m} 2+\mathrm{m} 3=1
\end{gathered}
$$

A correção dos dados de temperatura e salinidade, a análise dos índices termohalinos, e as rotinas elaboradas para o cálculo da porcentagem de massas de água e confecção dos mapas usando o programa Matlab®, foram realizadas pelo Me. Rafael A. Mattos, do Laboratório de Dinâmica Oceânica do Instituto Oceanográfico USP, coordenado pelo Professor Dr. Ilson Carlos da Silveira.

\section{Volume de água filtrada}

O volume de água filtrada pelas redes foi estimado pela fórmula:

$$
V=a \cdot n \cdot c,
$$

onde:

$\mathrm{V}=$ volume de água filtrada $\left(\mathrm{m}^{3}\right)$;

$a=$ área da boca da rede $\left(m^{2}\right)$;

$\mathrm{n}=$ número de rotações (rot);

$\mathrm{C}=$ fator de aferição do fluxômetro (m/rot), após calibração do aparelho.

\section{Cálculo da densidade e abundância}

O estudo da distribuição horizontal e abundância das larvas foi feito com o material proveniente das coletas com a rede bongô. A abundância foi padronizada em número de larvas por $\mathrm{m}^{2}$ através da fórmula: 


$$
N=(d . x) / V
$$

onde:

$\mathrm{N}=$ abundância de larvas por $\mathrm{m}^{2}$;

$\mathrm{d}=$ profundidade máxima de coleta $(\mathrm{m})$;

$\mathrm{x}=$ número de larvas coletadas em cada amostra;

$V=$ volume de água filtrada $\left(\mathrm{m}^{3}\right)$.

Para o estudo da distribuição vertical, foi analisado o material coletado com a Multinet, e a densidade das larvas foi obtida através da fórmula:

$$
N=x / V .100
$$

onde:

$\mathrm{N}=$ densidade de larvas por $100 \mathrm{~m}^{3}$;

$\mathrm{x}=$ número larvas coletadas em cada amostra;

$V=$ volume de água filtrada $\left(m^{3}\right)$.

Frequência de ocorrência

A frequência de ocorrência das larvas foi obtida através da fórmula:

$$
\mathrm{FO}=(\mathrm{p} / \mathrm{P}) .100
$$

onde:

$\mathrm{FO}=$ frequência de ocorrência (\%);

$\mathrm{p}$ = número de estações positivas para a categoria taxonômica;

$\mathrm{P}=$ número total de estações de coleta.

\section{Análises estatísticas}

O teste não paramétrico Mann-Whitney foi utilizado para testar a diferença de abundância entre os cruzeiros (verão e inverno). As diferenças foram consideradas significativas quando $p<0,05$.

A Análise de Correspondência Canônica (ACC) foi aplicada às amostras coletadas pela rede Multinet durante o verão e o inverno separadamente. $O$ principal objetivo dessa análise foi identificar a influência de variáveis ambientais 
sobre os padrões de composição e abundância das espécies. A ACC é bastante útil para analisar a distribuição de espécies ao longo de gradientes ambientais, pois maximiza a separação de seus nichos (ter Braak, 1986; ter Braak \& Prentice, 1988; ter Braak \& Verdonschot, 1995). A magnitude da correlação e o grau de restrição entre a variável ambiental e um eixo da ACC podem ser extrapolados a partir do comprimento e ângulo do vetor em relação ao eixo. Quanto mais longo e paralelo for o vetor ambiental em relação ao a um eixo, mais forte e mais exclusiva a relação entre a variável e o eixo (ter Braak \& Verdonschot, 1995).

Os táxons com frequência de ocorrência menor do que $1 \%$ foram excluídos das análises. Os valores de abundância foram transformados em $\log (x+1)$ e foi dado peso baixo aos táxons raros. Foram utilizadas três variáveis ambientais (temperatura $\left({ }^{\circ} \mathrm{C}\right)$, salinidade e biovolume $\left(\mathrm{ml}^{\left.-\mathrm{m}^{-3}\right)}\right)$ e três variáveis espaciais (profundidade de coleta, distância da costa e radial). Temperatura, salinidade, biovolume e distância da costa foram expressas como variáveis contínuas. Foram expressas como ordinais as variáveis radial e profundidade de coleta, onde foi utilizado o valor médio de camada. A porcentagem de explicação das variáveis ambientais, espaciais e da interação entre as mesmas foi calculada segundo Borcard et al. (1992). O teste de permutação de Monte Carlo (9999 permutações) foi utilizado, com seleção progressiva das variáveis (forward stepwise) $(\mathrm{p}<0,05)$.

\section{Resultados}

\section{Condições Oceanográficas}

Durante os dois cruzeiros estiveram presentes três massas de água até 200 m de profundidade: Água Costeira (AC), Água Tropical (AT) e Água Central do Atlântico Sul (ACAS). Os diagramas T-S espalhados (Figura 1.1) apresentam distribuição predominantemente triangular, indicando processos de mistura entre essas três massas de água. A AT $\left(23,8^{\circ} \mathrm{C}\right.$ e 37,2$)$ é caracterizada por valores de temperatura superiores a $20^{\circ} \mathrm{C}$ e os maiores valores de salinidade, acima de 36 . A 
presença da $\mathrm{ACAS}\left(13,0^{\circ} \mathrm{C}\right.$ e 35,2$)$ pode ser observada no vértice inferior de cada triângulo. Devido a forte variação sazonal nos valores de salinidade e temperatura da AC associada aos ciclos de chuvas, foram adotados diferentes índices termohalinos para o verão $\left(28,3^{\circ} \mathrm{C}\right.$ e 34,25$)$ e o inverno $\left(22,4^{\circ} \mathrm{C}\right.$ e 33,2$)$.

A distribuição das massas de água apresentou padrões distintos entre os dois cruzeiros. No verão, a ACAS ocupou praticamente toda a extensão da área de estudo junto ao fundo e seu afloramento foi registrado na região costeira entre cabo Frio e o sul da cidade do Rio de Janeiro, com exceção da região de plataforma entre cabo Frio e cabo de São Tomé, onde houve predominância da AT em toda coluna de água analisada, provavelmente associada a um processo de subsidência (Figura 1.2). A AT ocupou a maior parte dos estratos superficiais da plataforma externa, alcançando maior profundidade na coluna de água em direção à região oceânica (Figura 1.2). Sobre a plataforma interna a extensão da sua profundidade foi variável, devido ao processo de mistura entre as massas de água (Figura 1.2). A AC ficou restrita a parte sul da área de estudo, nas proximidades de ilha Grande e ilha de São Sebastião, e apenas aos primeiros 10 $\mathrm{m}$ de profundidade (Figura 1.2).

No inverno não houve afloramento da ACAS, e esta esteve presente junto ao fundo em toda área com exceção da plataforma interna (Figura 1.3.). A AC ocupou grande parte da plataforma interna, chegando a ocupar o fundo, e formando uma extensa área de mistura com a ACAS (Figura 1.3). A AT ocupou toda a superfície da plataforma externa, alcançando a plataforma interna entre cabo Frio e cabo de São Tomé (Figura 1.3). Nota-se que no inverno houve maior proporção de mistura entre as massas de água, tanto na superfície quanto no fundo (Figura 1.3).

Composição taxonômica e abundância

No total 3.539 larvas de Myctophidae foram coletadas, sendo $2.459 \mathrm{com}$ a rede bongô e 1.080 com a rede Multinet, compreendendo 15 gêneros e 19 espécies ou tipos (Tabelas 1.1, 1.2 e 1.3). Dentre esses táxons, ocorreram 
exclusivamente nas coletas realizadas com a rede bongô: Centrobranchus nigroocelatus, Myctophum selenops e Lampadena spp.; e com a rede Multinet: Diogenichthys atlanticus.

Durante o verão, a abundância total foi de 1.050 larvas. $\mathrm{m}^{-2}$ (média=14,6 \pm 20,0 larvas. $\left.\mathrm{m}^{-2}\right)$. Os táxons mais abundantes foram Myctophum affine (27,1\%), Diaphus tipo stubby (17,7\%), Diaphus spp. (12,6\%), Lepidophanes spp. $(7,7 \%)$, Hygophum reinhardti (2,0\%), Diaphus tipo slender (1,9\%), Myctophum obtusirostre $(1,7 \%)$ e Benthosema suborbitale (1,2\%). Outros 13 táxons, representaram menos de $1 \%$ cada; as larvas não identificadas representaram $24,3 \%$ do total. (Tabela 1.1).

No inverno a abundância total de 686,5 larvas. m $^{-2}$ (média=10,4 \pm 13,2 larvas. $\left.\mathrm{m}^{-2}\right)$. Os táxons mais abundantes foram Diaphus spp. (15,1\%), Diaphus tipo stubby (13,5\%), M. affine (9,9\%), Diaphus tipo slender (4,6\%), L. guentheri $(4,5 \%)$, Lepidophanes spp. (2,9\%), Notoscopelus caudispinosus (2,5\%), Hygophum hygomii (2,3\%), Hygophum spp. (2,3\%), Lampanyctus tipo 1 (2,2\%), B. suborbitale $(2,0 \%)$ e Myctophum spp. $(1,4 \%)$. Cada um dos outros nove táxons identificados representaram menos de $1 \%$ da abundância total e as larvas não identificadas $33 \%$.

Comparando os valores de abundância das espécies que ocorreram nos dois cruzeiros (Tabela 1.1), nove táxons foram mais abundantes no verão ( $M$. affine, Diaphus tipo stubby, Lepidophanes spp., H. reinhardtii, M. obtusirostre, Ceratoscopelus spp., N. valdiviae, Nannobrachium sp. e M. asperum,), e cinco táxons foram mais abundantes no inverno (L. gemellari, B. suborbitale, Diaphus tipo slender, H. hygomii, L. guentheri). Entre esses, apenas $M$. affine apresentou diferença significativa $(p<0,05)$ entre os valores de abundância dos dois cruzeiros.

Considerando as duas redes, as espécies $C$. nigroocelatus, D. atlanticus, Lampadena spp. e $M$. selenops foram coletadas exclusivamente no verão, enquanto, Lampanyctus tipo 1, Lampanyctus tipo 2, e N. causdipinosus somente no inverno (Tabelas 1.1, 1.2 e 1.3). 
Distribuição horizontal

Myctophum affine esteve amplamente distribuída por toda a área de estudo. Foi mais frequente a abundante durante o verão (Tabela 1.1), com diferença significativa entre os valores de abundância dos dois cruzeiros $(p=0,0007)$. Embora mais frequente e abundante além da isóbata de $100 \mathrm{~m}$, também ocorreu na região costeira entre cabo de São Tomé e cabo Frio durante o verão (Figura 1.4A), e entre ilha Grande e Angra dos Reis durante o inverno (Figura 1.4B).

Diaphus tipo stubby foi mais frequente e abundante no verão (Tabela 1.1), no entanto não houve diferença significativa nos valores de abundância entre os dois cruzeiros. No verão, com exceção de uma estação ao largo do cabo de São Tomé, a espécie distribuiu-se por toda área ao sul do cabo Frio, além da isóbata de $100 \mathrm{~m}_{-}$No inverno sua área de ocorrência foi mais ampla, atingindo a área ao norte do cabo Frio e a plataforma interna (Figuras 1.5A e B).

Diaphus tipo slender, foi mais frequente e abundante durante o inverno, mas não apresentou diferença significativa entre os valores de abundância dos cruzeiros. A espécie apresentou distribuição semelhante a Diaphus tipo stubby, mas de modo geral, em região mais afastada da costa (Figuras 1.6A e B).

Lepidophanes guentheri ocorreu apenas no talude no verão e também sobre a plataforma no inverno (Figuras 1.7A e B). As larvas de Lepidophanes spp. ocorreram durante os dois períodos, em toda área de estudo além da isóbata de $100 \mathrm{~m}$ (Figuras 1.8A e B). A menor abundância de $L$. guentheri no verão pode ter sido um artefato, pois a maioria das larvas desse gênero não foram identificadas até espécie.

Benthosema suborbitale foi mais frequente no inverno, embora os valores de abundância média tenham sido muito próximos nos dois cruzeiros (Tabela 1.1). No verão, a espécie ocorreu somente além da isóbata de $100 \mathrm{~m}$, com maior abundância no talude (Figura 1.9A), e no inverno ocorreu também na plataforma interna próxima ao cabo Frio (Figura 1.9B).

Hygophum hygomii ocorreu apenas em duas estações, no talude, durante 0 verão (Figura 1.10A), e foi mais frequente e abundante no inverno, quando 
ocorreu sobre a plataforma externa e talude (Figura 1.10B). Foi coletada apenas ao sul do Cabo Frio nos dois cruzeiros.

Hygophum reinhardtii no verão, quando foi mais abundante, foi capturada em toda a área de estudo além da isóbata de $100 \mathrm{~m}$ (Figura 1.11A), e no inverno foi capturada no talude $e_{2}$ próximo ao cabo Frio, na região costeira (Figura 1.11B).

Myctophum obtusirostre, foi mais frequente e abundante no verão (Tabela 1.1), embora a diferença entre os cruzeiros não tenha sido significativa. No verão ocorreu em uma estação costeira próxima ao cabo de São Tomé e além da isóbata de $100 \mathrm{~m}$, com maior abundância no talude (Figura 1.12A). No inverno ocorreu somente no talude e apenas em duas estações (Figura 1.12B).

Ceratoscopelus spp. foi coletada apenas em uma estação no talude durante o verão (Figura 1.13A). No inverno foi mais frequente, ocorrendo desde o talude até a plataforma interna, onde foi coletada nas proximidades de Ubatuba Figura 1.13B).

Notolychnus valdiviae foi coletada apenas sobre o talude, além da isóbata de $500 \mathrm{~m}$ nos dois cruzeiros, com apenas uma ocorrência no inverno (Figura 1.14A e B). Nannobrachium sp. ocorreu em uma estação próxima a isóbata de $2.500 \mathrm{~m}$ no verão e em uma estação na isóbata de $1.000 \mathrm{~m}$ no inverno (Figura $1.15 \mathrm{~A}$ e B). Myctophum asperum ocorreu nos dois cruzeiros apenas no talude (Figura 1.15A e B).

Myctophum selenops foi registrada somente no verão, em apenas duas estações, uma na plataforma externa, na altura do cabo Frio e outra próxima a isóbata de $1.000 \mathrm{~m}$, no sul da área de estudo (Figura 1.15A).

As espécies com apenas uma ocorrência, registrada durante o verão, foram: C. nigroocelatus, próxima a isóbata de $1.500 \mathrm{~m}$ ao largo do cabo Frio; Lampadena sp. além da isóbata de1.000 m no sul da área de estudo e Myctophum nitidulum, além da isóbata de $500 \mathrm{~m}$, ao sul do Rio de Janeiro(Figura 1.15A).

As larvas do gênero Lampanyctus ocorreram somente no inverno. Lampanyctus tipo 1 ocorreu além da isóbata de $100 \mathrm{~m}$, com maior abundância no talude (Figura 1.16A), e Lampanyctus tipo 2 ocorreu no talude, além da isóbata de $500 \mathrm{~m}$ (Figura 1.16B). 
Notoscopelus caudispinosus ocorreu exclusivamente no inverno, além da isóbata de $100 \mathrm{~m}$, com maior abundância a partir da isóbata de $500 \mathrm{~m}$. Houve apenas uma ocorrência na plataforma interna, em frente à ilha grande e nenhuma ao norte do cabo Frio (Figura 1.17).

As larvas de Symbolophorus rufinus também apenas no inverno, além da isóbata de $500 \mathrm{~m}$ (Figura 1.18).

Distribuição vertical (rede Multinet)

\section{Verão}

No verão, foram coletadas 739 larvas, com uma densidade total de 3.605 larvas. $100 \mathrm{~m}^{3}$. A maior densidade total foi observada na camada entre $20-40 \mathrm{~m}$ de profundidade (1.107 larvas. $100 \mathrm{~m}^{3}$ ) e a menor na camada entre $80-100 \mathrm{~m}$ (449 larvas. $100 \mathrm{~m}^{3}$ ). As espécies mais abundantes foram $M$. affine, Diaphus tipo stubby, Lepidophanes spp. Diaphus spp., M. obtusirostre , H. reinhardti. Cada um dos demais táxons representou menos de $1 \%$ da densidade total (Tabela 1.2).

Segundo o teste de Monte Carlo, foram consideradas significativas $(p<0,05)$ as variáveis ambientais: salinidade e temperatura, e as variáveis espaciais: profundidade de coleta e radiais (Tabela 1.4). A salinidade não foi significativa sob influência das variáveis espaciais e a distância da costa não foi considerada significativa sob influência das variáveis ambientais.

As variáveis ambientais e espaciais, somadas, explicaram aproximadamente $25 \%$ da variabilidade na abundância das larvas de Myctophidae durante o verão. A importância relativa dos processos que controlam essa variação pode ser definida da seguinte forma: ambiente 5,9\%; espaço 12,7\%; ambiente espacialmente estruturado 6,1\% (Tabela 1.5).

Os autovalores, que medem a importância dos eixos da ACC, variaram entre 0,289 (eixo 1) e 0,012 (eixo 4). No entanto, a correlação espécie-ambiente foi mais alta, variando entre 0,643 (eixo 1) e 0,329 (eixo 4) (Tabela 1.6). A porcentagem de variância acumulada foi de $23 \%$ na abundância das espécies e de $100 \%$ na relação espécie ambiente para os quatro primeiros eixos da ACC. 
Como os dois primeiros eixos representaram $91 \%$ da porcentagem da variância acumulada na relação espécie ambiente, e aproximadamente $21 \%$ da abundância das espécies, somente esses eixos serão analisados (Tabela 1.6).

A temperatura e a salinidade apresentaram maior correlação com o eixo 1, representando um gradiente ambiental, enquanto a profundidade de coleta e as radiais foram mais correlacionadas com o eixo 2, representando um gradiente espacial (Figura 1.19). Os vetores de salinidade e temperatura apresentaram praticamente o mesmo comprimento. No entanto, o comprimento do vetor profundidade de coleta foi maior do que o do vetor radial, mostrando que a profundidade de coleta apresenta maior influência sobre a distribuição das amostras, conforme pode ser observado na Figura 19a.

A relação dos pares de valores de salinidade e temperatura pode ser associada às massas de água. Altos valores de salinidade e temperatura estão associados à alta porcentagem de $\mathrm{AT}$, baixos valores de salinidade e temperatura à alta porcentagem de ACAS e altas temperaturas com baixa salinidade à presença de AC. A maior mistura das massas de água é representada por valores intermediários de salinidade e temperatura (Figura 1.19B).

O diagrama de ordenação da ACC de verão mostra que as larvas de Myctophidae possuem padrões distintos de distribuição ao longo dos gradientes analisados (Figura 1.19A).

As larvas de $S$. rufinus e $N$. valdiviae foram mais abundantes nas maiores profundidades de coleta, nas radiais mais ao norte, relacionadas com os valores mais altos de temperatura e salinidade (Figura 1.19A). Essas espécies ocorreram somente entre 60-100 m de profundidade, onde a porcentagem da massa de água AT foi muito alta (Figuras 1.20 e 1.21).

Em outro grupo, formado por L. gemellarii, H. reinhardtii, B. suborbitale e $M$. obtusirostre, as larvas foram mais abundantes entre as profundidades altas e intermediárias, também relacionadas com altos valores de temperatura e salinidade, indicando alta porcentagem de AT (Figura 1.19A). As larvas das duas primeiras espécies foram abundantes nas radiais mais ao norte e as duas últimas nas radiais mais ao sul. $L$. gemellarii foi coletada entre 40-100 m de profundidade, 
com maior frequência e abundância média entre 80-100 m (Figura 1.22); $H$. reinhardtii ocorreu desde a superfície até $100 \mathrm{~m}$ de profundidade, com maior frequência e abundância média entre $60-80 \mathrm{~m}$ (Figura 1.23); $B$. suborbitale foi coletada entre 20 e $100 \mathrm{~m}$ de profundidade, com maior frequência entre $40-60 \mathrm{~m}$ e maior abundância média entre 60-80 m (Figura 1.24) e $M$. obtusirostre ocorreu entre 20-80 m de profundidade, e foi mais frequente e abundante entre 40-60 m (Figura 1.25).

Diaphus tipo stubby, Diaphus tipo slender e L. guentheri foram mais abundantes nas menores profundidades de coleta, associadas a valores intermediários de temperatura e salinidade baixa, que indicam maior porcentagem de mistura entre as massas de água (Figura 1.19A). Diaphus tipo stubby foi capturada desde a superfície até $100 \mathrm{~m}$ de profundidade, com maior frequência e densidade média entre 0-20 m (Figura 1.26). Diaphus tipo slender, ocorreu entre 0-60 m de profundidade, com maior frequência de ocorrência entre 40-60 m e densidade média entre 20-40 m (Figura 1.27). Lepidophanes guentheri ocorreu entre a superfície e $60 \mathrm{~m}$ de profundidade e foi mais frequente entre $0-40$, com maior densidade média entre 20-40 m (Figura 1.28).

Myctophum affine foi mais abundante nas profundidades altas $\mathrm{e}$ intermediárias, nas radiais mais ao norte, associadas a baixos valores de temperatura e salinidade, indicando que essa espécie foi mais abundante em regiões com alta porcentagem de mistura entre as massas de água AT e ACAS (Figura 19A). Foi coletada entre a superfície e $100 \mathrm{~m}$ de profundidade, com frequência de ocorrência elevada entre $60-80 \mathrm{~m}$ e pouca variação na densidade média entre 20-100 m de profundidade (Figura 1.29).

Outras espécies foram coletadas em uma única amostra, e não entraram nas análises: Ceratoscopelus sp., entre 0-20 m (Figura 1.30), D. atlanticus entre 80-100 m (Figura 1.31), Nannobrachium sp. entre 60-80 m (Figura 1.32) e $M$. asperum entre 60-80 $\mathrm{m}$ de profundidade (Figura 1.33). Todas elas coletadas no norte da área de estudo, em regiões com alta porcentagem de AT. 


\section{Inverno}

No inverno foram coletadas 341 larvas, com uma densidade total de $1.087,3$ larvas. $100 \mathrm{~m}^{-3}$. A maior densidade total foi observada na camada entre $20-40 \mathrm{~m}$ de profundidade (360 larvas. $100 \mathrm{~m}^{-3}$ ) e a menor, entre 80-100 m (32 larvas.100 $\mathrm{m}^{-3}$ ). As espécies mais abundantes foram Diaphus tipo stubby, M. affine, $H$. hygomii, $L$. guentheri, Hygophum spp., Diaphus spp., S. rufinus, Diaphus tipo slender, $B$. suborbitale, Lampanyctus tipo $1, H$. reinhardti, M. obtusirostre e $N$. caudispinosus. As outras espécies representaram menos de 1,0\% cada (Tabela 1.3).

Nesse cruzeiro somente as variáveis espaciais, distância da costa e profundidade de coleta, foram significativas $(p<0,05)$, segundo o teste de Monte Carlo (Tabela 1.7). Essas variáveis explicaram 12,1\% da variação das espécies. Analisando as variáveis ambientais sem o efeito das variáveis espaciais, somente salinidade foi considerada significativa $(p<0,05)$. A importância relativa dos processos que controlam essa variação pode ser definida da seguinte forma: espaço $8,3 \%$ e ambiente espacialmente estruturado 3,8\% (Tabela 1.8). As variáveis ambientais, sem o efeito espacial, não explicaram nada sobre a variação da densidade das larvas de Myctophidae durante o inverno (Tabela 1.8).

Os autovalores, variaram entre 0,267 (eixo 1) e 0,682 (eixo 4) (Tabela 1.9). A correlação espécie-ambiente foi de 0,659 no eixo 1 e zero nos eixos 3 e 4 . A porcentagem de variância acumulada nos quatro primeiros eixos da ACC foi de $36 \%$ na abundância das espécies e de $100 \%$ na relação espécie ambiente (Tabela 1.9). Como o valor máximo da porcentagem de variância acumulada na relação espécie ambiente foi atingido nos dois primeiros eixos, somente esses serão interpretados, embora a variância acumulada da abundância das espécies nesses dois eixos tenha sido de apenas $8,8 \%$ (Tabela 1.9).

A distância da costa e a profundidade de coleta estiveram fortemente correlacionadas com os eixos 1 e 2, respectivamente (Figura 1.34). Assim, o eixo 1 pode ser interpretado como um gradiente horizontal e o eixo 2 como um gradiente vertical. As amostras a direita do diagrama, mais distantes da costa, apresentam as maiores porcentagens de AT, e as amostras do centro a esquerda maior mistura entre as massas de água (Figura 1.34B). 
Nesse período, no diagrama de ACC, as larvas de Myctophidae apresentaram menor distância espacial em relação umas às outras (Figura 1.34A).

As larvas de B. suborbitale, Lampanyctus tipo 2 e $S$. rufinus foram mais abundantes nas maiores profundidades de coleta, em regiões intermediárias de distância da costa (Figura 18). Benthosema suborbitale foi coletada entre 60 e 100 $\mathrm{m}$ de profundidade, com maior frequência e densidade média entre 60-80 m (Figura 1.35); Lampanyctus tipo 2 foi capturada apenas na radial mais ao sul, nos estratos de 0-20 m e de 80-100 m (Figura 1.36), com maior densidade média nesse último estrato; Symbolophorus rufinus ocorreu entre 20-80 m, com maior frequência e densidade média entre 60-80 m (Figura 1.37).

Myctophum affine e Diaphus tipo stubby foram mais abundantes nas regiões intermediárias de profundidade de coleta e distância da costa (Figura 1.34A). As duas espécies foram capturadas desde a superfície até $100 \mathrm{~m}$ de profundidade; $M$. affine foi mais frequente e abundante entre 40-60 m (Figura 1.38) e Diaphus tipo stubby apresentou maior frequência entre 60-80 $\mathrm{m}$ e maior densidade média entre 40-60 m (Figura 1.39).

Myctophum obtusirostre, $\mathrm{H}$. renhardtii e $\mathrm{H}$. hygomii foram mais abundantes nas profundidades de coleta intermediárias, em regiões mais distantes da costa (Figura 1.34A). Myctophum obtusirostre ocorreu entre 20-80 m de profundidade, com maior frequência e abundância entre 40-60 m (Figura 1.40). Hygophum hygomii ocorreu entre a superfície e $100 \mathrm{~m}$ de profundidade, com maior frequência e densidade média entre 20-60 m (Figura 1.41). Hygophum reinhardtii ocorreu entre a superfície e $80 \mathrm{~m}$ de profundidade, com maior frequência de ocorrência na camada entre 0-20 m e maior densidade média entre 60-80 m (Figura 1.42).

Lampanyctus tipo 1, M. nitidulum, Diaphus tipo slender e N. caudispinosus foram mais abundantes em baixas profundidades de coleta, em regiões intermediárias e distantes em relação à costa (Figura 1.34A). Lampanyctus tipo 1 foi coletada entre a superfície e $60 \mathrm{~m}$ de profundidade, sendo mais frequente entre 0-20 m e mais abundante entre 40-60 m (Figura 1.43); M. nitidulum ocorreu entre 20-40 m (Figura 1.44); Diaphus tipo slender ocorreu desde a superfície até $80 \mathrm{~m}$ de profundidade, com maior frequência e abundância média entre 0-20 m de 
profundidade (Figura 1.45); Notoscopelus caudispinosus ocorreu apenas entre 040 m, com maior frequência e abundância entre 0-20 m (Figura 1.46).

Lepidophanes guentheri foi mais abundante nas menores profundidades, em regiões intermediárias de distância da costa (Figura 1.34A). Foi coletada entre a superfície e $60 \mathrm{~m}$ de profundidade, sendo mais frequente e abundante entre 0 $20 \mathrm{~m}$ (Figura 1.47).

\section{Discussão}

\section{Composição taxonômica}

O número de espécies de Myctophidae encontradas no presente trabalho (19) é intermediário ao observado em outros estudos de larvas de peixes na costa brasileira. Foram identificadas oito espécies na região de Abrolhos (Nonaka et al., 2000), 16 espécies na bacia de Campos (Bonecker et al., 2012), 18 táxons, incluído espécie e gênero, entre cabo Frio e cabo de Santa Marta Grande (Katsuragawa, 2007) e 27 espécies, incluindo os estágios de larva e juvenil, entre o rio Real e o cabo de São Tomé (Castro et al., 2010). O gênero Myctophum apresentou o maior número de espécies entre as larvas identificadas.

Devido à presença de no mínimo 20 espécies de Diaphus e 10 espécies de Lampanyctus na costa brasileira (Nafpaktitis et al., 1977; Santos \& Figueiredo, 2008; Braga et al., 2008) e a carência de descrição das fases iniciais do desenvolvimento dessas espécies, não foi possível distinguir esses gêneros até o nível específico. As larvas do gênero Diaphus foram separadas em tipo "stubby" (corpo alto e apenas um ou dois pigmentos ventrais no pedúnculo caudal) e tipo "slender" (corpo mais alongado e com uma série de pigmentos ventrais ao longo do pedúnculo caudal) (Moser\&Ahsltrom, 1974; Ozawa, 1986; Sassa, 2003). As larvas do tipo "stubby" pertencem ao grupo de Diaphus que não apresenta fotóforo supranasal (SNO), enquanto as larvas do tipo "slender" pertencem ao grupo que desenvolve o fotóforo SNO. No entanto, algumas larvas de Diaphus não apresentaram um padrão de pigmentação bem claro, pois estavam muito danificadas e não puderam ser identificadas como um desses dois tipos. 
Comparando com a composição e distribuição dos indivíduos adultos, a maioria das larvas de Diaphus tipo stubby podem ser $D$. garmani e $D$. dumerilli, pois essas são as espécies desse grupo mais abundantes na área de estudo (Figueiredo et al., 2002; Bernardes et al., 2005; Braga et al., 2007). As larvas de Lampanyctus foram separadas em Lampanyctus tipo 1 e Lampanyctus tipo 2. Esses dois tipos mostram diferenças morfológicas bastante distintas indicando que podem ser duas espécies diferentes, ou pelo menos que pertencem a dois grupos distintos assim como as larvas do gênero Diaphus.

Os gêneros Ceratoscopelus, Lampadena e Nannobrachium possuem um menor número de espécies, mas as larvas apresentaram poucas características para sua identificação em nível específico.

Muitas larvas não foram identificadas devido ao estágio de desenvolvimento muito inicial, à falta de pigmentos e/ou por estarem danificadas, impedindo a observação de características morfométricas. A maioria dessas larvas pode pertencer aos gêneros Lepidophanes, Ceratoscoplelus e/ou Diaphus que possuem formato do corpo muito semelhante, e por isso torna a identificação praticamente impossível sem, pelo menos, a presença dos pigmentos.

\section{Distribuição horizontal}

As larvas de Myctophidae são consideradas membros permanentes das assembleias oceânicas de larvas de peixes (Doyle et al., 1993; Nonaka et al., 2000; Franco \& Muelbert, 2003; Katsuragawa, 2007; Castro et al., 2010). Neste estudo elas distribuíram-se predominantemente pelo talude e plataforma externa, mas a amplitude de ocorrência sobre a plataforma variou de acordo com a espécie e com os padrões de distribuição das massas de água. Os dados das redes bongô e Multinet mostraram que a distribuição dessas larvas sobre a plataforma seguiu o mesmo padrão de intrusão da AT. No verão, a intrusão da ACAS foi mais intensa, enquanto a extensão da AT ficou limitada à plataforma externa, impedindo o transporte das larvas para áreas mais internas. Porém, a passagem de uma frente fria entre cabo Frio e cabo de São Tomé provocou um processo de subsidência da AT nessa região durante esse período de amostragem (Mattos et al., 2004), onde 
foram encontradas larvas de $M$. affine e $M$. obtusirostre na plataforma interna. No inverno, com o predomínio de processos mais favoráveis à subsidência (Castelao et al., 2006), foi observada a intrusão da AT em diversas áreas da plataforma interna. Nesse período, foram coletadas larvas de diversas espécies de Myctophidae na região costeira, entre cabo Frio e cabo de São Tomé e nas proximidades de Ubatuba. Katsuragawa (2007) também observou diferenças na distribuição horizontal das larvas de Myctophidae na costa sudeste do Brasil, entre cabo Frio e cabo de Santa Marta Grande, onde M. affine, por exemplo, também se distribuiu amplamente, aproximando-se da costa durante a primavera ao largo de cabo Frio, enquanto outras espécies como L. guentheri e Lampanyctus spp. ampliaram sua distribuição sobre a plataforma interna durante o outono. A ocorrência de larvas de Myctophidae na plataforma interna na costa sudeste e sul do Brasil foi previamente relacionada à intrusão da AT em diversos estudos (Itagaki, 1999; Franco \& Muelbert, 2003; Lopes, 2006; Katsuragawa, 2007). A presença da AT sobre a plataforma ocorre através de meandramentos e vórtices da Corrente do Brasil, cujas causas têm sido amplamente investigadas (Castelao et al., 2006). De qualquer modo, esses têm sido apontados como os principais mecanismos de transporte das larvas mesopelágicas para áreas de plataforma. Franco et al. (2006) destacam que os vórtices que ocorrem na plataforma concentram as larvas de peixes mesopelágicas em sua periferia, aumentando a abundância de larvas nessa região. Katsuragawa (2007) concluiu que os vórtices também seriam responsáveis pelo retorno das larvas mesopelágicas para a região oceânica, pois seu tempo de duração permitiria que as larvas se desenvolvessem sobre a plataforma antes que retornassem àquela região.

A distribuição das larvas também pode estar relacionada com o habitat dos adultos. Os mictofídeos são classificados de acordo com seu habitat em dois grandes grupos: oceânico (ampla distribuição, principalmente na região oceânica) e pseudo-oceânico (espécies que ocorrem exclusivamente na plataforma, no talude e nas proximidades de ilhas oceânicas, e.g. D. garmani) (Hulley, 1981). Na costa brasileira os mictofídeos oceânicos, na fase adulta, podem estender sua ocorrência desde a região oceânica até a plataforma externa, até o talude, ou 
habitar exclusivamente a região oceânica (Santos, 2003). A maioria das espécies encontradas nesse estudo possui ocorrência registrada sobre o talude e a plataforma na fase adulta, e.g. L. guentheri e M. affine, com ampla distribuição pela área de estudo. As espécies exclusivamente oceânicas foram raras, como $D$. atlanticus e $C$. nigroocelatus, cujas larvas ocorreram somente além da isóbata de $1.500 \mathrm{~m}$ e haviam sido registradas previamente nas proximidades dos montes submarinos Vitória e Davis $\left(20^{\circ} S\right.$ ) (Castro et al., 2010). Coletas de peixes mesopelágicos adultos nas cordilheiras Meso-Atlânticas e Walvis, no sul do Atlântico, mostraram que $D$. atlanticus é uma das espécies dominantes, (Kobyliansky et al., 2010). Assim, supõe-se que essas espécies consideradas raras devam mais ser abundantes nas regiões mais afastadas do talude, pois a região estudada abrange apenas a borda da sua área de distribuição.

$\mathrm{Na}$ Corrente de Benguela as larvas de espécies mesopelágicas, incluindo os mictofídeos, que ocorrem sobre a plataforma são mais abundantes durante os períodos de ressurgência intensa, enquanto as que se limitam ao talude são relativamente pouco abundantes e ocorrem durante todo o ano (Olivar \& Shelton, 1993). Na costa brasileira, a espécie com distribuição mais ampla pela plataforma foi $M$. affine, que também foi significativamente mais abundante durante o verão, período em que a ressurgência da ACAS é mais frequente e intensa. Outras espécies não ficaram restritas ao talude como no caso da costa da África, mas sua distribuição sobre a plataforma foi menos ampla e não apresentaram diferença significativa entre os períodos de coleta. A maior abundância de larvas de $M$. affine durante o verão ou primavera e a baixa diferença sazonal na abundância de outros mictofídeos já foi registrada em outras áreas da costa brasileira (Nonaka et al., 2000; Katsuragawa, 2007; Castro et al., 2010).

No verão, além da aglomeração de biomassa de zooplâncton na área costeira, devido ao enriquecimento das águas superficiais pela ACAS, manchas de zooplâncton também ocorrem na plataforma, entre as isóbatas de 100 e 200 m, e próximo ao talude (Lopes et al., 2006). Portanto, as espécies cujas larvas são mais abundantes sobre a plataforma devem desovar mais intensamente durante 0 verão, coincidindo com o pico de produção zooplanctônica (Lopes, 2006; Lopes et 
al., 2006; Goçalo, 2008). A sincronização da desova e a produção de zooplâncton são de extrema importância para a alimentação e consequentemente para a sobrevivência das larvas, e é a base da hipótese "match-mismatch" de Cushing (1974), segundo a qual, a mortalidade é mais elevada quando o alimento não está disponível, principalmente nos primeiros dias em que a larva passa a se alimentar de maneira exógena. Por outro lado, a desova durante o ano todo, comum entre as espécies oceânicas, deve refletir a relativa estabilidade dessa região (Doyle et al., 1993), que sofre menor variação sazonal tanto das condições oceanográficas como da biomassa de zooplâncton (Lopes et al., 2006; Goçalo, 2008). Essa biomassa diminui da região costeira em direção à oceânica (Lopes et al., 2006), mas mesmo com baixas densidades de presas, as larvas de peixes apresentam altas taxas de alimentação, devido à microturbulência (Rothschild \& Osborn, 1988; Dower et al., 1997) e à distribuição agregada do plâncton, que elevam a taxa de encontro com a presa e garantem sua sobrevivência.

Doyle et al. (1993) apontam para uma co-evolução das estratégias reprodutivas dos peixes associadas à complexidade do ambiente marinho, que estrutura a distribuição do ictioplâncton. Desse modo, a segregação espacial das larvas e a desova durante o inverno, ou durante todo o ano, observada na maioria das espécies de Myctophidae, podem ser derivadas de um processo evolutivo para evitar a competição com as espécies que desovam intensamente durante o verão.

\section{Distribuição vertical}

As larvas de Myctophidae foram coletadas em toda a coluna d'água amostrada, com maiores abundâncias nos estratos de 20-40 m e menores entre 80-100 m tanto no verão quanto no inverno. Em outras áreas, onde as coletas incluíram estratos mais profundos, as larvas dessa família também se concentraram nos primeiros 100 m da coluna d'água (Ahlstrom, 1959; Loeb, 1979; Sassa et al., 2002; Bonecker et al., 2012), indicando que essa é sua faixa preferencial de distribuição.

A família Myctophidae é composta por duas subfamílias, Lampanyctinae e 
Myctophinae, para as quais são observados distintos padrões de distribuição vertical no Oceano Pacífico: as larvas das espécies de Lampanyctinae se concentram nos primeiros $50 \mathrm{~m}$, enquanto as de Myctophinae são mais abundantes abaixo dessa profundidade (Ahlstrom, 1959; Moser \& Smith, 1993; Sassa et al., 2002; Sassa et al., 2004b). Entretanto, no presente estudo esse padrão de distribuição vertical das duas subfamílias não foi tão evidente e variou entre os dois períodos de coleta. Durante o verão o gráfico da ACC mostrou que as larvas de Myctophinae estiveram relacionadas com profundidades de coleta maiores do que as de Lampanyctinae, com exceção de $N$. valdiviae e L. gemellari, que pertencem a essa última subfamília, mas ocorreram somente abaixo de $60 \mathrm{~m}$ de profundidade. No inverno, embora B. suborbitale (Myctophinae) e L. guentheri e $N$. caudispinosus (Lampanyctinae) tenham ocorrido dentro do padrão de distribuição vertical esperado, não houve separação evidente entre as duas subfamílias em relação à profundidade de ocorrência. No geral, as espécies de Myctophinae reduziram sua densidade relativa, ou até mesmo estiveram ausentes, entre 80-100 m, enquanto elevaram sua densidade relativa entre 20-40 m. Por outro lado, dentre os Lampanyctinae, houve um aumento da densidade relativa de Diaphus tipo stubby e Lampanyctus tipo 2 nas camadas mais profundas. Assim, a maioria das espécies das duas subfamílias esteve associada com profundidades intermediárias no inverno, apresentando menor distância em relação umas as outras no diagrama da ACC.

Os estudos que retratam o padrão geral da distribuição vertical das larvas de Myctophidae foram realizados, em apenas uma época do ano, no Giro Central do Pacífico Norte e na Corrente de Kuroshio, em regiões que apresentam menor variação das características físicas quando comparadas com a do atual trabalho. O Giro Central do Pacífico, por exemplo, não apresenta variação horizontal nas características físicas e a profundidade da camada de mistura é constante durante o verão (Loeb, 1979). Por outro lado, a costa sudeste do Brasil engloba a interação entre três massas de água desde a plataforma interna até o talude, ao longo de um gradiente latitudinal com diferentes características oceanográficas, que também varia sazonalmente. Desse modo, é esperado que ocorra variação ao 
longo do tempo e do espaço na distribuição vertical das larvas, pois essa é afetada pelas condições oceanográficas, como temperatura e profundidade da camada de mistura, que variam espacial e temporalmente (Ahlstrom 1959). No presente estudo foi possível verificar que a interação entre as massas de água afetou a distribuição vertical das espécies nos dois períodos estudados. Considerando que muitas espécies estão relacionadas à maior proporção de AT, a extensão da distribuição vertical dessas larvas pode diminuir em locais onde há maior proporção de AC ou ACAS. Esse fato foi corroborado pelo baixo número de larvas coletadas nos estratos com maiores porcentagens dessas massas de água. Devido às características oceanográficas do estrato amostrado (até $100 \mathrm{~m}$ de profundidade), poucas coletas foram realizadas abaixo da camada de mistura entre a AT e a ACAS, mas, na Bacia de Campos, a ocorrência de larvas na ACAS e nas massas de água subjacentes também foi baixa (Bonecker et al., 2012). $\mathrm{Na}$ costa da Califórnia as larvas distribuíram-se acima da termoclina, predominantemente na porção superior camada de mistura (Ahlstrom 1959). Embora não houvesse um CTD acoplado a rede, o que poderia prejudicar a precisão dos limites dos estratos amostrados, a frequência de ocorrência e os centros de distribuição das larvas das diferentes espécies foram bastante consistentes em relação à sua ocorrência na $\mathrm{AT}$, e na mistura entre as massas de água. No entanto, para verificar o centro de distribuição de algumas espécies raras, principalmente as que ocorreram somente entre 80-100 m de profundidade, seria necessário realizar coletas em estratos mais profundos. Na corrente de Kuroshio, por exemplo, D. atlanticus localiza-se entre 75-150 m de profundidade (Sassa et al., 2002), indicando que deve ser mais abundante em profundidades maiores do que as amostradas no presente estudo.

O padrão de distribuição vertical das larvas é oposto ao dos adultos nas camadas superiores durante a noite, para a maioria das espécies de Myctophidae (Loeb, 1979; Sassa et al., 2002). Moser \& Smith (1993) sugerem que essa segregação de habitat seja proveniente de um processo evolutivo para evitar a mortalidade por canibalismo. Essa segregação foi notada, principalmente no verão, em espécies cujas larvas e adultos ocorrem na mesma área, e, portanto 
podem compartilhar o mesmo habitat. Por exemplo, as larvas de L. guentheri e Diaphus tipo stubby (Diaphus c.f. garmani), cujos adultos ocorrem sobre a plataforma (Santos, 2003), se concentraram nos estratos mais superficiais, enquanto as larvas de $S$. rufinus e $N$. valdiviae, cujos adultos ocorrem a partir do talude e região oceânica respectivamente (Santos, 2003), foram coletadas em maiores profundidades. A existência de diferença horizontal na distribuição entre larvas e adultos também deve ser considerada. Desse modo não haveria risco de canibalismo, independentemente da posição da larva na coluna d'água. Esse pode ser o caso de $M$. affine, cujas larvas distribuíram-se amplamente em todos os estratos de profundidade sobre a plataforma, e cujos adultos são registrados somente a partir do talude (Santos, 2003).

A variação na distribuição das espécies também pode estar relacionada com a morfologia (Moser \& Smith, 1993): as larvas de Myctophinae, que normalmente ocorrem em maiores profundidades, além de corpo mais robusto, possuem olhos elípticos, enquanto a maioria das larvas de Lampanyctinae, que ocorrem em estratos mais superficiais, possuem olhos arredondados (Moser \& Ahlstrom, 1974). Considera-se que os olhos elípticos sejam uma adaptação à região mais profunda, pois possuem maior capacidade de rotação, o que permite um maior campo de visão em relação aos olhos arredondados, e consequentemente, maior chance de localizar presas (Weihs \& Moser, 1981). A espécie $N$. valdiviae, apesar de pertencer a Lampanyctinae, possui olhos elípticos na fase larval, tendo sido coletada abaixo de $60 \mathrm{~m}$ de profundidade nesse e em outros estudos (Loeb, 1979; Sassa et al., 2002). As larvas de L. gemellarii, outra espécie dessa subfamília, que nesse estudo foi mais abundante entre $60-100 \mathrm{~m}$ de profundidade, possui corpo robusto e olhos classificados como levemente ovais (Moser \& Watson, 2006). As larvas de Myctophidae também podem apresentar outras especializações para capturar presas em condições de pouca luz, como Benthosema glaciale e Myctophum punctatum, cuja retina é constituída por células bastonetes, mais sensíveis à luz (Sabastés et al., 2003).

O biovolume de plâncton, que poderia ser um indicativo da quantidade disponível de presas, engloba diversos organismos, mas nem todos fazem parte 
da dieta das larvas, como salpas e doliolídeos, que representaram boa parte do zooplâncton durante o verão (Oliveira, 2006). Essa variável teve distribuição vertical aproximadamente homogênea, com exceção da área mais costeira entre os cabos Frio e de São Tomé no verão (Goçalo, 2006). Além disso, foi detectada uma uniformidade na distribuição vertical de copépodes e ostracodas (Oliveira, 2009), consideradas possíveis presas das larvas de Myctophidae (Conley \& Hopkins, 2004). Desse modo, a uniformidade na distribuição do biovolume fez com que essa variável não contribuísse para a explicação da distribuição das larvas dos mictofídeos durante os períodos estudados.

A baixa explicação das variáveis sobre a distribuição das larvas de Myctophidae demonstra a complexidade em avaliar a distribuição desse grupo. Diversos fatores que não podem ser medidos diretamente também afetam a distribuição das espécies, incluindo local de desova dos adultos, predação, comportamento, que está muito ligado à morfologia, disponibilidade de alimento, velocidade das correntes de transporte, entre outros (Muhling \& Beckley, 2007).

Todavia, este estudo mostra que os padrões de distribuição vertical e horizontal das espécies de Myctophidae variam de acordo com as condições oceanográficas locais. A extensão da distribuição dessas larvas sobre a plataforma está associada aos processos de intrusão da AT e de ressurgência da ACAS, sendo que a maior intensidade do primeiro aumenta a distribuição das larvas sobre a plataforma, enquanto o segundo diminui a sua expansão. 
Tabela 1.1: Número de indivíduos (N), abundância total (Abund.), porcentagem (\%), abundância média (média) e desvio padrão (dp) das larvas de Myctophidae coletadas com a malha fina da rede bongô, entre Cabo de São Tomé e São Sebastião, durante o verão e o inverno de 2002. Abundância expressa em larvas. $\mathrm{m}^{2}$.

\begin{tabular}{|c|c|c|c|c|c|c|c|c|c|c|}
\hline \multirow{2}{*}{ Táxons } & \multicolumn{5}{|c|}{ Verão } & \multicolumn{5}{|c|}{ Inverno } \\
\hline & $\mathrm{N}$ & Abund. & $\%$ & Média. & $d p$ & $\mathrm{~N}$ & Abund. & $\%$ & Média. & $\mathrm{dp}$ \\
\hline \multicolumn{11}{|l|}{ Subfamília Myctophinae } \\
\hline Benthosema suborbitale & 16 & 13,10 & 1,25 & 0,18 & 0,69 & 21 & 13,92 & 2,03 & 0,21 & 0,65 \\
\hline Centrobranchus nigroocellatus & 1 & 0,80 & 0,08 & 0,01 & 0,09 & - & - & - & - & - \\
\hline Hygophum spp. & 1 & 0,81 & 0,08 & 0,01 & 0,10 & 24 & 15,95 & 2,32 & 0,24 & 0,74 \\
\hline Hygophum hygomii & 3 & 2,51 & 0,24 & 0,03 & 0,22 & 21 & 15,96 & 2,33 & 0,24 & 0,88 \\
\hline Hygophum reinhardti & 27 & 21,32 & 2,03 & 0,30 & 0,70 & 10 & 6,44 & 0,94 & 0,10 & 0,28 \\
\hline Myctophum spp. & 5 & 3,96 & 0,38 & 0,06 & 0,23 & 18 & 9,72 & 1,42 & 0,15 & 0,67 \\
\hline Myctophum affine & 391 & 284,16 & 27,06 & 3,95 & 6,78 & 97 & 67,94 & 9,90 & 1,03 & 1,82 \\
\hline Myctophum asperum & 3 & 1,99 & 0,19 & 0,03 & 0,23 & 1 & 0,71 & 0,10 & 0,01 & 0,09 \\
\hline Myctophum nitidulum & 1 & 0,84 & 0,08 & 0,01 & 0,10 & - & - & - & - & - \\
\hline Myctophum obtusirostre & 23 & 18,44 & 1,76 & 0,26 & 0,88 & 4 & 3,74 & 0,54 & 0,06 & 0,37 \\
\hline Myctophm selenops & 2 & 1,65 & 0,16 & 0,02 & 0,14 & - & - & - & - & - \\
\hline Symbolophorus rufinus & - & - & - & - & - & 6 & 3,70 & 0,54 & 0,06 & 0,26 \\
\hline \multicolumn{11}{|l|}{ Subfamília Lampanyctinae } \\
\hline Ceratoscopelus spp. & 9 & 7,55 & 0,72 & 0,10 & 0,89 & 6 & 3,29 & 0,48 & 0,05 & 0,18 \\
\hline Diaphus spp. & 179 & 131,88 & 12,56 & 1,83 & 5,61 & 147 & 103,40 & 15,06 & 1,57 & 4,14 \\
\hline Diaphus tipo slender & 28 & 20,19 & 1,92 & 0,28 & 1,60 & 43 & 31,27 & 4,56 & 0,47 & 1,48 \\
\hline Diaphus tipo stubby & 265 & 185,99 & 17,71 & 2,58 & 7,76 & 160 & 92,74 & 13,51 & 1,41 & 3,02 \\
\hline Lampadena sp. & 1 & 0,66 & 0,06 & 0,01 & 0,08 & - & - & - & - & - \\
\hline Lampanyctus tipo 1 & - & - & - & - & - & 23 & 15,19 & 2,21 & 0,23 & 0,76 \\
\hline Lampanyctus tipo 2 & - & - & - & - & - & 6 & 4,62 & 0,67 & 0,07 & 0,29 \\
\hline Lepidophanes spp. & 110 & 80,74 & 7,69 & 1,12 & 4,10 & 29 & 20,08 & 2,93 & 0,30 & 1,06 \\
\hline Lepidophanes guentheri & 13 & 9,23 & 0,88 & 0,13 & 0,91 & 42 & 31,03 & 4,52 & 0,47 & 1,71 \\
\hline Lobianchia gemellari & 1 & 0,76 & 0,07 & 0,01 & 0,09 & 1 & 0,98 & 0,14 & 0,01 & 0,12 \\
\hline Nannobrachium sp. & 3 & 2,17 & 0,21 & 0,03 & 0,26 & 1 & 0,65 & 0,09 & 0,01 & 0,08 \\
\hline Notolychnus valdiviae & 7 & 5,93 & 0,56 & 0,08 & 0,39 & 2 & 1,25 & 0,18 & 0,02 & 0,15 \\
\hline Notoscopelus caudispinosus & - & - & - & - & - & 24 & 16,95 & 2,47 & 0,26 & 0,55 \\
\hline $\mathrm{NI}$ & 355 & 255,46 & 24,33 & 3,55 & 5,98 & 329 & 226,93 & 33,06 & 3,44 & 6,30 \\
\hline TOTAL & 1.444 & 1050,14 & 100,00 & 14,59 & 20,04 & 1.015 & 686,46 & 100,00 & 10,40 & 13,20 \\
\hline
\end{tabular}


Tabela 1.2: Número de indivíduos (N), frequência de ocorrência (Fo \%.), densidade média (média) e desvio padrão (dp) das larvas de Myctophidae coletadas em estratos de $20 \mathrm{~m}$ de profundidade com a rede Multinet, entre cabo de São Tomé e São Sebastião, durante o verão de 2002. Densidade expressa em larvas. $100 \mathrm{~m}^{-3}$.

\begin{tabular}{|c|c|c|c|c|c|c|c|c|c|c|c|c|c|c|c|c|c|c|c|c|}
\hline \multirow{2}{*}{ Táxons } & \multicolumn{4}{|c|}{$0-20 \mathrm{~m}$} & \multicolumn{4}{|c|}{$20-40 \mathrm{~m}$} & \multicolumn{4}{|c|}{$40-60 \mathrm{~m}$} & \multicolumn{4}{|c|}{$60-80 \mathrm{~m}$} & \multicolumn{4}{|c|}{$80-100 \mathrm{~m}$} \\
\hline & $\mathrm{N}$ & Fo & Média & $\mathrm{dp}$ & $\mathrm{N}$ & Fo & Média & $\mathrm{dp}$ & $\mathrm{N}$ & Fo & Média & $\mathrm{dp}$ & $\mathrm{N}$ & Fo & Média & $\mathrm{dp}$ & $\mathrm{N}$ & Fo & Média & $\mathrm{dp}$ \\
\hline \multicolumn{21}{|l|}{ Sufamília Myctophinae } \\
\hline Benthosema suborbitale & - & - & - & - & 1 & 3.4 & 0.21 & 1.12 & 2 & 7.4 & 0.41 & 1.51 & 4 & 4.3 & 1.26 & 6.04 & 1 & 4.8 & 0.15 & 0.68 \\
\hline Diogenichthys atlanticus & - & - & - & - & - & - & - & - & - & - & - & - & - & - & - & - & 1 & 4.8 & 0.30 & 1.35 \\
\hline Hygophum spp. & - & - & - & - & - & - & - & - & 2 & 3.7 & 0.32 & 1.68 & 2 & 4.3 & 0.36 & 1.73 & - & - & - & 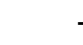 \\
\hline Hygophum hygomii & - & - & - & - & - & - & - & - & - & - & - & - & - & - & - & - & - & - & - & - \\
\hline Hygophum reinhardti & 2 & 6.9 & 0.20 & 0.79 & - & - & - & - & 1 & 3.7 & 0.23 & 1.19 & 5 & 13.0 & 1.29 & 3.60 & 2 & 4.8 & 0.59 & 2.71 \\
\hline Myctophum spp. & 1 & 3.4 & 0.08 & 0.45 & - & - & - & - & 1 & 3.7 & 0.25 & 1.29 & 1 & 4.3 & 0.24 & 1.17 & 1 & 4.8 & 0.20 & 0.94 \\
\hline Myctophum affine & 24 & 27.6 & 3.27 & 8.83 & 46 & 41.4 & 9.03 & 20.57 & 46 & 37.0 & 9.10 & 16.34 & 37 & 52.2 & 9.62 & 14.19 & 59 & 38.1 & 8.24 & 16.27 \\
\hline Myctophum asperum & - & - & - & - & - & - & - & - & - & - & - & - & 1 & 4.3 & 0.28 & 1.35 & - & - & - & - \\
\hline Myctophum nitidulum & - & - & - & - & - & - & - & - & - & - & - & - & - & - & - & - & - & - & - & - \\
\hline Myctophum obtusirostre & - & - & - & - & 3 & 6.9 & 0.60 & 2.54 & 6 & 14.8 & 1.15 & 3.07 & 3 & 8.7 & 0.73 & 2.56 & - & - & - & - \\
\hline Symbolophorus rufinus & - & - & - & - & - & - & - & - & - & - & - & - & 1 & 4.3 & 0.28 & 1.35 & 1 & 4.8 & 0.30 & 1.35 \\
\hline \multicolumn{21}{|l|}{ Subfamília Lampanyctinae } \\
\hline Ceratoscopelus spp. & 1 & 3.4 & 0.13 & 0.70 & - & - & - & - & - & - & - & - & - & - & - & - & - & - & - & - \\
\hline Diaphus spp. & 29 & 24.1 & 3.38 & 10.34 & 26 & 24.1 & 4.09 & 9.14 & 14 & 29.6 & 4.46 & 10.37 & 3 & 8.7 & 0.61 & 2.07 & 2 & 9.5 & 0.41 & 1.29 \\
\hline Diaphus tipo slender & 1 & 3.4 & 0.08 & 0.41 & 1 & 3.4 & 0.34 & 1.84 & 1 & 3.7 & 0.19 & 0.98 & - & - & - & - & - & - & - & 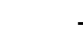 \\
\hline Diaphus tipo stubby & 58 & 24.1 & 13.75 & 65.25 & 39 & 17.2 & 10.67 & 35.55 & 9 & 11.1 & 1.86 & 8.18 & 4 & 8.7 & 0.76 & 2.78 & 2 & 4.8 & 0.14 & 0.63 \\
\hline Lampanyctus tipo 1 & 0 & 0.0 & 0.00 & 0.00 & - & - & - & - & - & - & - & - & - & - & - & - & - & - & - & 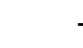 \\
\hline Lampanyctus tipo 2 & 0 & 0.0 & 0.00 & 0.00 & - & - & - & - & - & - & - & - & - & - & - & - & - & - & - & - \\
\hline Lepidophanes spp. & 49 & 31.0 & 4.62 & 9.88 & 13 & 13.8 & 3.00 & 8.51 & - & - & - & - & 1 & 4.3 & 0.24 & 1.16 & 51 & 4.8 & 9.66 & 44.27 \\
\hline Lepidophanes guentheri & 1 & 3.4 & 0.06 & 0.33 & 8 & 3.4 & 1.66 & 8.96 & - & - & - & - & - & - & - & - & - & - & - & - \\
\hline Lobianchia gemellari & - & - & - & - & - & - & - & - & 1 & 3.7 & 0.23 & 1.19 & - & - & - & - & 2 & 9.5 & 0.35 & 1.13 \\
\hline Nannobrachium sp. & - & - & - & - & - & - & - & - & - & - & - & - & 1 & 4.3 & 0.15 & 0.71 & - & - & - & - \\
\hline Nololychnus valdiviae & - & - & - & - & - & - & - & - & - & - & - & - & 2 & 8.7 & 0.60 & 1.98 & 1 & 4.8 & 0.30 & 1.35 \\
\hline Notoscopelus caudispinosus & - & - & - & - & - & - & - & - & - & - & - & - & - & - & - & - & - & - & - & - \\
\hline $\mathrm{NI}$ & 75 & 37.9 & 8.72 & 20.23 & 52 & 41.4 & 8.58 & 15.55 & 18 & 29.6 & 3.05 & 5.22 & 17 & 43.5 & 4.47 & 7.21 & 3 & 9.5 & 0.76 & 2.78 \\
\hline $\mathrm{N}$ total & 241 & & & & 189 & & & & 101 & & & & 82 & & & & 126 & & & \\
\hline Número de amostras & 29 & & & & 29 & & & & 27 & & & & 23 & & & & 21 & & & \\
\hline
\end{tabular}


Tabela 1.3: Número de indivíduos (N), frequência de ocorrência (Fo \%.), densidade média (média) e desvio padrão (dp) das larvas de Myctophidae coletadas em estratos de $20 \mathrm{~m}$ de profundidade com a rede Multinet, entre cabo de São Tomé e São Sebastião, durante o inverno de 2002. Densidade expressa em larvas. $100 \mathrm{~m}^{-3}$.

\begin{tabular}{|c|c|c|c|c|c|c|c|c|c|c|c|c|c|c|c|c|c|c|c|c|}
\hline \multirow{2}{*}{ Táxons } & \multicolumn{4}{|c|}{$0-20 \mathrm{~m}$} & \multicolumn{4}{|c|}{$20-40 \mathrm{~m}$} & \multicolumn{4}{|c|}{$40-60 \mathrm{~m}$} & \multicolumn{4}{|c|}{$60-80 \mathrm{~m}$} & \multicolumn{4}{|c|}{$80-100 \mathrm{~m}$} \\
\hline & $\mathrm{N}$ & Fo & Média & $\mathrm{dp}$ & $\mathrm{N}$ & Fo & Média & $\mathrm{dp}$ & $\mathrm{N}$ & Fo & Média & $\mathrm{dp}$ & $\mathrm{N}$ & Fo & Média & $\mathrm{dp}$ & $\mathrm{N}$ & Fo & Média & $\mathrm{dp}$ \\
\hline \multicolumn{21}{|l|}{ Sufamília Myctophinae } \\
\hline Benthosema suborbitale & - & - & - & - & 0 & 0.0 & 0.00 & 0.00 & 1 & 5.3 & 0.24 & 1.06 & 2 & 11.1 & 0.53 & 1.60 & 1 & 6.7 & 0.18 & 0.69 \\
\hline Diogenichthys atlanticus & - & - & - & - & 0 & 0 & 0.00 & 0.00 & 0 & 0 & 0 & 0 & 0 & 0 & 0 & 0 & 0 & 0.0 & 0.00 & 0.00 \\
\hline Hygophum spp. & 3 & 9 & 0 & 1 & 3 & 14 & 0.41 & 1.06 & 2 & 10.5 & 0.47 & 1.40 & 3 & 5.6 & 0.52 & 2.22 & 0 & 0 & 0 & 0 \\
\hline Hygophum hygomii & 3 & 9 & 0 & 1 & 4 & 14 & 1.66 & 5.77 & 3 & 16 & 1 & 2 & 1 & 6 & 0 & 1 & 2 & 7 & 0 & 1 \\
\hline Hygophum reinhardti & 4 & 9.1 & 0.11 & 0.39 & 1 & 5 & 0.21 & 0.98 & 1 & 5.3 & 0.22 & 0.95 & 1 & 5.6 & 0.26 & 1.12 & 0 & 0.0 & 0.00 & 0.00 \\
\hline Myctophum spp. & - & - & - & - & 0 & - & - & - & - & - & - & - & - & - & - & - & - & - & - & - \\
\hline Myctophum affine & 20 & 4.5 & 0.79 & 3.72 & 23 & 36.4 & 3.98 & 7.96 & 20 & 42.1 & 4.70 & 8.54 & 4 & 16.7 & 0.75 & 1.93 & 3 & 13.3 & 0.39 & 1.02 \\
\hline Myctophum asperum & - & - & - & - & 0 & - & - & - & - & - & - & - & - & - & - & - & - & - & - & - \\
\hline Myctophum nitidulum & - & - & - & - & 1 & 5 & 0.13 & 0.61 & 0 & 0 & 0 & 0 & 0 & 0 & 0 & 0 & 0 & 0 & 0 & 0 \\
\hline Myctophum obtusirostre & - & - & - & - & 2 & 9.1 & 0.34 & 1.14 & 1 & 5.3 & 0.23 & 1.00 & 1 & 5.6 & 0.20 & 0.87 & 0 & 0 & 0 & 0 \\
\hline Symbolophorus rufinus & - & - & - & - & 1 & 5 & 0.27 & 1.28 & 1 & 5 & 0 & 1 & 2 & 11.1 & 0.60 & 1.84 & 0 & 0.0 & 0.00 & 0.00 \\
\hline \multicolumn{21}{|l|}{ Subfamília Lampanyctinae } \\
\hline Ceratoscopelus spp. & 0 & 0.0 & 0.00 & 0.00 & 0 & 0 & 0.00 & 0.00 & 0 & 0 & 0 & 0 & 0 & 0 & 0 & 0 & 0 & 0 & 0 & 0 \\
\hline Diaphus spp. & 1 & 4.5 & 0.07 & 0.34 & 10 & 18.2 & 1.37 & 3.46 & 0 & 0.0 & 0.00 & 0.00 & 0 & 0.0 & 0.00 & 0.00 & 0 & 0.0 & 0.00 & 0.00 \\
\hline Diaphus tipo slender & 4 & 18.2 & 0.36 & 0.86 & 2 & 9.1 & 0.25 & 0.82 & 0 & 0.0 & 0.00 & 0.00 & 1 & 6 & 0 & 1 & 0 & 0 & 0 & 0 \\
\hline Diaphus tipo stubby & 26 & 31.8 & 3.28 & 9.75 & 29 & 22.7 & 4.90 & 11.66 & 43 & 36.8 & 8.41 & 17.47 & 11 & 44.4 & 2.03 & 2.72 & 1 & 6.7 & 0.18 & 0.69 \\
\hline Lampanyctus tipo 1 & 4 & 18.2 & 0.28 & 0.78 & 1 & 5 & 0.12 & 0.57 & 1 & 5 & 0 & 2 & 0 & 0 & 0 & 0 & 0 & 0 & 0 & 0 \\
\hline Lampanyctus tipo 2 & 1 & 4.5 & 0.07 & 0.34 & 0 & 0 & 0.00 & 0.00 & 0 & 0 & 0 & 0 & 0 & 0 & 0 & 0 & 1 & 7 & 0 & 1 \\
\hline Lepidophanes spp. & 0 & 0.0 & 0.00 & 0.00 & 0 & 0.0 & 0.00 & 0.00 & 0 & 0 & 0 & 0 & 0 & 0.0 & 0.00 & 0.00 & 0 & 0.0 & 0.00 & 0.00 \\
\hline Lepidophanes guentheri & 17 & 27.3 & 1.21 & 2.75 & 3 & 9.1 & 0.63 & 2.17 & 1 & 5 & 0 & 2 & 0 & 0 & 0 & 0 & 0 & 0 & 0 & 0 \\
\hline Lobianchia gemellari & 0 & 0 & 0 & 0 & 0 & 0 & 0.00 & 0.00 & 0 & 0.0 & 0.00 & 0.00 & 0 & 0 & 0 & 0 & 0 & 0.0 & 0.00 & 0.00 \\
\hline Nannobrachium sp. & 0 & 0 & 0 & 0 & 0 & 0 & 0.00 & 0.00 & 0 & 0 & 0 & 0 & 0 & 0.0 & 0.00 & 0.00 & 0 & 0 & 0 & 0 \\
\hline Nololychnus valdiviae & 0 & 0 & 0 & 0 & 0 & 0 & 0.00 & 0.00 & 0 & 0 & 0 & 0 & 0 & 0.0 & 0.00 & 0.00 & 0 & 0.0 & 0.00 & 0.00 \\
\hline Notoscopelus caudispinosus & 2 & 9 & 1 & 2 & 1 & 5 & 0.13 & 0.61 & 0 & 0 & 0 & 0 & 0 & 0 & 0 & 0 & 0 & 0 & 0 & 0 \\
\hline $\mathrm{NI}$ & 33 & 31.8 & 2.74 & 5.27 & 12 & 31.8 & 1.96 & 3.60 & 8 & 26.3 & 1.92 & 3.83 & 11 & 22.2 & 2.59 & 6.64 & 4 & 20.0 & 0.96 & 2.52 \\
\hline $\mathrm{N}$ total & 118 & & & & 93 & & & & 82 & & & & 37 & & & & 12 & & & \\
\hline Número de amostras & 22 & & & & 21 & & & & 19 & & & & 18 & & & & 15 & & & \\
\hline
\end{tabular}


Tabela 1.4: Resultado do teste de permutação de Monte Carlo em relação às variáveis ambientais e espaciais entre cabo de São Tomé e São Sebastião, durante o verão de 2002.

\begin{tabular}{lrr}
\hline Variável & $\mathrm{p}$ & $\mathrm{F}$ \\
\hline Salinidade & 0,0001 & 4,95 \\
Prof. coleta & 0,0009 & 397 \\
Radial & 0,0031 & 3,75 \\
Temperatura & 0,0018 & 4,00 \\
Biovolume & 0,5069 & 0,74 \\
Dist. costa & 0,6836 & 0,69 \\
\hline
\end{tabular}

Tabela 1.5: Resultado da análise de partição das variáveis ambientais e espaciais para a explicação da distribuição das espécies de Myctophidae entre cabo de São Tomé e São Sebastião durante o verão de 2002.

\begin{tabular}{lrrrr}
\hline & \multicolumn{4}{c}{ ACC } \\
\cline { 2 - 5 } & Ambiental & Espacial & Amb- Espacial & Espacial - Amb \\
\hline Soma de todos autovalores naturais & 2,495 & 2,495 & 2,040 & 2,173 \\
Soma de todos autovalores canônicos & 0,298 & 0,455 & 0,120 & 0,276 \\
Explicação & $11,9 \%$ & $18,2 \%$ & $5,9 \%$ & $12,7 \%$ \\
\hline & & & & \\
Variação Ambiental - Espacial & $5,9 \%$ & & & \\
Variação Ambiental + Espacial & $6,1 \%$ & & & \\
Variação Espacial - Ambiental & $12,7 \%$ & & & \\
Variação não explicada & $75,4 \%$ & & & \\
\hline
\end{tabular}


Tabela 1.6: Resultado da análise de correspondência canônica e correlação da variáveis significativas com os quatro primeiros eixos, para a explicação da distribuição das espécies de Myctophidae entre cabo de São Tomé e São Sebastião durante o verão de 2002.

\begin{tabular}{lrrrrr}
\hline & \multicolumn{2}{c}{ Eixos } & \multicolumn{2}{c}{ Inércia total } \\
\hline Autovalores & 1 & 2 & 3 & 4 & \\
Correlação espécie-ambiente & 0,289 & 0,232 & 0,042 & 0,012 & 2,495 \\
Porcentagem de variância acumulada: & 0,643 & 0,643 & 0,358 & 0,329 & \\
nos dados de espécies & & & & & \\
na relação espécie ambiente & 11,6 & 20,9 & 22,6 & 23 & \\
Soma de todos autovalores naturais & 50,3 & 90,6 & 98 & 100 & \\
Soma de todos autovalores canônicos & & & & & 2,495 \\
& & & & & 0,575 \\
\hline Temperatura & & & & & \\
$\quad$ Salinidade & $-0,563$ & $-0,3993$ & 0,6514 & $-0,3151$ & \\
Radial & $-0,7645$ & 0,1906 & $-0,0392$ & $-0,6145$ & \\
Profundidade de Coleta & $-0,0601$ & 0,5537 & 0,7352 & $-0,3864$ & \\
& $-0,339$ & 0,7298 & $-0,4615$ & 0,3735 & \\
\hline
\end{tabular}


Tabela 1.7: Resultado do teste de permutação de Monte Carlo em relação às variáveis ambientais e espaciais entre cabo de São Tomé e São Sebastião, durante o inverno de 2002.

\begin{tabular}{lrr}
\hline Variável & $\mathrm{p}$ & $\mathrm{F}$ \\
\hline Dist. costa & 0,0002 & 2,88 \\
Prof. coleta & 0,0145 & 2,1 \\
Radial & 0,2376 & 1,26 \\
Temperatura & 0,2638 & 1,24 \\
Salinidade & 0,307 & 1,17 \\
Biovolume & 0,6674 & 0,75 \\
\hline
\end{tabular}

Tabela 1.8: Resultado da análise de partição das variáveis ambientais e espaciais para a explicação da distribuição das espécies de Myctophidae entre cabo de São Tomé e São Sebastião durante o inverno de 2002.

\begin{tabular}{lrrrr}
\hline & \multicolumn{3}{c}{ ACC } \\
\cline { 2 - 5 } & Ambiental & Espacial & Amb- Espacial & Espacial - Amb \\
\hline Soma de todos autovalores naturais & 5,157 & 5,157 & 4.589 & 4.791 \\
Soma de todos autovalores & 0,194 & 0,455 & 0 & 0.399 \\
canônicos & 3,8 & 8,8 & 0.0 & 8.3 \\
Explicação (\%) & & & & \\
\hline & 0,0 & & & \\
Variação Ambiental - Espacial & 3,8 & & & \\
Variação Ambiental + Espacial & 8,3 & & & \\
Variação Espacial -Ambiental & 87,9 & & & \\
Variação não explicada & & & & \\
\end{tabular}


Tabela 1.9: Resultado da análise de correspondência canônica e correlação da variáveis significativas com os quatro primeiros eixos, para a explicação da distribuição das espécies de Myctophidae entre cabo de São Tomé e São Sebastião durante o inverno de 2002.

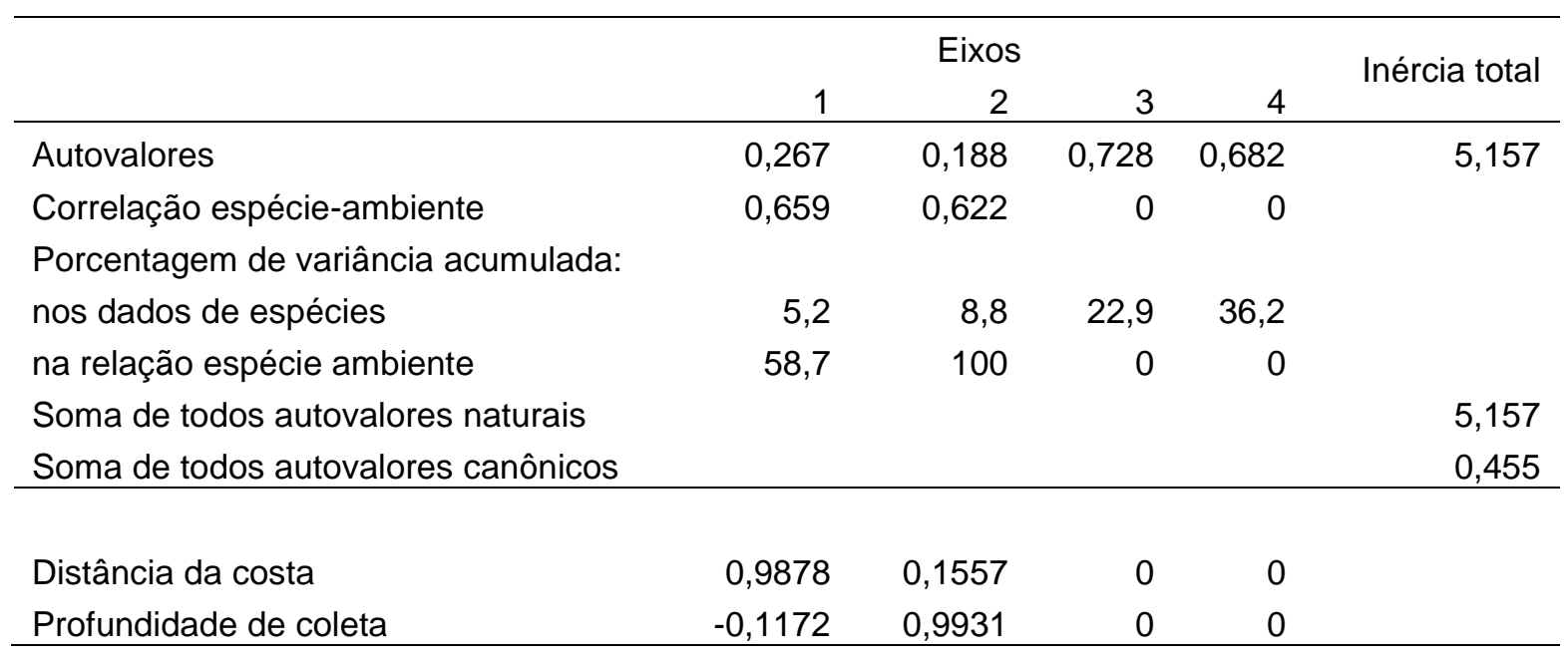



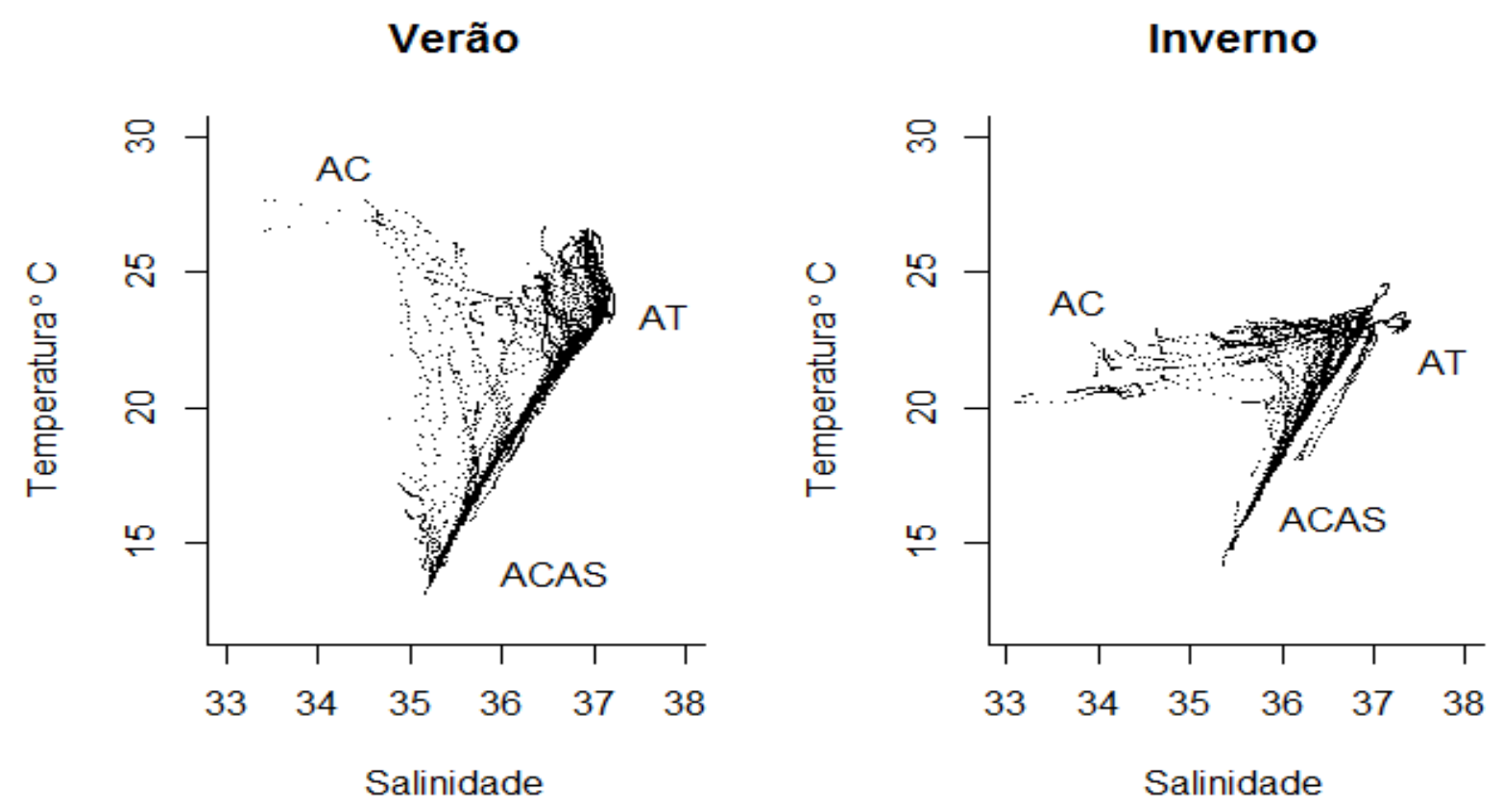

Figura 1.1: Diagramas T-S mostrando a presença das massas de água, Água Costeira (AC), Água Tropical (AT) e Água Central do Atlântico Sul (ACAS), entre cabo de São Tomé (RJ) e ilha de São Sebastião (SP) durante o verão e o inverno de 2002. 

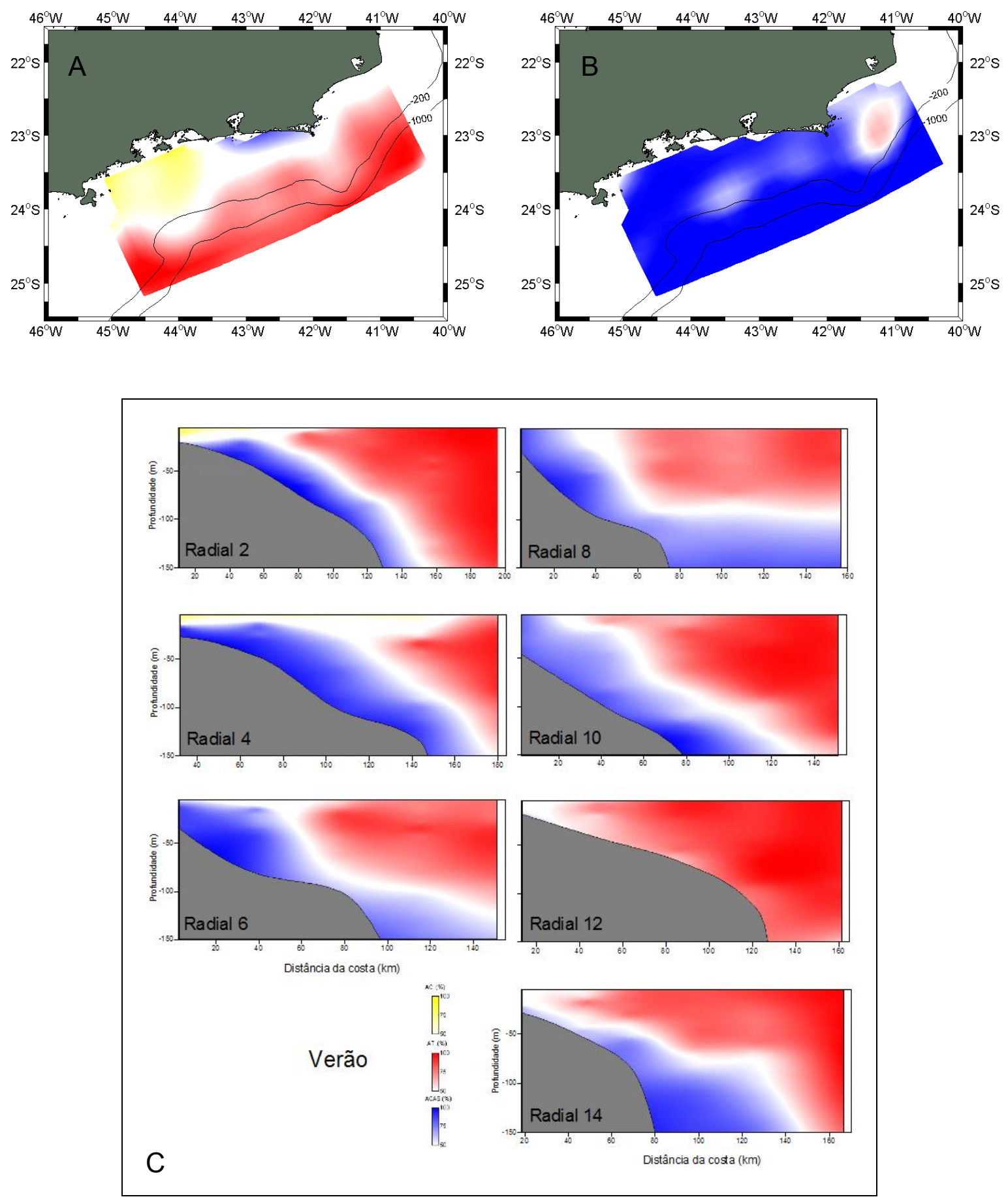

Figura 1.2: Distribuição percentual das massas de água Água Costeira (AC), Água Tropical (AT) e Água Central do Atlântico Sul (ACAS) entre cabo de São Tomé e ilha de São Sebastião durante o verão de 2002. (A): distribuição horizontal a $5 \mathrm{~m}$ de profundidade; (B): distribuição horizontal junto ao fundo; (C): distribuição vertical. (Figuras B e $C$ cedidas por Rafael A. de Mattos) 

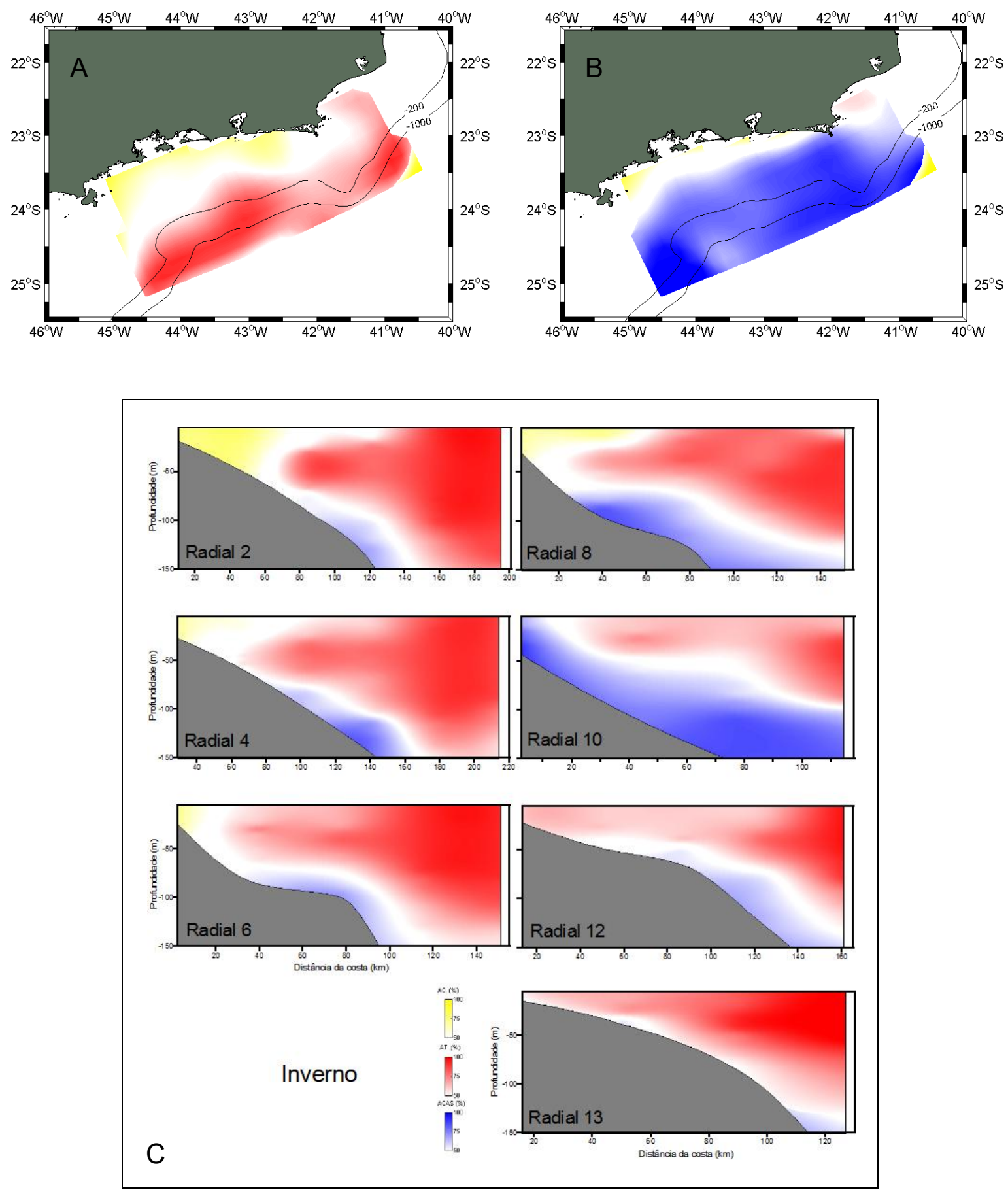

Figura 1.3: Distribuição percentual das massas de água Água Costeira (AC), Água Tropical (AT) e Água Central do Atlântico Sul (ACAS) entre cabo de São Tomé e ilha de São Sebastião durante o inverno de 2002. (A): distribuição horizontal a $5 \mathrm{~m}$ de profundidade; (B): distribuição horizontal junto ao fundo; (C): distribuição vertical. (Figuras B e C cedidas por Rafael A. de Mattos) 

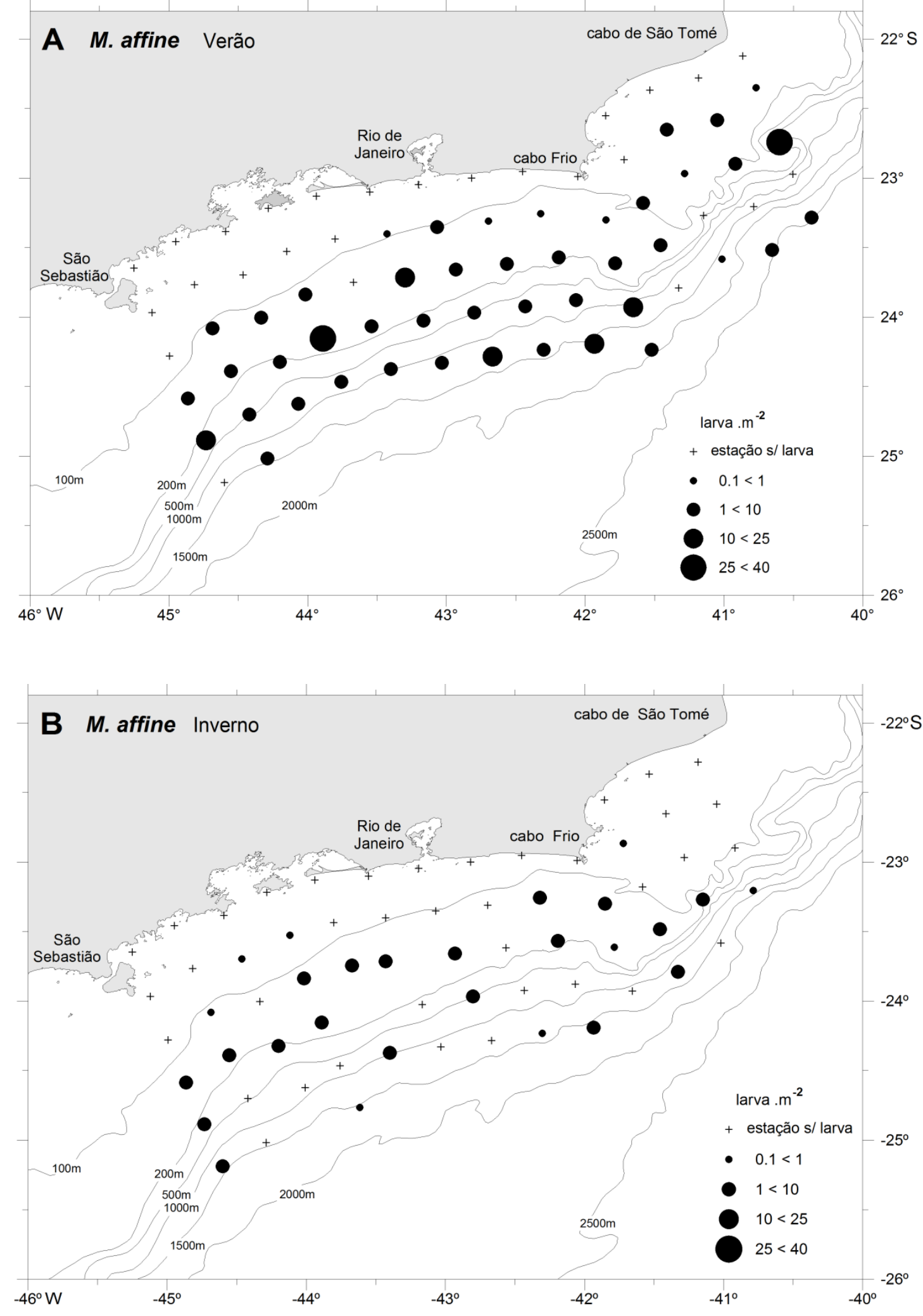

Figura 1.4: Distribuição horizontal e abundância das larvas de Myctophum affine entre cabo de São Tomé e ilha de São Sebastião durante o verão (A) e o inverno (B) de 2002. 

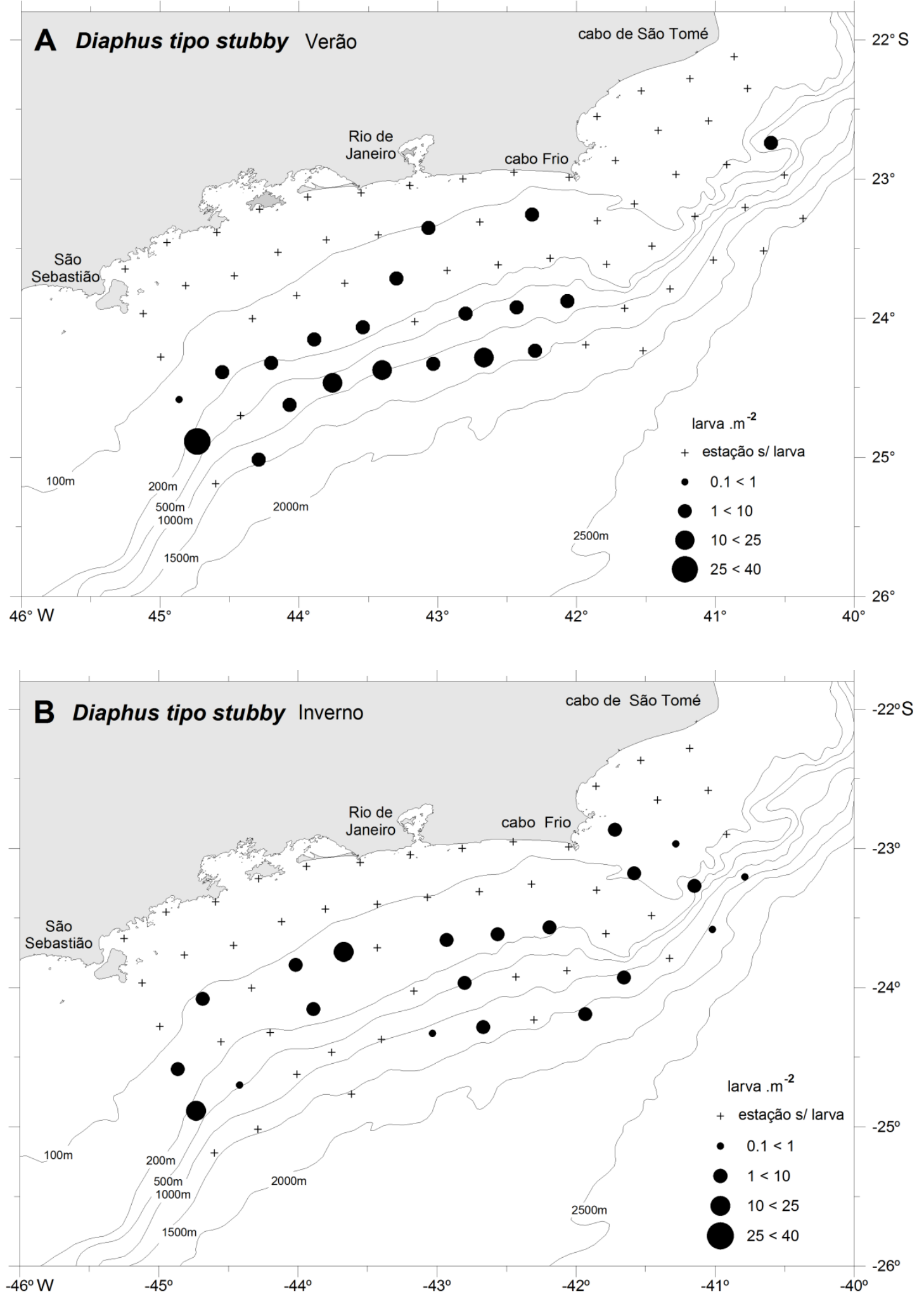

Figura 1.5: Distribuição horizontal e abundância das larvas de Diaphus tipo stubby entre cabo de São Tomé e ilha de São Sebastião durante o verão (A) e o inverno (B) de 2002. 

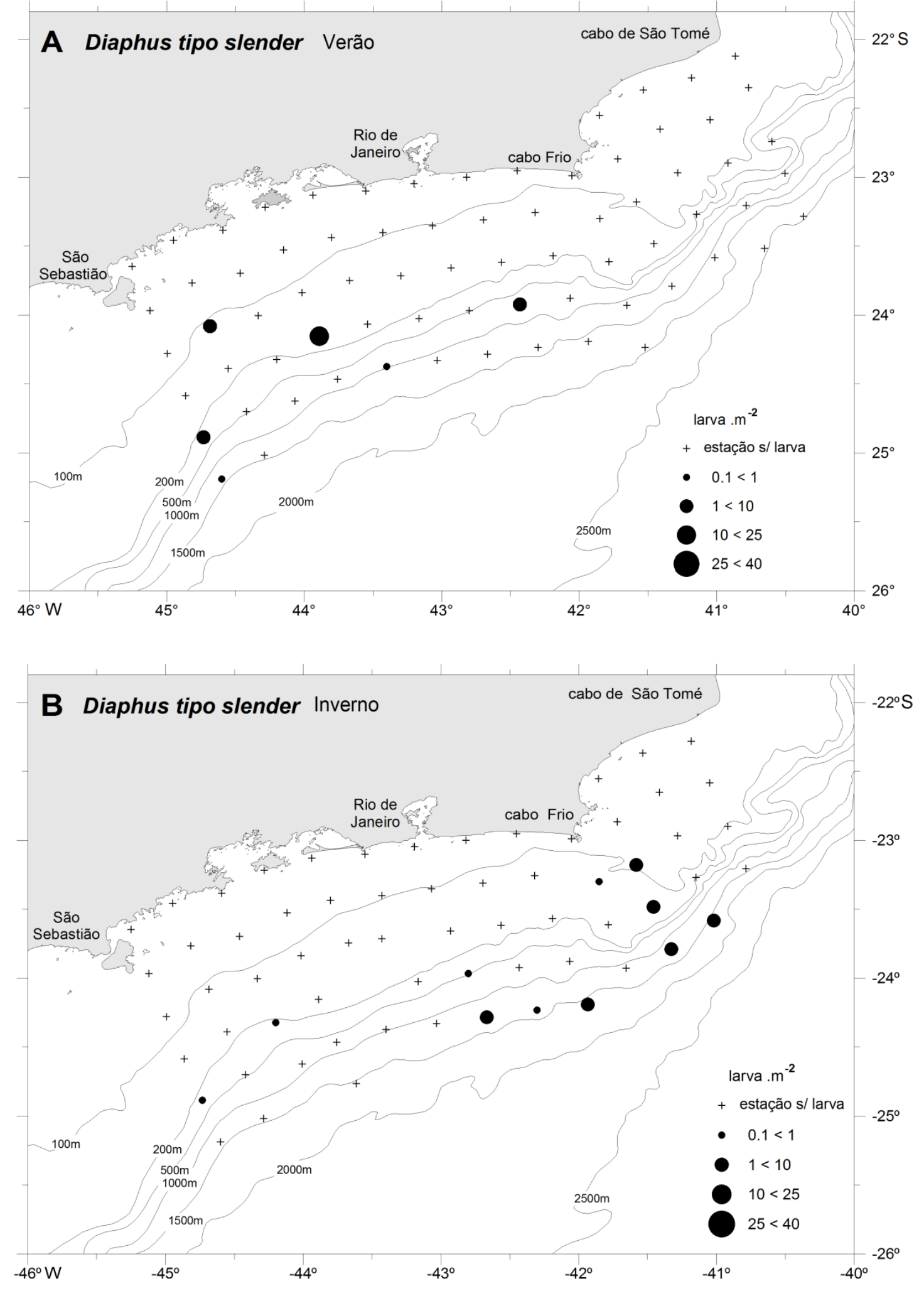

Figura 1.6: Distribuição horizontal e abundância das larvas de Diaphus tipo slender entre cabo de São Tomé e ilha de São Sebastião durante o verão (A) e o inverno (B) de 2002. 

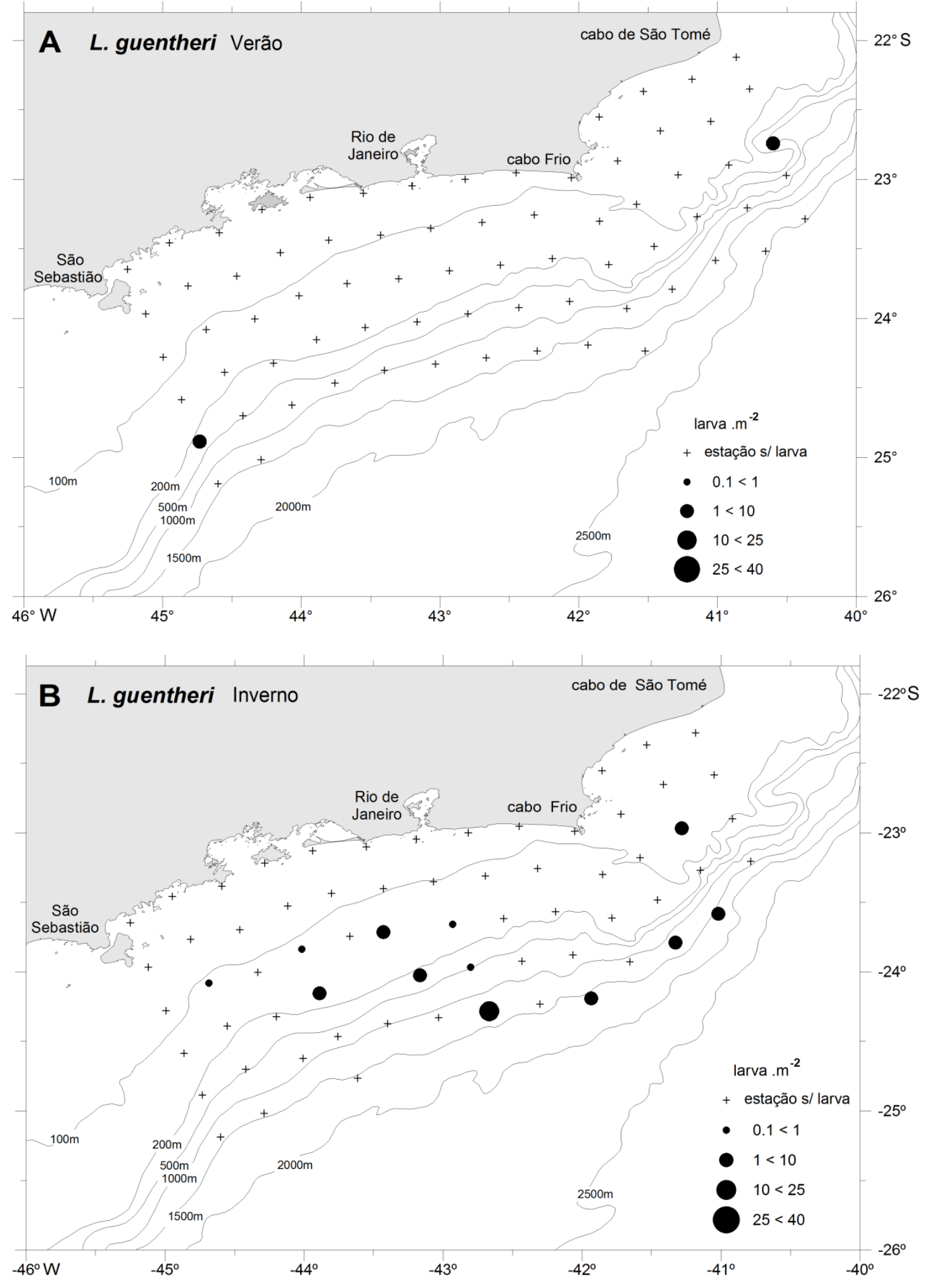

Figura 1.7: Distribuição horizontal e abundância das larvas de Lepidophanes guentheri entre cabo de São Tomé e ilha de São Sebastião durante o verão $(A)$ e o inverno (B) de 2002. 

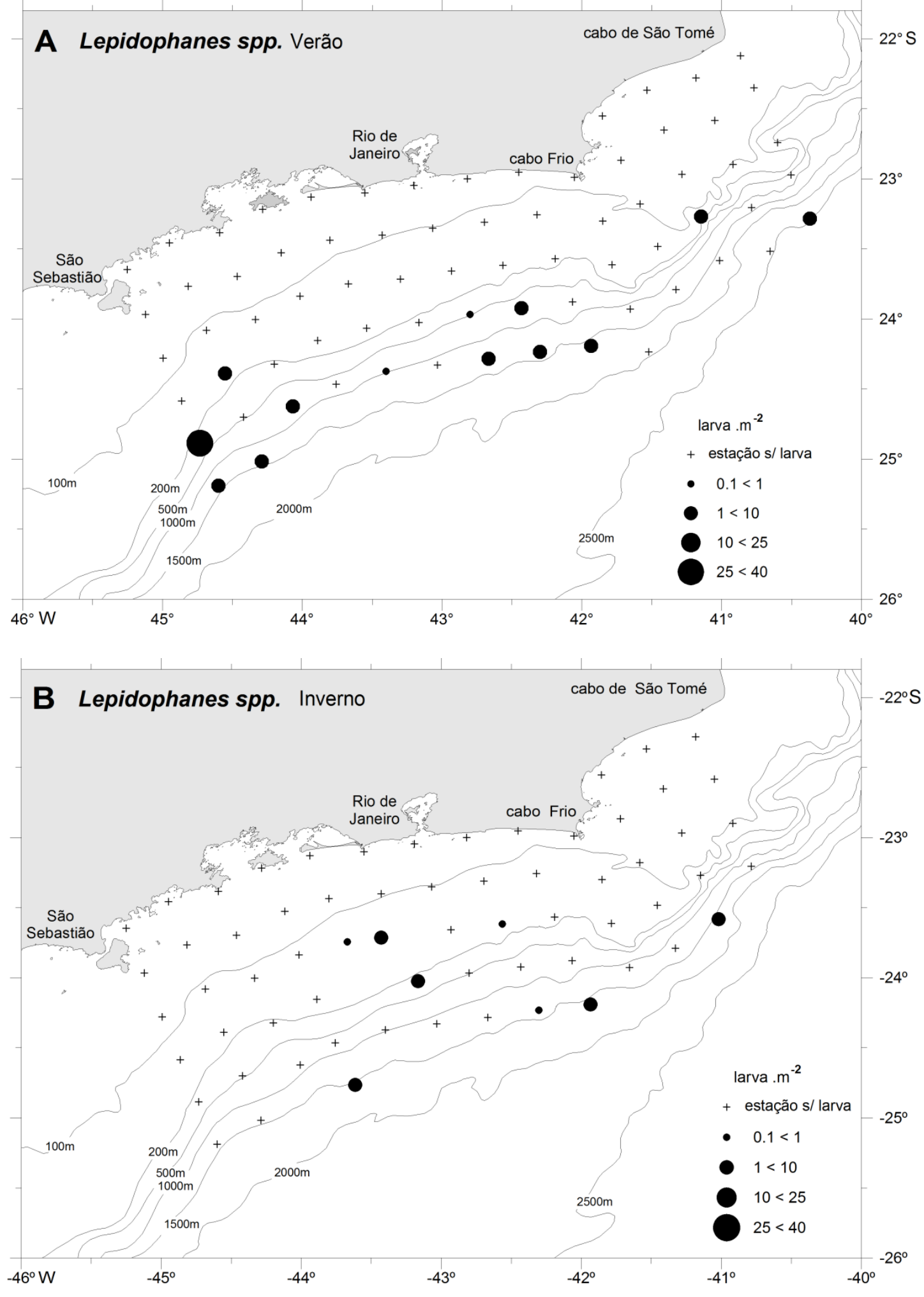

Figura 1.8: Distribuição horizontal e abundância das larvas de Lepidophanes spp. entre cabo de São Tomé e ilha de São Sebastião durante o verão (A) e o inverno (B) de 2002. 

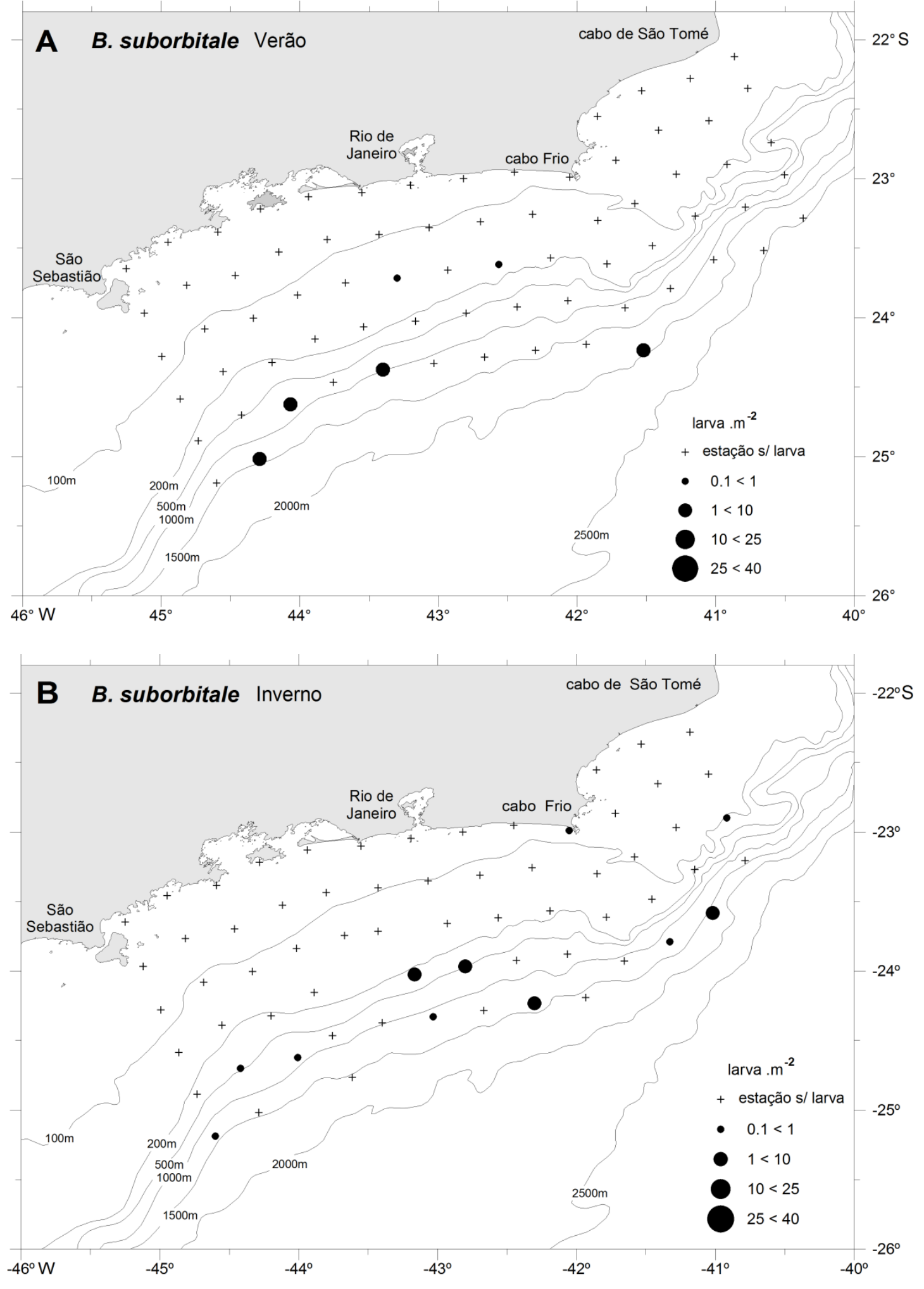

Figura 1.9: Distribuição horizontal e abundância das larvas de Benthosema suborbitale entre cabo de São Tomé e ilha de São Sebastião durante o verão $(A)$ e o inverno (B) de 2002. 

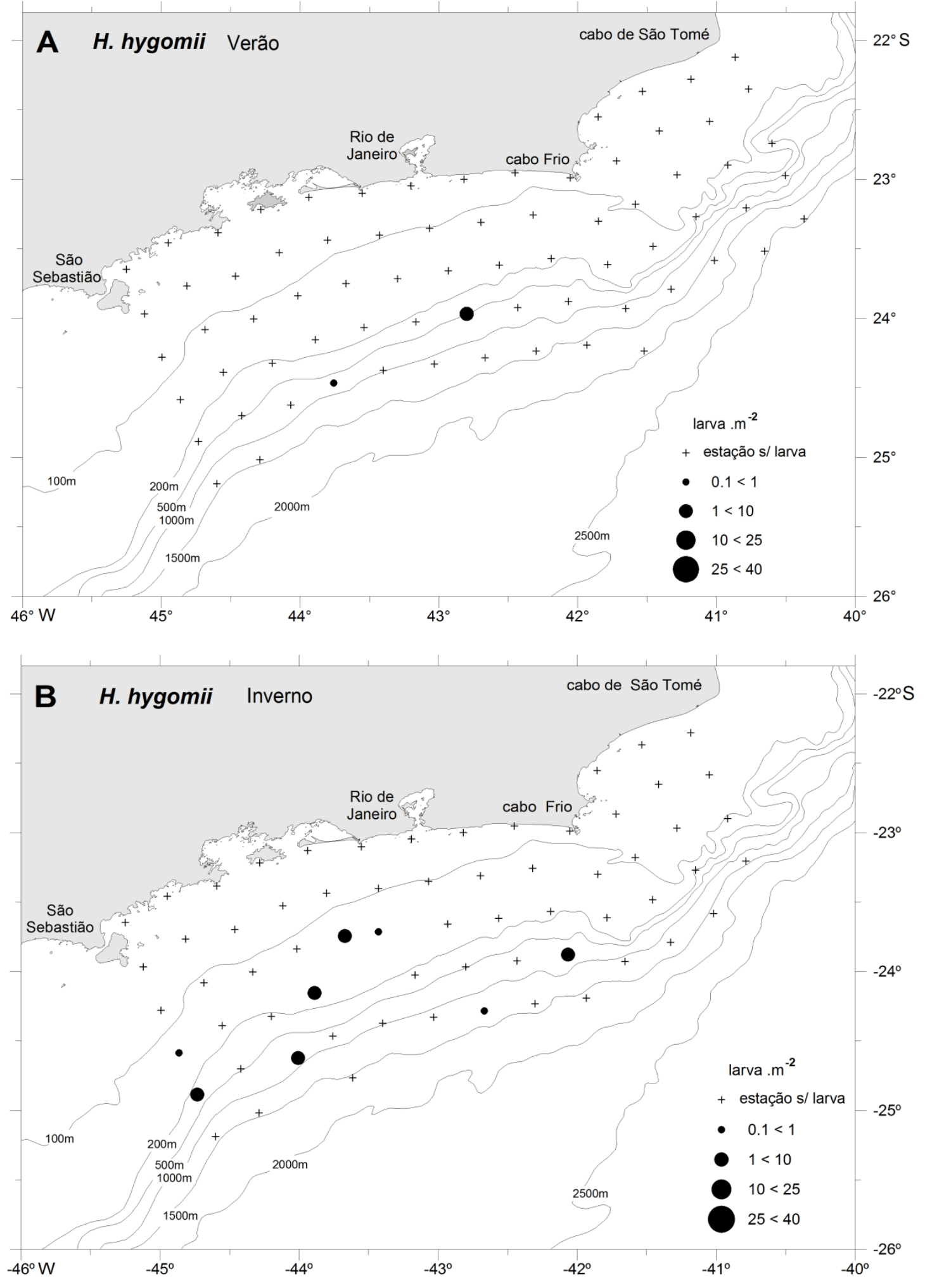

Figura 1.10: Distribuição horizontal e abundância das larvas de Hygophum hygomii entre cabo de São Tomé e ilha de São Sebastião durante o verão (A) e o inverno (B) de 2002. 

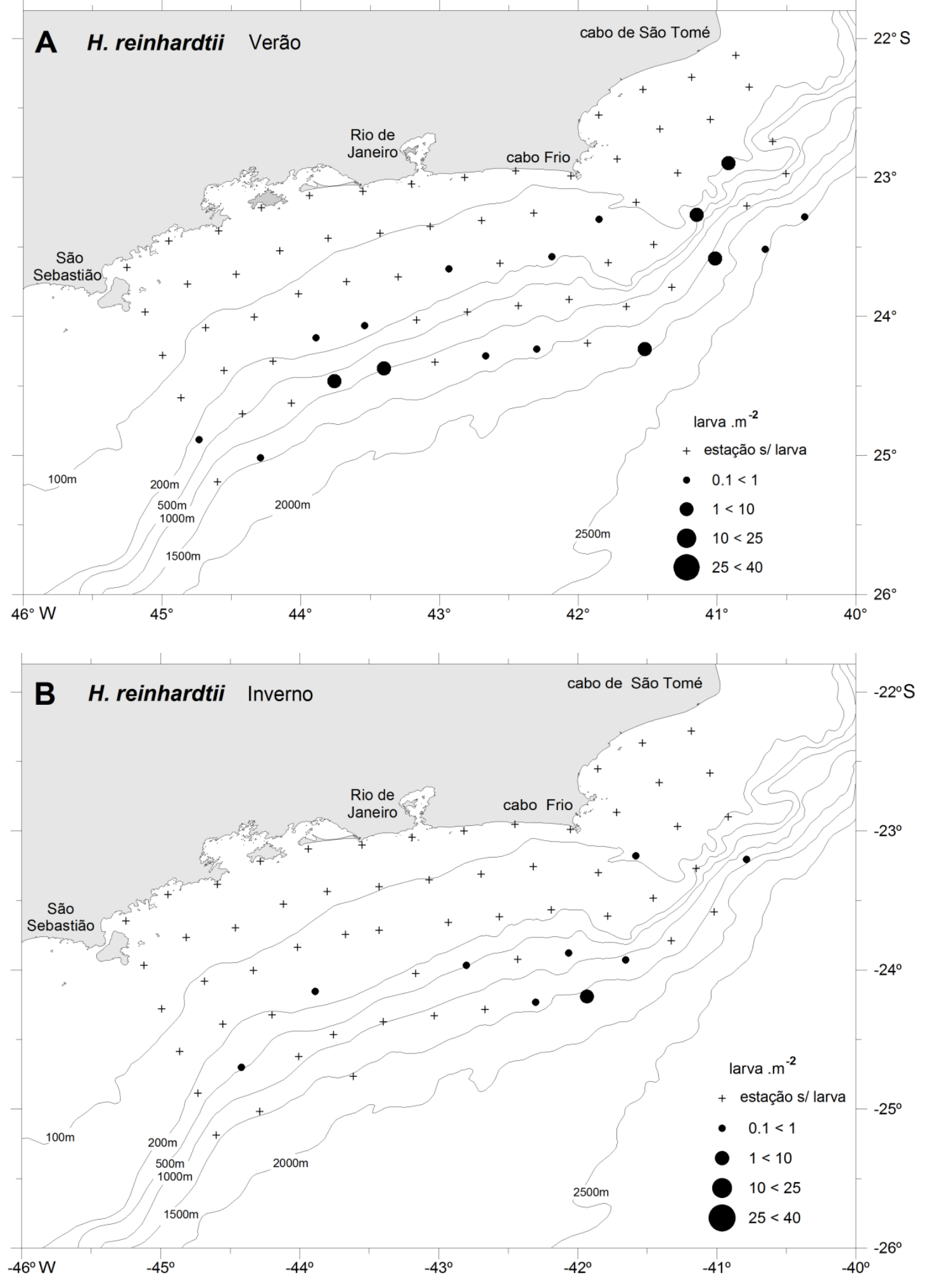

Figura 1.11: Distribuição horizontal e abundância das larvas de Hygophum reinhardtii entre cabo de São Tomé e ilha de São Sebastião durante o verão (A) e o inverno (B) de 2002. 

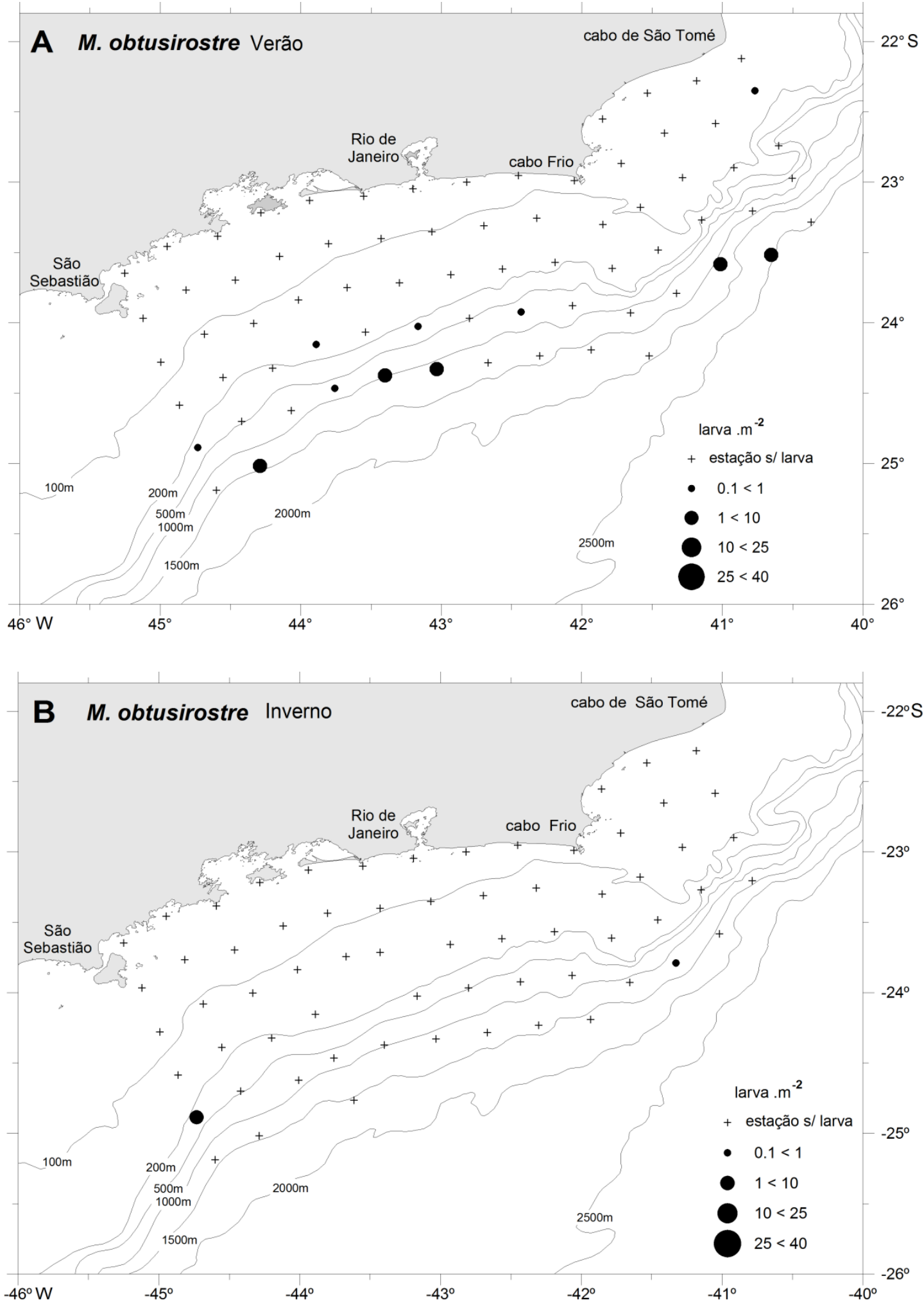

Figura 1.12: Distribuição horizontal e abundância das larvas de Myctophum obtusirostre entre cabo de São Tomé e ilha de São Sebastião durante o verão $(A)$ e o inverno (B) de 2002. 

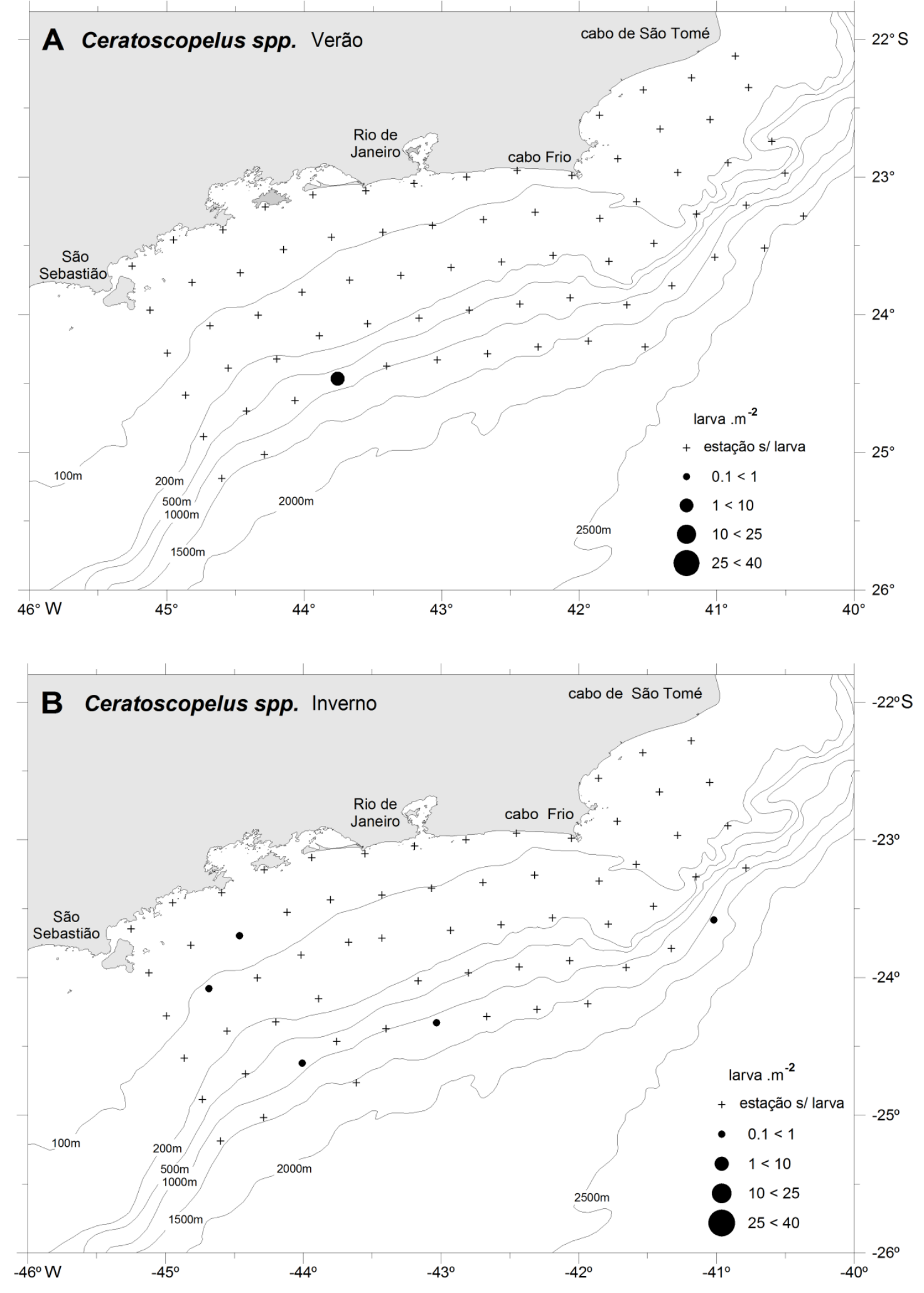

Figura 1.13: Distribuição horizontal e abundância das larvas de Ceratoscopelus spp. entre cabo de São Tomé e ilha de São Sebastião durante o verão (A) e o inverno (B) de 2002. 

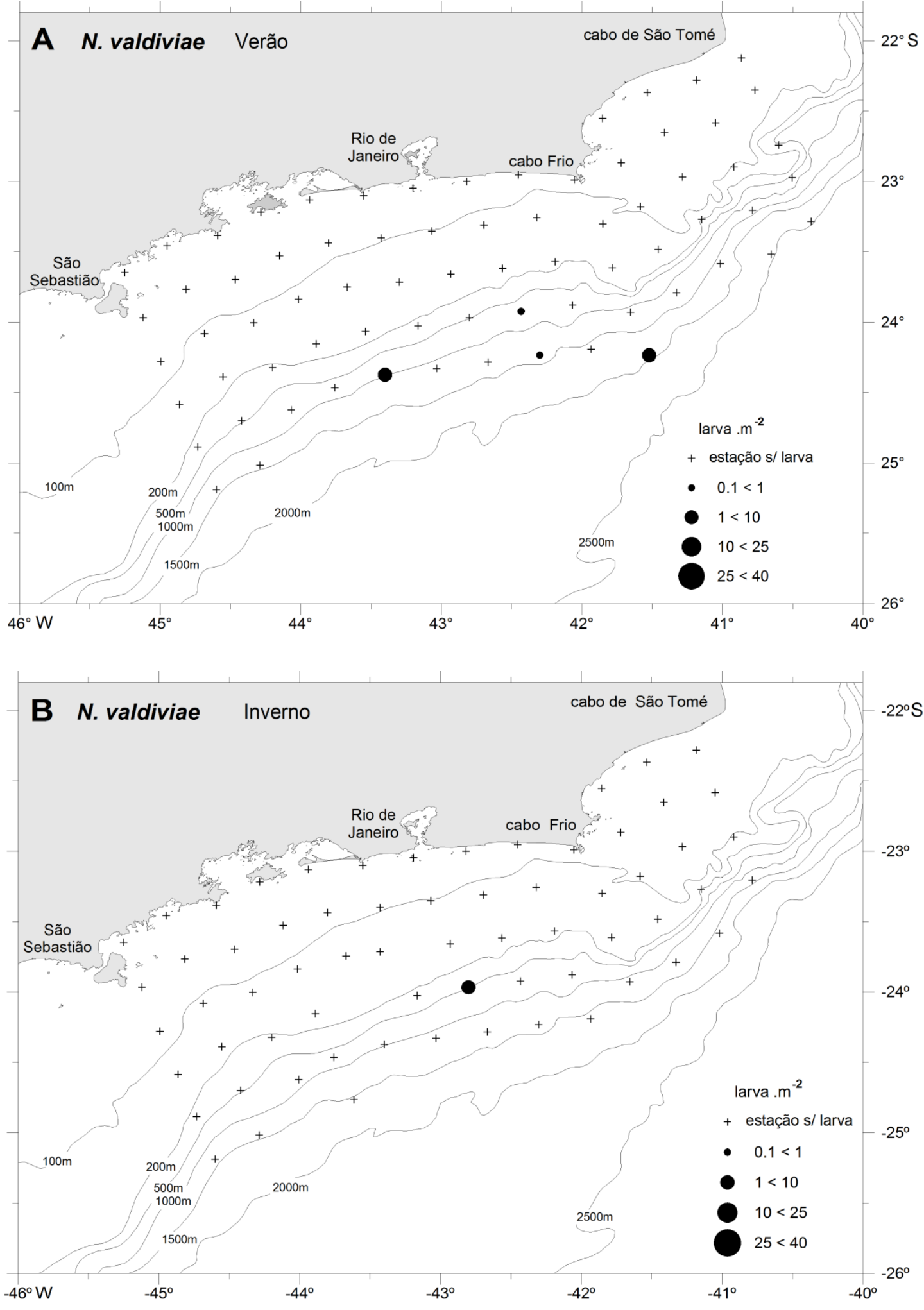

Figura 1.14: Distribuição horizontal e abundância das larvas de Notolychnus valdiviae. entre cabo de São Tomé e ilha de São Sebastião durante o verão (A) e o inverno (B) de 2002. 

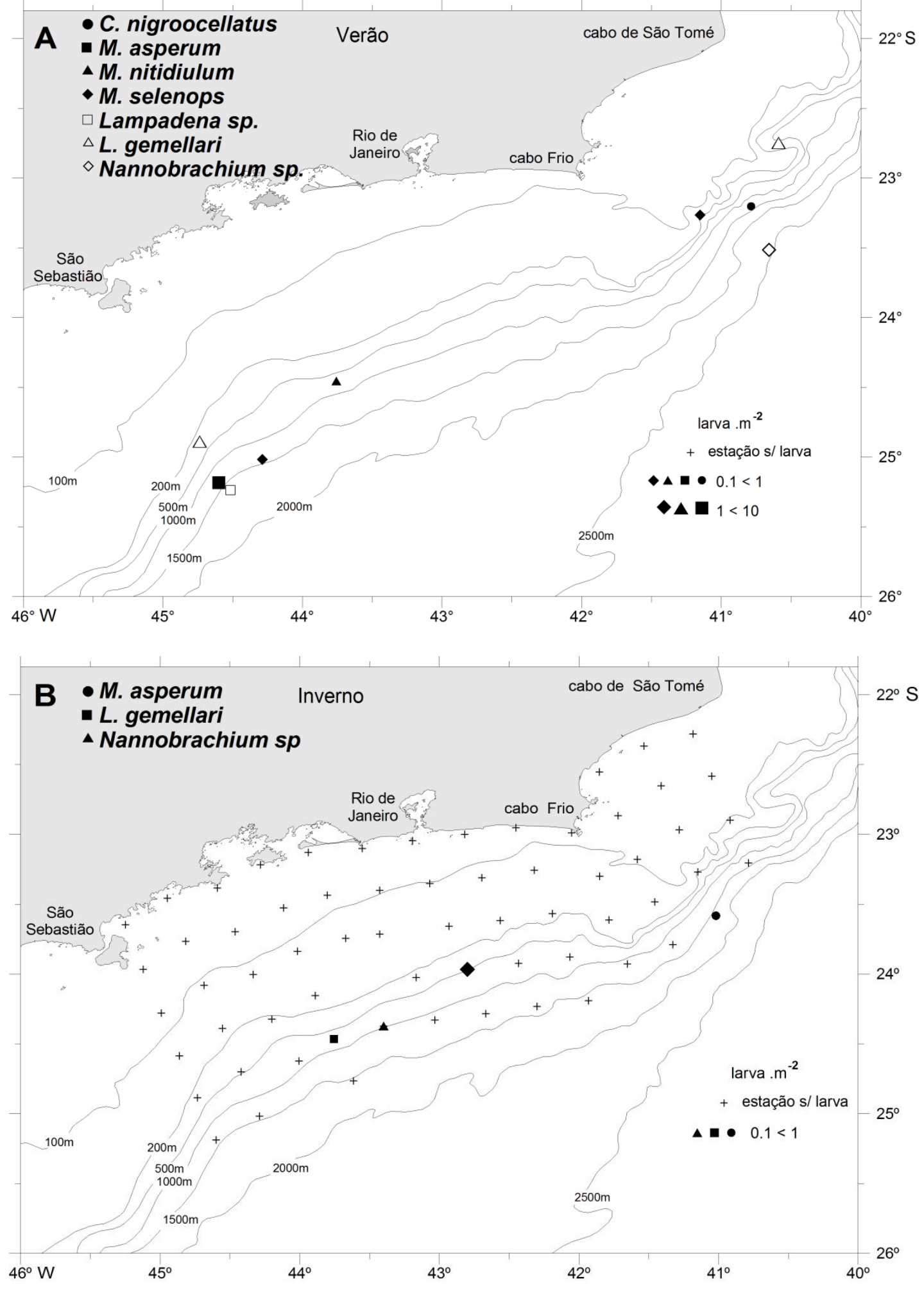

Figura 1.15: Distribuição horizontal e abundância das larvas de Centrobranchus nigroocellatus, Myctophum asperum, M. nitidulum, M. selenops, Lampadena sp., Lobianchia gemellari e Nannobrachium sp. entre cabo de São Tomé e ilha de São Sebastião durante o verão (A) e o inverno (B) de 2002. 

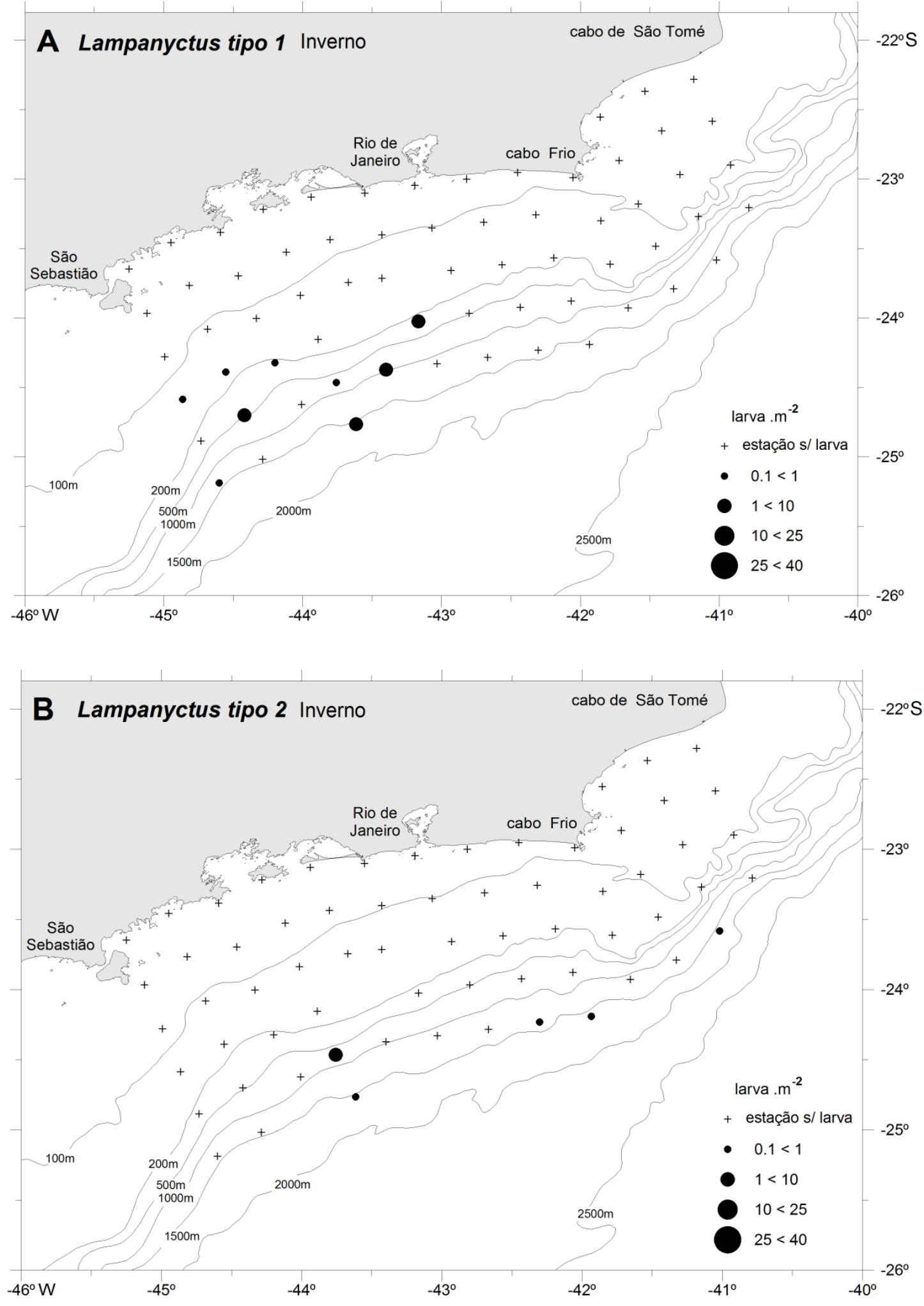

Figura 1.16: Distribuição horizontal e abundância das larvas de Lampanyctus tipos 1 (A) e Lampanyctus tipo 2 (B) entre cabo de São Tomé e ilha de São Sebastião durante o inverno de 2002. 


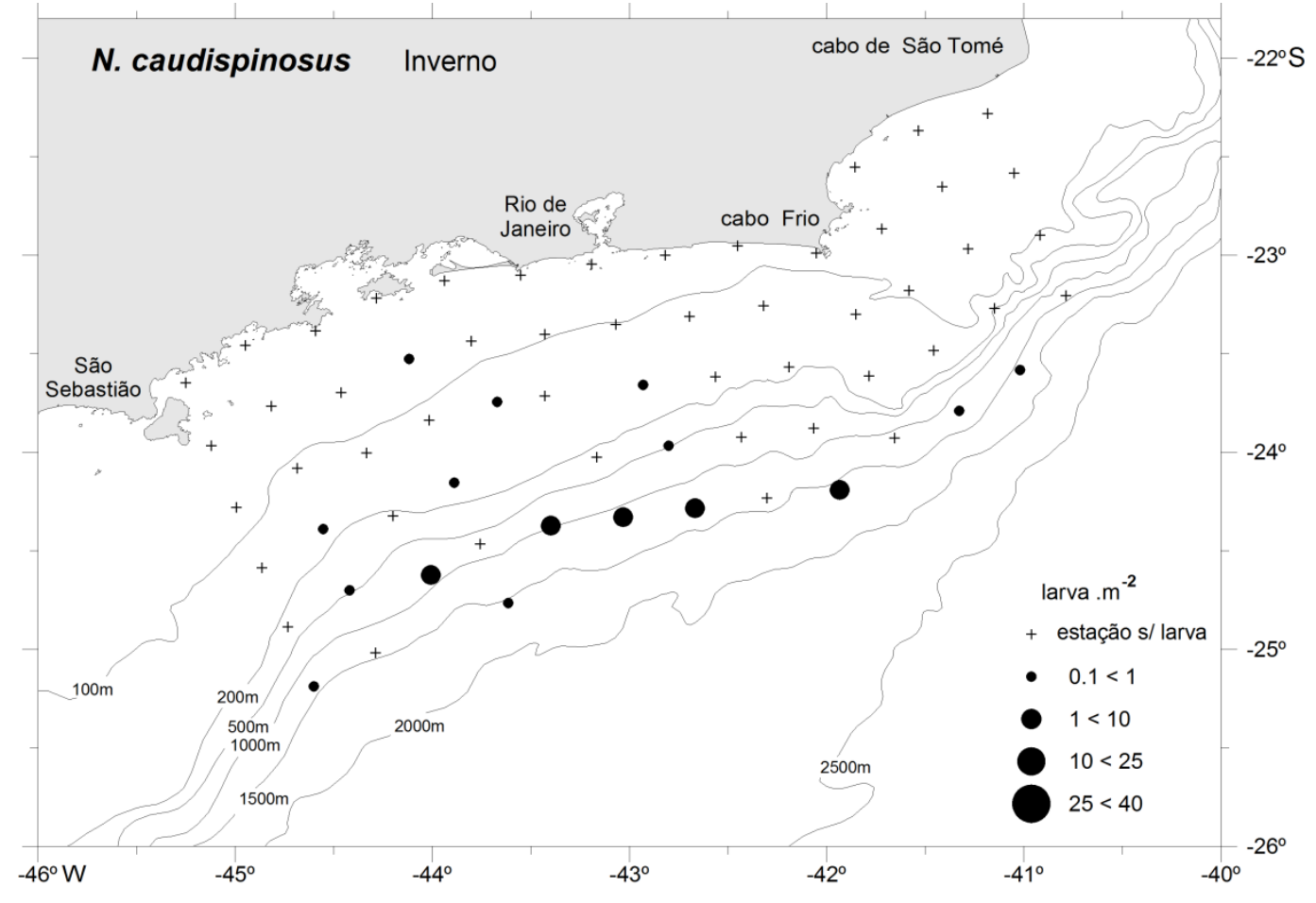

Figura 1.17: Distribuição horizontal e abundância das larvas de Notoscopelus caudispinosus entre cabo de São Tomé e ilha de São Sebastião durante o inverno de 2002.

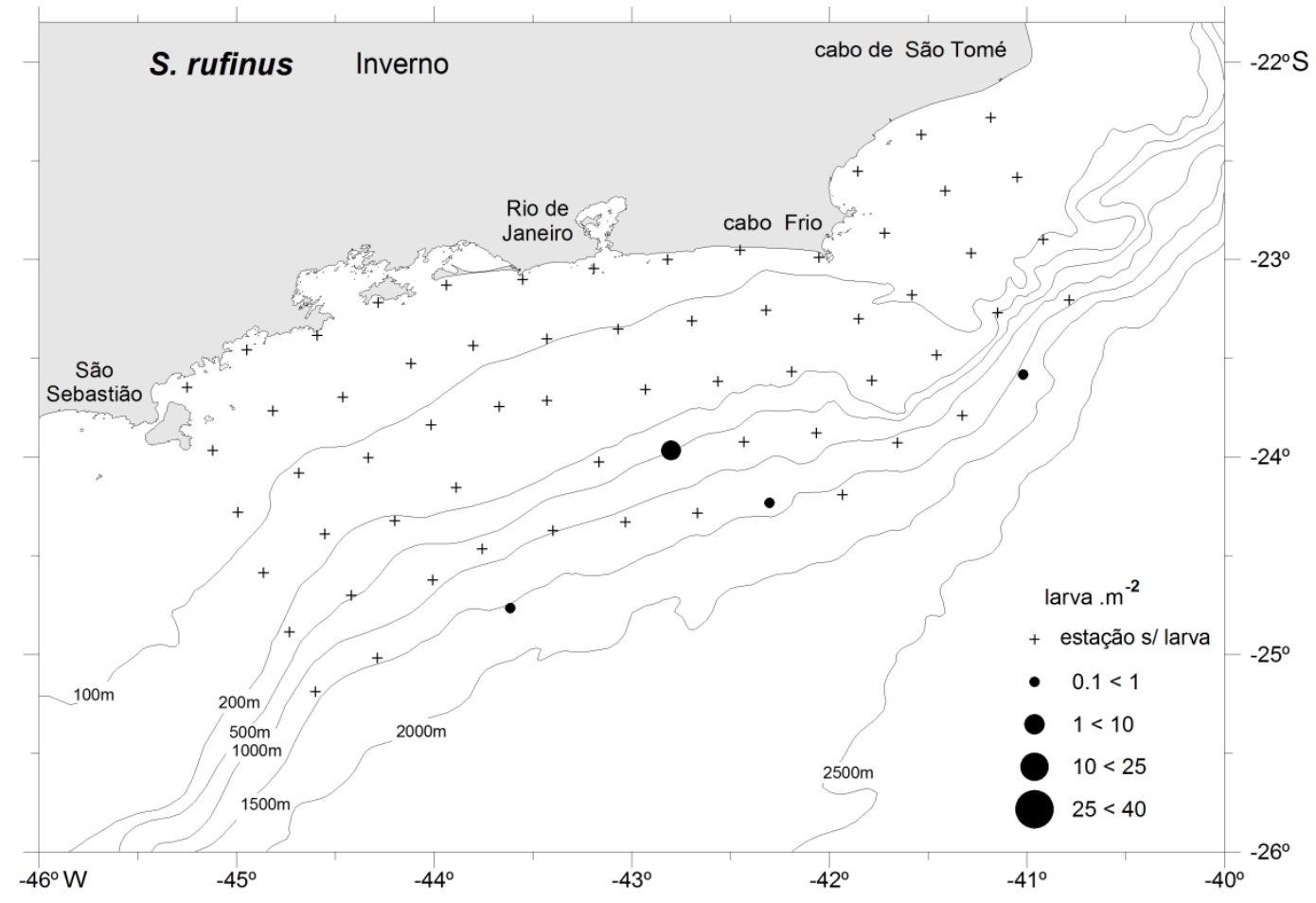

Figura 1.18: Distribuição horizontal e abundância das larvas de Symbolophorus rufinus entre cabo de São Tomé e ilha de São Sebastião durante o inverno de 2002. 

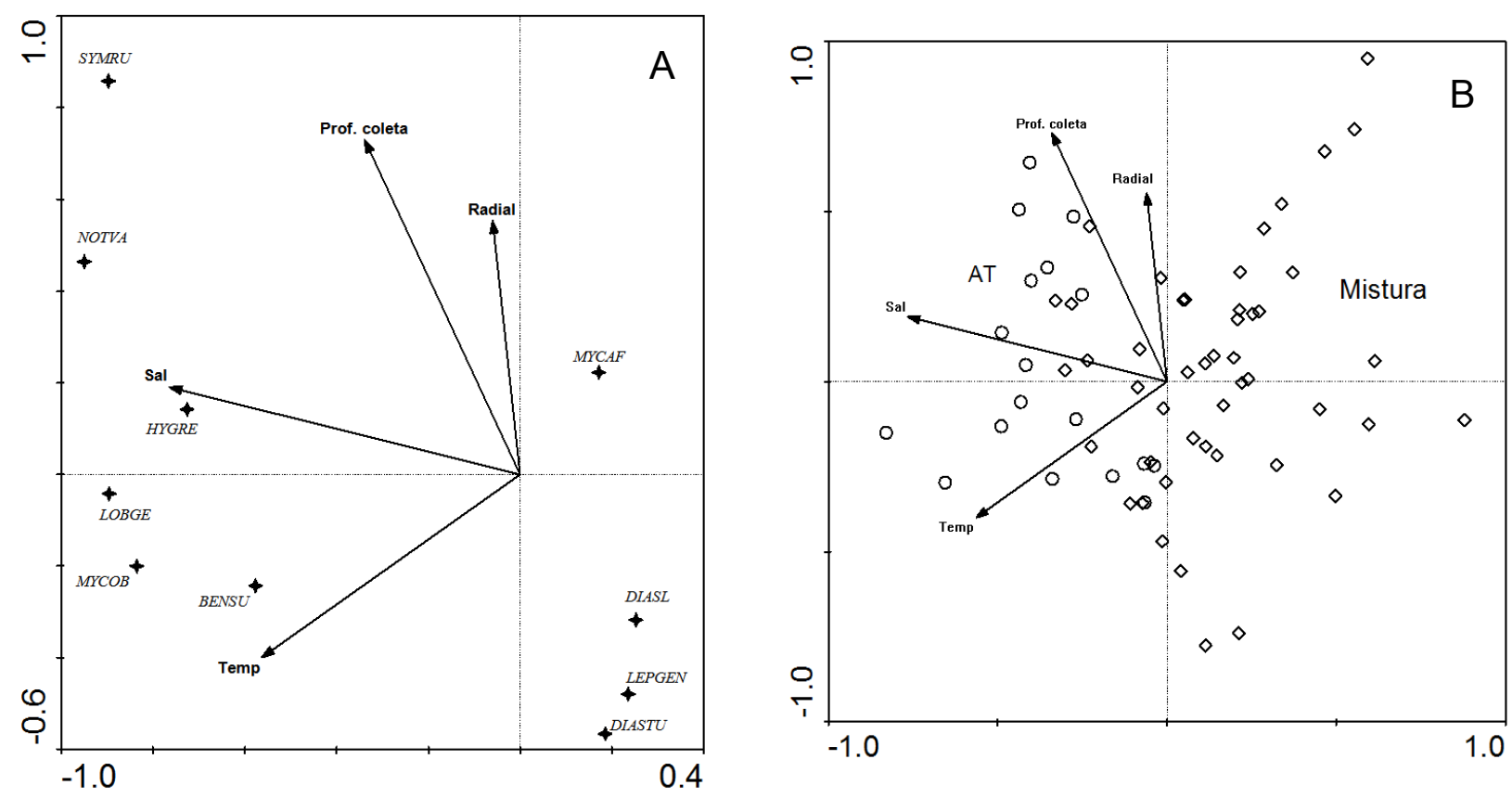

Figura 1.19: Diagramas de ordenação da análise de correspondência canônica com as variáveis ambientais (vetores) e espécies de Myctophidae (A) e amostras (B), coletadas entre cabo de São Tomé e ilha de São Sebastião durante o verão de 2002. Código das espécies: BENSU, Benthosema suborbitale; DIASL, Diaphus tipo slender; DIASTU, Diaphus tipo stubby; HYGRE, Hygophum reinhardtii; LEPGE, Lepidophanes guentheri; LOBGE, Lobianchia gemellarii; MYCAF, Myctophum affine; MYCOB, M. obtusirostre; NOTVA, Notolychnus valdiviae; SYMRU, Symbolophorus rufinus. 

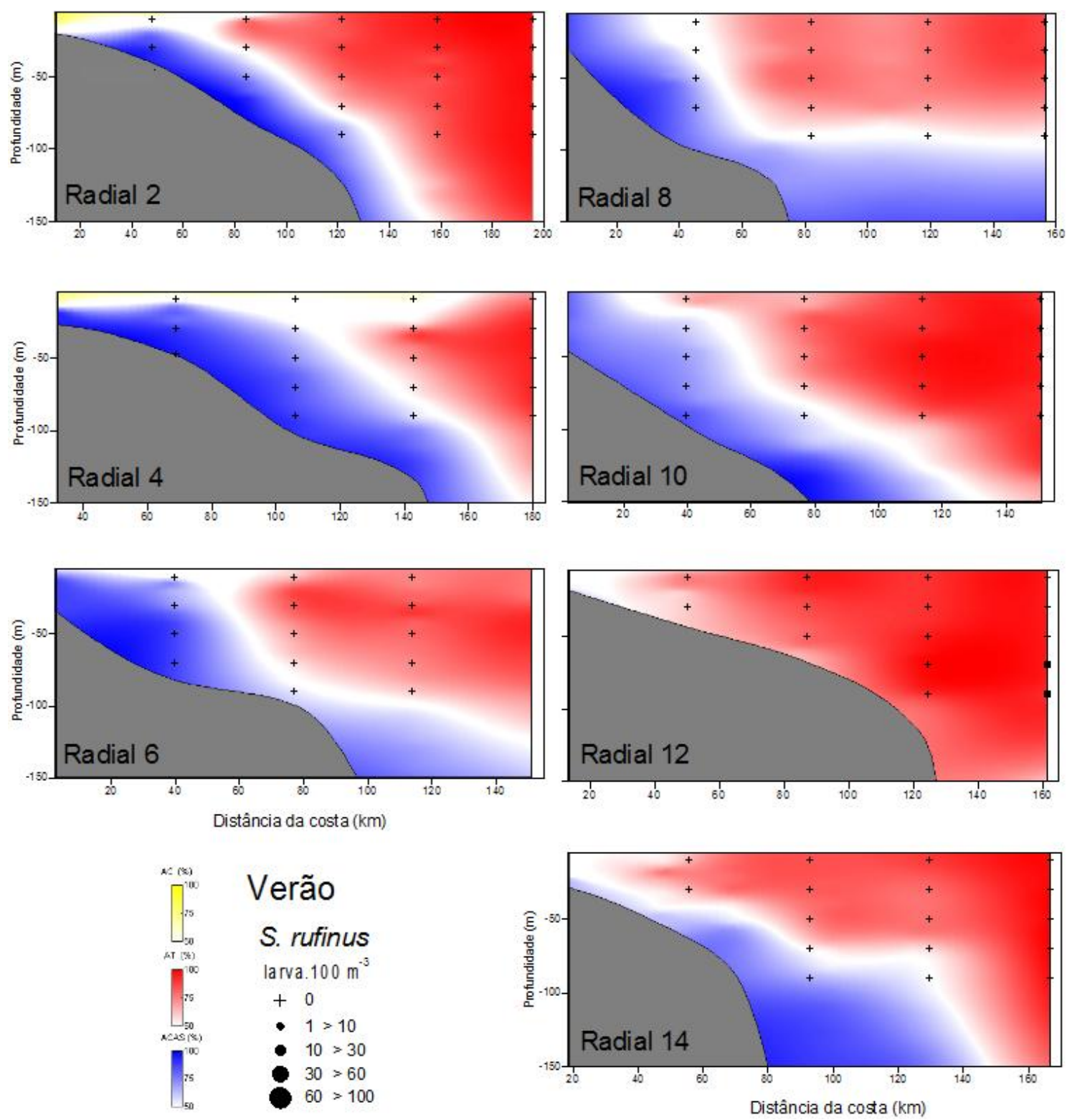

Figura 1.20: Distribuição vertical das larvas de Symbolophorus rufinus entre 0-100 m de profundidade em relação à distribuição das porcentagens de massa de água entre cabo de São Tomé e ilha de São Sebastião durante o verão de 2002. 

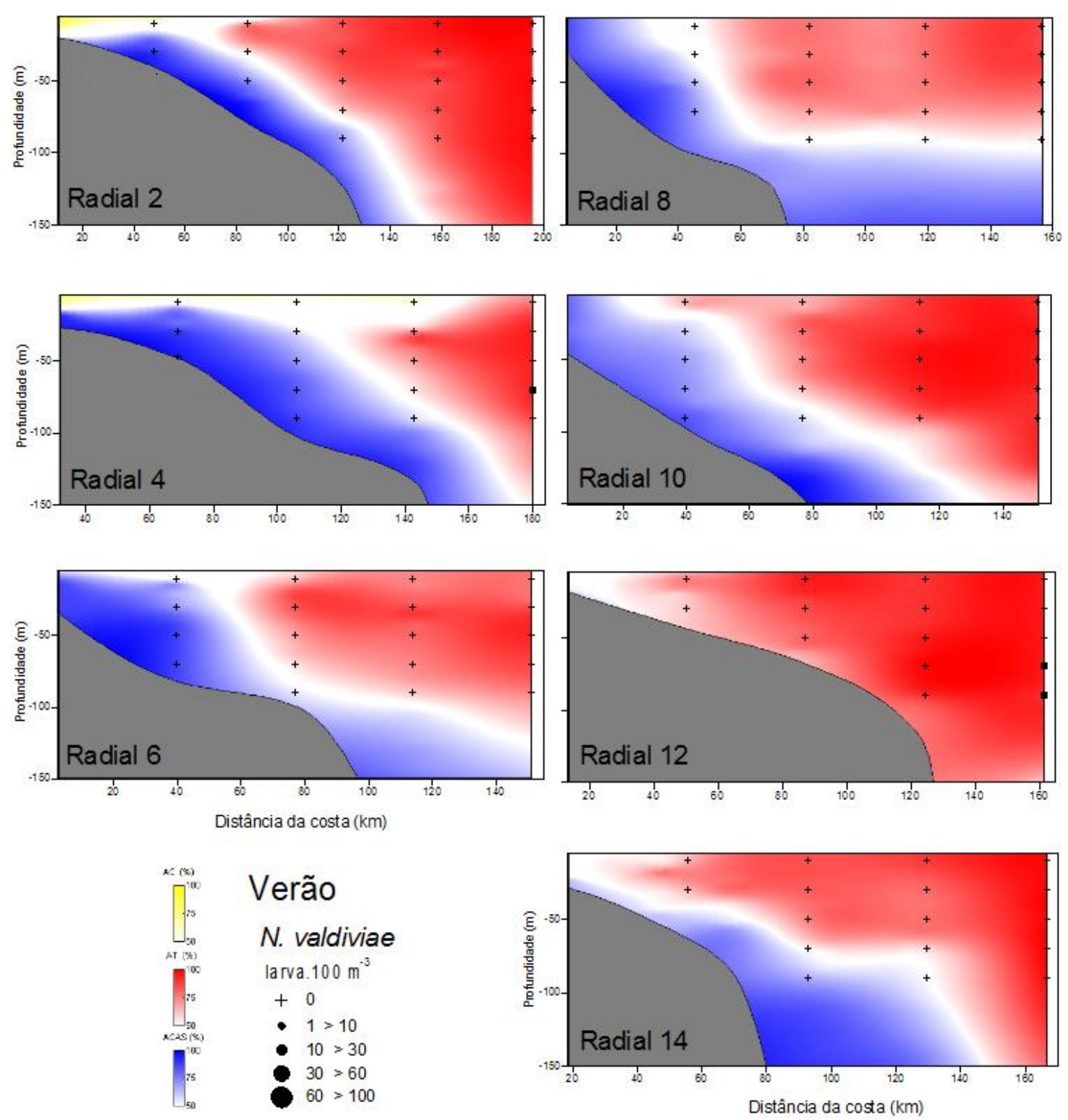

Figura 1.21: Distribuição vertical das larvas de Notolychnus valdiviae entre 0-100 m de profundidade em relação à distribuição das porcentagens de massa de água entre cabo de São Tomé e ilha de São Sebastião durante o verão de 2002. 

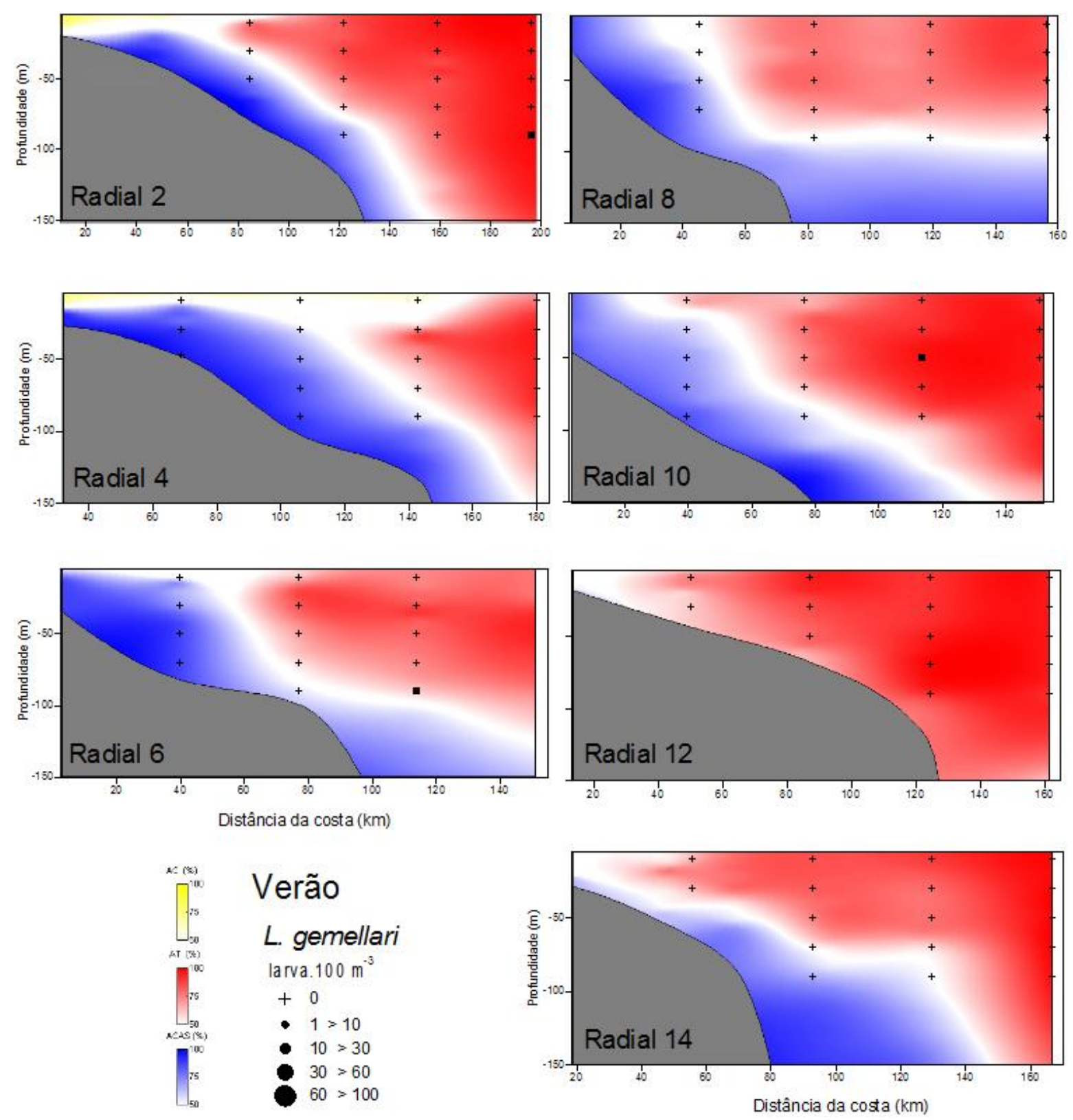

Figura 1.22: Distribuição vertical das larvas de Lobianchia gemellari entre 0-100 m de profundidade em relação à distribuição das porcentagens de massa de água entre cabo de São Tomé e ilha de São Sebastião durante o verão de 2002. 

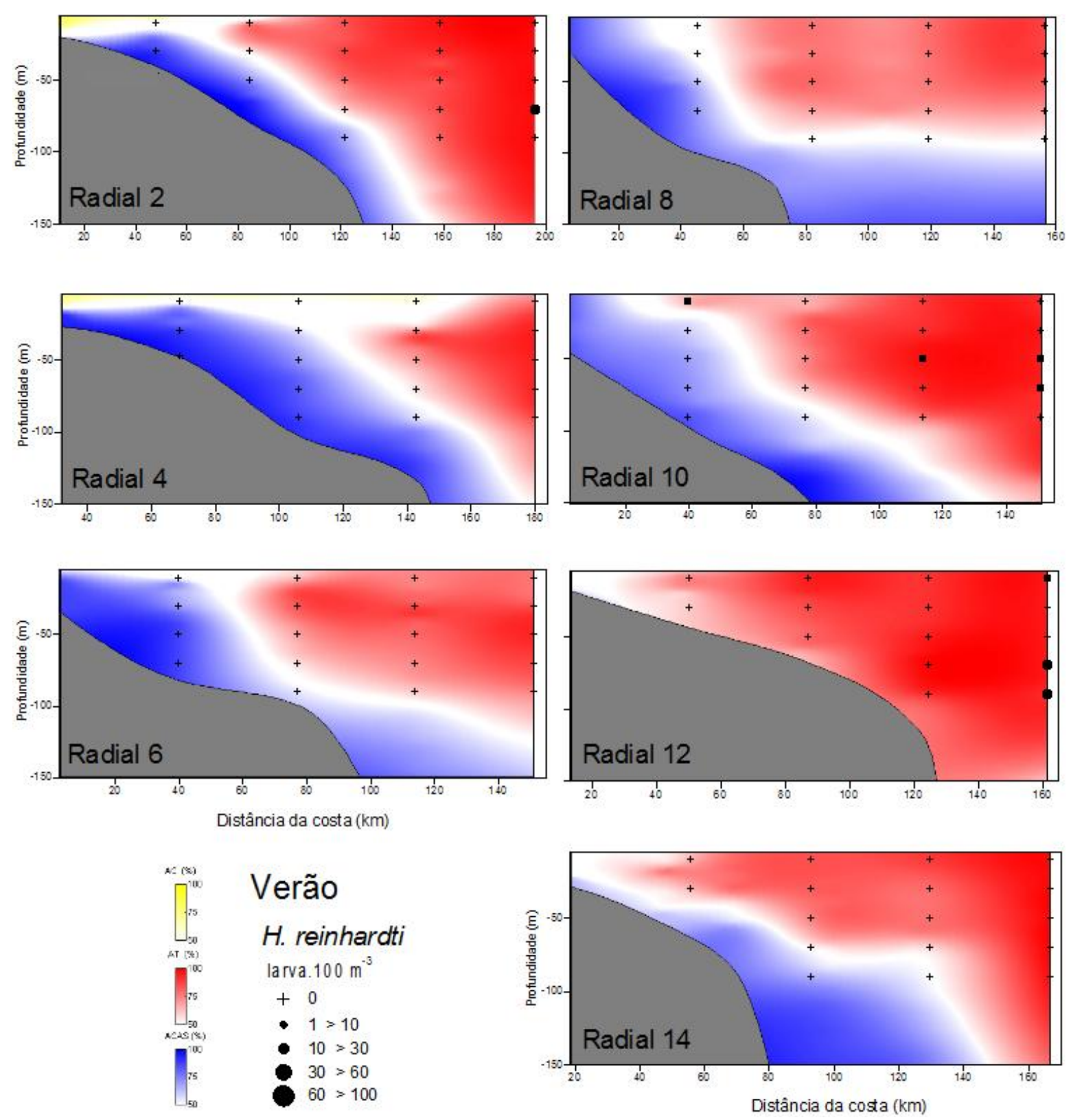

Figura 1.23: Distribuição vertical das larvas de Hygophum reinhardti entre 0-100 m de profundidade em relação à distribuição das porcentagens de massa de água entre cabo de São Tomé e ilha de São Sebastião durante o verão de 2002. 

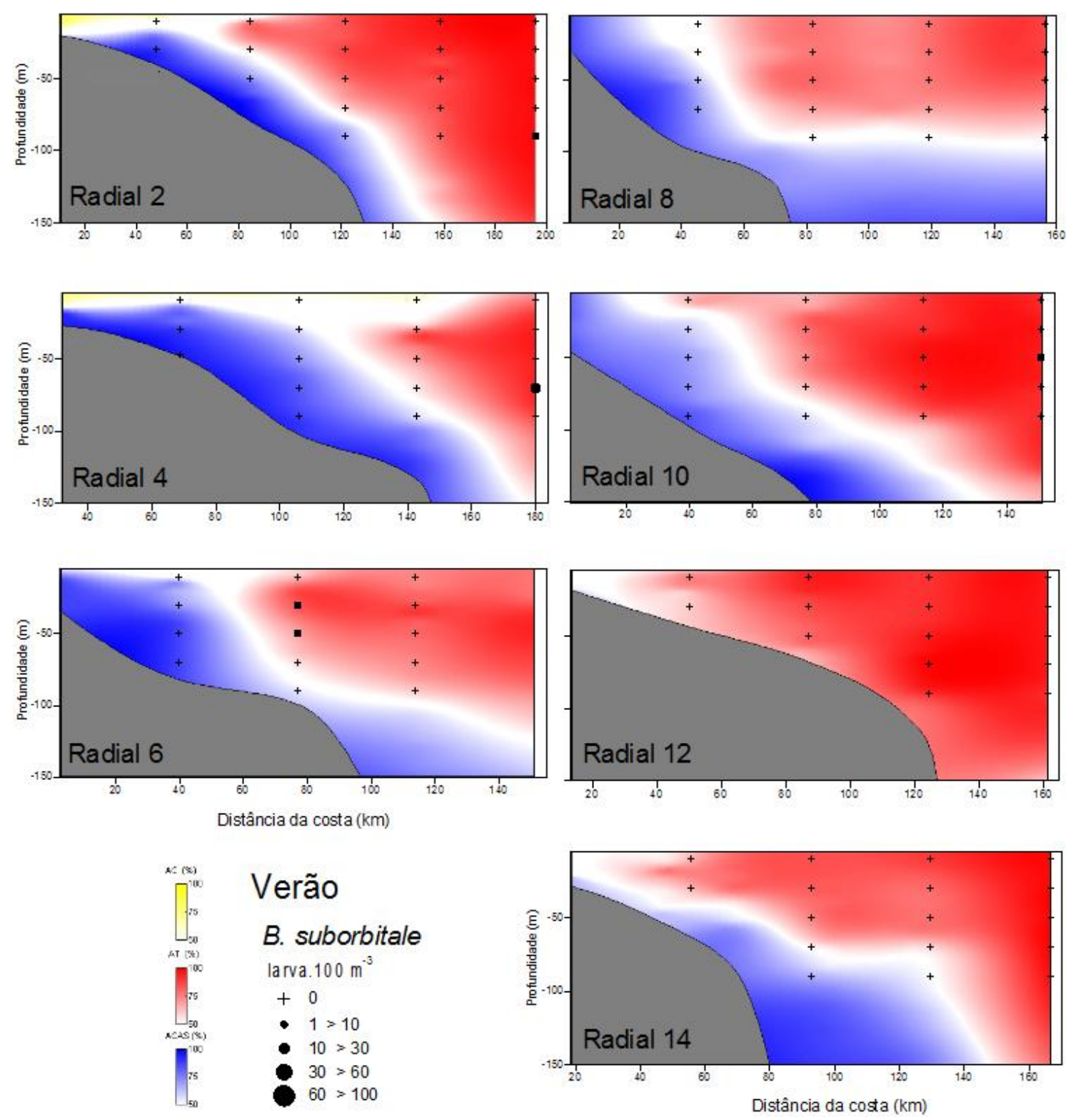

Figura 1.24: Distribuição vertical das larvas de Benthosema suborbitale entre 0-100 m de profundidade em relação à distribuição das porcentagens de massa de água entre cabo de São Tomé e ilha de São Sebastião durante o verão de 2002. 

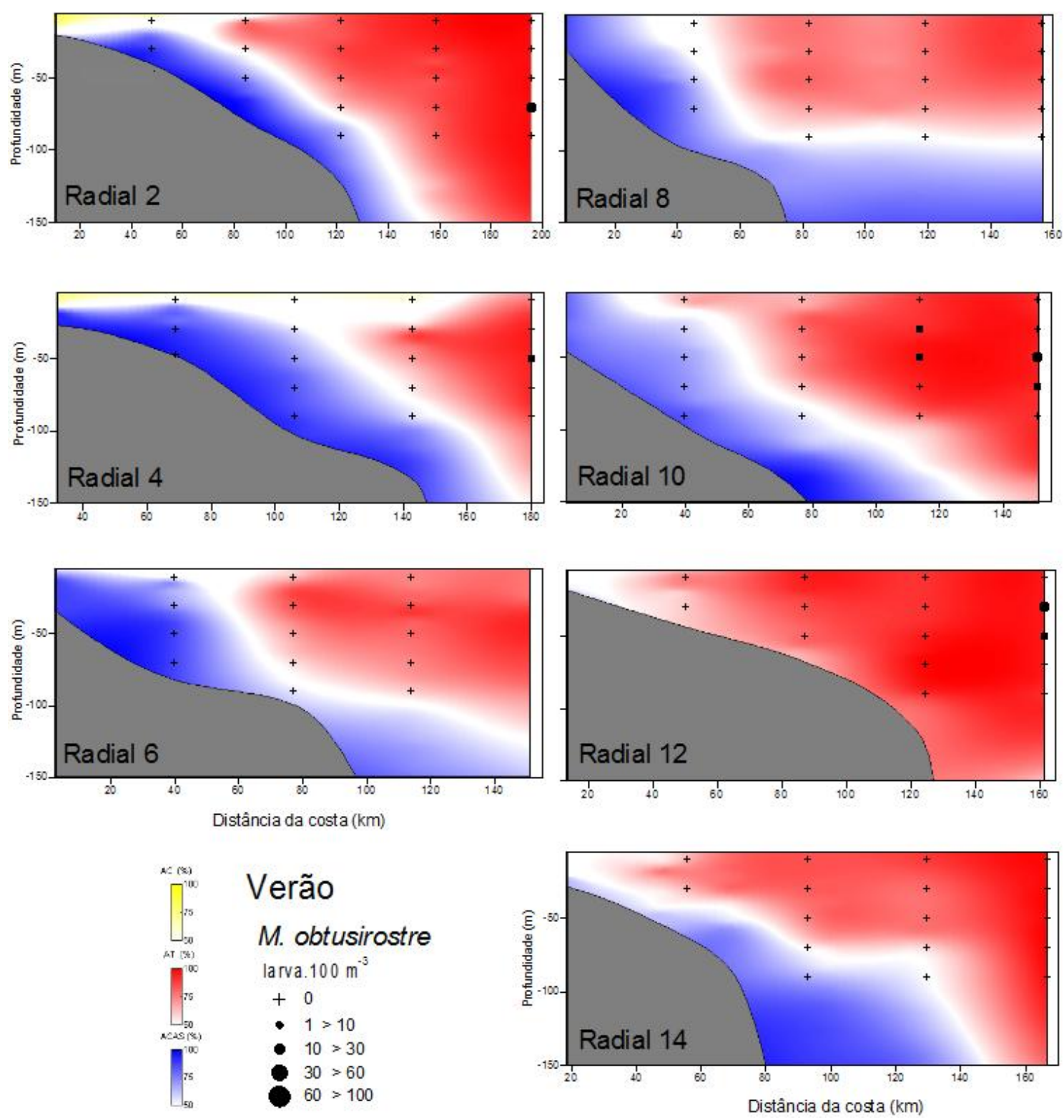

Figura 1.25: Distribuição vertical das larvas de Myctophum obtusirostre entre 0-100 m de profundidade em relação à distribuição das porcentagens de massa de água entre cabo de São Tomé e ilha de São Sebastião durante o verão de 2002. 

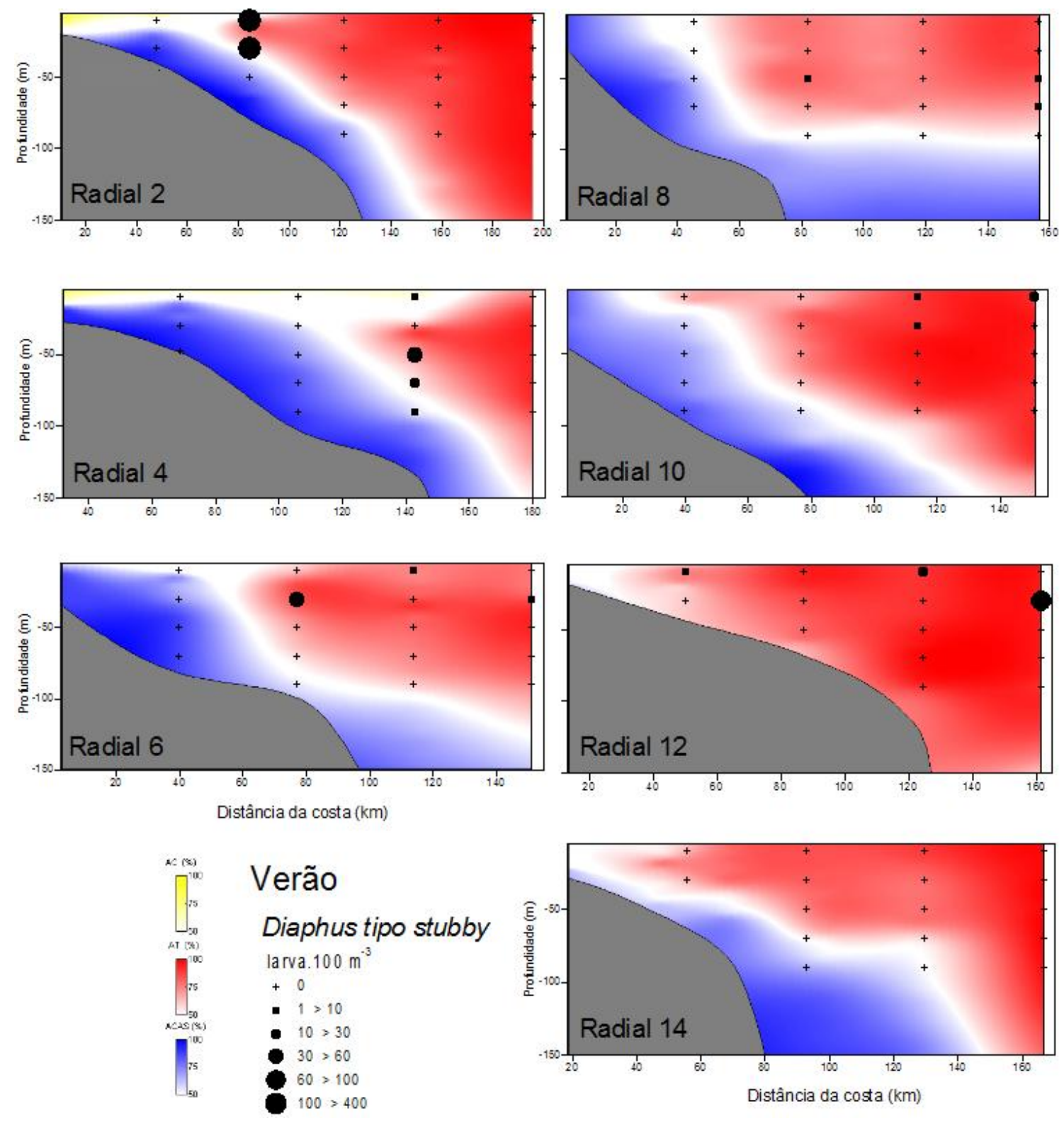

Figura 1.26: Distribuição vertical das larvas de Diaphus tipo stubby entre 0-100 m de profundidade em relação à distribuição das porcentagens de massa de água entre cabo de São Tomé e ilha de São Sebastião durante o verão de 2002. 

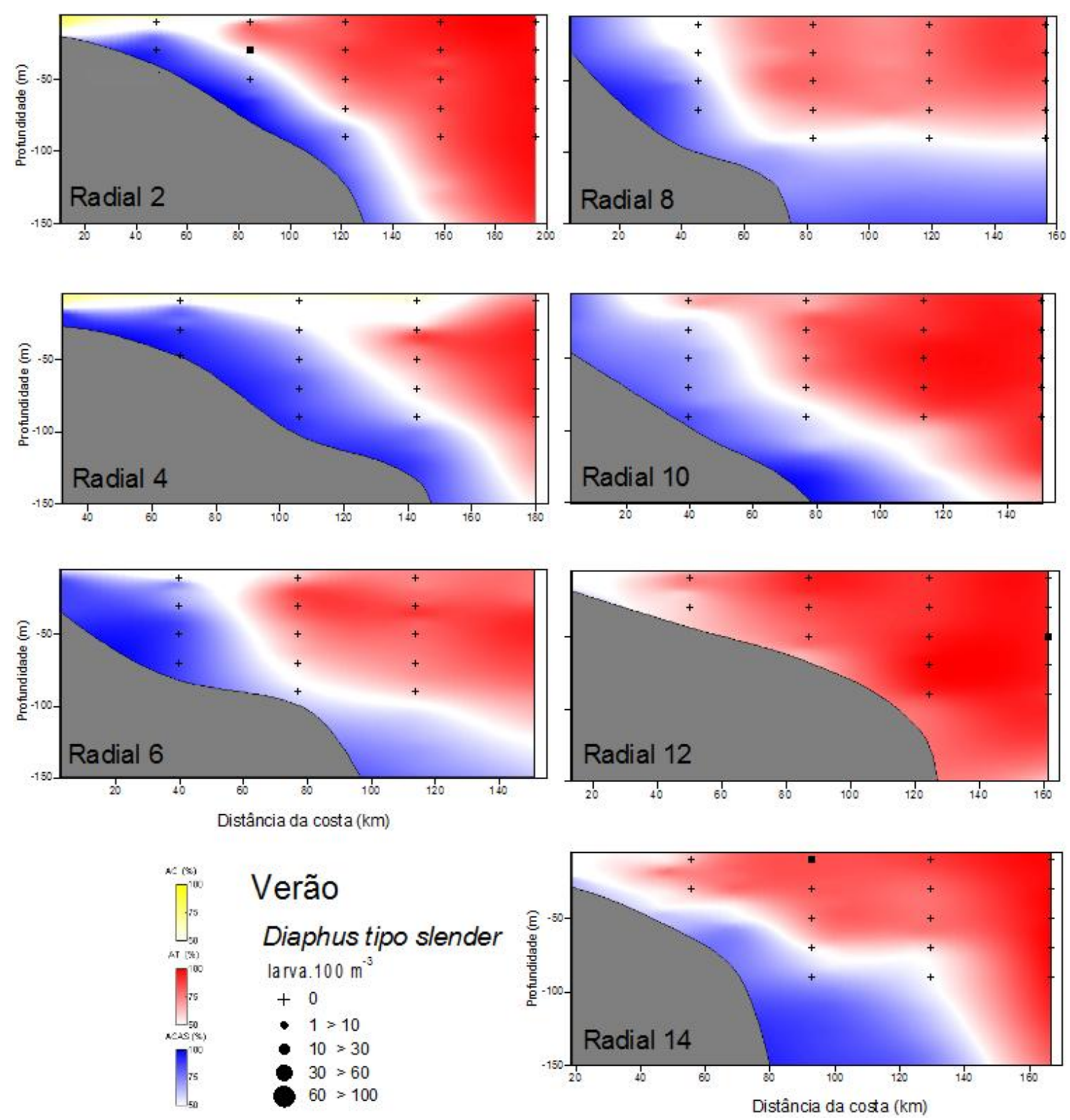

Figura 1.27: Distribuição vertical das larvas de Diaphus tipo slender entre 0-100 m de profundidade em relação à distribuição das porcentagens de massa de água entre cabo de São Tomé e ilha de São Sebastião durante o verão de 2002. 

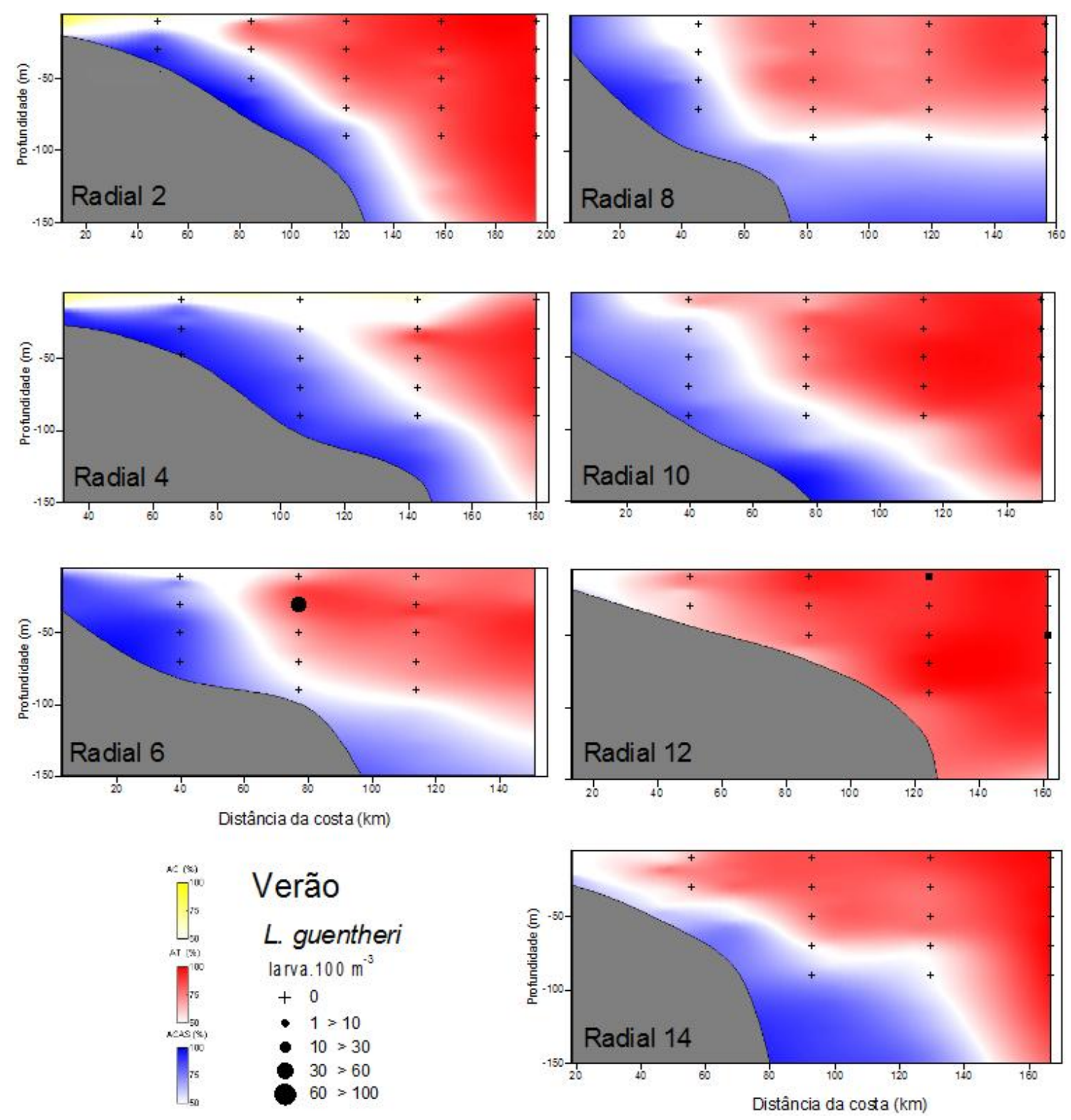

Figura 1.28: Distribuição vertical das larvas de Lepidophanes guentheri entre 0-100 m de profundidade em relação à distribuição das porcentagens de massa de água entre cabo de São Tomé e ilha de São Sebastião durante o verão de 2002. 

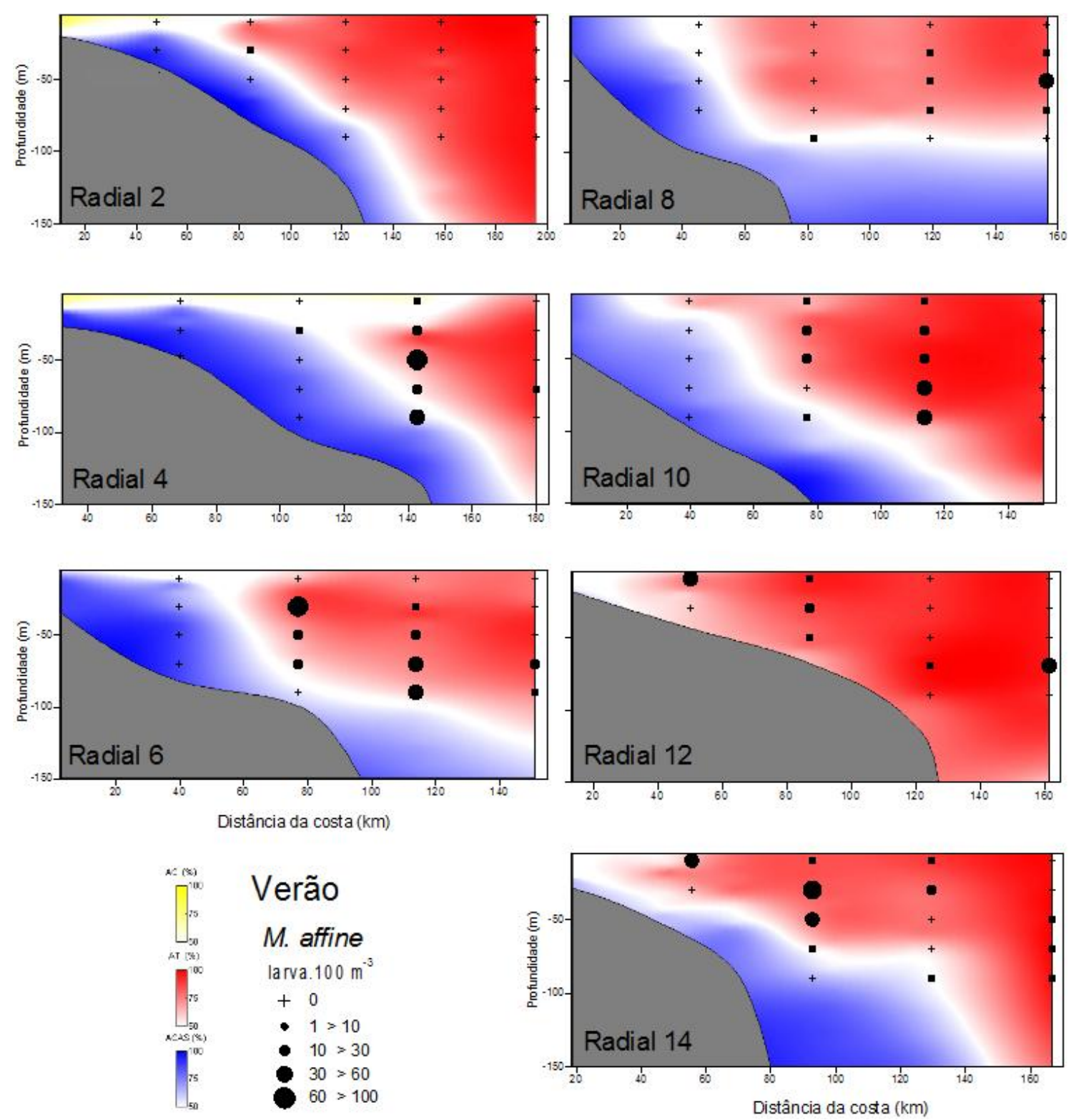

Figura 1.29: Distribuição vertical das larvas de Myctophum affine entre $0-100 \mathrm{~m}$ de profundidade em relação à distribuição das porcentagens de massa de água entre cabo de São Tomé e ilha de São Sebastião durante o verão de 2002. 

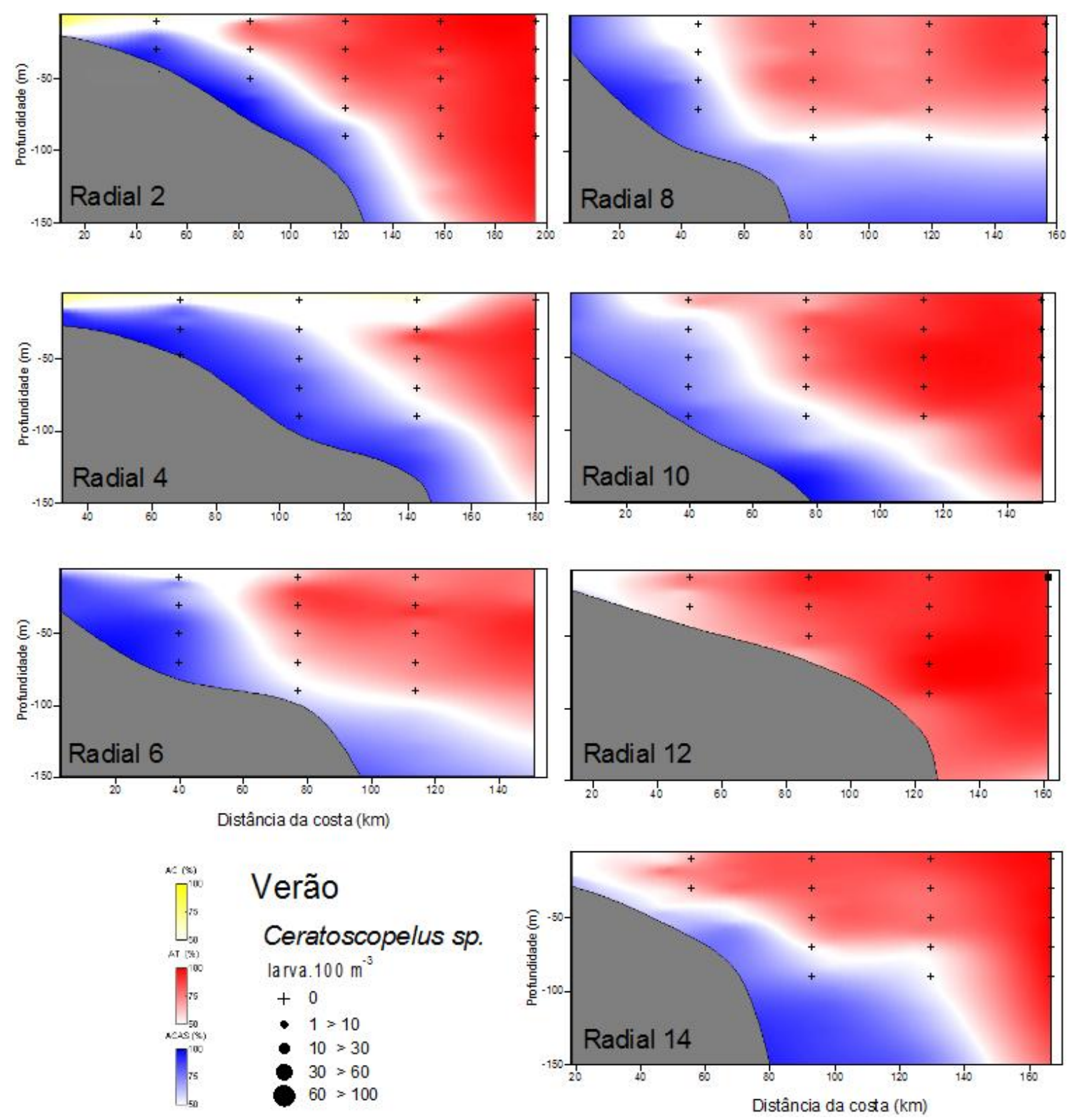

Figura 1.30: Distribuição vertical das larvas de Ceratoscopelus $s p$. entre $0-100 \mathrm{~m}$ de profundidade em relação à distribuição das porcentagens de massa de água entre cabo de São Tomé e ilha de São Sebastião durante o verão de 2002. 

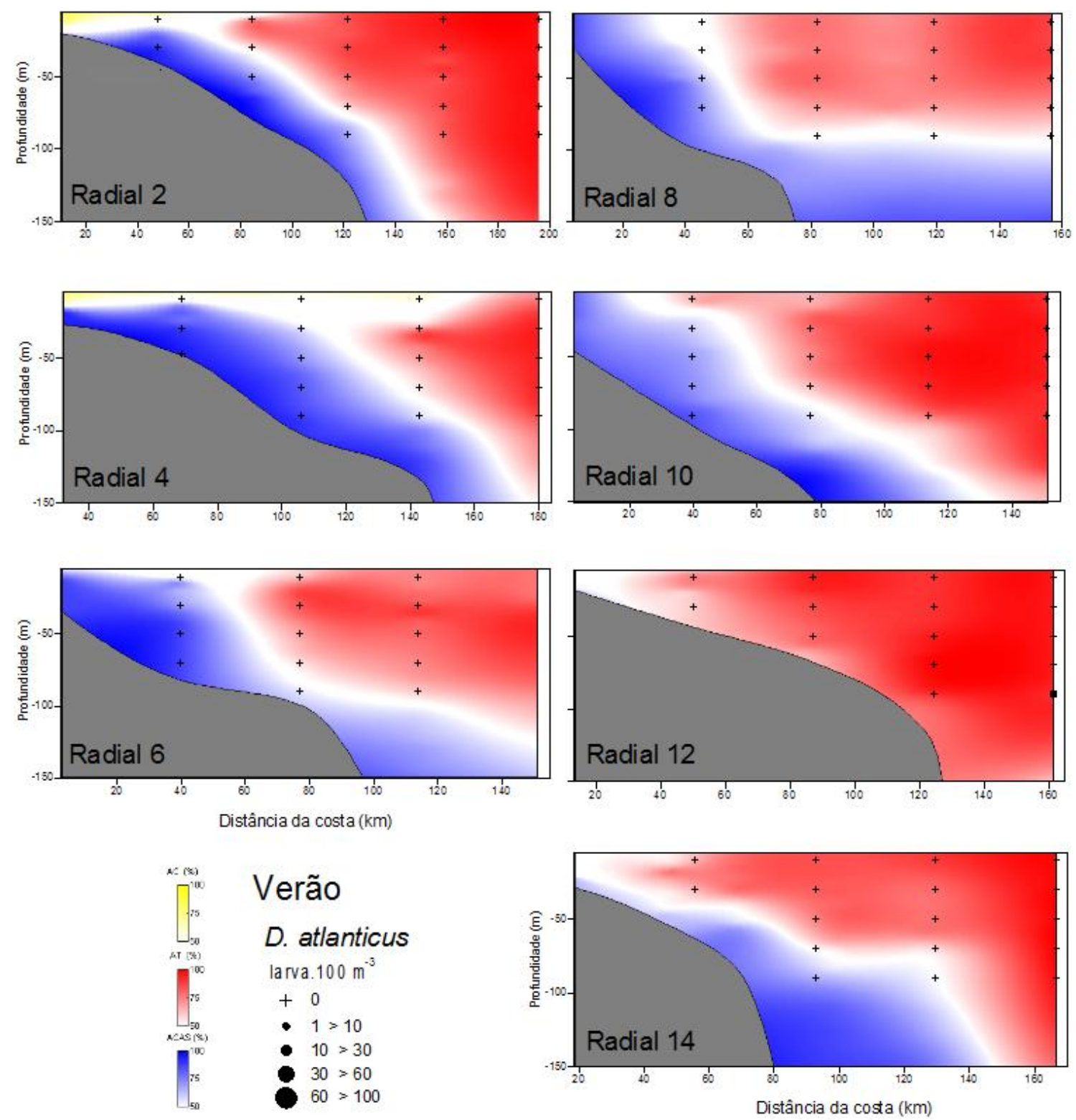

Figura 1.31: Distribuição vertical das larvas de Diogenichthys atlanticus entre 0-100 m de profundidade em relação à distribuição das porcentagens de massa de água entre cabo de São Tomé e ilha de São Sebastião durante o verão de 2002. 

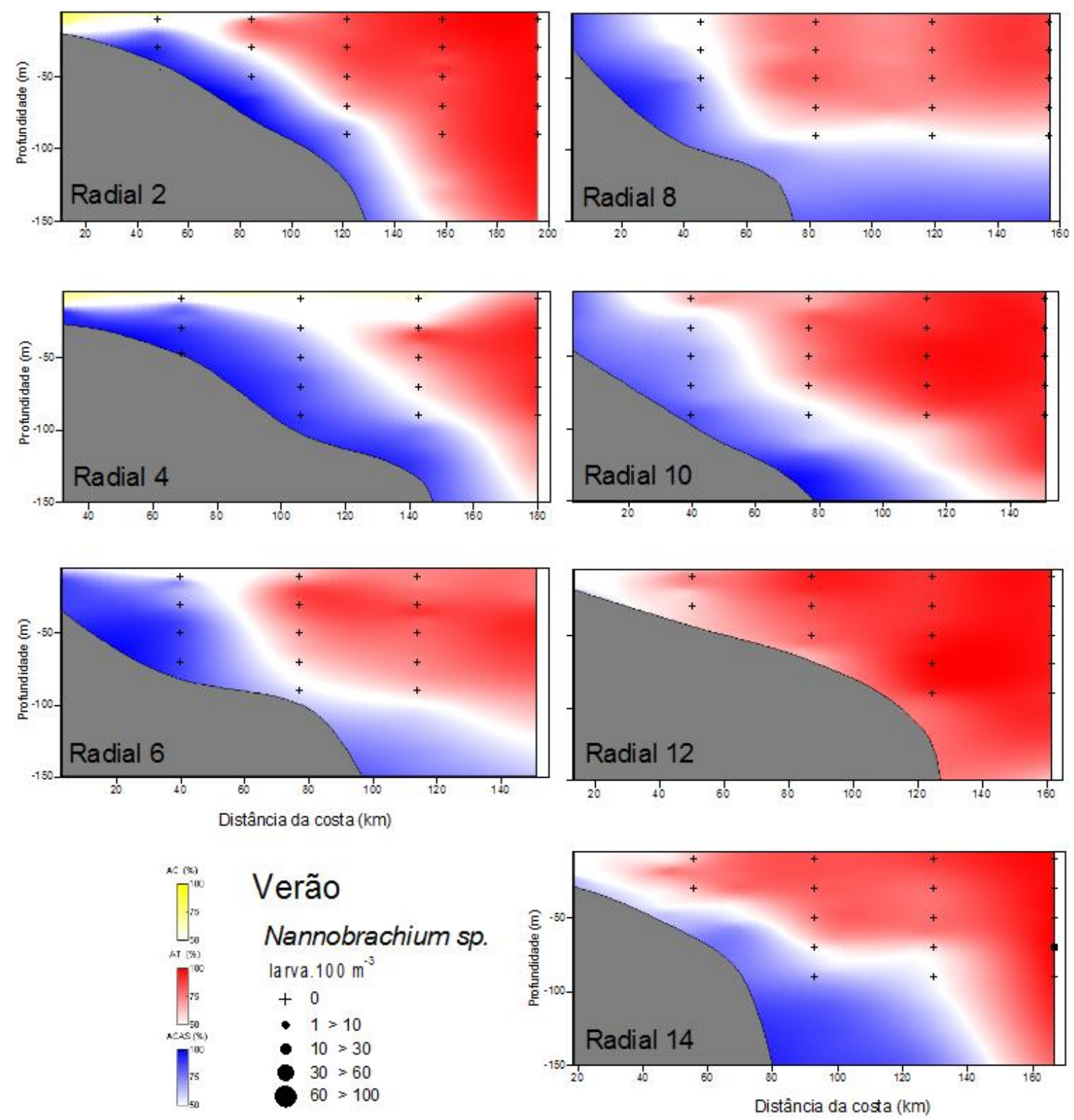

Figura 1.32: Distribuição vertical das larvas de Nannobrachium $s p$. entre $0-100 \mathrm{~m}$ de profundidade em relação à distribuição das porcentagens de massa de água entre cabo de São Tomé e ilha de São Sebastião durante o verão de 2002. 

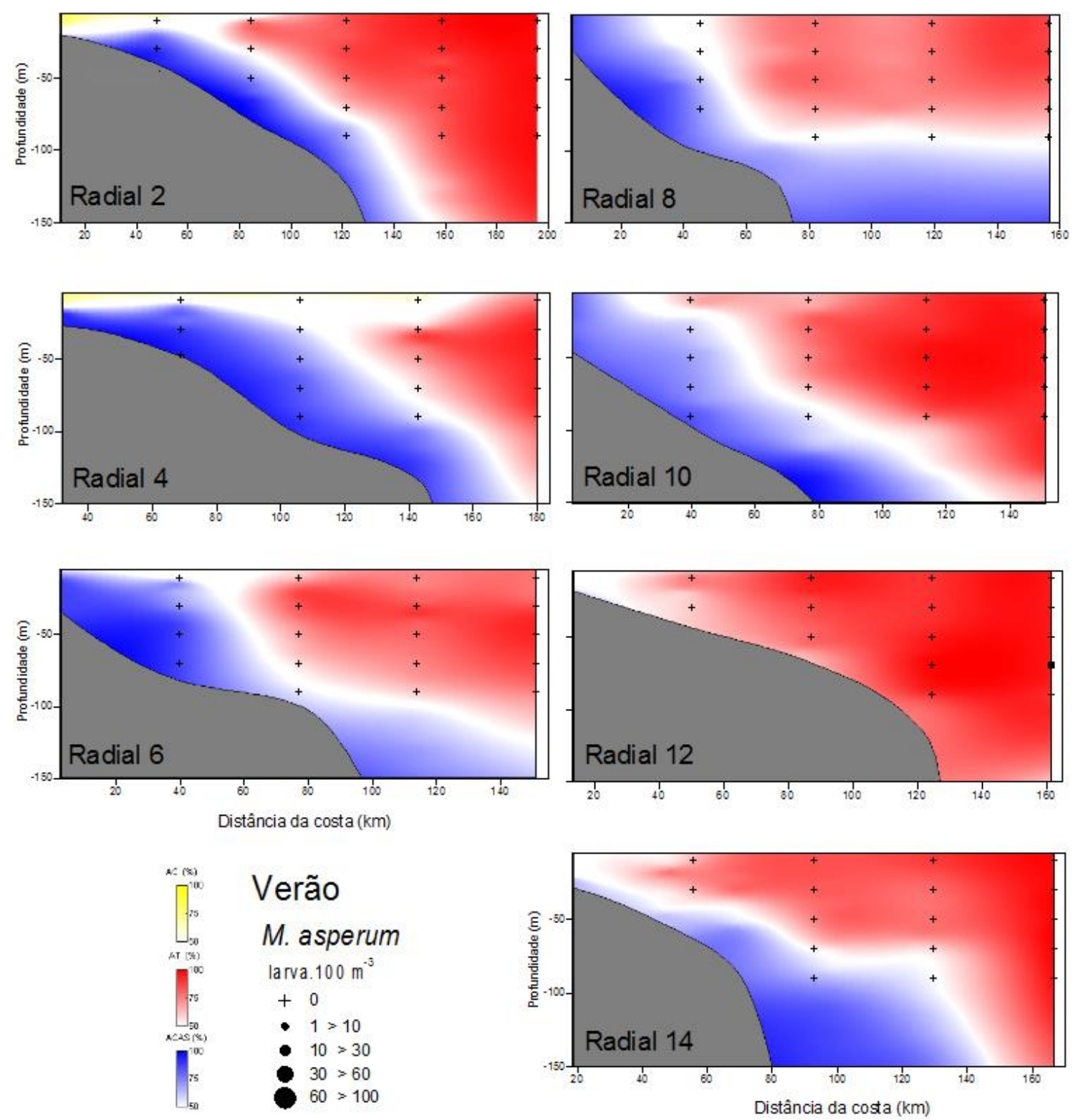

Figura 1.33: Distribuição vertical das larvas de Myctophum asperum entre 0-100 m de profundidade em relação à distribuição das porcentagens de massa de água entre cabo de São Tomé e ilha de São Sebastião durante o verão de 2002. 

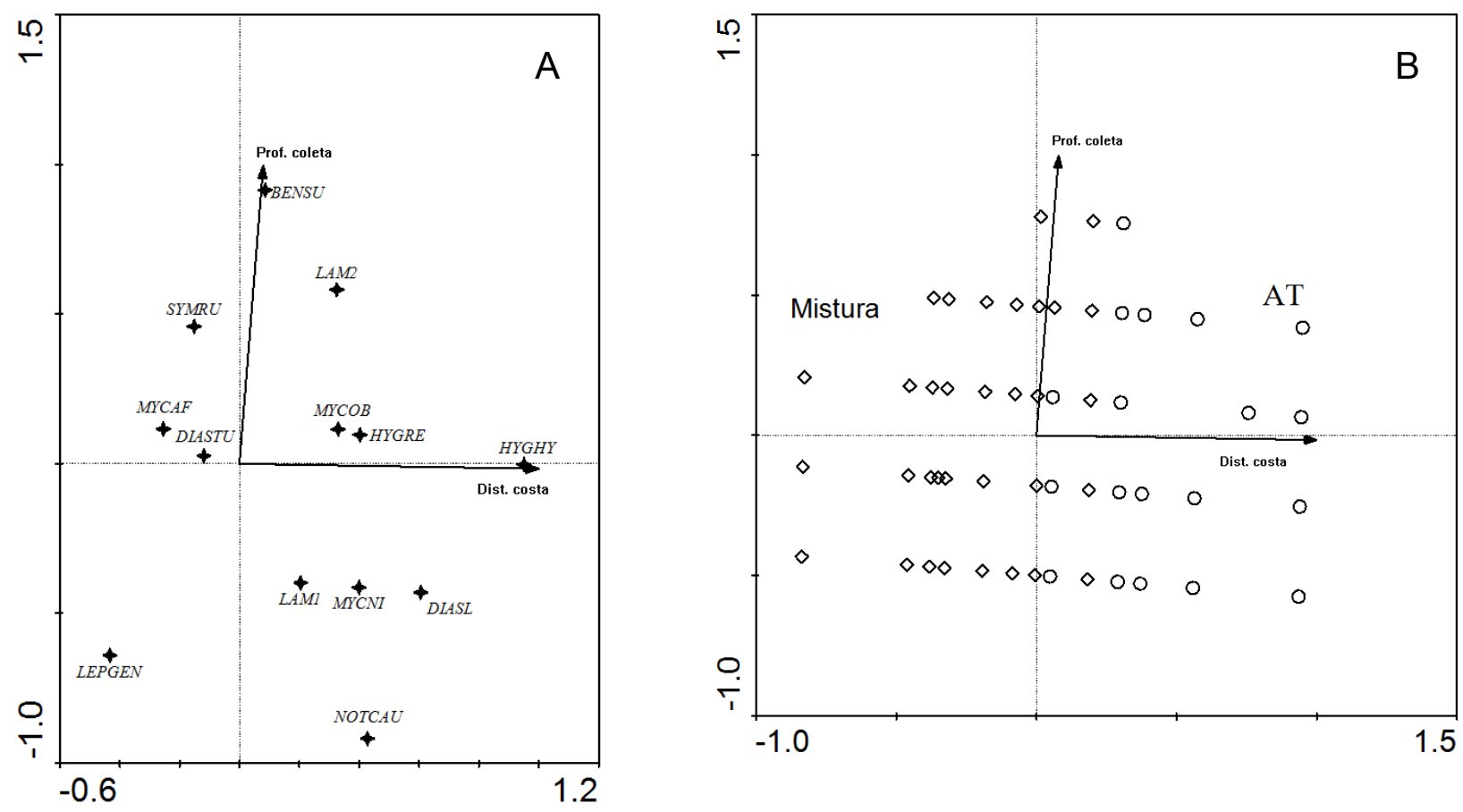

Figura 1.34: Diagramas de ordenação da análise de correspondência canônica com as variáveis ambientais (vetores) e espécies de Myctophidae (A) e amostras (B), coletadas entre cabo de São Tomé e ilha de São Sebastião durante o inverno de 2002. Código das espécies: BENSU, Benthosema suborbitale; DIASL, Diaphus tipo slender; DIASTU, Diaphus tipo stubby; HYGHY, Hygophum hygomii; HYGRE, Hygophum reinhardtii; LAM1, Lampanyctus tipo 1; LAM2, Lampanyctus tipo 2; LEPGE, Lepidophanes guentheri; MYCAF, Myctophum affine; MYCNI, M. nitidulum; MYCOB, M. obtusirostre; NOTCAU, Notoscopelus caudispinosus; SYMRU, Symbolophorus rufinus. 

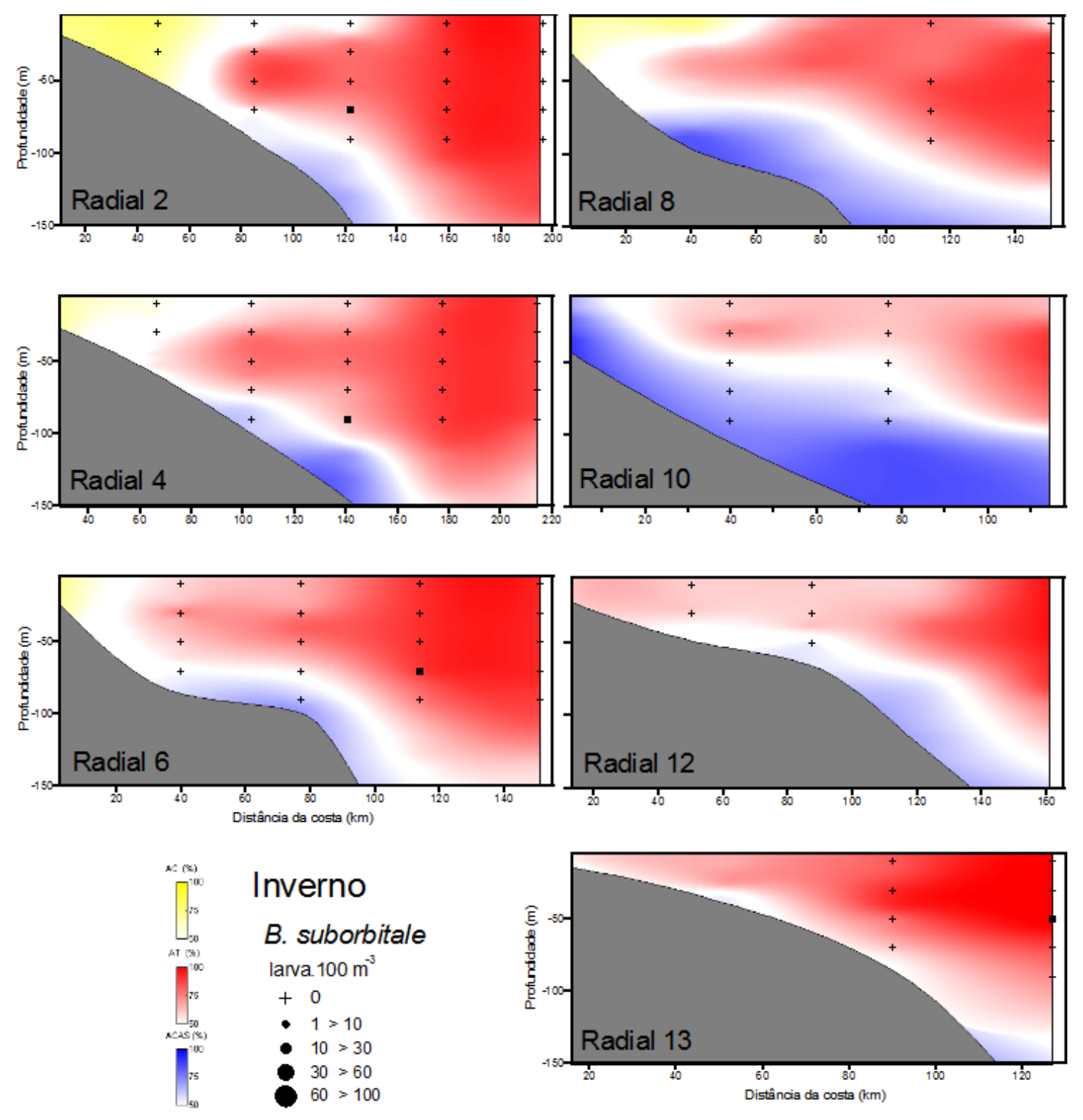

Figura 1.35: Distribuição vertical das larvas de Benthosema suborbitale entre 0-100 m de profundidade em relação à distribuição das porcentagens de massa de água entre cabo de São Tomé e ilha de São Sebastião durante o inverno de 2002. 

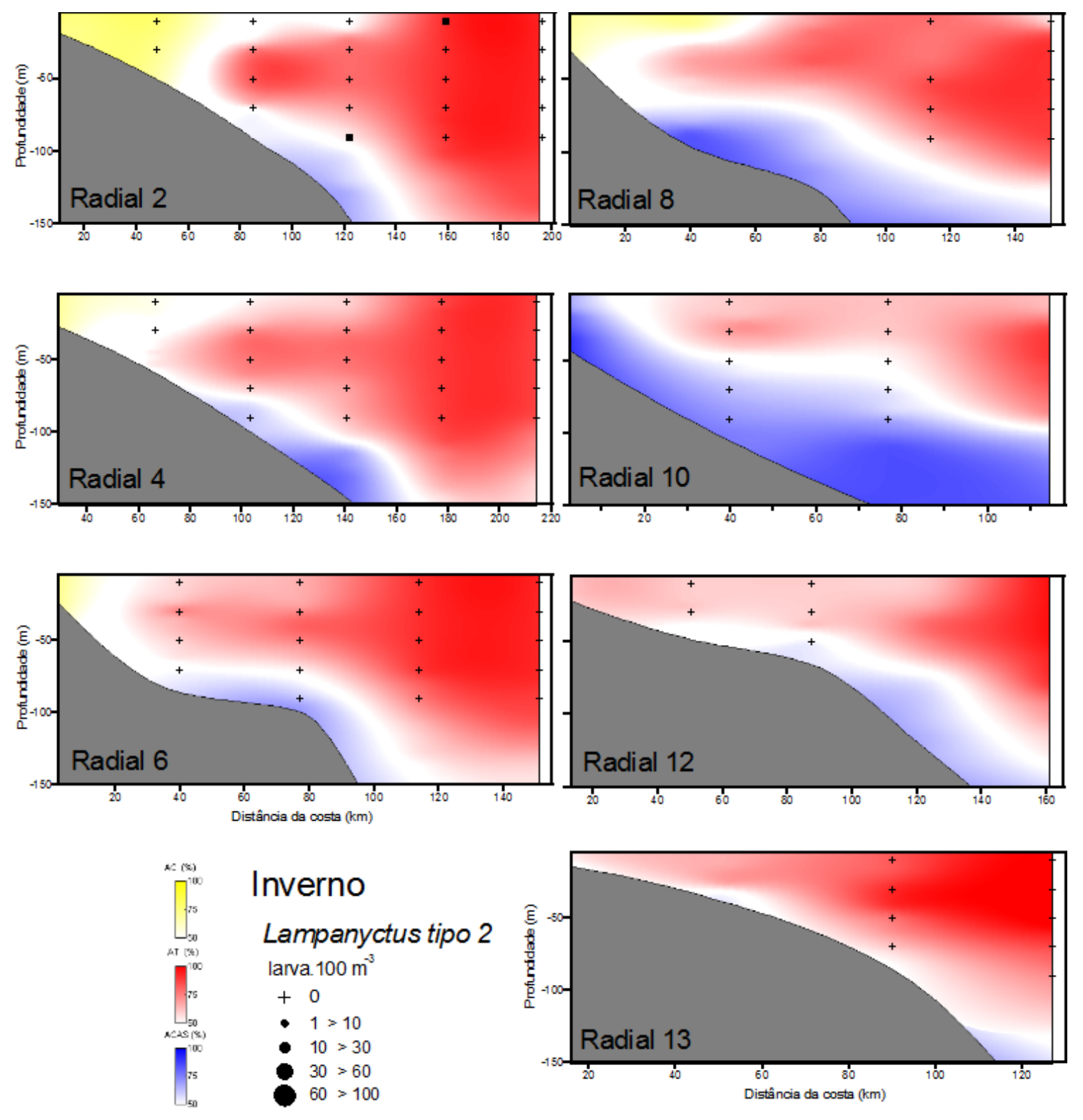

Figura 1.36: Distribuição vertical das larvas de Lampanyctus tipo 2 entre $0-100 \mathrm{~m}$ de profundidade em relação à distribuição das porcentagens de massa de água entre cabo de São Tomé e ilha de São Sebastião durante o inverno de 2002. 

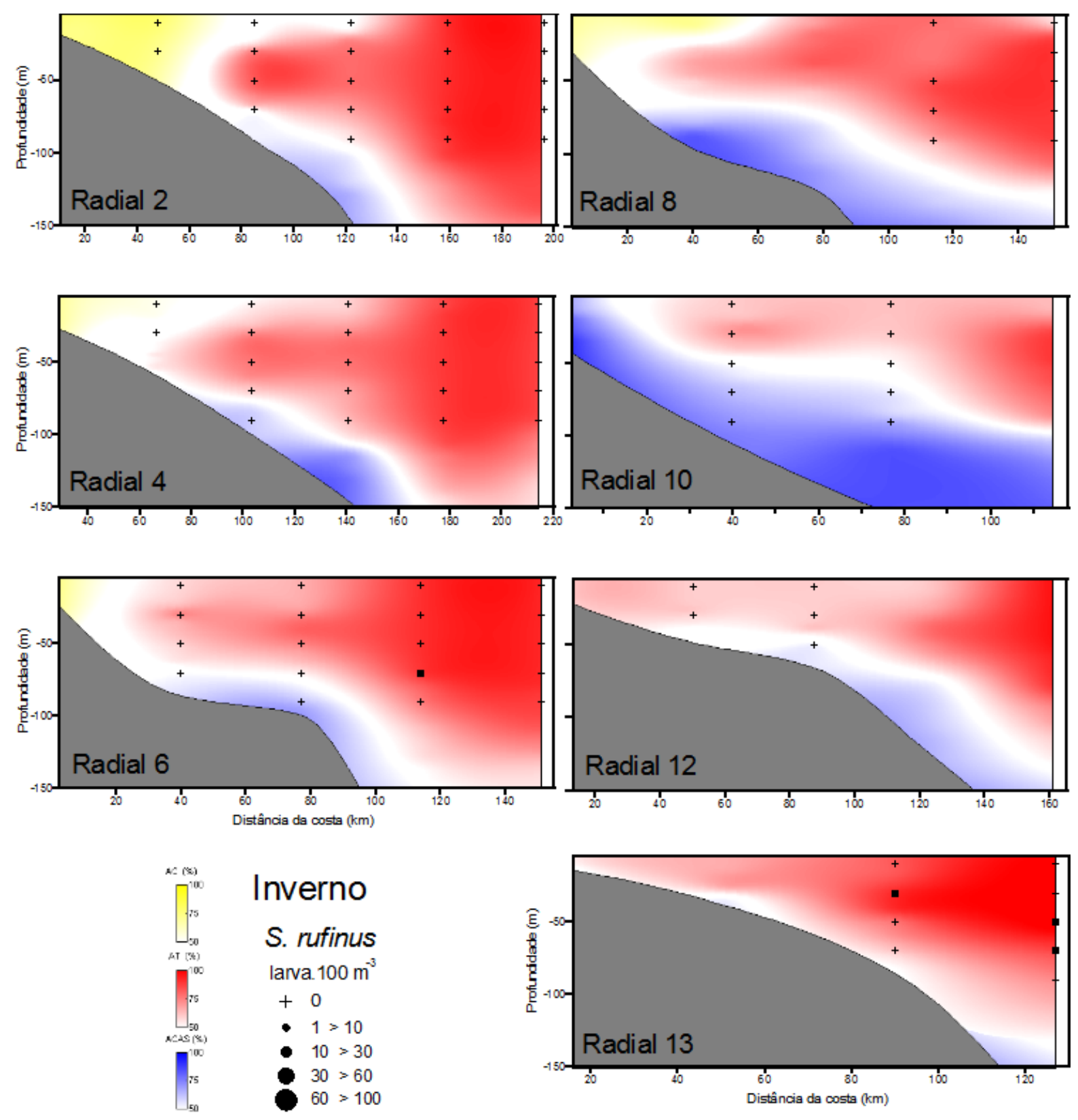

Figura 1.37: Distribuição vertical das larvas de Symbolophorus rufinus entre 0-100 m de profundidade em relação à distribuição das porcentagens de massa de água entre cabo de São Tomé e ilha de São Sebastião durante o inverno de 2002. 

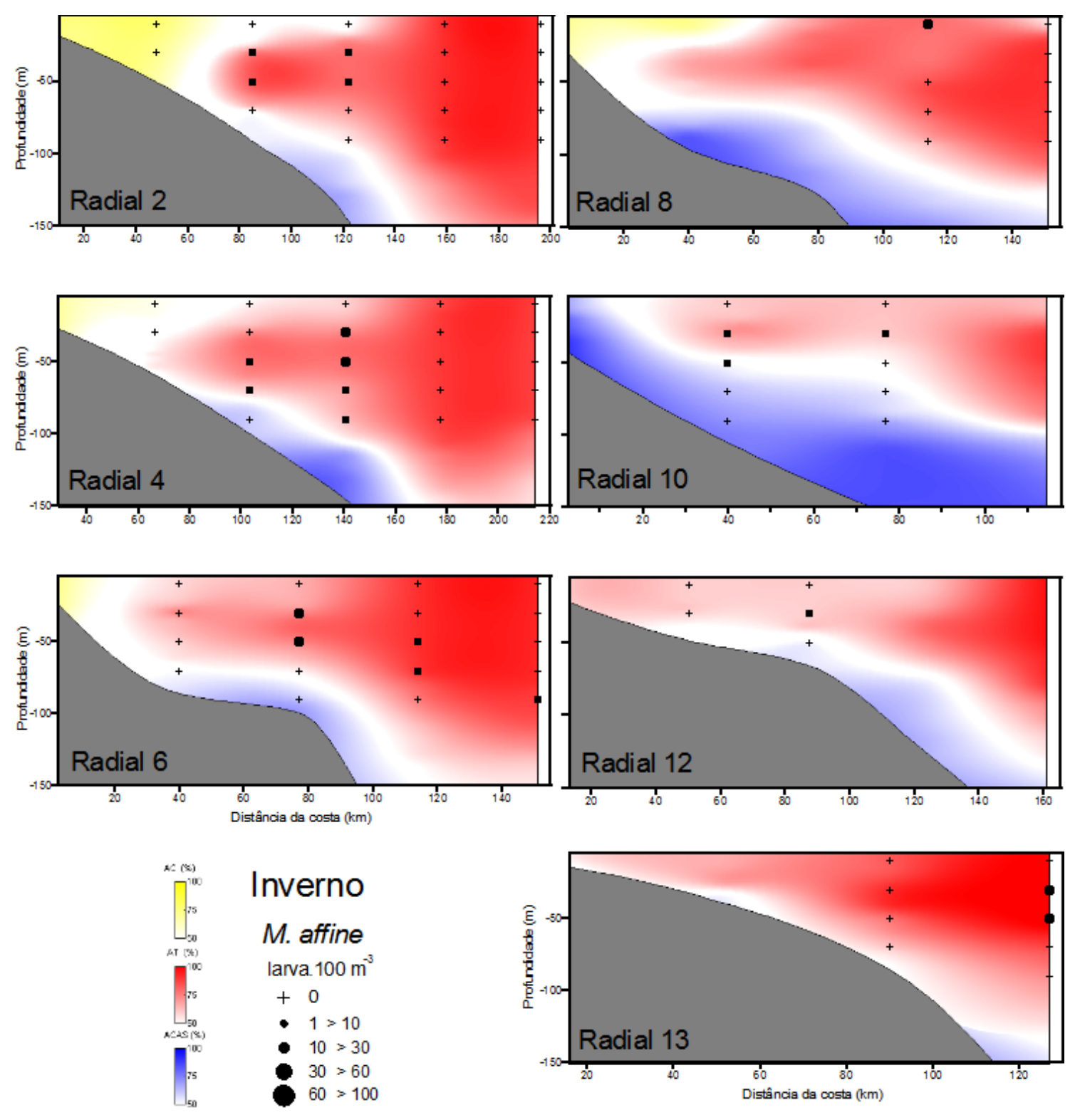

Figura 1.38: Distribuição vertical das larvas de Myctophum affine entre $0-100 \mathrm{~m}$ de profundidade em relação à distribuição das porcentagens de massa de água entre cabo de São Tomé e ilha de São Sebastião durante o inverno de 2002. 

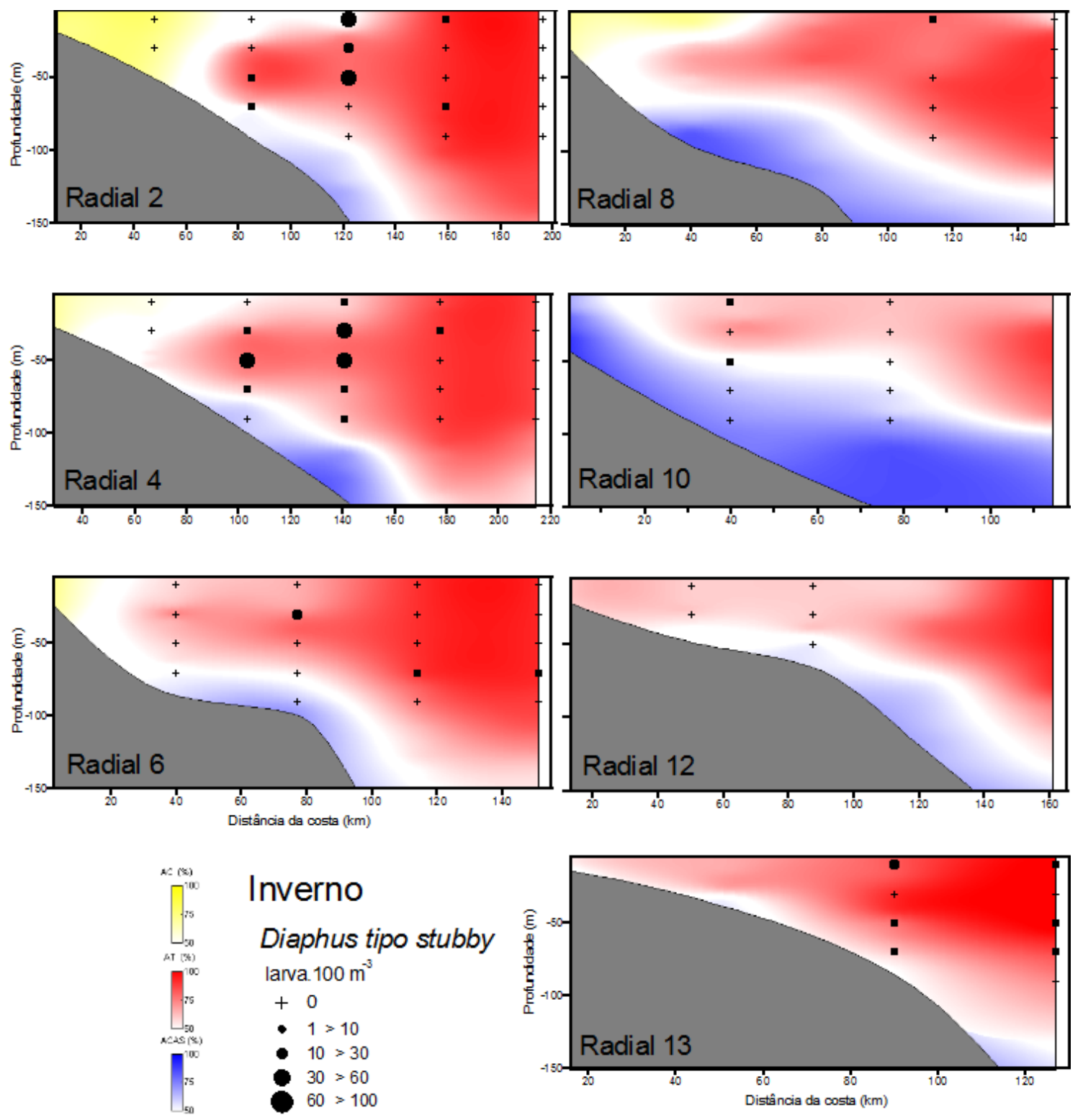

Figura 1.39: Distribuição vertical das larvas de Diaphus tipo stubby entre $0-100 \mathrm{~m}$ de profundidade em relação à distribuição das porcentagens de massa de água entre cabo de São Tomé e ilha de São Sebastião durante o inverno de 2002. 

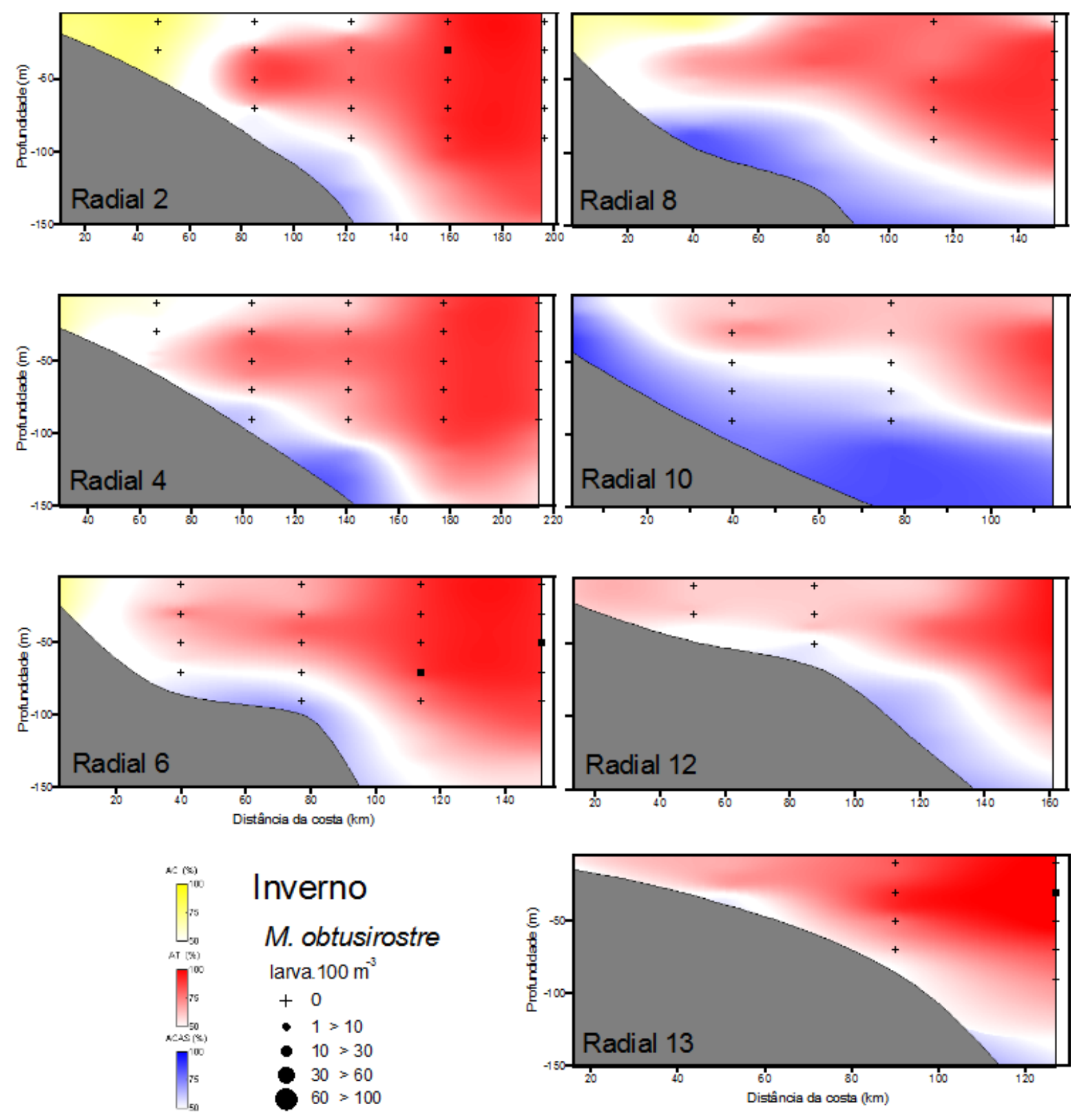

Figura 1.40: Distribuição vertical das larvas de Myctophum obtusirostre entre 0-100 m de profundidade em relação à distribuição das porcentagens de massa de água entre cabo de São Tomé e ilha de São Sebastião durante o inverno de 2002. 

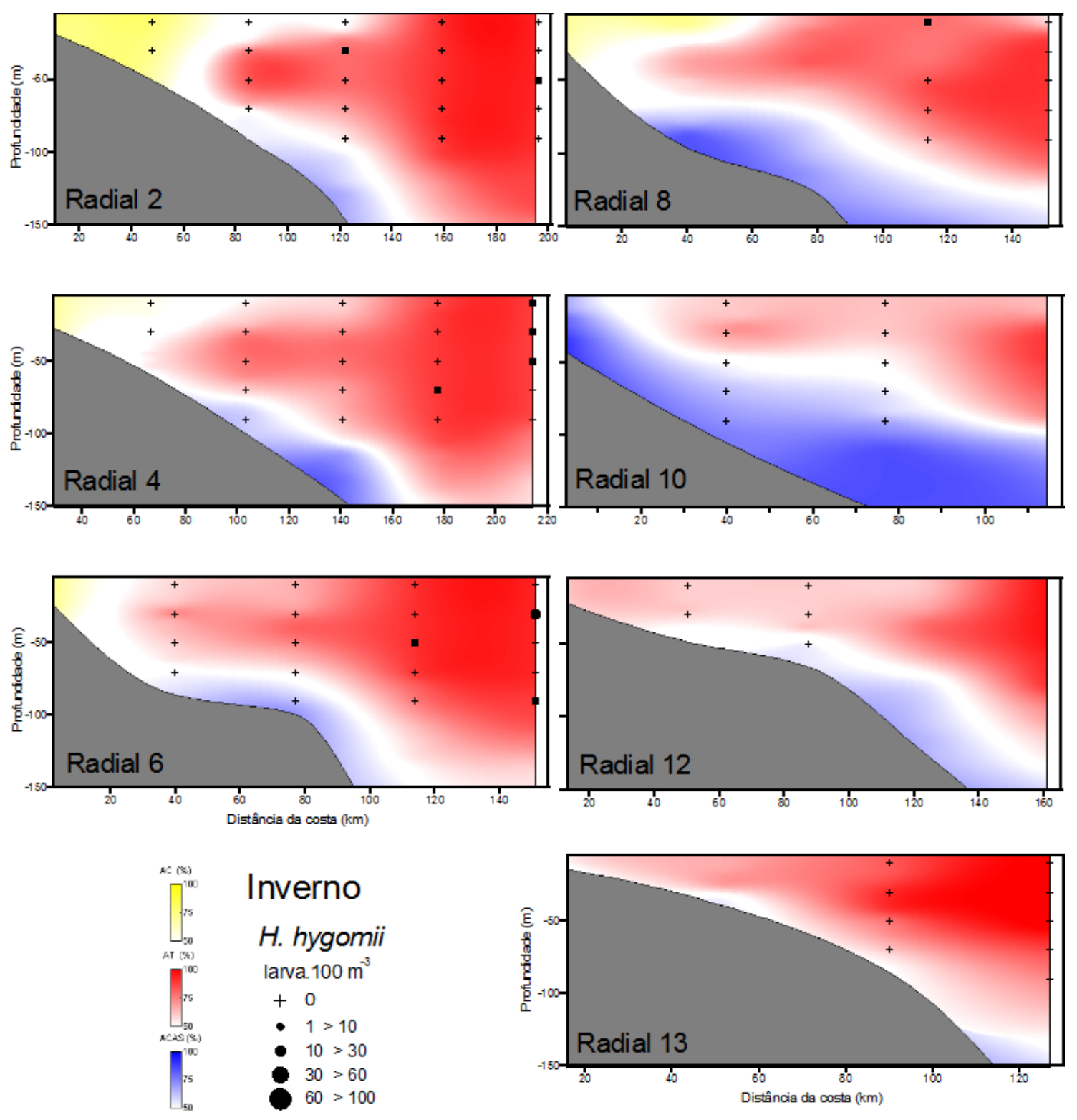

Figura 1.41: Distribuição vertical das larvas de Hygophum hygomii entre 0-100 m de profundidade em relação à distribuição das porcentagens de massa de água entre cabo de São Tomé e ilha de São Sebastião durante o inverno de 2002. 

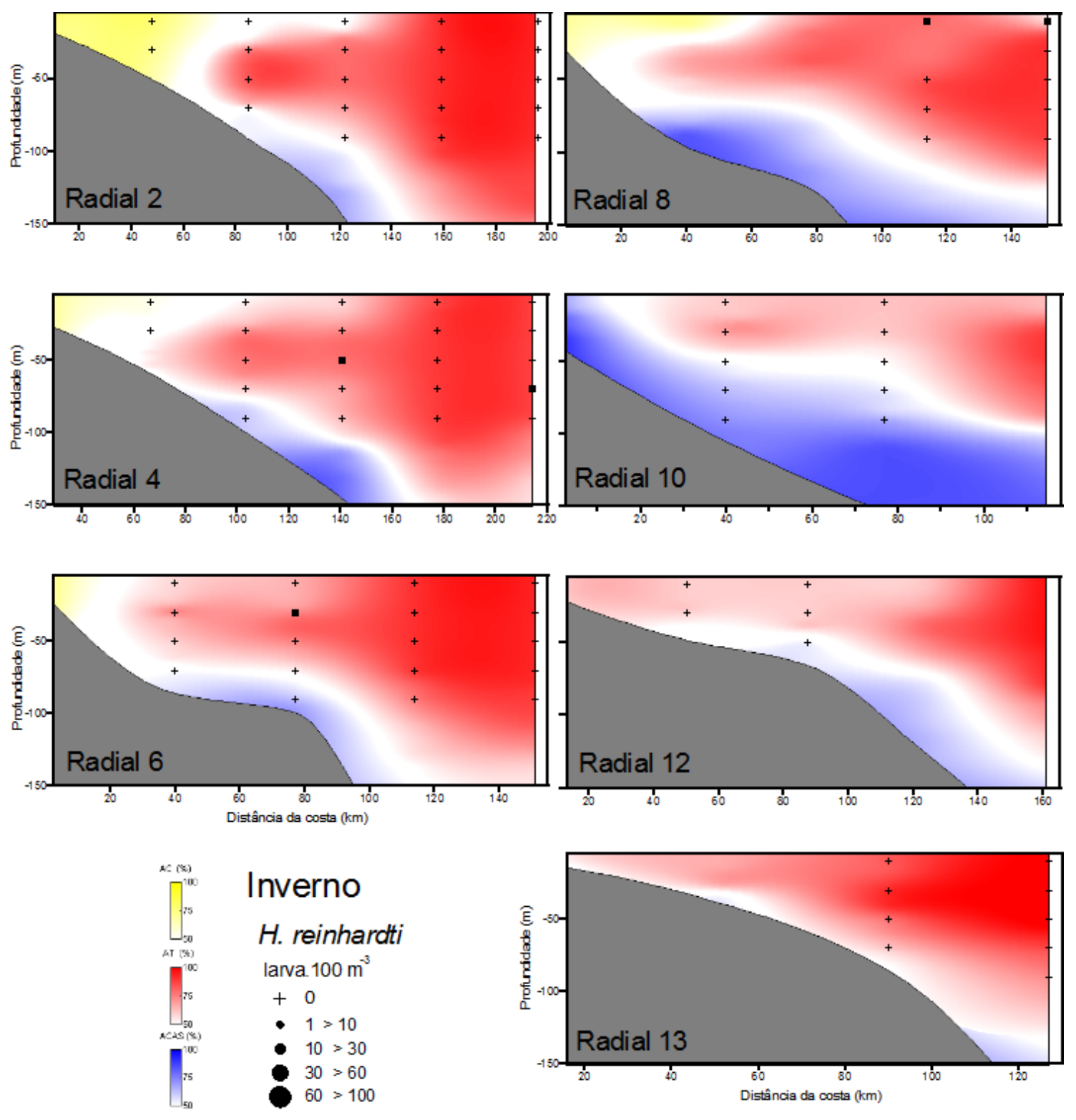

Figura 1.42: Distribuição vertical das larvas de Hygophum reinhardti entre 0-100 m de profundidade em relação à distribuição das porcentagens de massa de água entre cabo de São Tomé e ilha de São Sebastião durante o inverno de 2002. 

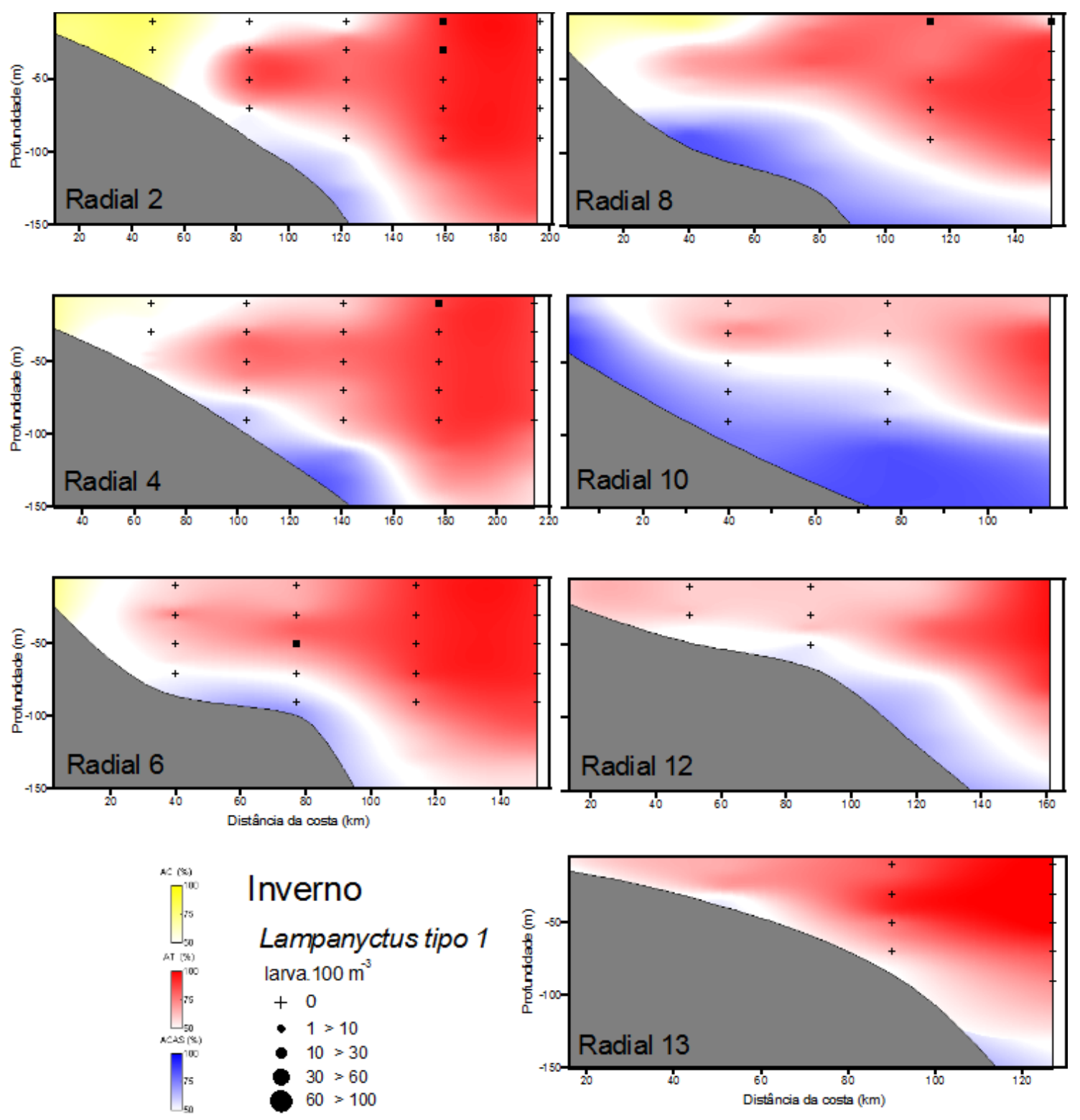

Figura 1.43: Distribuição vertical das larvas de Lampanyctus tipo 1 entre 0-100 m de profundidade em relação à distribuição das porcentagens de massa de água entre cabo de São Tomé e ilha de São Sebastião durante o inverno de 2002. 

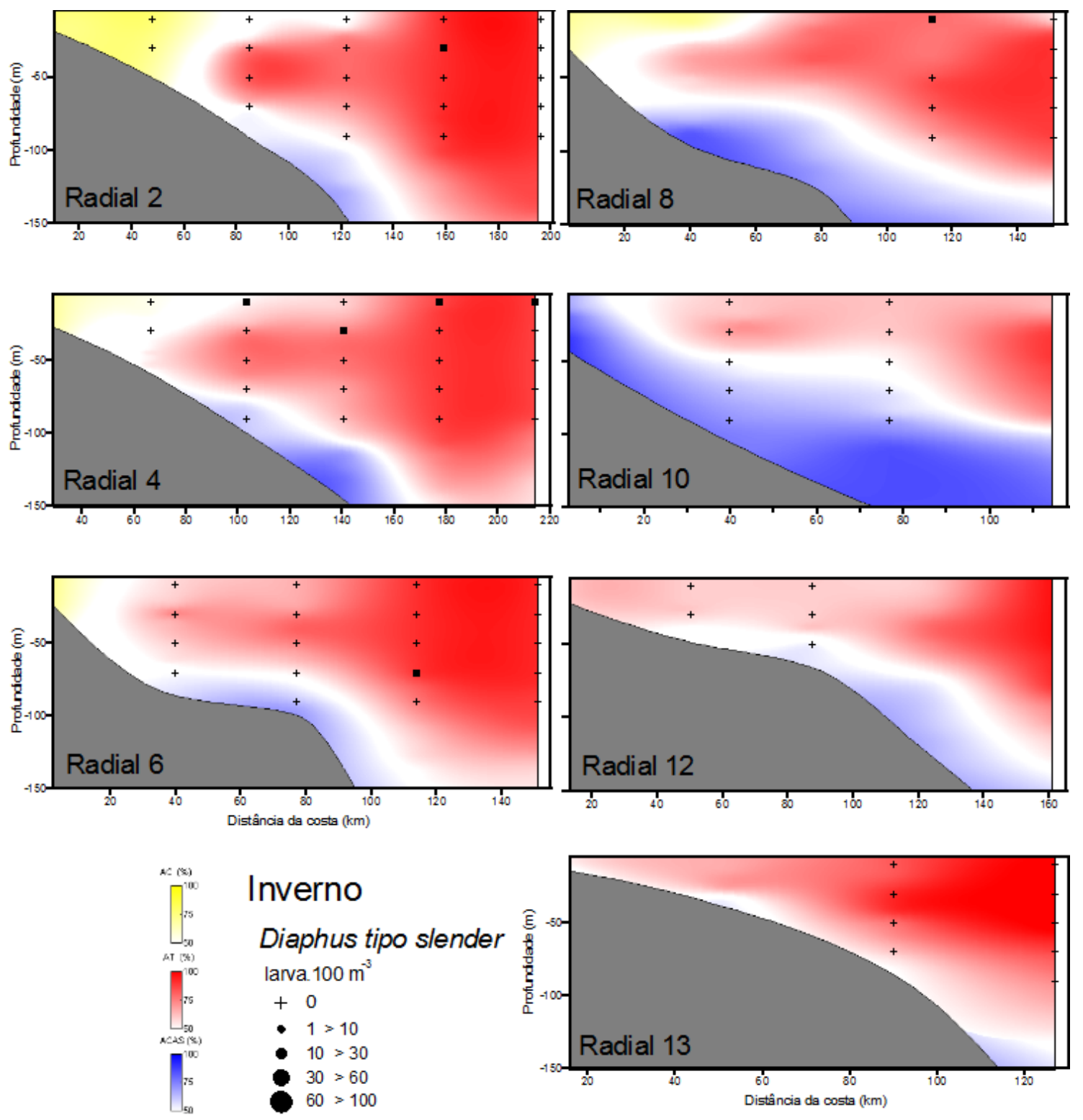

Figura 1.44: Distribuição vertical das larvas de Diaphus tipo slender entre 0-100 m de profundidade em relação à distribuição das porcentagens de massa de água entre cabo de São Tomé e ilha de São Sebastião durante o inverno de 2002. 

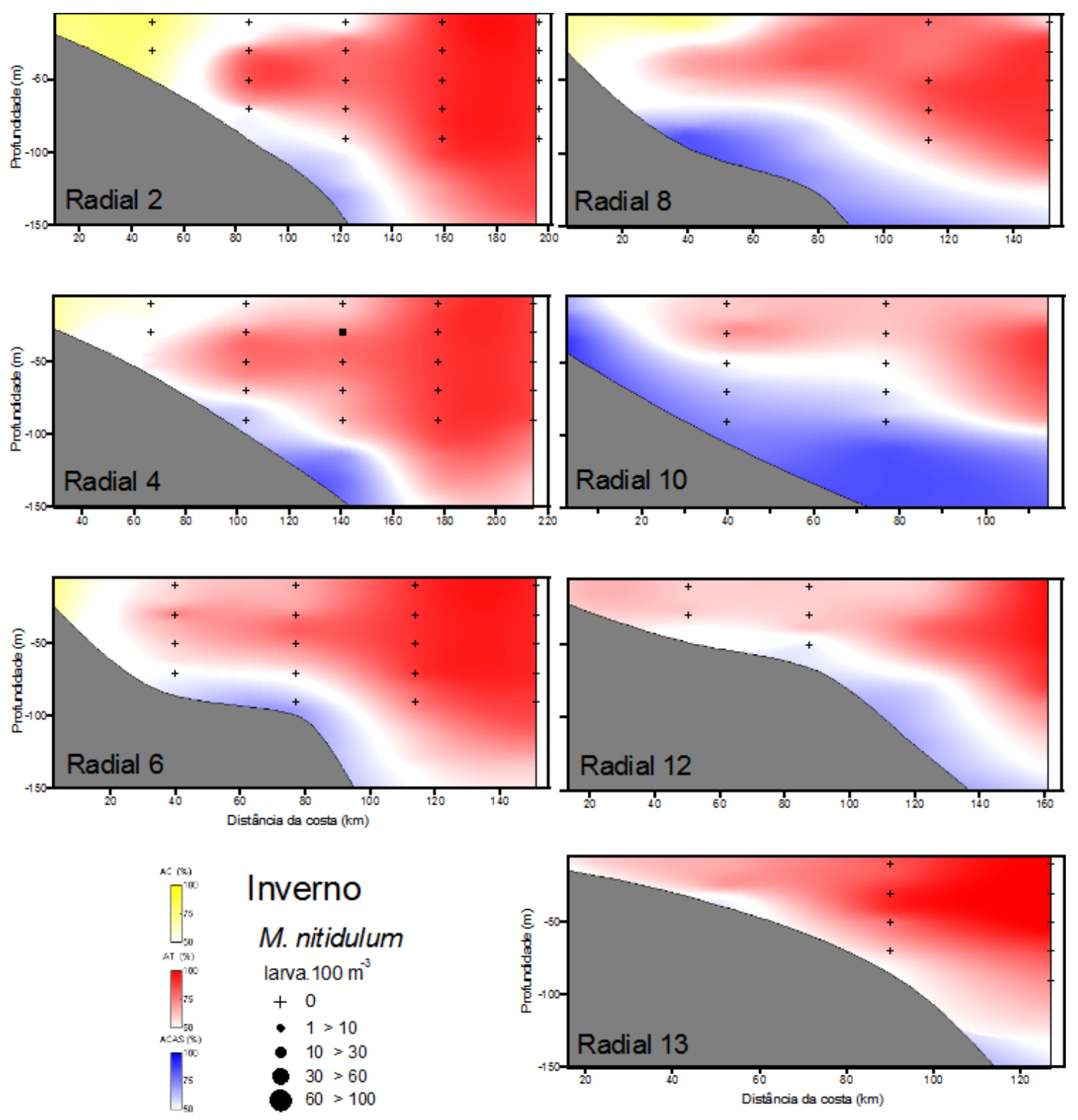

Figura 1.45: Distribuição vertical das larvas de Myctophum nitidulum entre 0-100 m de profundidade em relação à distribuição das porcentagens de massa de água entre cabo de São Tomé e ilha de São Sebastião durante o inverno de 2002. 

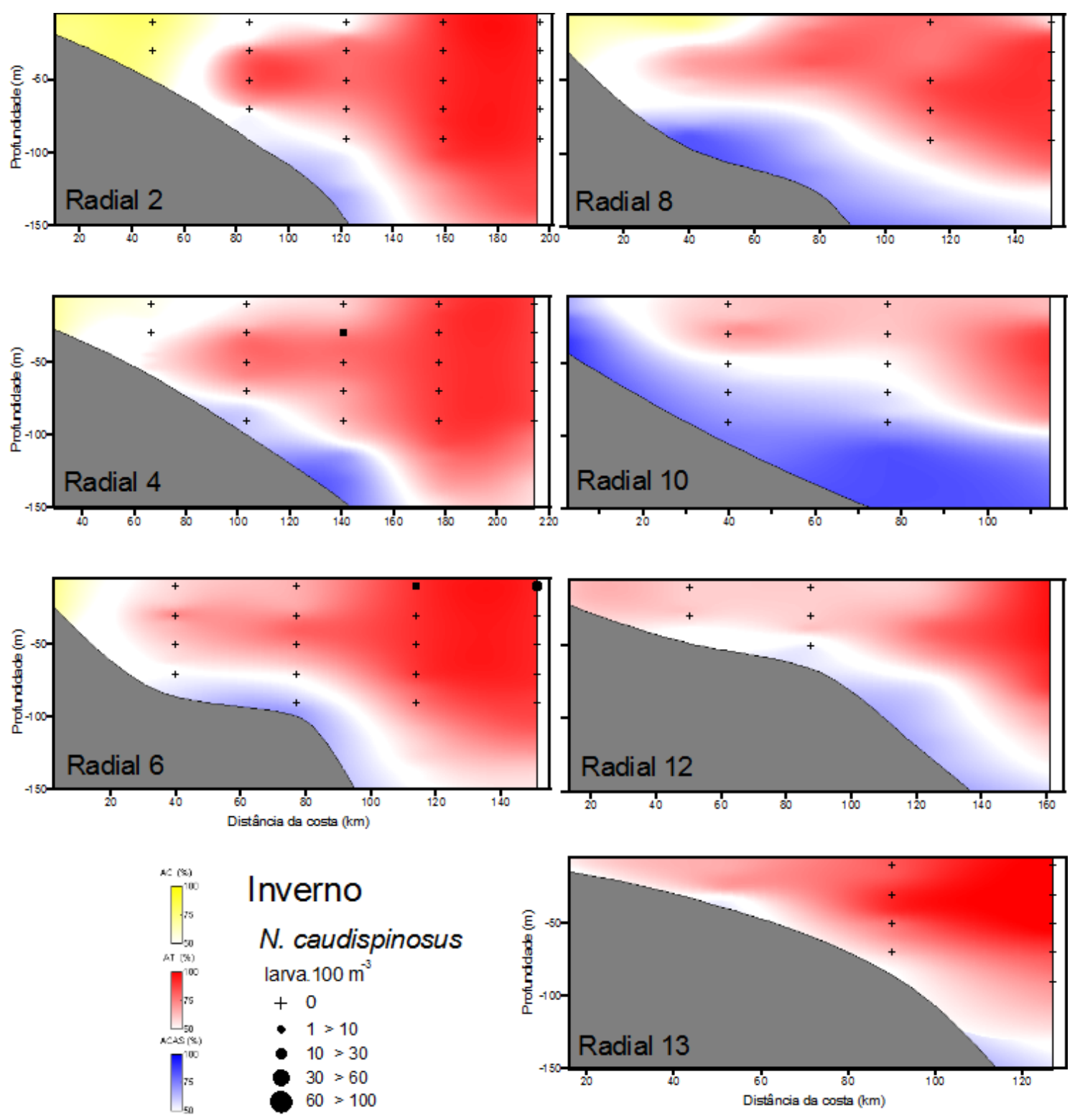

Figura 1.46: Distribuição vertical das larvas de Notoscopelus caudispinosus entre 0-100 m de profundidade em relação à distribuição das porcentagens de massa de água entre cabo de São Tomé e ilha de São Sebastião durante o inverno de 2002. 

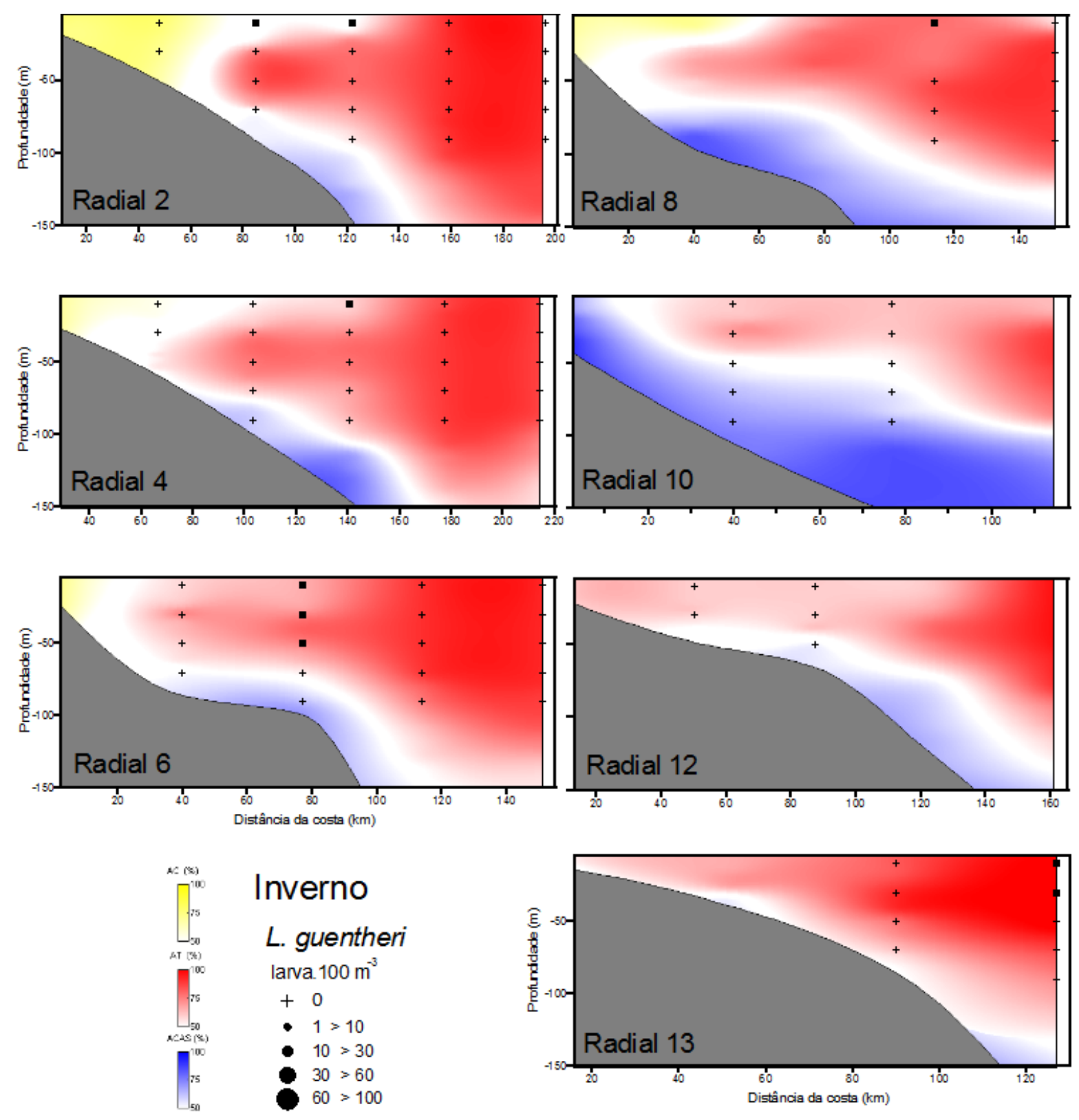

Figura 1.47: Distribuição vertical das larvas de Lepidophanes guentheri entre 0-100 m de profundidade em relação à distribuição das porcentagens de massa de água entre cabo de São Tomé e ilha de São Sebastião durante o inverno de 2002. 


\section{Capítulo 2}

\section{Crescimento e mortalidade das larvas de Myctophum affine}

\section{Introdução}

Myctophum affine é uma espécie oceânica, tropical e endêmica do Oceano Atlântico (Hulley, 1981), cuja ocorrência de indivíduos adultos em águas do sudeste brasileiro foi registrada além da isóbata de $600 \mathrm{~m}$ (Hulley, 1981; Santos, 2003). Essa espécie faz parte da dieta principal de predadores noturnos, como Thunnus atlanticus e Caranx crysos observados sobre a isóbata de $700 \mathrm{~m}$ (Zavalla-Camin et al., 1991). Na borda da plataforma, os mictofídeos em geral apresentam altos valores de biomassa, servindo de alimento para diversas espécies, como tubarões pelágicos e demersais, merluzas, atuns, entre outros (Gasalla et al., 2007).

As larvas de $M$. affine estão entre as mais abundantes nas amostras oceânicas de ictioplâncton ( Nonaka et al., 2000; Katsuragawa, 2007). Na costa brasileira são transportadas pelos meandros da Corrente do Brasil, atingindo a plataforma interna (Capítulo 1). Os trabalhos sobre os estágios iniciais do seu ciclo de vida relatam a variação sazonal da distribuição e abundância das larvas, e apenas um estudo, na altura de cabo Frio, relata o crescimento da fase larval dessa espécie (Bruscagin, 2003). Na costa brasileira, informações sobre crescimento e/ou mortalidade na fase larval existem para espécies comercialmente importantes ou com potencial de comercialização como corvina, sardinha, anchoita e chicharro, que ocorrem em áreas mais costeiras e de plataforma (Kitahara \& Matsuura, 1995; Katsuragawa \& Ekau, 2003; Albuquerque et al., 2009).

Estudos sobre o crescimento de larvas de Myctophidae foram realizados no Pacífico Norte ( Methot, 1981; Hayashi et al., 2001b; Moku et al., 2001, 2005; Takagi et al., 2006) e no Golfo do México (Conley \& Gartner, 2009), onde a estimativa da idade tem sido feita com base na leitura dos anéis de crescimento dos otólitos sagitta. Esses anéis de crescimento são estruturas formadas pela deposição alternada de carbonato de cálcio e proteína, normalmente em um 
período de 24 horas (Campana \& Neilson, 1985).

$\mathrm{Na}$ fase inicial de desenvolvimento, o crescimento rápido reduz a duração do período larval da espécie e, consequentemente, a exposição à predação, considerada uma das maiores causas da mortalidade (Houde, 2002). Por sua vez, variações na taxa de mortalidade podem contribuir para o sucesso ou falha do recrutamento, influenciando a abundância da população adulta (Houde, 2002).

Visando elevar o conhecimento sobre a autoecologia de $M$. affine, e considerando a importância da espécie para o ecossistema mesopelágico, neste estudo foram estimadas as taxas de crescimento e de mortalidade de suas das larvas, com a discussão dos possíveis fatores que poderiam afetá-las.

\section{Material e métodos}

Metodologia de campo

A descrição da área de estudo e a metodologia de coleta estão descritas na Introdução Geral e no Capítulo 1 da presente tese.

As larvas analisadas são provenientes das amostras coletadas com a rede bongô, malhagem de $505 \mu \mathrm{m}$. As amostras foram fixadas em álcool, conforme o seguinte procedimento: 1) retirava-se o máximo de organismos gelatinosos das amostras; 2) transferia-se o material para um recipiente de plástico contendo álcool $80 \%$, que era devidamente fechado e numerado; 3 ) duas trocas de álcool eram realizadas para cada amostra, ainda a bordo, após os períodos de 12 e de 24 horas, utilizando-se a mesma concentração; 4) finalmente as amostras eram estocadas em álcool 70\%, neutralizado com solução saturada de [Tris(hydroxymethyl) aminomethane]. 
Metodologia de laboratório

Identificação e obtenção das medidas

Em laboratório as amostras foram totalmente triadas sob estereomicroscópio binocular e as larvas de Myctophum affine foram identificadas segundo Moser \& Watson (2007). O comprimento padrão das larvas (distância da ponta do focinho ao final da notocorda ou osso hipural, dependendo da fase de desenvolvimento) foi obtido com o auxílio de uma régua micrométrica $(0,5 \mathrm{~mm}$ de precisão) acoplada à objetiva do estereomicroscópio. Apenas os indivíduos não danificados foram medidos para a análise de crescimento, totalizando 215 larvas. As larvas foram classificadas segundo seu estágio de desenvolvimento em préflexão, flexão, pós-flexão e transformação (Richards, 2006).

Retirada dos otólitos e preparação das lâminas

A metodologia para a retirada e montagem dos otólitos em lâmina de vidro e posterior análise em microscopia óptica foi a mesma utilizada por Secor et al. (1992) e Steven \& Campana (2011). Os otólitos sagitta de 115 indivíduos, obtidos durante o verão e o inverno, foram removidos com o auxílio de microestiletes, sob estereomicroscópio. Quando necessário os otólitos foram lavados em solução de hipoclorito de sódio para a retirada dos resíduos proteicos e enxaguados com água destilada em abundância. Os otólitos foram fixados nas lâminas com cola de cianoacrilato ${ }^{1}$, que garante a transparência e permite que os mesmos, se necessário, sejam lixados e polidos para melhor observação dos anéis próximos ao core. Nesse processo foram utilizadas lixas ${ }^{2}$ de $30 \mu \mathrm{m}$ e $3,0 \mu \mathrm{m}$.

\footnotetext{
${ }^{1}$ A cola utilizada foi a Super Bonder Precisão®. Também foram testadas as colas de cianoacrilato das marcas Super Bonder ${ }^{\circledR}$ e KrazyGlue ${ }^{\circledR}$, que vem na embalagem metálica convencional, mas embora não exista diferença na composição, esses produtos ficavam opacos em contato com a lâmina, não permitindo a visualização dos otólitos.

${ }^{2}$ Imperial Lapping Film (3M®)
} 
Leitura dos anéis de crescimento

Os anéis de crescimento de cada otólito foram contados três vezes sob microscópio óptico, pela mesma pessoa e com um intervalo de dias, para evitar qualquer viés. Foram consideradas as contagens que coincidiram pelo menos duas vezes, sendo descartadas aquelas cujo número de anéis diferiu nas três leituras realizadas.

A formação dos anéis de crescimento foi considerada diária, pois já foi validada para diversos teleósteos (Albuquerque et al., 2009; Soliman et al., 2009; Joh et al., 2011), incluindo os mictofídeos (Gartner, 1991a; Hayashi et al., 2001a, b; Moku et al., 2001, 2005).

\section{Análise de dados}

Curvas de crescimento

O crescimento das larvas de $M$. affine foi estimado a partir do modelo de Laird-Gompertz:

$$
\mathrm{L}_{\mathrm{t}}=\mathrm{L}_{0} \exp \mathrm{G}(1-\exp (-\mathrm{gt}))
$$

onde:

$\mathrm{L}_{\mathrm{t}}=$ comprimento larval na idade $\mathrm{t}$;

$\mathrm{L}_{0}=$ comprimento larval hipotético na idade zero (eclosão);

$\mathrm{G}$ = primeiro parâmetro de crescimento de Gompertz;

$g$ = segundo parâmetro de crescimento de Gompertz.

Os parâmetros dessa equação foram obtidos através do programa FISHPARM (Prager et al.,1989).

A equação sugerida por (Laird et al., 1965) se adapta ao crescimento de várias espécies nas fases iniciais de seu desenvolvimento. Esse modelo, proposto para uso em larvas de peixes por Kramer \& Zweifel (1970) e Zweifel \& Lasker (1976), tem sido utilizado para representar trajetórias de crescimento larval de diversos teleósteos (Campana \& Jones, 1992; Katsuragawa \& Ekau, 2003; Muhling et al., 2008b; Grote et al., 2012). 
O crescimento também foi estimado através das funções:

Exponencial:

$$
L_{t}=L_{0} \exp \cdot(g t)
$$

onde:

$\mathrm{L}_{\mathrm{t}}=$ comprimento larval na idade $\mathrm{t}$;

$\mathrm{L}_{0}=$ comprimento larval hipotético na idade zero (eclosão);

$g=$ coeficiente instantâneo de crescimento

$\mathrm{t}=$ idade estimada através da leitura dos anéis de crescimento dos otólitos.

e Linear:

$$
L_{t}=g \cdot t+L_{0},
$$

onde:

$\mathrm{L}_{\mathrm{t}}=$ comprimento larval na idade $\mathrm{t}$;

$\mathrm{L}_{0}=$ comprimento larval hipotético na idade zero (eclosão);

$\mathrm{g}=$ coeficiente instantâneo de crescimento

$\mathrm{t}=$ idade estimada através da leitura dos anéis de crescimento dos otólitos.

Essas funções são bastante utilizadas em estudos de crescimento de larvas de peixes (Campana \& Jones, 1992; Simms et al., 2008; Conley \& Gartner, 2009) e os resultados obtidos foram comparados com os do modelo de Laird-Gompertz.

A taxa de crescimento instantâneo foi estimada através da primeira derivada da equação de Laird-Gompertz:

$$
L^{\prime}=g \cdot G \cdot L_{0} \cdot \exp (G(1-\exp (-g \cdot t))-(g \cdot t)
$$

onde:

$L^{\prime}=$ taxa de crescimento instantâneo para cada dia t

$\mathrm{L}_{0}=$ comprimento larval hipotético na idade zero (eclosão);

$\mathrm{G}$ = primeiro parâmetro de crescimento de Gompertz;

$\mathrm{g}$ = segundo parâmetro de crescimento de Gompertz;

$\mathrm{t}=$ dias 


\section{Mortalidade}

Para que o coeficiente de mortalidade pudesse ser obtido, as larvas foram agrupadas em classes de comprimento de $1,00 \mathrm{~mm}$. Posteriormente, foi estimada a taxa diária de produção larval por unidade de área: $\mathrm{Pt} / \mathrm{dt}$, onde: $\mathrm{P}_{\mathrm{t}}=$ número de larvas em cada classe de comprimento dividida pelo número de estações positivas; $\mathrm{dt}=$ tempo necessário para que a larva atinja a próxima classe de comprimento. $A$ idade $t_{i}$ relativa a cada classe de comprimento foi estimada dividindo-se cada classe de comprimento pela taxa de crescimento média (mm/dia), obtida através da função linear (Hewitt \& Brewer, 1983; Katsuragawa \& Ekau, 2003).

A taxa de mortalidade instantânea foi estimada a partir do modelo loglinear $\ln \left(P_{t} / d_{t}\right)=\ln N_{0}-Z_{t}$, onde: $N_{0}=$ abundância inicial da classe de comprimento; Z (coeficiente instantâneo de mortalidade diária)= tangente do ângulo de inclinação da reta da regressão linear.

O coeficiente instantâneo de mortalidade foi convertido em taxa de sobrevivência (S) através do cálculo de $S=\exp (-Z)$. O valor complementar da taxa de sobrevivência (1-S) corresponde à taxa de mortalidade.

\section{Resultados}

Comprimento, idade e estágios de desenvolvimento

Foram coletadas 200 larvas de $M$. affine durante o verão e 41 no inverno, representando respectivamente $30 \%$ e $10 \%$, do total de larvas de Myctophidae coletadas em cada período. Sua frequência de ocorrência no verão foi de $47 \%$ e no inverno de $36 \%$.

O comprimento padrão das larvas de $M$. affine variou entre 2,75 e 4,50 mm nas larvas em pré-flexão, com maior frequência das larvas na classe de $3,00 \mathrm{~mm}$ $\mathrm{CP}$ (Figura 2.1). As larvas em flexão mediram entre 3,90 e $6,65 \mathrm{~mm} \mathrm{CP}$, com maior frequência da classe de 5,00 mm CP. As larvas em estágio de pós-flexão variaram entre 5,90 e 14,00 mm CP, com maior frequência da classe de 6,00 mm. A única larva em transformação media 14,00 mm CP. 
A contagem dos anéis diários, possível em 82 indivíduos, mostrou que a idade das larvas de $M$. affine variou entre 2 e 28 dias (Figura 2.2). A idade das larvas em estágio de pré-flexão $(n=27)$ variou entre 2 e 11 dias, em estágio de flexão $(n=23)$ entre 8 e 16 dias e em pós-flexão $(n=32)$, entre 11 e 28 dias.

\section{Modelos de crescimento}

O comprimento hipotético estimado para a larva no momento da eclosão foi de 2,57 mm CP pelo modelo de Laird-Gompertz, 2,67 mm CP pelo modelo exponencial e 1,65 mm CP pelo modelo linear (Figura 2.3). A idade estimada para as larvas em estágio de transformação $(14,00 \mathrm{~mm} \mathrm{CP})$ foi de aproximadamente 29 dias segundo os modelos de Laird-Gompertz e exponencial e 37 dias no modelo linear. O comprimento padrão das larvas nos modelos de Laird-Gompertz e exponencial sobrepuseram-se entre as idades de 2 e 15 dias, e a diferença nas idades mais avançadas foi menor do que $1,00 \mathrm{~mm}$ (Figura 2.3).

A taxa de crescimento, segundo o modelo de Laird-Gompertz, foi de 0,17 mm.dia ${ }^{-1}$, para as larvas com 2 dias de idade, e aumentou gradativamente, chegando a $0,73 \mathrm{~mm} \cdot \mathrm{dia}^{-1}$, nas larvas com 28 dias de idade, em estágio de transformação (Figura 2.4). A taxa média de crescimento estimada pela regressão linear foi de $0,33 \mathrm{~mm} \cdot \mathrm{dia}^{-1}(\mathrm{dp}=0,023 \mathrm{~mm})$. Esse valor foi igual ao estimado pelo modelo de Laird-Gompertz para as larvas entre 12 e 16 dias de idade (Figura 2.3), e próximo ao valor obtido através da regressão exponencial $\left(0,38 \mathrm{~mm} . \mathrm{dia}^{-1}\right)$, considerando que a transformação ocorra aos $14,00 \mathrm{~mm}$ CP.

\section{Mortalidade}

A mortalidade foi estimada apenas para o verão, pois no inverno o número de larvas coletadas e otólitos analisados foram considerados insuficientes para a obtenção de resultados confiáveis. Dessa forma, para o cálculo da mortalidade, foi utilizada a taxa de crescimento média obtida apenas com os dados do verão, que foi igual a $0,2986 \mathrm{~mm} / \mathrm{dia}$.

A extrusão da rede foi detectada para as larvas menores do que $3,00 \mathrm{~mm}$ CP (Figura 2.1). Assim, as larvas da classe de 2,00 mm CP não foram utilizadas 
no cálculo da taxa de mortalidade diária.

A partir da relação entre o logaritmo das taxas de produção larval por unidade de área ( $\ln (\mathrm{Pt} / \mathrm{dt}))$ e idade (Figura 2.5), foi obtida a seguinte equação:

$$
\ln (P t / d t)=-0,1252 \cdot t+0,6091\left(R^{2}=0,9745\right)
$$

Assim, o coeficiente de mortalidade diária instantânea (Z), que é a tangente do ângulo de inclinação da reta, foi estimado em 0,1252 . Como a sobrevivência ( $S$ ) é igual a $\operatorname{Exp}(-Z)$, temos que $S=0,882$, isto é, $88,2 \%$, indicando uma taxa de mortalidade diária de $11,8 \%$ durante o período do verão.

\section{Discussão}

\section{Crescimento}

Os modelos de Laird-Gompertz e o exponencial foram considerados representativos do crescimento das larvas de $M$. affine. O modelo exponencial foi o que melhor se ajustou aos dados, porém o valor de $L_{0}$ estimado pelo modelo de Laird-Gompertz $(2,57 \mathrm{~mm} \mathrm{CP})$ foi mais próximo ao encontrado na literatura $(>2,5$ mm CP) (Moser \& Watson, 2006). Porém, Bruscagin (2003) obteve um $L_{0}$ pouco menor, no valor de 2,23 $\mathrm{mm}$, para as larvas de $M$. affine coletadas entre a costa e a isóbata de $2.000 \mathrm{~m}$ em frente a cabo Frio. Em cinco espécies de Myctophidae, analisadas no Golfo do México, o modelo exponencial foi o que melhor representou 0 crescimento das larvas, enquanto 0 modelo linear também subestimou o $L_{0}$, assim como no presente estudo, indicando que elas deveriam medir menos de 2,0 mm CP no momento da eclosão (Conley \& Gartner, 2009). As larvas de $M$. affine estão entre as espécies de Myctophidae que possuem o menor comprimento padrão no momento da eclosão, mas o comprimento no qual atingem a fase de transformação é similar ao apresentado por outras espécies (Tabela 2.1).

A taxa de crescimento inicial das larvas de $M$. affine é baixa e aumenta com a idade. A aceleração do crescimento ao longo do tempo até o estágio de 
transformação também é característica de diversas espécies, tanto de Myctophidae (Methot, 1981; Conley \& Gartner, 2009) como de outras famílias (Kohno et al., 1988; Ekau, 1998; Katsuragawa \& Ekau, 2003; Albuquerque et al., 2009; Hurst et al., 2009). Em relação a espécies de outras famílias do Atlântico sudoeste, a taxa de crescimento inicial de $M$. affine $\left(0,17 \mathrm{~mm}\right.$.dia $\left.{ }^{-1}\right)$ foi menor do que a do carangídeo Trachurus lathami $\left(>0,30 \mathrm{~mm} \cdot \mathrm{dia}^{-1}\right)$ (Katsuragawa \& Ekau, 2003) e de Engraulis anchoita (0,70 mm.dia $\left.{ }^{-1}\right)$ com 10 dias de idade (Ekau, 1998). Porém continuou aumentando até a idade de 28 dias $\left(0,76 \mathrm{~mm} \cdot\right.$ dia $\left.^{-1}\right)$, superando a taxa de crescimento de $T$. lathami, cujo crescimento máximo foi de $0,5 \mathrm{~mm}$ dia. $^{-1}$ (Katsuragawa \& Ekau, 2003), e aproximando-se de E. anchoita, cuja taxa máxima é de $0,9 \mathrm{~mm} \cdot \mathrm{dia}^{-1}$, aos 27 dias de idade (Ekau, 1998). Devido ao número insuficiente de larvas em estágio de transformação e à ausência de juvenis, não foi possível detectar o momento de estabilização do crescimento de $M$. affine.

Uma das razões para o crescimento inicial mais lento, observado dentro da amplitude de CP amostrado, é provavelmente a mudança de alimentação endógena para exógena (Kohno et al., 1988; Katsuragawa \& Ekau, 2003; Martell et al., 2005; Butler et al., 2012). Nesse período, as taxas metabólicas aumentam e há uma redução na energia disponível para o crescimento (Yúfera \& Darias, 2007; Hurst et al., 2009), pois parte dessa energia é gasta na procura e captura de presas (Hunt von Herbing et al., 2001) e na formação de diversos órgãos e estruturas, como espinhos e nadadeiras (Itagaki, 2005). Conforme a larva cresce, seu sucesso na captura e a qualidade energética das presas aumentam, permitindo que a taxa de crescimento seja elevada (Hunt von Herbing et al., 2001).

A taxa de crescimento média, obtida através da regressão linear, das larvas de $M$. affine pode ser considerada intermediária entre os mictofídeos (Tabela 2.1). Conley \& Gartner (2009) sugerem que as diferentes taxas de crescimento devem refletir a morfologia das espécies. Segundo os autores, aquelas com os maiores CP no estágio adulto, como as do gênero Ceratoscopelus, que atingem 70 mm CP (Gartner Jr., 1993), crescem mais rápido do que aquelas de tamanho diminuto, como Notolychnus valdiviae, que atinge 22 mm CP (Gartner Jr., 1993). 
O período larval de $M$. affine é um dos menores de sua família (Tabela 2.1), principalmente quando comparado aos das espécies de clima subártico, como Stenobrachius leucopsaurus e Diaphus theta, que estendem-se por aproximadamente 70 dias (Moku et al., 2001; Nishimura et al., 1999). A temperatura afeta a taxa de crescimento, o desenvolvimento e, consequentemente, a duração do período larval (Martell et al., 2005; Houde, 2009; Satoh et al., 2012). O aumento na temperatura eleva as taxas das reações metabólicas, portanto as larvas de espécies que ocorrem em águas quentes crescem e se desenvolvem mais rapidamente do que aquelas que ocorrem em águas frias (Houde \& Zastrow, 1993). A análise da distribuição vertical mostrou que as larvas de $M$. affine estão associadas à AT, que é considerara uma massa de água quente, caracterizada por temperaturas superiores a $20^{\circ} \mathrm{C}$ (Capítulo 1).

Além da temperatura, a alimentação é um dos principais fatores que contribuem para a variabilidade na taxa de desenvolvimento na fase exógena (Kamler, 1992), embora seja difícil separar a influência da temperatura sobre a alimentação das larvas no ambiente, pois quanto maior a temperatura, maior deve ser a quantidade de alimento consumida para suprir sua demanda metabólica (Kamler, 1992). Na área do presente estudo, a maioria das larvas de M. affine apresentou boa condição nutricional, indicando haver alimento suficiente, embora várias estivessem em condição intermediária e algumas exibissem sinais de inanição (Capítulo 4). Essa variação na condição nutricional explicaria porque indivíduos com a mesma idade apresentam diferentes estágios de desenvolvimento e CP variados. As larvas em boas condições nutricionais devem se desenvolver e crescer mais rapidamente do que aquelas que não encontram alimento em quantidade e com a qualidade necessárias. No presente estudo, não foi possível associar diretamente a condição nutricional das larvas com a taxa de crescimento. No entanto, Grote et al. (2012) não conseguiram observar uma forte relação entre a condição nutricional e a taxa de crescimento das larvas de Merluccius paradoxus e $M$. capensis, sugerindo uma complexa relação entre esses fatores. 


\section{Mortalidade}

A taxa de mortalidade diária para as larvas de peixes marinhos normalmente excede $10 \%$ e seu valor médio é de $21 \%$ (Houde \& Zastrow, 1993). A taxa de mortalidade diária de $11,8 \%$ estimada para $M$. affine no presente trabalho é, portanto, compatível com o descrito para espécies de outras famílias, pois não existem informações para larvas dessa espécie ou de qualquer outro mictofídeo na literatura. Comparado com as espécies epipelágicas de pequeno porte da costa brasileira, observamos que essa taxa é ligeiramente superior à de Engraulis anchoita (10\%) (Kitahara \& Matsuura, 1995) e inferior à de Trachurus lathami (17\%) (Katsuragawa \& Ekau, 2003). A taxa de mortalidade pode variar anualmente, como mostra a comparação dos dados obtidos por (Matsuura, 1983) e (Kurtz, 1999) para Sardinella brasiliensis, mas pode ser menor do que a variação sazonal (Rooker et al., 1999).

Diversos fatores, físicos (temperatura, turbulência, retenção, dispersão) e biológicos (doenças, parasitas, disponibilidade de presas, predação), influenciam as taxas de mortalidade das larvas de peixes no ambiente, mas, devido à interação desses fatores, é praticamente impossível quantificar a influência de cada um deles. Por exemplo, presume-se que a mortalidade das larvas seja reduzida quando os adultos desovam em locais onde a circulação é favorável ao transporte das mesmas para as áreas de berçário (Harden-Jones, 1968). Essa desova deve ocorrer também em sincronização com a produção de zooplâncton nessas áreas, para que o alimento esteja disponível quando a larva passar a se alimentar de maneira exógena (Cushing, 1975). Esses fatores podem ter contribuído para a baixa taxa de mortalidade observada no presente trabalho. Visto que os adultos de $M$. affine tem sua ocorrência registrada a partir da isóbata de $600 \mathrm{~m}$ (Santos, 2003), a maior abundância de suas larvas entre as isóbatas de 100 e 200 m indica que estas devem ser transportadas pela Corrente do Brasil desde a área oceânica, mais oligotrófica (McClain et al., 2004; Morel et al., 2010), até a plataforma externa, onde a produtividade é relativamente mais elevada. Somado a isso, a maior abundância de larvas durante o verão indica que a desova de $M$. affine deve ser mais intensa nesse período quando ocorre um pico de 
produção zooplânctonica na área de estudo (Lopes, 2006; Goçalo, 2008).

A inanição e a predação são consideradas as maiores causas da mortalidade das larvas de peixe (Houde, 2002). No entanto é difícil avaliar a mortalidade por inanição no ambiente, pois os indivíduos em más condições nutricionais crescem e se desenvolvem mais lentamente, aumentando seu tempo de exposição à mortalidade por predação (Grote et al., 2012; Satoh et al., 2012). Essa por sua vez, parece atuar seletivamente sobre os menores indivíduos, que podem estar ou não em inanição (Houde, 2002). A suscetibilidade das larvas diminui com o crescimento, pois os indivíduos mais desenvolvidos aumentam sua capacidade de escapar do predador (Bailey \& Houde, 1989). Detectar os predadores e quantificar a predação no ambiente também é uma tarefa árdua, porque as larvas são facilmente digeridas e, portanto, são de difícil identificação quando encontradas no conteúdo estomacal de seu predador.

A dificuldade em avaliar as causas da mortalidade não torna menos importante quantificá-la. Os adultos de Myctophidae em geral, incluindo M. affine, fazem parte da dieta de diversos organismos, incluindo peixes de importância comercial (Zavalla-Camin et al., 1991; Hopkins et al., 1996; Muto et al., 2005; Collins et al., 2008). Os mesopelágicos também podem substituir as espécies que compõe a dieta principal de outros predadores, quando essas populações desaparecem ou diminuem devido, por exemplo, a mudanças ambientais (FloresCoto et al., 2008). Em anos de El Niño na corrente de Humboldt, foi constatado que Merluccius gayi peruanus aumenta o consumo de pequenos pelágicos, como Myctophidae e Bregmacerotidae, devido ao declínio da anchova, sua presa principal (Tam et al., 2006). Isso significa que a presença dos mesopelágicos impede que haja um efeito bottom-up sobre as populações de predadores nessas circunstâncias (Tam et al., 2006). Desse modo, podemos considerar que uma falha no recrutamento desses mesopelágicos pode afetar negativamente a disponibilidade de alimento para seus predadores.

A avaliação das taxas de mortalidade ao longo do tempo pode gerar comparações que permitam compreender quais valores estão dentro do esperado e predizer se haverá sucesso ou falha no recrutamento das espécies. A existência 
de grande variação nas taxas de mortalidade e a comparação entre taxas de vários anos ou diferentes períodos do mesmo ano tornam as estimativas mais confiáveis (Houde, 2002). Não foi possível fazer uma comparação entre anos, porque este é o primeiro estudo sobre a mortalidade de larvas de $M$. affine, e nem entre os diferentes períodos, devido ao número de larvas coletadas no inverno, que representou $20 \%$ do valor observado no verão. Nota-se que ao longo da costa brasileira a abundância de larvas de $M$. affine diminui consideravelmente durante os períodos de outono e inverno (Nonaka et al., 2000; Katsuragawa, 2007; Castro et al., 2010). Assim, a taxa de mortalidade observada no verão pode ser um bom indicativo do recrutamento da população dessa espécie, pois as larvas que eclodem durante o inverno devem representar uma pequena parcela da população adulta. 
Tabela 2.1: Comparação das taxas de crescimento diária, comprimento padrão no momento da eclosão (E) e no início da transformação (T) e duração do período larval das larvas de Myctophidae analisadas em diversas localidades. CP= comprimento padrão, $\mathrm{n}=$ número de indivíduos amostrados, $\mathrm{T}^{\circ} \mathrm{C}=$ variação da temperatura na área de coleta, ou nas estações positivas, durante o período de estudo, local= local de coleta.

\begin{tabular}{|c|c|c|c|c|c|c|c|c|c|}
\hline \multirow{2}{*}{ Espécie } & \multirow{2}{*}{ Equação de crescimento } & \multirow{2}{*}{$\begin{array}{c}\text { Taxa de } \\
\text { crescimento } \\
(\mathrm{mm} / \mathrm{dia}) \\
\end{array}$} & \multicolumn{2}{|r|}{$\mathrm{CP}(\mathrm{mm})$} & \multirow{2}{*}{$\begin{array}{c}\text { Período } \\
\text { larval (dias) }\end{array}$} & \multirow{2}{*}{$\mathrm{n}$} & \multirow{2}{*}{$\mathrm{T}^{\circ} \mathrm{C}$} & \multirow{2}{*}{ Local } & \multirow{2}{*}{ Referência } \\
\hline & & & $\mathrm{E}$ & $\mathrm{T}$ & & & & & \\
\hline Myctophum affine & $L_{t}=2,56 \exp 20,40(1-\exp (-0,003009 t))$ & $0,17-0,73$ & 2,57 & 14 & 29 & 82 & $30-20$ & SE Brasil & Presente estudo \\
\hline Myctophum affine & $L_{t}=2,6704 \exp 0,0561 t$ & 0,3 & 2,67 & 14 & 29 & 82 & $30-20$ & SE Brasil & Presente estudo \\
\hline Myctophum affine & $L_{t}=0,3262 t+1,6598$ & 0,35 & 1,65 & 14 & 37 & 82 & $30-20$ & SE Brasil & Presente estudo \\
\hline Myctophum affine & $\mathrm{L}_{\mathrm{t}}=2,23 \cdot \exp 23,24(1-\exp (-0,00344 \mathrm{t}))$ & $0,22-0,79$ & 2,23 & & & 84 & $28-16$ & SE Brasil & (Bruscagin, 2003) \\
\hline Benthosema suborbital & $L=2,5 \exp 0,03 t$ & 0,2 & 2,5 & $10-11$ & 48 & 65 & $30-21$ & Golfo do México & (Conley \& Gartner, 2009) \\
\hline Ceratoscopelus townsendi & $L=3,1 \exp 0,05 t$ & 0,4 & 3,1 & $14-15$ & 31 & 32 & $30-22$ & Golfo do México & (Conley \& Gartner, 2009) \\
\hline Hygophum taaningi & $L=4,2 \exp 0,02 t$ & 0,2 & 4,2 & $11-12$ & 50 & 28 & $30-23$ & Golfo do México & (Conley \& Gartner, 2009) \\
\hline Myctophum selenops & $L=2,8 \exp 0,04 t$ & 0,2 & 2,8 & $9-10$ & 31 & 22 & $30-24$ & Golfo do México & (Conley \& Gartner, 2009) \\
\hline Notolychnus valdiviae & $L=3,0 \exp 0,02 t$ & 0,1 & 3 & $9-11$ & 60 & 29 & $30-25$ & Golfo do México & (Conley\&Gartner, 2009) \\
\hline Diaphus theta & $\mathrm{L}=2,65+0,141 \mathrm{t}$ & 0,14 & 2,65 & $12,7(11-14)$ & $71(59-80)$ & 13 & & Pacifico Noroeste & (Moku et al., 2001) \\
\hline $\begin{array}{l}\text { Stenobrachius } \\
\text { leucopsarus }\end{array}$ & $L=84,96-79,32 \exp (-0,34 t)$ & $0,11-0,28$ & 4,5 & & & 141 & & Pacifico Nordeste & (Methot, 1981) \\
\hline Ceratoscopelus warmingii & & 0,35 & & & $20-35$ & 25 & & Corrente de Kuroshio & (Takagi et al., 2006) \\
\hline $\begin{array}{l}\text { Stenobrachius } \\
\text { leucopsarus }\end{array}$ & $L_{t}=106,2(1-\exp -0,265(t-0,432))$ & 0,26 & & & 70 & 181 & & Mar de Bering & (Nishimura et al., 1999) \\
\hline $\begin{array}{l}\text { Diaphus dumerilli } \\
\text { (metamorfose) }\end{array}$ & $\mathrm{L}=74,86(1-\exp -0,005(\mathrm{t}-(-1,82)))$ & 0,35 & & & 28 & 189 & & Golfo do México & (Gartner, 1991b) \\
\hline $\begin{array}{l}\text { Lepidophanes guentheri } \\
\text { (metamorfose) }\end{array}$ & $\mathrm{L}=72,83(1-\exp -0,005(\mathrm{t}-5,0))$ & 0,29 & & & 27 & 280 & & Golfo do México & (Gartner, 1991b) \\
\hline $\begin{array}{l}\text { Benthosema suborbitale } \\
\text { (metamorfose) }\end{array}$ & $\mathrm{L}=32,83(1-\exp -0,010(\mathrm{t}-19,3))$ & 0,2 & & & 40 & 178 & & Golfo do México & (Gartner, 1991b) \\
\hline $\begin{array}{l}\text { Myctophum asperum } \\
\text { (depois da metamorfose) }\end{array}$ & $S L=85,0 \exp (-1,886 \exp (-0,010 t))$ & 0,24 & & & & 48 & & Pacífico Noroeste & (Hayashi et al., 2001b) \\
\hline
\end{tabular}




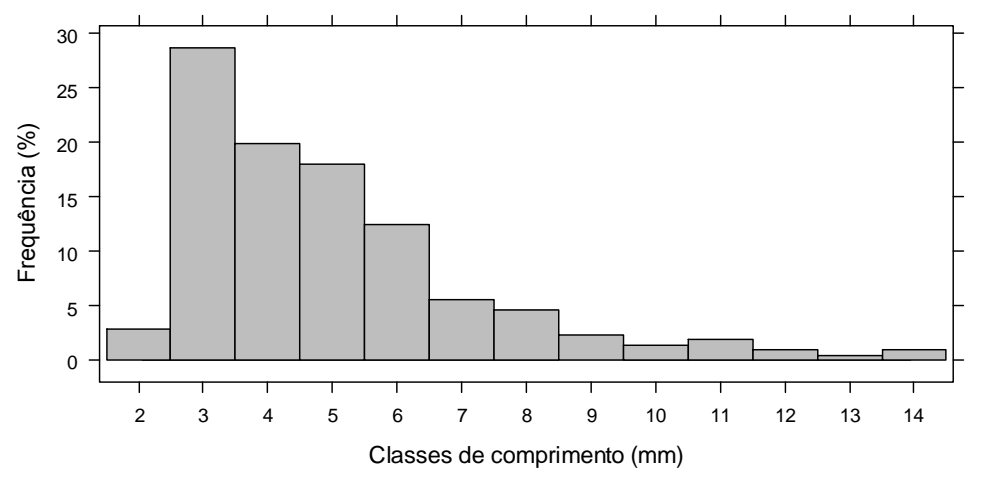

Figura 2.1: Distribuição de frequência (\%) das classes de comprimento padrão $(\mathrm{mm})$ das larvas de Myctophum affine, durante o verão $(n=178)$ e o inverno $(n=38)$ de 2002, entre cabo de São Tomé e ilha São Sebastião.

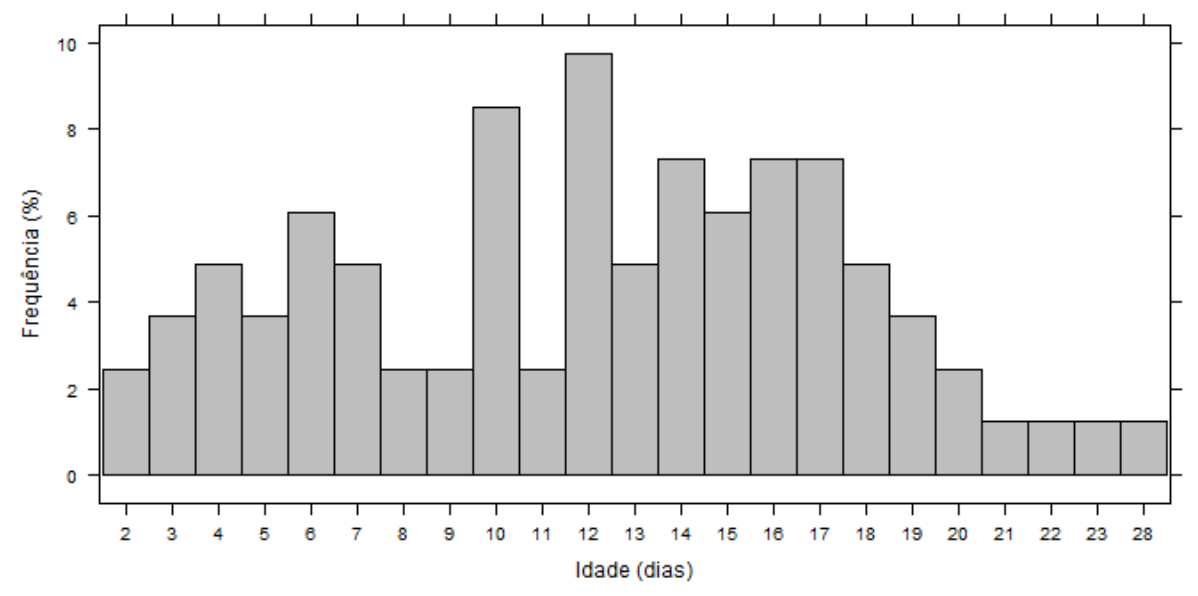

Figura 2.2: Distribuição de frequência (\%) da idade (dias), estimada a partir da contagem dos anéis de crescimento dos otólitos sagitta, das larvas de Myctophum affine, no verão $(n=74)$ e inverno $(n=10)$ de 2002, entre cabo de São Tomé e São Sebastião. 


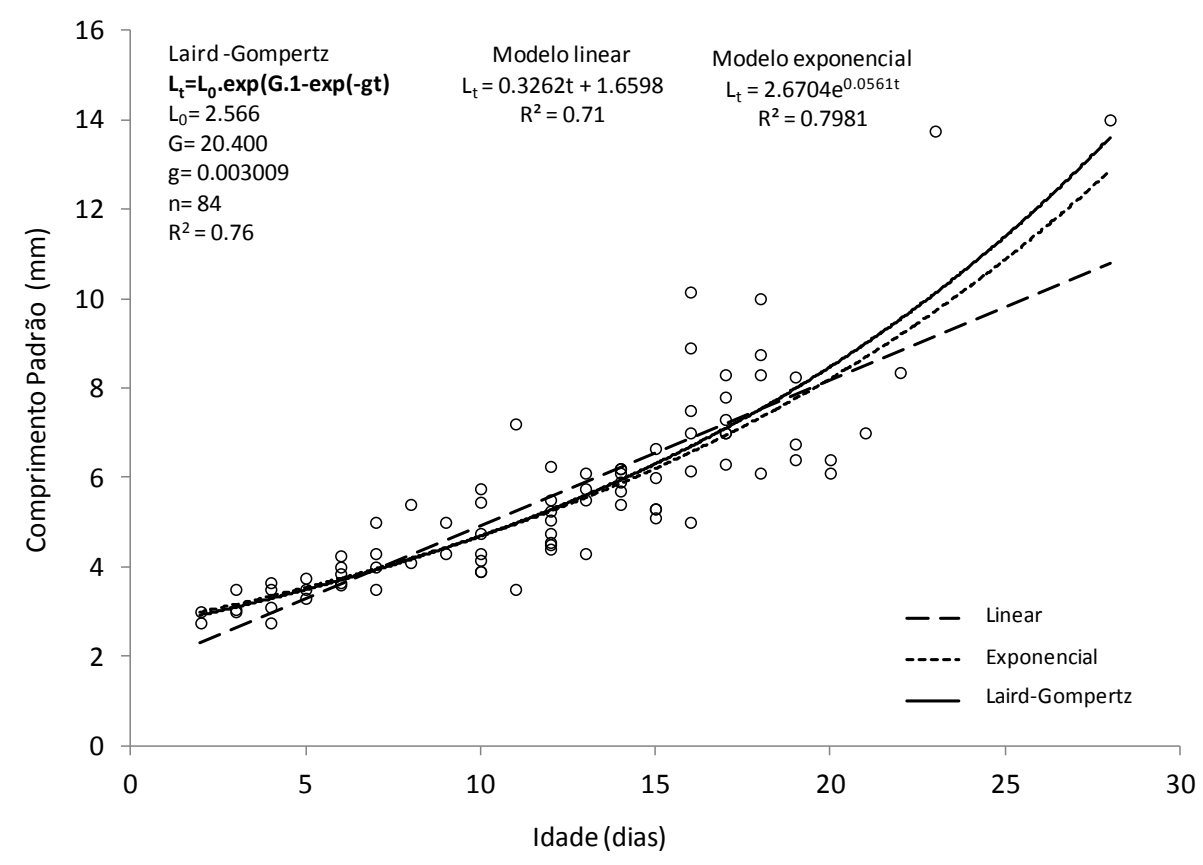

Figura 2.3: Curvas de crescimento das larvas de Myctophum affine estimadas através dos modelos de Laird-Gompertz, exponencial e linear. A idade foi estimada através da contagem dos anéis de crescimento dos otólitos sagitta durante o verão e o inverno de 2002, entre cabo de São Tomé e ilha de São Sebastião.

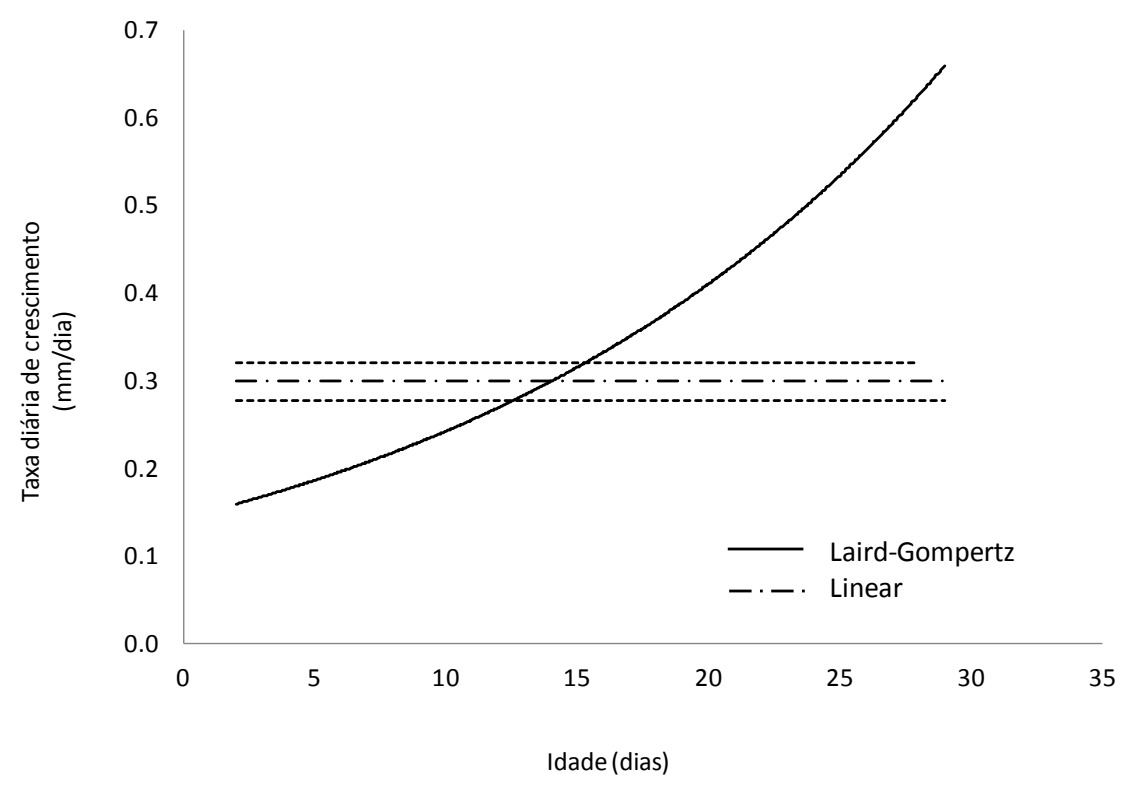

Figura 2.4: Taxa diária de crescimento das larvas de Myctophum affine, estimada através da regressão linear e da derivada do modelo de Laird-Gompertz, Os dados de idade dos modelos foram estimados através da contagem dos anéis de crescimento dos otólitos sagitta, durante o verão e o inverno de 2002 entre cabo de São Tomé e São Sebastião. 


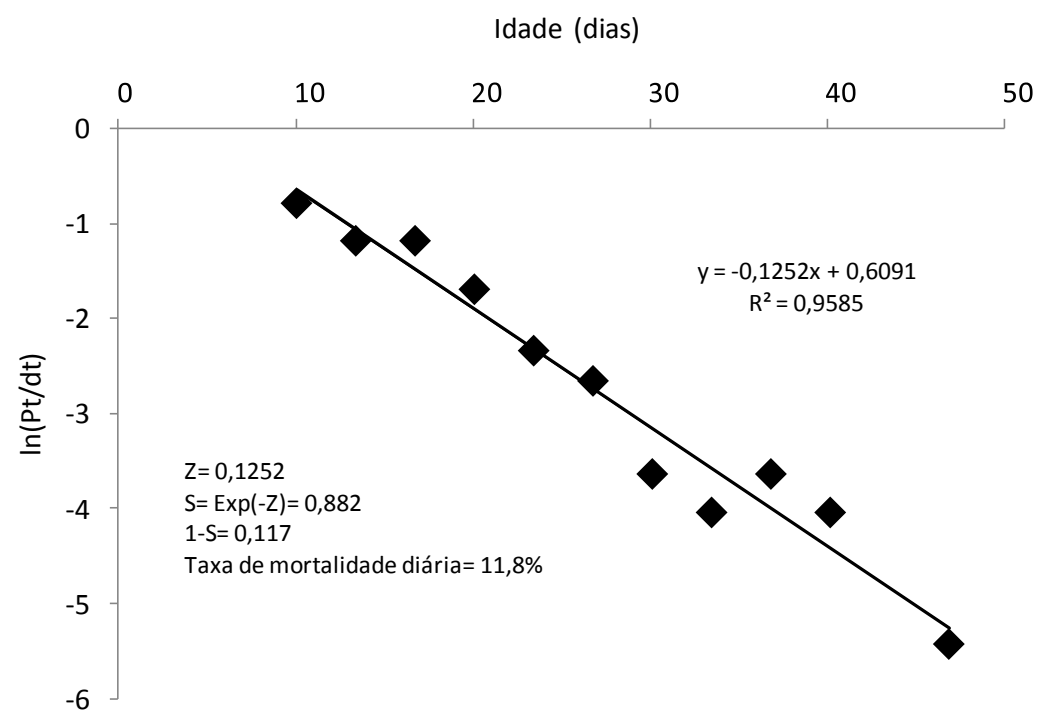

Figura 2.5: Coeficiente de mortalidade instantânea ( $Z$ ) das larvas de Myctophum affine, $\mathrm{P}_{\mathrm{t}}=$ taxa de produção; $\mathrm{t}_{\mathrm{i}}$ idade (dias) estimada através da transformação das classes de comprimento em duas utilizando-se a taxa de crescimento do modelo linear do verão, $\mathrm{d}_{\mathrm{t}}=$ tempo entre $t_{i}$ e $t_{i+1}$, da leitura dos anéis de crescimento dos otólitos sagitta, 


\section{Capítulo 3}

\section{Condição nutricional das larvas de Myctophum affine baseada na análise histológica dos hepatócitos}

\section{Introdução}

Os mictofídeos, conhecidos como peixes-lanterna, devido à presença de fotóforos distribuídos pelo corpo, ocorrem em todos os oceanos e são especialmente abundantes nas áreas oceânicas tropicais e subtropicais (Nelson, 2006). Esses peixes possuem um importante papel na teia trófica oceânica: compõem a dieta de peixes (Zavala-Camin et al., 1991; Muto et al., 2005), lulas, aves e mamíferos (Hopkins et al., 1996; Ohizumi et al., 2003; Collins et al., 2008) e são um dos principais consumidores de crustáceos zooplanctônicos (Hopkins et al., 1996).

Diversos estudos têm demonstrado que as larvas de Myctophidae também são importantes predadoras do zooplâncton, pois apresentam alta incidência desses organismos no trato digestório (Conley \& Hopkins, 2004; Sassa \& Kawaguchi, 2004; Sassa \& Kawaguchi, 2005; Bernal et al., 2013). Suas espécies são seletivas em relação ao tipo e ao tamanho da presa, que podem variar também de acordo com o estágio de desenvolvimento (Conley \& Hopkins 2004). Estudos sobre a alimentação das larvas são importantes para conhecer seus hábitos alimentares e a relação trófica entre as espécies (Bernal et al., 2013), mas são limitados em mostrar a verdadeira condição nutricional das larvas, devido ao ciclo diário de alimentação (Ferron \& Leggett, 1994). Ou seja, a presença a ou ausência de presas no trato digestório depende do horário da coleta.

A condição nutricional pode ser estudada através de medidas morfométricas, proporção entre RNA:DNA ou através de índices histológicos, que consiste no estabelecimento de um sistema de classificação baseado na análise de células e órgãos. (Ferron \& Leggett, 1994; Catalán, 2003). A principal vantagem dos índices histológicos é que eles são independentes do tamanho e da 
idade do indivíduo para inúmeras espécies (Catalán, 2003). As larvas em inanição normalmente exibem degenerações nos tecidos, especialmente do trato digestório e glândulas associadas, como fígado e pâncreas. O fígado é um dos órgãos que responde mais rapidamente a privação de alimento. Seus vacúolos estocam glicogênio e lipídio, que são as primeiras substâncias a serem mobilizadas em caso de inanição (O'Connell \& Paloma 1981; Margulies 1993; Chen et al., 2007). A análise e a classificação histológica dos hepatócitos nas larvas de peixes apresenta características comuns a diversas espécies (Sieg, 1992a; Margulies, 1993; Sieg, 1998; Catalán, 2003; Chen et al., 2007; Diaz et al., 2011a) e portanto pode ser considerada um bom parâmetro para avaliar a sua condição nutricional. O’Connel \& Paloma (1981), utilizando uma técnica para corar o glicogênio, associaram o seu nível nos hepatócitos à condição nutricional das larvas de Engraulis mordax em seus primeiros estágios de desenvolvimento. Posteriormente, Sieg (1992a; 1998) utilizou os níveis de glicogênio, em conjunto com outras observações, diretamente na classificação histológica dos hepatócitos de E. anchoita e Vincinguerria spp.

Não há relatos sobre a condição nutricional dos mictofídeos. Entre as larvas de peixes mesopelágicos, apenas as do gênero Vincinguerria (Phosichthyidae) tiveram sua condição analisada, apresentando pior condição nutricional na plataforma em relação àquelas da região oceânica (Sieg, 1992a). Em águas brasileiras as larvas de Myctophum affine são uma das mais abundantes (Nonaka et al., 2000; Castro et al., 2010; Bonecker et al., 2012; e Capítulo 1 da presente tese) e estão amplamente distribuídas sobre a plataforma continental intermediária e externa, com ocorrência esparsa na plataforma interna (Nonaka et al., 2000, e Capítulo 1 da presente tese), embora a ocorrência dos adultos tenha sido registrada somente além da isóbata de $600 \mathrm{~m}$ (Santos, 2003). As larvas de Phosichthyidae também chegam a ocupar a plataforma interna, provavelmente aproveitando a maior abundância de presas presente nessa região (Goçalo et al., 2011). Esses autores sugerem que uma avaliação da condição nutricional dessas larvas poderia confirmar essa hipótese.

Considerando a abundância, a ampla distribuição e a importância 
ecológica das larvas de $M$. affine na costa sudeste do Brasil, o objetivo deste estudo foi analisar a sua condição nutricional, através de análises histológicas dos hepatócitos, sob a hipótese de que existe diferença na sua condição nutricional entre áreas com diferentes características oceanográficas. Além disso, os níveis de glicogênio nos hepatócitos também foram analisados e comparados com a classificação histológica utilizada.

\section{Material e métodos}

\section{Metodologia de campo}

A descrição da área de estudo e a metodologia de coleta estão descritos no Capítulo 1.

As amostras da rede $500 \mu \mathrm{m}$ foram fixadas em álcool logo após a coleta, de acordo com o seguinte procedimento: 1) o maior número possível de organismos gelatinosos foi retirado das amostras; 2) o material coletado foi transferido para um recipiente plástico contendo álcool $80 \%$, devidamente fechado e numerado; 3) duas trocas de álcool foram realizadas para cada amostra, ainda a bordo, após os períodos de 12 e de 24 horas, utilizando-se a mesma concentração; 4) finalmente as amostras foram estocadas em álcool $70 \%$,

neutralizado com ${ }^{\odot}$ Sigma 7-9 (Tris[hydroxymethyl] aminomethane). A fixação e preservação das larvas em álcool garante a preservação do glicogênio presentes nas células do fígado.

\section{Metodologia de laboratório}

Identificação, obtenção de medidas e estimativa da idade

Em laboratório o material coletado foi totalmente triado sob estereomicroscópio binocular e as larvas de Myctophum affine foram identificadas segundo Moser \& Watson (2007). O comprimento padrão das larvas (distância da ponta do focinho ao final da notocorda ou osso hipural, dependendo da fase de 
desenvolvimento) foi obtido com o auxílio de uma régua micrométrica acoplada à objetiva do estereomicroscópio. As larvas foram classificadas segundo seu estágio de desenvolvimento em pré-flexão, flexão, pós-flexão e transformação (Richards, 2006). A idade das larvas foi obtida através da leitura dos anéis de crescimento dos otólitos sagitta (Capítulo 3).

\section{Histologia}

Foram selecionadas larvas dos dois cruzeiros, totalizando 84 indivíduos, contemplando: as quatro subáreas de coleta (cabo de São Tomé, cabo Frio, baía de Guanabara e Ubatuba); a plataforma interna, externa e talude; e os diferentes estágios de desenvolvimento larval. Para o estudo histológico, as larvas foram desidratadas em série crescente de álcool etílico, diafanizadas em xilol, embebidas e emblocadas, posteriormente, em parafina (Figura 3.1). Os cortes histológicos de 5,0 $\mu \mathrm{m}$ de espessura foram obtidos em plano sagital. Para cada indivíduo foram obtidas no mínimo 10 lâminas para garantir que os tecidos dos órgãos internos, especialmente o fígado, fossem contemplados. Dentre os indivíduos analisados, 18 não apresentaram cortes histológicos que permitissem a avaliação do fígado, e.g. os cortes não foram sagitais ou as larvas eram demasiadamente pequenas.

Duas secções histológicas de cada indivíduo foram selecionadas para montagem de lâminas coradas com hematoxilina e eosina (HE) e Ácido Periódico de Shiff (PAS). O PAS quando em contato com o glicogênio armazenado nas células resulta em uma coloração magenta intensa, sendo possível detectar a sua presença no fígado das larvas. Uma terceira lâmina foi utilizada como contraprova da presença de glicogênio nas células, através do teste com alfa amilase. Essa enzima, também conhecida como diastase, quebra o glicogênio para formação de açúcares solúveis em água, que são lavados e retirados do tecido. Assim a ausência da coloração magenta nos tecidos, que é observada nas lâminas sem tratamento com alfa-amilase, indica a presença de glicogênio, já que esse é removido após o pré-tratamento com essa enzima. 
As lâminas foram observadas sob microscópio óptico, com aumento de 40x e 100x, e fotografadas com máquina digital acoplada. Cada lâmina recebeu um código sem qualquer referência ao local e horário de coleta, cruzeiro ou estágio de desenvolvimento, para evitar qualquer viés na análise das mesmas. No entanto, o estágio de desenvolvimento pode ser deduzido pelo grau de desenvolvimento dos indivíduos, e.g. comprimento e altura do corpo, tamanho dos órgãos internos e flexão da notocorda.

A Tabela 3.1 apresenta os critérios para a classificação histológica dos hepatócitos das larvas de $M$. affine, baseada em critérios descritos para outros teleósteos (Margulies 1993; Diaz, et al., 2011b), em degradado (Figura 3.2A e B), intermediário (Figura 3.2C e D) e saudável (Figura 3.2E e F). O nível de glicogênio nos hepatócitos foi classificado como ausente: não apresenta coloração magenta (Figura 3.3A e B); moderado: coloração magenta muito clara, espaçada ou irregular (Figura 3.3C e D); e alto: coloração magenta intensa espalhada por todo o tecido (Figura 3.3E e F) (O’Connell \& Paloma, 1981; Sieg, 1998). As análises dos níveis de glicogênio e a classificação histológica foram realizadas separadamente para posterior comparação.

\section{Análise de dados}

A frequência de ocorrência das classes histológicas e dos níveis de glicogênio dos hepatócitos foi obtida através da fórmula:

$$
F O=(p / P) \cdot 100
$$

onde:

$\mathrm{FO}$ = frequência de ocorrência;

$p=$ número de observações positivas para a categoria;

$\mathrm{P}=$ número total de observações.

As amostras foram classificadas segundo: a área de coleta: Ubatuba (radiais 1-4), baía de Guanabara (radiais 5-8), cabo Frio (radiais 9-11) e cabo de São Tomé (radiais 12-14) (Introdução Geral, Figura 1); distância da costa: 
plataforma interna (entre a costa e a isóbata de $100 \mathrm{~m}$ ), plataforma externa (entre as isóbatas de 100 e $200 \mathrm{~m}$ ) e talude (além da isóbata de $200 \mathrm{~m}$ ); período de coleta: dia e noite (não foram consideradas as amostras obtidas durante a aurora e o crepúsculo).

O teste não paramétrico de Kruskal-Wallis foi utilizado para detectar diferenças entre as áreas de coleta, distância da costa e estágios de desenvolvimento, em relação às classes histológicas e aos níveis de glicogênio nos hepatócitos. Foram realizadas comparações de Dunn a posteriori, quando necessário (Zar, 1996). Para detectar as diferenças entre os períodos dia e noite e entre os cruzeiros de verão e inverno foi utilizado o teste de Mann-Whitiney. Os resultados das análises foram considerados significativos quando $p<0,05$ (Zar, 1996).

\section{Resultados}

\section{Dados abióticos}

Os dados abióticos estão descritos no Capítulo 1 da presente tese.

Idade e comprimento das larvas de Myctophum affine analisadas

O comprimento padrão das larvas de $M$. affine analisadas variou entre 3,05 e 14,00 mm, com idade entre 3 e 28 dias, baseada na leitura dos anéis de crescimento dos otólitos sagitta (Capítulo 2). A idade das larvas em estágio de pré-flexão $(n=12)$ variou entre 2 e 10 dias, em estágio de flexão $(n=16)$ entre e 7 e 16 dias e em pós-flexão $(n=34)$ entre 11 e 28 dias. Pode-se observar uma grande sobreposição de idade entre os estágios, indicando uma variação individual no tempo de desenvolvimento. A idade cronológica nem sempre indica a idade fisiológica, ou seja, o estágio de desenvolvimento, que depende de diversos fatores, principalmente temperatura, cujo aumento acelera os processos metabólicos e consequentemente o desenvolvimento (Blaxter, 1988). Desse modo, as análises foram realizadas com base nos estágios de desenvolvimento larval (Santamaría et al., 2004; Sieg, 1992b). 


\section{Análise histológica dos hepatócitos}

O número de larvas analisadas provenientes do cruzeiro de verão $(n=45)$ foi superior ao do inverno $(n=19)$. Não houve diferença significativa $(p=0,7079)$ na condição dos hepatócitos entre os dois cruzeiros. Considerando apenas as larvas em pós-flexão, também não houve diferença significativa na condição dos hepatócitos entre os cruzeiros $(p=0,3809)$. Devido ao numero insuficiente de larvas em pré-flexão e flexão analisadas no inverno $(n=5)$, não foi possível realizar o teste estatístico para esses estágios.

A condição histológica dos hepatócitos variou entre as classes apresentadas na Tabela 1. A maioria das larvas (61\%) foi classificada como saudável, 29\% como intermediária e 10\% apresentavam sinais de degradação dos hepatócitos. Analisando cada estágio de desenvolvimento separadamente, foi observada a mesma tendência, com a maioria das larvas classificadas como intermediária ou saudável. As larvas em estágio de pós-flexão apresentaram a menor FO de hepatócitos com sinais de degradação (Tabela 3.2). Houve diferença significativa $(p=0,0413)$ na condição dos hepatócitos entre os diferentes estágios de desenvolvimento (pré-flexão, flexão e pós-flexão). Porém, no teste a posteriori de Dunn, não foi detectada diferença significativa em nenhuma das comparações entre os postos (Tabela 3.3). Somando-se as larvas em pré-flexão e flexão e comparando-se com as larvas em pós-flexão, houve diferença significativa na condição dos hepatócitos entre os estágios de desenvolvimento $(p=0,0321)$.

Analisando a distribuição espacial das larvas, em relação à distância da costa, a FO de larvas saudáveis foi quase duas vezes maior na plataforma externa, em comparação com a plataforma interna e talude, e larvas com sinais de degradação não foram coletadas na plataforma interna (Tabela 3.2). Houve diferença significativa na condição dos hepatócitos entre as regiões com os dados dos dois cruzeiros em conjunto $(p=0,0197)$ e durante o verão $(p=0,0248)$. Porém, no teste a posteriori de Dunn, não foi detectada nenhuma diferença significativa $(p<0,05)$ entre os postos em nenhum dos dois casos (Tabelas 3.4 e 3.5). Durante

o verão, considerando os estágios de desenvolvimento separadamente, houve diferença significativa na condição dos hepatócitos das larvas em estágio de pós- 
flexão ( $p=0,0472$ ), mas no teste a posteriori de Dunn, não foi detectada nenhuma diferença significativa $(p<0,05)$ entre os postos. Não houve diferença significativa entre a plataforma externa e talude na condição dos hepatócitos no conjunto das larvas em estágio de pré-flexão e flexão $(p=0,0981)$.

Em relação ao gradiente latitudinal, a maioria das larvas com sinais de degradação nos hepatócitos foi coletada em Ubatuba, mas não houve diferença significativa na condição dos hepatócitos entre as quatro áreas de coleta, nem durante $o$ verão $(p=0,3036)$ e nem durante o inverno $(p=0,1278)$. Durante $o$ verão, analisando os diferentes estágios separadamente, também não houve diferença significativa entre as áreas de coleta, nem para as larvas em pós-flexão $(p=0,4052)$, nem para o conjunto de larvas em pré-flexão e flexão $(p=0,1134)$.

Comparando as larvas coletadas durante o dia e a noite, considerando os dois cruzeiros, mais de $65 \%$ das larvas foram classificadas como saudáveis e $16 \%$ com sinais de inanição durante o dia, e $66 \%$ saudáveis e $4 \%$ com sinais de inanição durante a noite. Não houve diferença significativa na condição dos hepatócitos entre os dois períodos ( $p=0,5494$ ) (Figura 3.4B).

\section{Níveis de glicogênio}

O nível de glicogênio presente nos hepatócitos, considerando os dois cruzeiros, foi alto em $43 \%$ das larvas, moderado em $26 \%$ e ausente em $31 \%$. Não houve diferença significativa nos níveis de glicogênio presente no fígado das larvas entre os três estágios de desenvolvimento $(p=0,61)$. Também não houve diferença significativa ( $p=0,3603)$ quando os resultados das larvas em estágios pré-flexão e flexão foram agrupados e comparados com os das larvas em pósflexão. No entanto, não foi encontrado sinal de glicogênio em apenas $20 \%$ das larvas em estágio de pós-flexão, enquanto nos estágios de pré-flexão e flexão isso ocorreu em mais de $40 \%$ dos indivíduos (Tabela 3.6).

Houve diferença significativa ( $p=0,0084)$ nos níveis de glicogênio presente nos hepatócitos das larvas entre o dia e a noite, considerando os três estágios de desenvolvimento conjuntamente. Durante a noite houve maior FO de indivíduos com nível alto de glicogênio, enquanto durante o dia a maioria das larvas 
apresentou níveis moderado ou ausente (Tabela 3.6). Considerando os estágios de desenvolvimento separadamente, durante o dia as larvas em pré-flexão e flexão apresentaram maior frequência de nível moderado e ausente, e as larvas em pós-flexão apresentaram praticamente a mesma frequência para os três níveis (Tabela 3.7). Durante a noite, nos três estágios de desenvolvimento, os hepatócitos da maioria dos indivíduos apresentaram nível alto de glicogênio, e nos estágios de flexão e pós-flexão não ocorreram indivíduos sem glicogênio nos hepatócitos (Tabela 3.7). Houve diferença significativa entre os dois períodos apenas para as larvas em pós-flexão $(p=0,042)$, com FO de glicogênio ausente mais elevada entre $9 \mathrm{H} 00$ e $15 \mathrm{H} 00$ (Figura 3.4A).

Analisando a distribuição espacial, não houve diferença significativa nos níveis de glicogênio dos hepatócitos entre as quatro áreas $(p=0,1756)$ e nem entre as regiões relativas à distância da costa $(p=0,4025)$. A FO de cada nível por área e região está apresentada na Tabela 3.7.

Relação entre a análise histológica dos hepatócitos e os níveis de glicogênio

Houve diferença significativa ( $p=0,0251)$ nos níveis de glicogênio entre as diferentes condições histológicas dos hepatócitos. Porém, no teste a posteriori de Dunn, não foi detectada diferença significativa $(p<0,05)$ entre os postos (Tabela 3.8). O número de indivíduos, e a relação entre os dois parâmetros está expressa na Figura 3.5, onde apenas $3,2 \%$ das larvas obtiveram a menor classificação (sinais de degradação e ausência de glicogênio nos hepatócitos), e 36,5\% obtiveram a maior classificação (saudável com nível alto de glicogênio). Nenhuma larva com sinais de degradação nos hepatócitos apresentou nível alto de glicogênio (Figura 3.5). No entanto, mais de 12\% das larvas classificadas como saudáveis não possuíam glicogênio nos hepatócitos (Figura 3.5). 


\section{Discussão}

Análise histológica dos hepatócitos

A maioria das larvas de $M$. affine foi considerada saudável, principalmente as larvas em pós-flexão, nas quais a incidência de sinais de degradação nos hepatócitos foi baixa. Para várias espécies de diferentes ordens de teleósteos, estudos mostram que a resistência das larvas à inanição aumenta com o seu desenvolvimento, e.g. Clupeiformes (O'Connell \& Paloma, 1981; Diaz, et al., 2011), Stomiiformes (Sieg, 1992a), Gadiformes (Theilacker \& Porter, 1995; Grote et al., 2012), Perciformes (Margulies, 1993; Catalán, 2003; Chen et al., 2007) e Pleuronectiformes (Ehrlich et al., 1976). Esse aumento da resistência é devido a fatores associados ao desenvolvimento, como a capacidade locomotora, cujo aumento diminui o gasto energético para natação e aumenta o sucesso no ataque às presas (Yúfera \& Darias, 2007), e à melhora da acuidade visual, que aumenta o número de encontros com as presas (Miller et al., 1993). Dessa maneira, o crescimento e o desenvolvimento elevam o número, a variedade e o tamanho das presas (Sassa, 2010), garantindo um maior estoque de energia.

A alta taxa de indivíduos em boas condições nutricionais pode estar relacionada à eficiência na predação apresentada pelas larvas dessa espécie. A presença de alimento no trato digestório das larvas de Myctophidae é bastante comum (Conley \& Hopkins, 2004; Sassa \& Kawaguchi, 2004, 2005; Sassa, 2010; Bernal et al., 2013), podendo chegar a $100 \%$ dos indivíduos nos estágios mais avançados (Sabatés et al., 2003). As larvas de Myctophum affine possuem olhos elípticos e levemente pedunculados, que thes proporcionam uma melhor acuidade visual, quando comparadas às larvas com olhos arredondados e fixos (Weihs \& Moser 1981). Além disso, apresentam corpo relativamente curto e alto, com cabeça e boca grandes (Moser \& Ahlstrom, 1972; Moser \& Ahlstrom, 1974), muito similares às larvas de Scombridae. Essas larvas costumam consumir presas relativamente grandes e possuem uma forma de ataque mais eficiente do que a utilizada pelas larvas de corpo alongado (Hunter, 1980). No Golfo do México as larvas de $M$. affine alimentam-se principalmente de ostracodas, que são maiores, 
mas menos abundantes e possuem uma estratégia de fuga menos eficiente do que a dos copépodes (Conley \& Hopkins 2004). Segundo esses autores, a preferência por ostracodas deve-se à maior visibilidade, associada à resposta de fuga dessa presa, e à boa acuidade visual que os olhos elípticos proporcionam às larvas de Myctophum. Embora na área do presente trabalho não tenha sido realizado nenhum estudo sobre a dieta da espécie, Ostracoda, que é uma presa em potencial, foi um grupo relativamente abundante nas amostras com características da AT (Oliveira 2009), com a qual M. affine esteve associada (Capítulo 1), indicando que alimento não seria um fator limitante para seu desenvolvimento.

As larvas normalmente mostram boa condição nutricional, e poucos indivíduos, mesmo em pré-flexão, apresentam sinais de inanição severa (O'Connel, 1980; Theilacker, 1986; Diaz, et al., 2011). Contudo, o número de larvas com sinais de degradação pode ser subestimado, pois essas larvas seriam facilmente predadas, e desse modo não seriam capturadas pelas redes de plâncton (Houde, 2002).

Além das causas intrínsecas ao desenvolvimento, altas porcentagens de larvas com sinais de inanição estão associadas às condições oceanográficas locais e a disponibilidade de zooplâncton. Na plataforma do Panamá as más condições das larvas de Scombridae em pré-flexão foram relacionadas com o baixo volume de zooplâncton, observado em épocas com menor incidência de ressurgência e alta precipitação (Margulies, 1993). As larvas de Sardinella brasiliensis apresentaram diferenças na condição nutricional entre duas áreas ao largo de São Sebastião, com maior número de larvas em más condições em área sob influência das águas costeiras (Dias et al., 2004). Na área de estudo as larvas de $M$. affine estão associadas à AT e à mistura entre essa massa de água e a ACAS (Capítulo 1). As larvas são transportadas para a plataforma interna juntamente com a AT, que avança em direção à costa devido aos meandros da CB (Capitulo 1). Desse modo, mesmo quando encontradas na plataforma interna, as larvas devem estar associadas à AT e por isso não houve diferença na condição nutricional das larvas entre as regiões. Contudo, vale ressaltar que a 
maioria das larvas com sinais de degradação nos hepatócitos ocorreu na plataforma externa ao largo de Ubatuba, área com maior influência da AC.

\section{Níveis de glicogênio}

Apenas a presença ou ausência do glicogênio nos hepatócitos não pode ser diretamente relacionada com a condição nutricional das larvas de $M$. affine, pois no presente estudo não houve relação entre as duas variáveis. O'Connell \& Paloma (1981) compararam os resultados da condição nutricional de larvas de Engraulis mordax obtidos através da análise histológica de vários tecidos e da quantidade de glicogênio presente nos hepatócitos, e encontraram relação positiva apenas para as larvas com menos de 7,0 mm CP, quando se tratava de amostras obtidas no ambiente. Os autores atribuíram a fraca associação entre os resultados obtidos nas duas análises à utilização de indivíduos diferentes para cada procedimento, além do aumento da capacidade das larvas maiores de estocar energia. No presente estudo também foi observado que apenas as larvas em estágio de pré-flexão e flexão apresentavam hepatócitos degradados e ausência de glicogênio concomitantemente. Por outro lado, indivíduos saudáveis também apresentaram ausência de glicogênio, independentemente do estágio de desenvolvimento. Contudo, tanto a classificação histológica dos hepatócitos quanto a análise do glicogênio foram realizadas no mesmo indivíduo, excluindo o problema da utilização de indivíduos diferentes observados por O'Connell \& Paloma (1981).

Nas larvas de $M$. affine a quantidade de glicogênio nos hepatócitos parece estar relacionada ao ciclo diário de alimentação, pois com exceção de dois indivíduos em estágio de pré-flexão, durante a noite todas as larvas possuíam glicogênio armazenado nos hepatócitos. A maioria das larvas de mictofídeos é predadora diurna, com alta incidência de alimento durante o dia e ausência durante a noite (Sabatés et al., 2003; Conley \& Hopkins, 2004; Rodríguez-Graña et al., 2005; Sassa \& Kawaguchi, 2005; Sassa, 2010; Bernal et al., 2013). No Golfo do México as larvas de $M$. affine alimentam-se entre o nascer e o pôr do sol, com pico entre $10 \mathrm{H} 00$ e $15 \mathrm{H} 00$ (Conley \& Hopkins 2004), horário em que a ausência 
de glicogênio foi mais frequente nas larvas em pós-flexão do presente estudo. É provável que o nível de glicogênio menor durante o período da manhã seja consequência da ausência de alimentação à noite, pois a reserva de glicogênio deve ter sido consumida nesse período. Em laboratório, nas larvas de Chaenogobius annularis mantidas sem alimento o glicogênio foi reduzido após cinco horas e esgotado após 24 horas (Watanabe, 1985).

Sieg (1998) considerou que o ciclo de alimentação diário não influencia o nível de glicogênio presente nos hepatócitos de Engraulis anchoita, por encontrar níveis altos durante o dia e a noite, e concluiu que não há depleção total do glicogênio quando as larvas possuem alimento suficiente. No entanto, o que chama a atenção nas larvas de $M$. affine não é a presença de glicogênio nos dois períodos, mas a alta frequência de hepatócitos sem glicogênio durante o dia. Essa diferença na frequência de indivíduos sem glicogênio nos hepatócitos entre os períodos poderia ser explicada pelo tempo de digestão. Foi verificado que a digestão em larvas de Leiostomus xanthurus pode ocorrer entre 4 e 5 horas, a $20^{\circ} \mathrm{C}$ (Govoni et al., 1982), e em Thunnus alalunga entre 3 e 4 horas, a $26^{\circ} \mathrm{C}$ (Young \& Davis, 1990). Na área de ressurgência da Corrente de Humboldt, com a temperatura variando entre 16 e $19^{\circ} \mathrm{C}$, duas espécies de Myctophidae (Diogenichthys lanternatus e Triphoturus mexicanus aff. oculleus) apresentaram aproximadamente $65 \%$ das presas não digeridas ao longo do dia (RodríguezGraña et al., 2005). Larvas de $M$. affine e seus congêneres alimentam-se de ostracodas, que são presas relativamente grandes (Conley \& Hopkins 2004) e por isso devem ser mais lentamente digeridas do que rotíferos e náuplios de copépodes, organismos comumente usados em experimentos de laboratório. Supondo que ao entardecer as larvas de $M$. affine ainda possuam aproximadamente $50 \%$ das presas não digeridas, significa que a digestão deve ocorrer nas próximas 4 ou 5 horas do período noturno. Isso explicaria porque elas apresentaram maior nível de glicogênio durante a noite até o amanhecer e o menor nível entre $10 \mathrm{H} 00$ e $15 \mathrm{H} 00$. Próximo ao meio-dia as presas ingeridas pela manhã ainda não teriam sido digeridas, e as reservas de glicogênio obtidas no dia anterior já teriam sido utilizadas. 
Altos níveis de glicogênio encontrados durante o dia nas larvas em pósflexão também podem estar relacionados com o aumento da incidência de alimento durante a noite em larvas maiores, como verificado para $M$. asperum (Sassa \& Kawaguchi, 2004), Protomyctophum thompsoni e Diaphus theta (Sassa \& Kawaguchi, 2005). Além disso, é esperado que exista uma variação individual nos níveis de glicogênio ao longo do dia, pois o horário da alimentação e a quantidade de alimento obtida depende da oportunidade de encontro com a presa (Mackenzie et al., 1999), que é bastante variável, devido ao padrão de distribuição em manchas do zooplâncton e ao período refratário na alimentação, ou seja a larva não ingere a presa se estiver saciada (Rothschild, 1991).

A análise histológica mostra a condição da larva por um período de dias, enquanto o nível de glicogênio nos hepatócitos indica a condição por um período de horas (Ferron \& Leggett, 1994). Embora as duas variáveis representem a condição nutricional da larva em períodos de tempo diferentes, observamos que as larvas com sinais de degradação nos hepatócitos apresentaram somente nível baixo ou ausência de glicogênio. Se a larva não consegue se alimentar por um período superior a 24 horas, aparecem sinais de inanição e a larva pode chegar ao ponto de não retorno, quando mesmo na presença de alimento ela é incapaz de consumi-lo ou de digeri-lo, devido à degradação avançada dos tecidos (Watanabe, 1985; Margulies, 1993). Assim, a ausência de glicogênio em larvas com boa condição nutricional pode ser associada ao ciclo diário de alimentação, ou a não ingestão de presas por algumas horas. No entanto, em larvas com sinais de degradação nos hepatócitos, a ausência de glicogênio pode indicar que não houve presas disponíveis por um longo período ou que as larvas estão próximas ao ponto de não retorno, e mesmo que existam presas disponíveis elas já não conseguem se alimentar.

Nesse estudo, considerando que não houve diferença na condição nutricional das larvas de $M$. affine coletadas em diferentes áreas, a hipótese inicialmente levantada, de que haveria diferença, foi refutada. Esse resultado se deve provavelmente a sua associação com a AT em todas as áreas de coleta (Capítulo 1). Portanto, como apenas as larvas nos estágios de pré-flexão e flexão 
mostraram sinais de inanição mais severa, pode-se concluir que a diferença na sua condição nutricional está relacionada ao estágio de desenvolvimento. 
Tabela 3.1: Critérios para a classificação histológica dos hepatócitos de larvas de Myctophum affine, baseado em Margulies (1993) e Diaz et al. (2011b).

\begin{tabular}{|l|l|l|l|}
\hline & Degradado & Intermediário & Saudável \\
\hline Núcleo & $\begin{array}{l}\text { Centralizado; pequeno e } \\
\text { escuro e/ou grande e } \\
\text { muito granular. }\end{array}$ & $\begin{array}{l}\text { Distinto e } \\
\text { centralizado. }\end{array}$ & $\begin{array}{l}\text { Proeminente e } \\
\text { deslocado } \\
\text { lateralmente na } \\
\text { maioria das células. }\end{array}$ \\
\hline Citoplasma & Granular & $\begin{array}{l}\text { Translúcido ou } \\
\text { granular }\end{array}$ & Translúcido \\
\hline Vacúolos & Ausentes & $\begin{array}{l}\text { Ausentes ou } \\
\text { poucos }\end{array}$ & Muitos \\
\hline $\begin{array}{l}\text { Membrana } \\
\text { citoplasmática }\end{array}$ & Indistinguível & Conspícua & Conspícua \\
\hline
\end{tabular}

Tabela 3.2: Frequência de ocorrência (\%) das classes histológicas dos hepatócitos de Myctophum affine em relação aos fatores analisados. $\mathrm{n}=$ número de indivíduos analisados.

\begin{tabular}{lllrrr}
\hline & & $\mathrm{n}$ & Degradado & Intermediário & Saudável \\
\hline \multirow{2}{*}{ Geral } & & 63 & 9,8 & 29,5 & 60,7 \\
\hline \multirow{3}{*}{ Estágio } & pré-flexão & 11 & 16,7 & 33,3 & 50,0 \\
& flexão & 16 & 12,5 & 43,8 & 43,8 \\
& pós-flexão & 34 & 3,1 & 21,9 & 75,0 \\
\hline \multirow{2}{*}{ Cruzeiro } & verão & 45 & 13,3 & 26,7 & 60,0 \\
& inverno & 18 & 5,3 & 31,6 & 63,2 \\
\hline \multirow{2}{*}{ Período } & dia & 37 & 14,3 & 20,0 & 65,7 \\
& noite & 20 & 5,0 & 25,0 & 70,0 \\
\hline \multirow{2}{*}{ Distância } & plataforma interna & 12 & 0,0 & 58,3 & 41,7 \\
da costa & plataforma externa & 32 & 13,3 & 6,7 & 80,0 \\
& talude & 20 & 10,5 & 47,4 & 42,1 \\
\hline \multirow{4}{*}{ Área } & cabo de São Tomé & 13 & 0,0 & 46,2 & 53,8 \\
& cabo Frio & 19 & 5,3 & 36,8 & 57,9 \\
& baía de Guanabara & 12 & 0,0 & 23,1 & 76,9 \\
& Ubatuba & 19 & 31,6 & 10,5 & 57,9 \\
\hline
\end{tabular}


Tabela 3.3: Resultados do teste de Kruska-Wallis e teste a posteriori de Dunn para a condição dos hepatócitos de Myctophum affine entre os estágios de desenvolvimento préflexão, flexão e pós-flexão. ns= não significativo.

\begin{tabular}{|c|c|c|c|c|}
\hline & Resultados & & & \\
\hline$H=$ & 6.372 & & & \\
\hline Graus de liberdade $=$ & 2 & & & \\
\hline (p) Kruskal-Wallis = & 0.0413 & & & \\
\hline pré-flexão & 322 & & & \\
\hline flexão & 408.5 & & & \\
\hline pósflexão & 1222.5 & & & \\
\hline pré-flexão (posto médio) $=$ & 26.8333 & & & \\
\hline flexão (posto médio) = & 25.5313 & & & \\
\hline pós-flexão (posto médio) = & 35.9559 & & & \\
\hline $\begin{array}{l}\text { Comparações (método de } \\
\text { Dunn) } \\
\text { Postos médios pré-flexão e }\end{array}$ & Dif. Postos & z calculado & z crítico & $\mathrm{p}$ \\
\hline $\begin{array}{l}\text { flexão } \\
\text { flos pre-llexao e }\end{array}$ & 1.3021 & 0.189 & 2.394 & ns \\
\hline $\begin{array}{l}\text { Postos médios pré-flexão e } \\
\text { pós-flexão } \\
\text { Postos médios flexão e pós- }\end{array}$ & 9.1225 & 1.5059 & 2.394 & ns \\
\hline flexão & 10.4246 & 1.9059 & 2.394 & ns \\
\hline
\end{tabular}

Tabela 3.4: Resultados do teste de Kruska-Wallis e teste a posteriori de Dunn para a condição dos hepatócitos de Myctophum affine entre as regiões de coleta, englobando as amostras dos dois cruzeiros. $\mathrm{Pl}=$ plataforma interna, $\mathrm{PE}=$ plataforma externa e $\mathrm{T}=$ talude. ns= não significativo.

\begin{tabular}{|c|c|c|c|c|}
\hline \multicolumn{5}{|c|}{ Resultados } \\
\hline $\mathrm{H}=$ & 7.8579 & & & \\
\hline Graus de liberdade $=$ & 2 & & & \\
\hline (p) Kruskal-Wallis = & 0.0197 & & & \\
\hline $\mathrm{PI}$ & 340.5 & & & \\
\hline PE & 1219 & & & \\
\hline$T$ & 520.5 & & & \\
\hline $\mathrm{PI}($ posto médio $)=$ & 28.375 & & & \\
\hline PE $($ posto médio $)=$ & 38.0938 & & & \\
\hline$T$ (posto médio $)=$ & 26.025 & & & \\
\hline Comparações (método de Dunn) & Dif. Postos & z calculado & z crítico & $\mathrm{p}$ \\
\hline Postos médios PI e PE & 9.7188 & 1.542 & 2.394 & ns \\
\hline $\begin{array}{l}\text { Postos médios } \mathrm{Pl} \mathrm{e} \mathrm{T} \\
\text { Postos médios PE e T }\end{array}$ & $\begin{array}{r}2.35 \\
12.0688\end{array}$ & $\begin{array}{r}0.3457 \\
2.274 \\
\end{array}$ & $\begin{array}{l}2.394 \\
2.394\end{array}$ & $\begin{array}{l}\text { ns } \\
\text { ns }\end{array}$ \\
\hline
\end{tabular}


Tabela 3.5: Resultados do teste de Kruska-Wallis e teste a posteriori de Dunn para a condição dos hepatócitos de Myctophum affine entre as regiões de coleta, durante o cruzeiro de verão. $\mathrm{Pl}=$ plataforma interna, $\mathrm{PE}=$ plataforma externa e $\mathrm{T}=$ talude. ns= não significativo.

\begin{tabular}{|c|c|c|c|c|}
\hline \multicolumn{5}{|c|}{ Resultados } \\
\hline $\mathrm{H}=$ & 7.3912 & & & \\
\hline Graus de liberdade $=$ & 2 & & & \\
\hline (p) Kruskal-Wallis = & 0.0248 & & & \\
\hline PI & 101.5 & & & \\
\hline PE & 586.5 & & & \\
\hline $\mathrm{T}$ & 347 & & & \\
\hline $\mathrm{PI}$ (posto médio) $=$ & 20.3 & & & \\
\hline PE (posto médio $)=$ & 27.9286 & & & \\
\hline$T$ (posto médio) $=$ & 18.2632 & & & \\
\hline Comparações (método de Dunn) & Dif. Postos & z calculado & z crítico & $\mathrm{p}$ \\
\hline Postos médios PI e PE & 7.6286 & 1.1672 & 2.394 & ns \\
\hline Postos médios PI e T & 2.0368 & 0.3085 & 2.394 & ns \\
\hline Postos médios PE e T & 9.6654 & 2.3242 & 2.394 & ns \\
\hline
\end{tabular}

Tabela 3.6: Frequência de ocorrência (\%) dos níveis de glicogênio nos hepatócitos de Myctophum affine em relação aos fatores analisados. $\mathrm{n}=$ número de indivíduos analisados.

\begin{tabular}{llcccc}
\hline & & $\mathrm{n}$ & Ausente & Baixo & Alto \\
\hline Geral & & 66 & 31.8 & 25.4 & 42.9 \\
\hline \multirow{3}{*}{ Estágio } & pré & 12 & 41.7 & 16.7 & 41.7 \\
& flexão & 18 & 44.4 & 11.1 & 44.4 \\
& pós & 34 & 21.9 & 34.4 & 43.8 \\
\hline \multirow{2}{*}{ Cruzeiro } & verão & 48 & 35.4 & 27.1 & 37.5 \\
& inverno & 18 & 16.7 & 27.8 & 55.6 \\
\hline \multirow{2}{*}{ Período } & dia & 38 & 41.7 & 25.0 & 33.3 \\
& noite & 21 & 10.0 & 25.0 & 65.0 \\
\hline \multirow{2}{*}{ Distância } & plataforma interna & 14 & 42.9 & 28.6 & 28.6 \\
& plataforma externa & 32 & 33.3 & 20.0 & 46.7 \\
& talude & 20 & 21.1 & 31.6 & 47.4 \\
\hline \multirow{2}{*}{ Área } & Ubatuba & 19 & 47.4 & 26.3 & 26.3 \\
& baía de Guanabara & 13 & 7.7 & 38.5 & 53.8 \\
& cabo Frio & 19 & 31.6 & 21.1 & 47.4 \\
& cabo de São Tomé & 15 & 26.7 & 26.7 & 46.7 \\
\hline
\end{tabular}


Tabela 3.7: Frequência de ocorrência (\%) dos níveis de glicogênio nos hepatócitos de Myctophum affine em relação ao estágio de desenvolvimento e período do dia. $\mathrm{n}=$ número de indivíduos analisados.

\begin{tabular}{rlcccc}
\hline Período & Estágio & $\mathrm{n}$ & Ausente & Baixo & Alto \\
\hline \multirow{5}{*}{ dia } & pré-flexão & 6 & 50.0 & 33.3 & 16.7 \\
& flexão & 13 & 46.2 & 15.4 & 38.5 \\
& pós- & & & & \\
& flexão & 18 & 35.3 & 29.4 & 35.3 \\
\hline \multirow{5}{*}{ noite } & pré-flexão & 5 & 40.0 & 0.0 & 60.0 \\
& flexão & 3 & 0.0 & 0.0 & 100.0 \\
& pós- & & & & \\
& flexão & 12 & 0.0 & 36.4 & 63.6 \\
\hline
\end{tabular}

Tabela 3.8: Resultados do teste de Kruska-Wallis e teste a posteriori de Dunn para os níveis de glicogênio nos hepatócitos de Myctophum affine entre as classes histológicas dos hepatócitos. ns= não significativo.

\begin{tabular}{|c|c|c|c|c|}
\hline \multicolumn{5}{|c|}{ Resultados } \\
\hline$H=$ & 7.3684 & & & \\
\hline Graus de liberdade $=$ & 2 & & & \\
\hline (p) Kruskal-Wallis = & 0.0251 & & & \\
\hline degradado & 150.5 & & & \\
\hline intermediário = & 443 & & & \\
\hline saudável = & 1422.5 & & & \\
\hline degradado (posto médio) = & 21.5 & & & \\
\hline intermediário (posto médio) = & 26.0588 & & & \\
\hline saudável (posto médio) = & 36.4744 & & & \\
\hline $\begin{array}{l}\text { Comparações (método de Dunn) } \\
\text { Postos médios degradado e }\end{array}$ & Dif. Postos & z calculado & $\begin{array}{c}\mathrm{z} \\
\text { crítico }\end{array}$ & $p$ \\
\hline $\begin{array}{l}\text { intermediário } \\
\text { Postos médios degradado e }\end{array}$ & 4.5588 & 0.5538 & 2.394 & ns \\
\hline $\begin{array}{l}\text { saudável } \\
\text { Postos médios intermediário e }\end{array}$ & 14.9744 & 1.9901 & 2.394 & ns \\
\hline saudável & 10.4155 & 1.9551 & 2.394 & ns \\
\hline
\end{tabular}



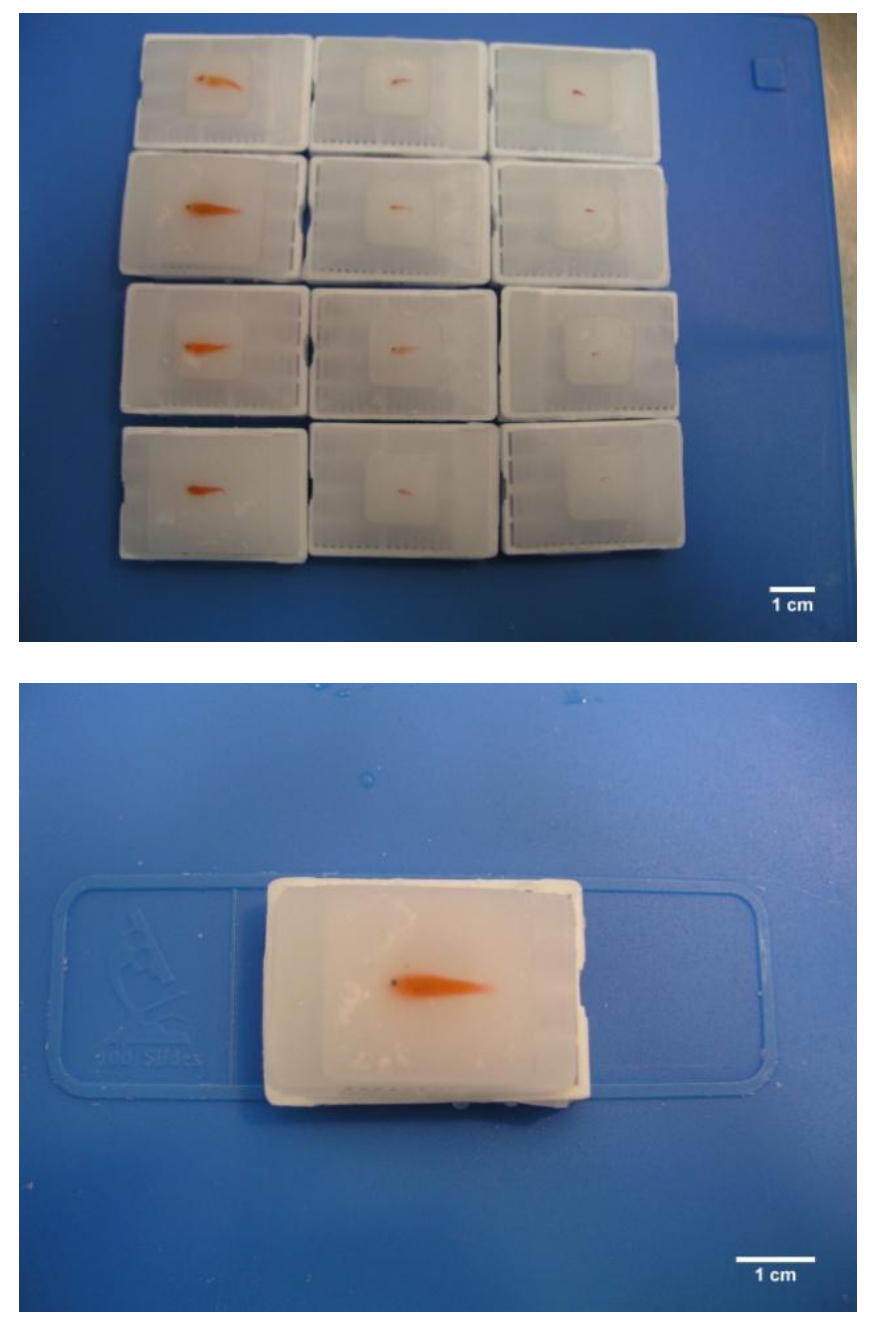

Figura 3.1: Larvas de Myctophum affine coradas previamente com eosina e emblocadas em parafina para a obtenção dos cortes histológicos. 


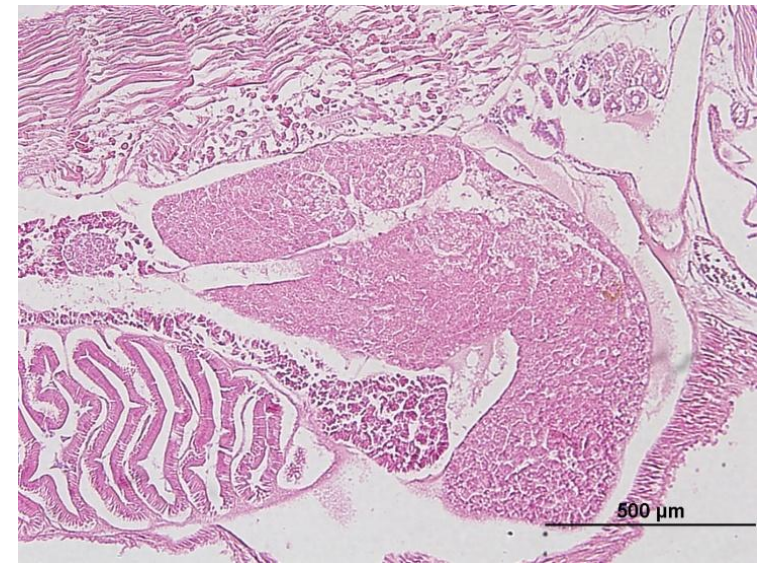

A
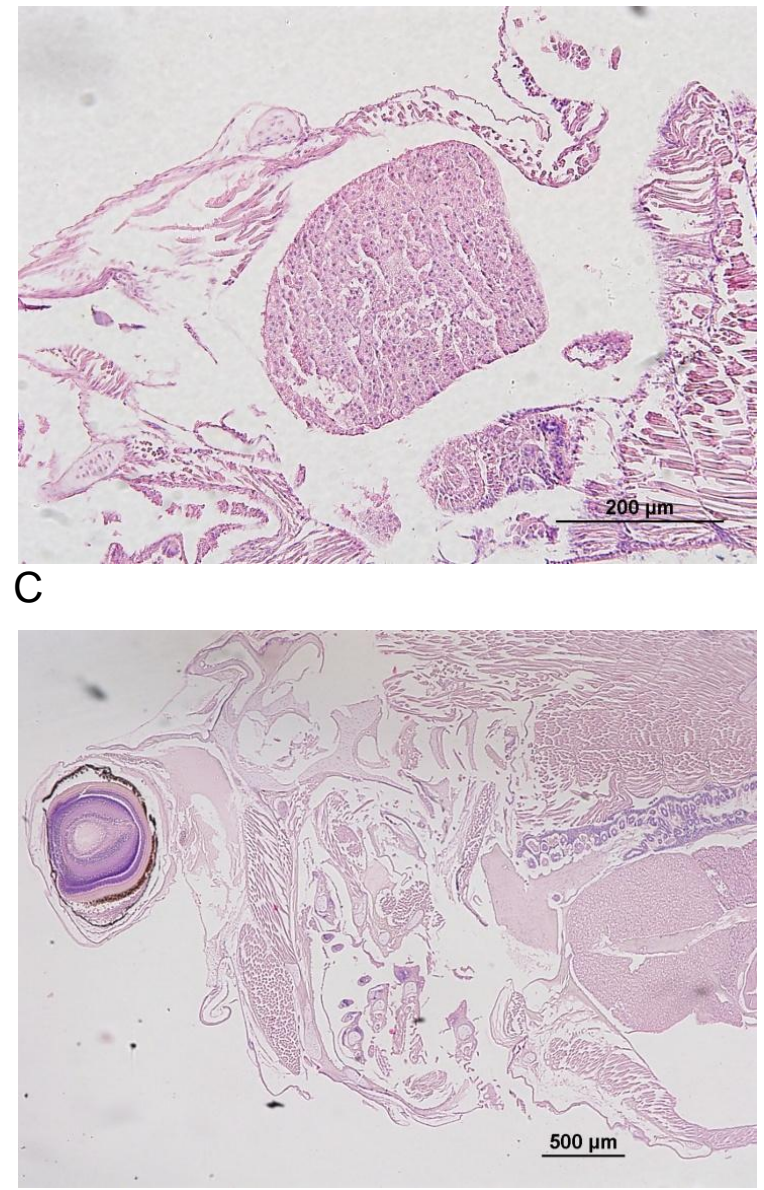

$E$

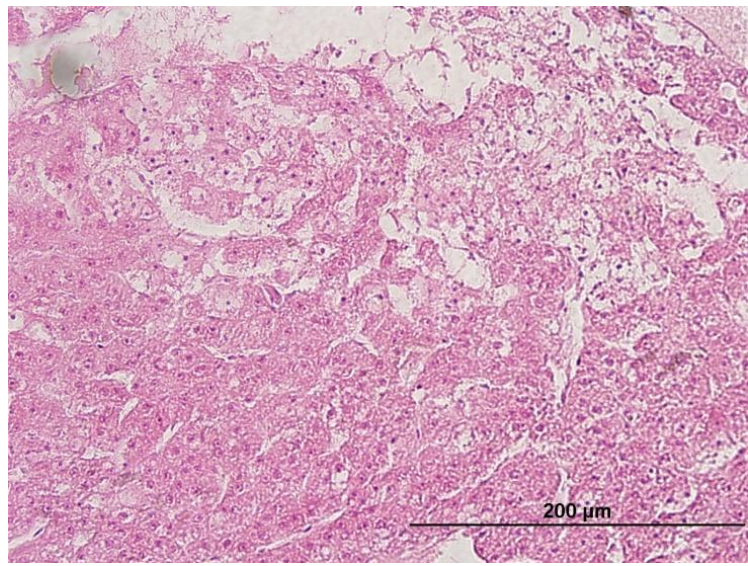

B
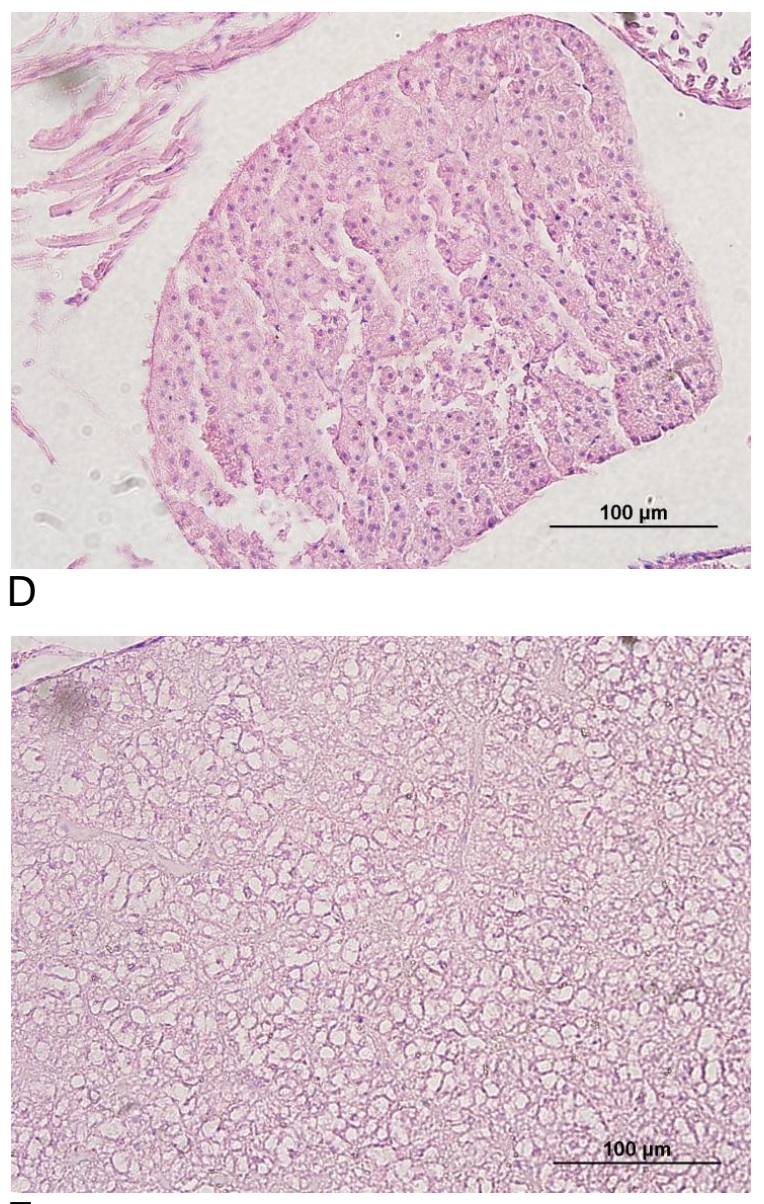

$\mathrm{F}$

Figura 3.2: Cortes histológicos do fígado das larvas de Myctophum affine caracterizando diferentes classes de condição nutricional. Coloração: Hematoxilina Eosina. (A-B) degradada, (C-D) intermediária, (E-F) saudável. 


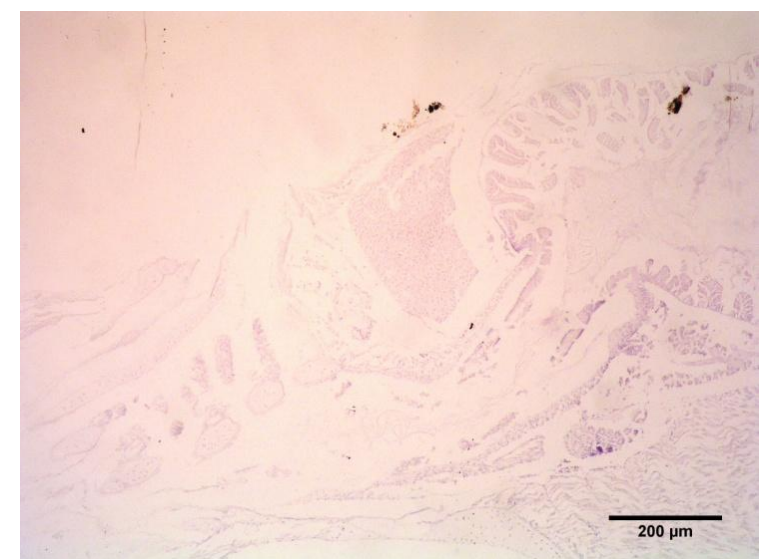

A
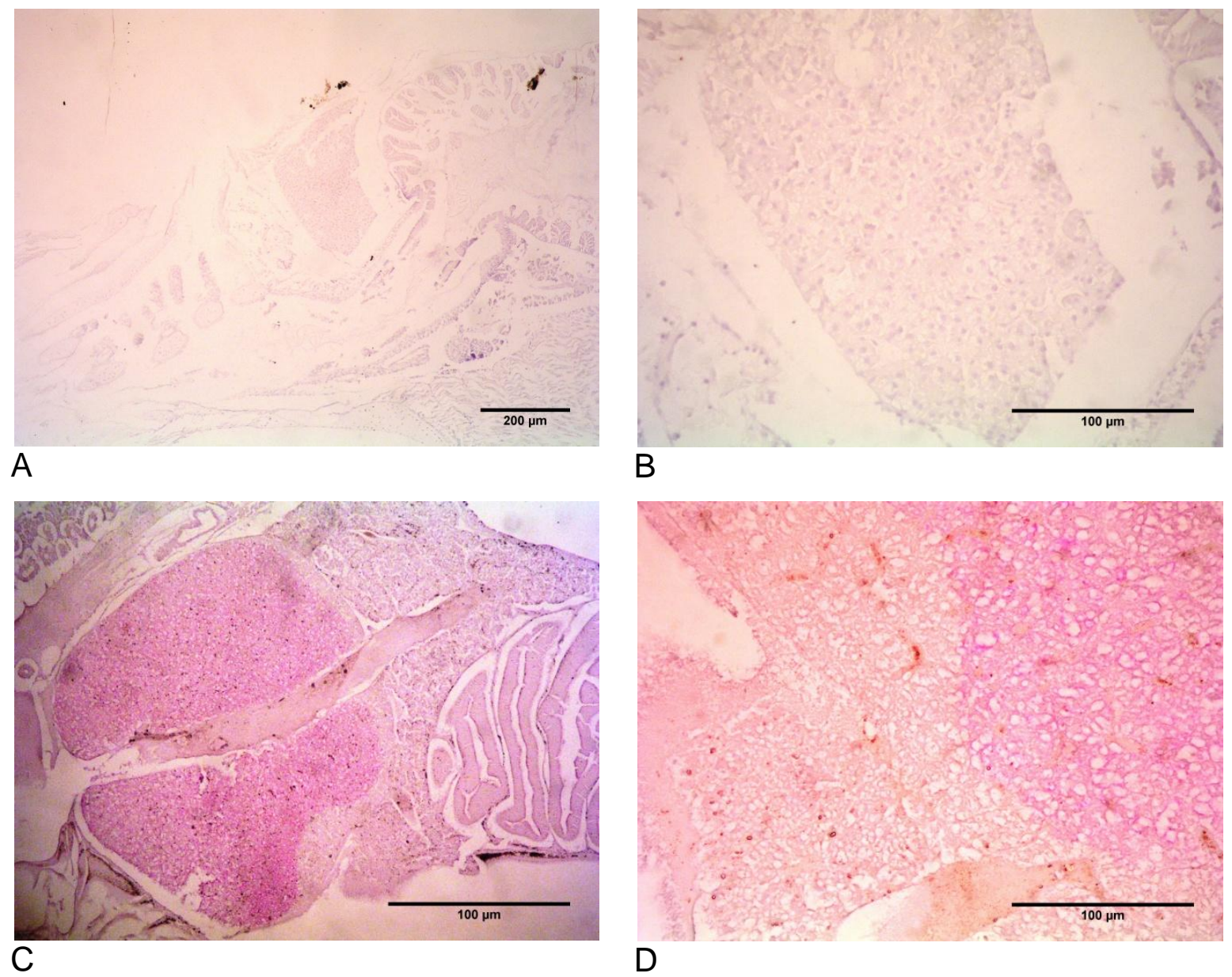

B
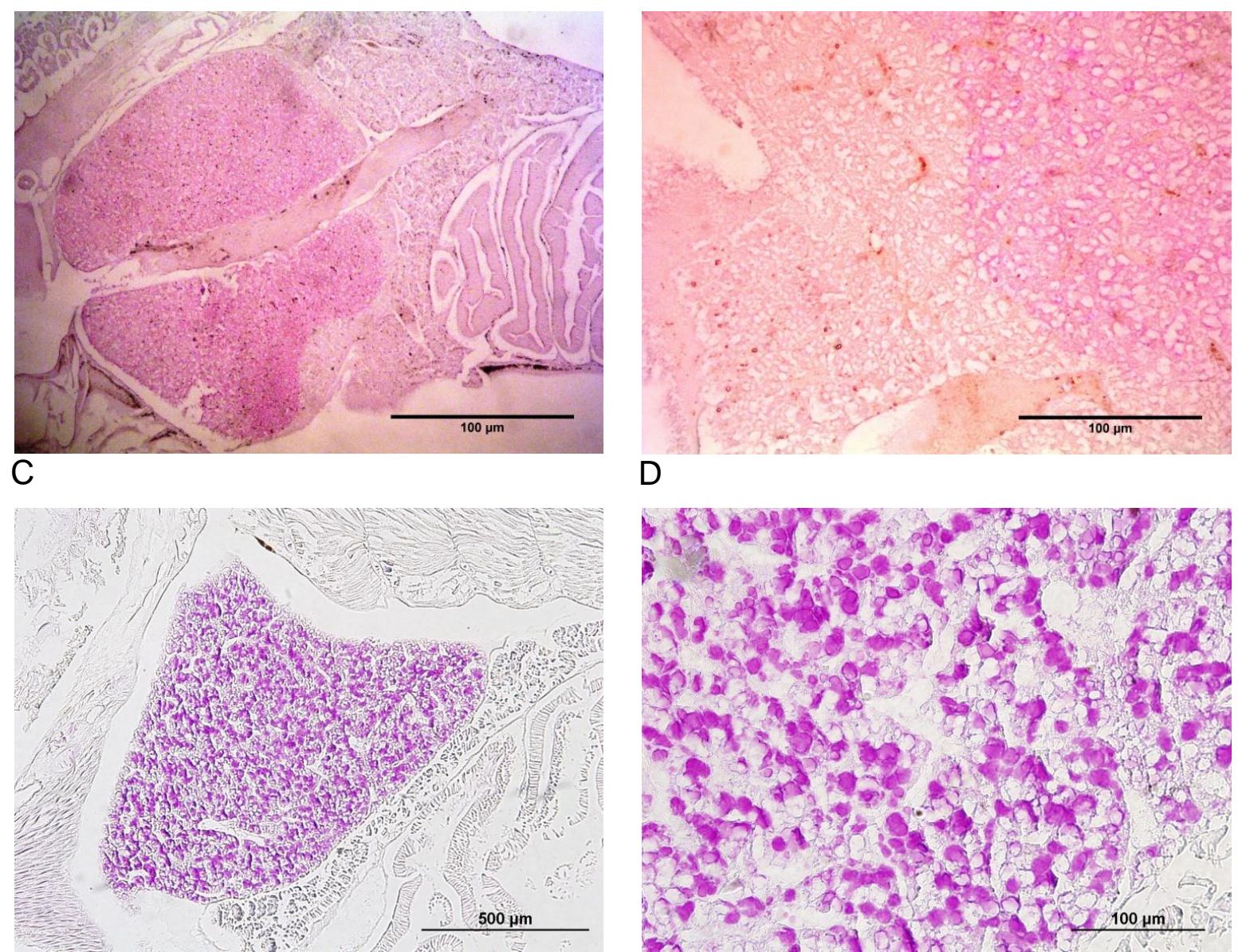

E

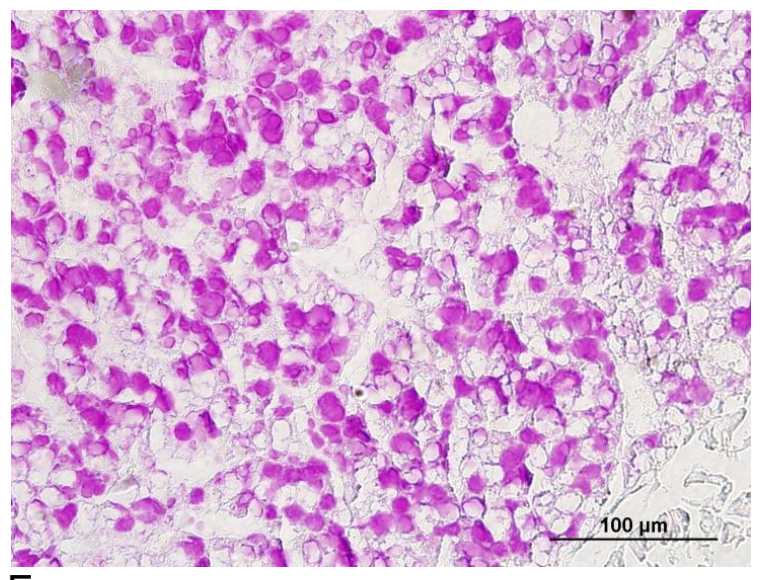
$\mathrm{F}$

Figura 3.3: Cortes histológicos do fígado das larvas de Myctophum affine caracterizando diferentes níveis de glicogênio nos hepatócitos. Coloração: PAS. (A-B) ausente, (C-D) nível baixo , (E-F) nível alto. 
A
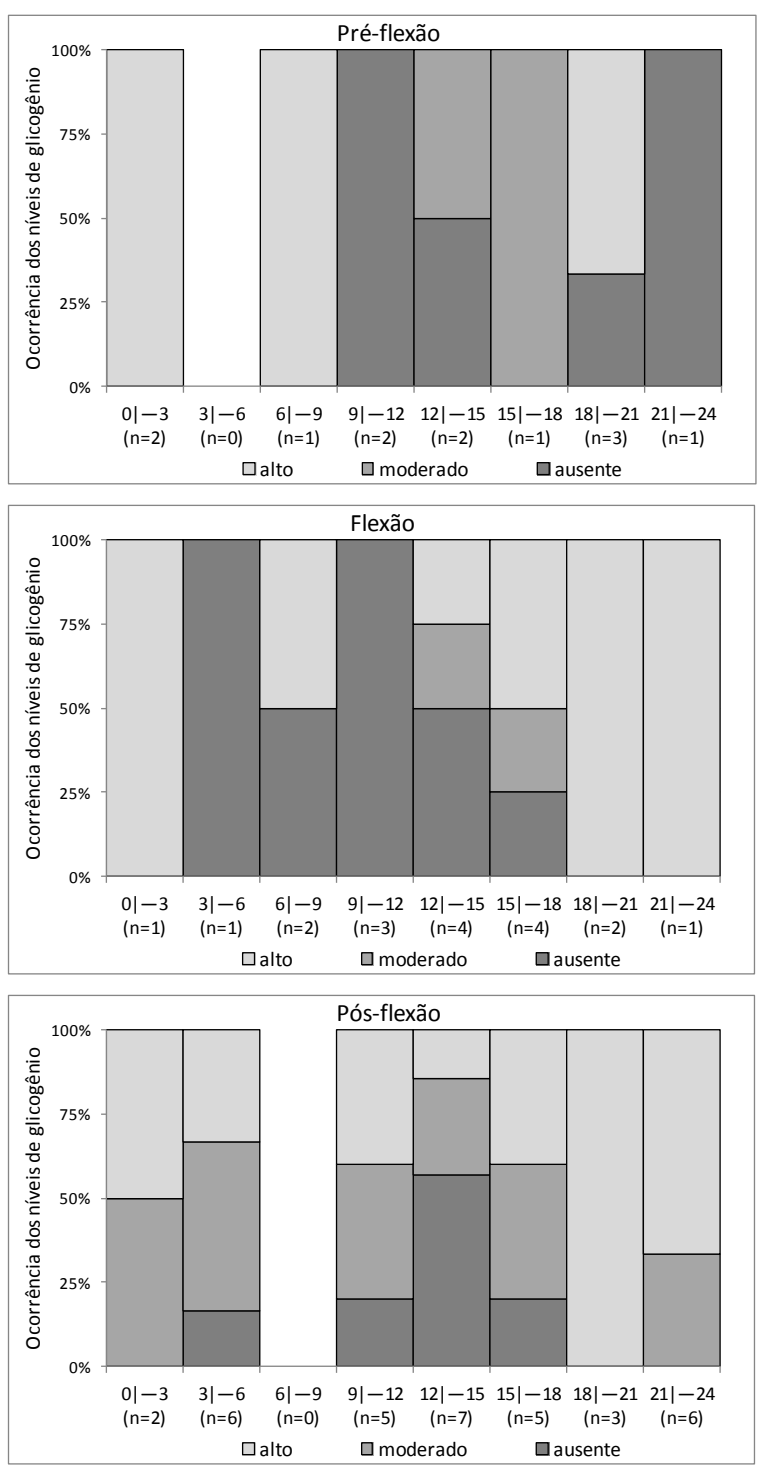

B
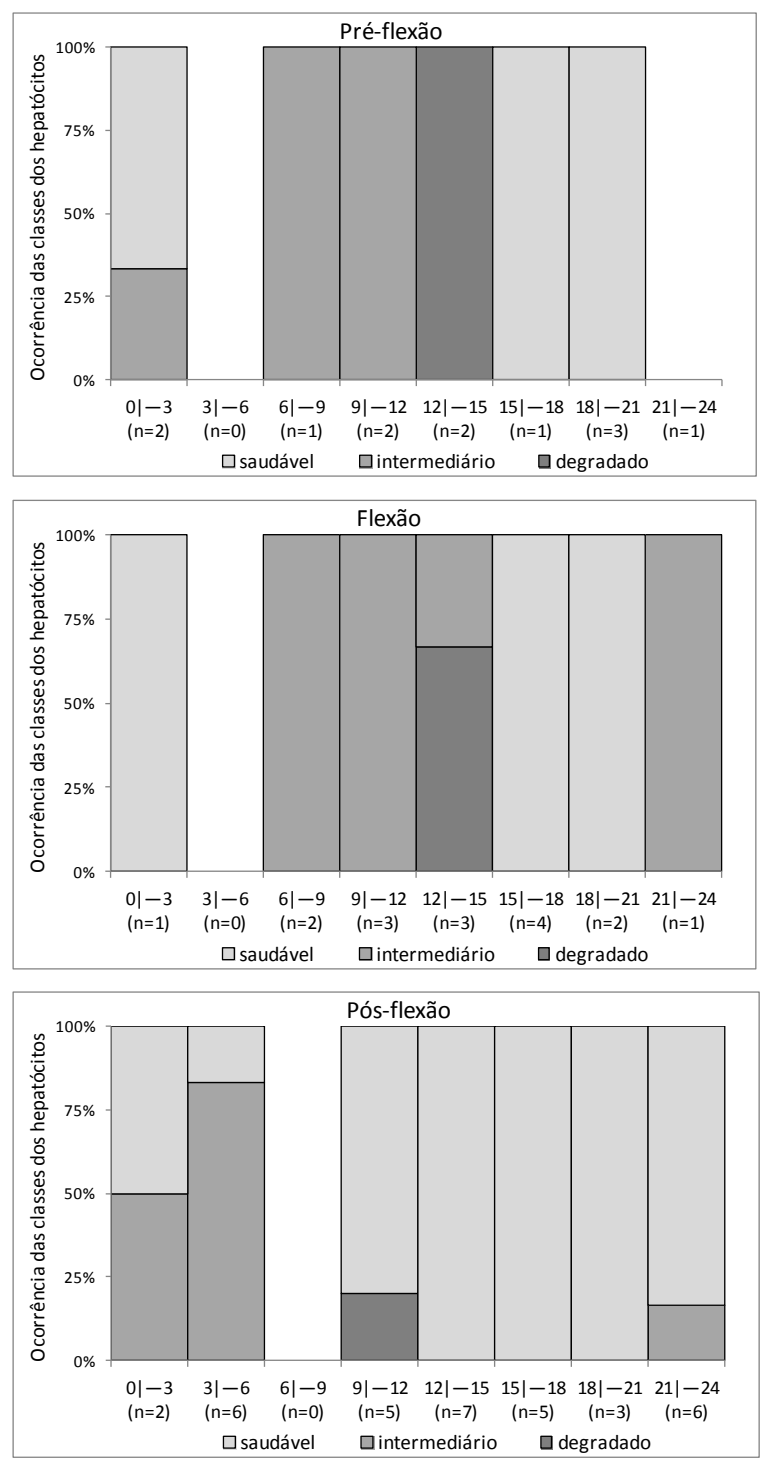

Figura 3.4: (a) Níveis de glicogênio e (b) classificação histológica dos hepatócitos das larvas Myctophum affine em diferentes horários, durante o verão e o inverno de 2002, entre cabo de São Tomé e ilha de São Sebastião. 


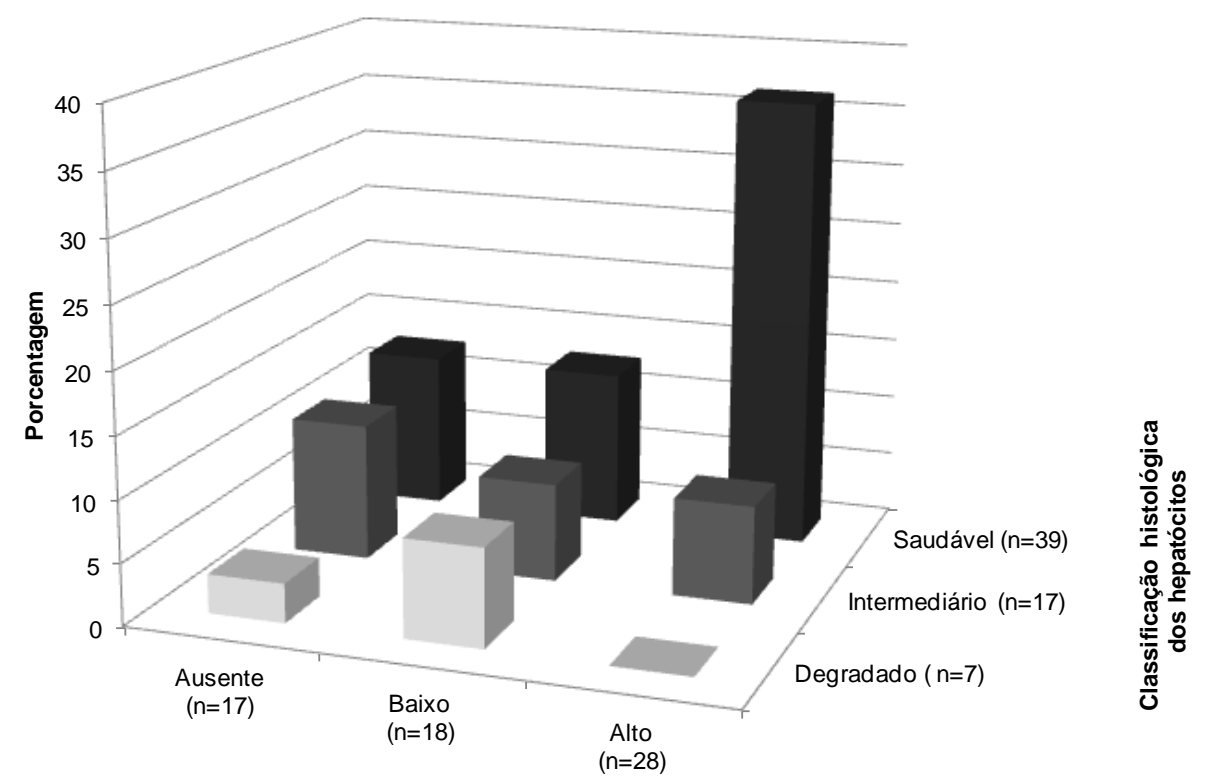

Nível de glicogênio

Figura 3.5: Comparação entre as classes histológicas e os níveis de glicogênio dos hepatócitos de Myctophum affine coletadas durante o verão e o inverno de 2002, entre cabo de São Tomé e ilha de São Sebastião. 


\section{Síntese dos resultados}

As massas de água Água Costeira (AC), Água Tropical (AT) e Água Central do Atlântico Sul (ACAS) estiveram presentes na área de estudo no verão e no inverno. Houve variação espacial e temporal na distribuição e na porcentagem de mistura entre essas massas.

Foram identificados 15 gêneros e 19 espécies ou tipos de peixes-lanterna. $O$ número de espécies identificadas foi similar ao obsevado previamente na região, incluindo aquelas cujas larvas são frequentemente coletadas nas amostras de ictioplâncton, como Myctophum affine e Diaphus spp., e larvas raras como Centrobranchus nigroocelatus e Diogenychthys atlanticus.

Os táxons mais abundantes foram $M$. affine e Diaphus spp. A similaridade morfológica entre as larvas de Diaphus e o grande número de espécies desse gênero presente na área torna impossível a sua identificação em nível de espécie. No entanto, as larvas desse gênero foram classificadas como Diaphus tipo slender e Diaphus tipo stubby pela primeira vez na costa brasileira, e apresentaram diferentes padrões de distribuição.

A maioria das espécies foi mais abundante no talude e sua distribuição sobre a plataforma foi associada à intrusão da AT. O processo de ressurgência costeira da ACAS, que foi mais intenso no verão, diminuiu a intrusão da AT sobre a plataforma. Como as larvas de Myctophidae foram associadas à AT, esse processo reduziu também a ocorrência dessas larvas na plataforma.

A abundância de larvas da família Myctophidae foi maior no verão. No entanto, esse padrão não foi observado para todas as espécies. Algumas foram mais abundantes ou ocorreram somente no inverno: Lobianchia gemellari, Benthosema suborbitale, Diaphus tipo slender, Hygophum hygomii, Lepidophanes guentheri, Lampanyctus tipo 1, Lampanyctus tipo 2 e Notoscopelus causdipinosus. 
Myctophum affine foi a única espécie significativamente mais abundante no verão.

As espécies apresentaram diferentes padrões de distribuição vertical relacionados a maior ou menor proporção de AT nos estratos de coleta.

Myctophum affine foi selecionada para a análise de crescimento, mortalidade e condição nutricional devido a sua maior abundância em relação às demais espécies identificadas.

A contagem dos anéis de crescimento dos otólitos sagitta mostrou que a idade das larvas de $M$. affine variou entre dois e 28 dias.

Os modelos de Laird-Gompertz e exponencial foram considerados representativos o crescimento das larvas de $M$. affine, e os parâmetros obtidos através desses dois modelos foram mais próximos entre si do que os obtidos através do modelo linear.

Segundo o modelo Laird-Gompertz, o comprimento padrão hipotético estimado para a larva de $M$. affine no momento da eclosão foi de $2,57 \mathrm{~mm}$ e a idade estimada para as larvas em estágio de transformação foi de aproximadamente 29 dias.

A taxa de crescimento média $(0,33 \mathrm{~mm} / \mathrm{dia})$ de $M$. affine foi considerada intermediária entre os mictofídeos e a duração de seu período larval uma das menores.

A taxa de mortalidade $(11,8 \%)$ de $M$. affine ficou abaixo da média obsevada para espécies de peixes marinhos, sendo similar a de alguns epipelágicos, como anchoita e chicharro, presentes na região.

A maioria das larvas (61\%) foi classificada como saudável. Apenas 10\% 
apresentaram sinais de degradação nos hepatócitos, dentre as quais a maioria estava em estágio de pré-flexão e flexão.

Não houve diferença significativa entre as áreas na condição nutricional das larvas de $M$. affine. Esse resultado provavelmente se deve a sua associação com a presença da AT, na maioria dos estratos onde foi coletada.

A diferença na condição nutricional de $M$. affine foi relacionada ao estágio de desenvolvimento, pois apenas as larvas em estágio de pré-flexão e flexão mostraram sinais de inanição severa.

Foi detectada diferença significativa entre os períodos diurno e noturno nos níveis de glicogênio nos hepatócitos de $M$. affine, indicando uma associação com o ciclo diário de alimentação. 


\section{Síntese dos Resultados}

As massas de água Água Costeira (AC), Água Tropical (AT) e Água Central do Atlântico Sul (ACAS) estiveram presentes na área de estudo no verão e no inverno. Houve variação espacial e temporal na distribuição e na porcentagem de mistura entre essas massas.

Foram identificados 15 gêneros e 19 espécies ou tipos de peixes-lanterna. O número de espécies identificadas foi similar ao obsevado previamente na região, incluindo aquelas cujas larvas são frequentemente coletadas nas amostras de ictioplâncton, como Myctophum affine e Diaphus spp., e larvas raras como Centrobranchus nigroocelatus e Diogenychthys atlanticus.

Os táxons mais abundantes foram $M$. affine e Diaphus spp. A similaridade morfológica entre as larvas de Diaphus e o grande número de espécies desse gênero presente na área torna impossível a sua identificação em nível de espécie. No entanto, as larvas desse gênero foram classificadas como Diaphus tipo slender e Diaphus tipo stubby pela primeira vez na costa brasileira, e apresentaram diferentes padrões de distribuição.

A maioria das espécies foi mais abundante no talude e sua distribuição sobre a plataforma foi associada à intrusão da AT. O processo de ressurgência costeira da ACAS foi mais intenso no verão, enquanto que a intrusão da AT sobre a plataforma diminuiu neste período. Como as larvas de Myctophidae foram associadas à $\mathrm{AT}$, esse processo reduziu também a ocorrência dessas larvas na plataforma.

A abundância de larvas da família Myctophidae foi maior no verão. No entanto, esse padrão não foi observado para todas as espécies. Algumas foram mais abundantes ou ocorreram somente no inverno: Lobianchia gemellari, Benthosema suborbitale, Diaphus tipo slender, Hygophum hygomii, Lepidophanes guentheri, 
Lampanyctus tipo 1, Lampanyctus tipo 2 e Notoscopelus causdipinosus.

Myctophum affine foi a única espécie significativamente mais abundante no verão.

As espécies apresentaram diferentes padrões de distribuição vertical relacionados a maior ou menor proporção de AT nos estratos de coleta.

A contagem dos anéis de crescimento dos otólitos sagitta mostrou que a idade das larvas de Myctophum affine variou entre dois e 28 dias.

Os modelos de Laird-Gompertz e exponencial foram considerados representativos o crescimento das larvas de $M$. affine, e os parâmetros obtidos através desses dois modelos foram mais próximos entre si do que os obtidos através do modelo linear.

Segundo o modelo Laird-Gompertz, o comprimento padrão hipotético estimado para a larva de $M$. affine no momento da eclosão foi de $2,57 \mathrm{~mm}$ e a idade estimada para as larvas em estágio de transformação foi de aproximadamente 29 dias.

A taxa de crescimento média $(0,33 \mathrm{~mm} / \mathrm{dia})$ de $M$. affine foi considerada intermediária entre os mictofídeos e a duração de seu período larval uma das menores.

A taxa de mortalidade $(11,8 \%)$ de $M$. affine ficou abaixo da média obsevada para espécies de peixes marinhos, sendo similar a de alguns epipelágicos, como anchoita e chicharro, presentes na região.

A maioria das larvas (61\%) foi classificada como saudável. Apenas 10\% apresentaram sinais de degradação nos hepatócitos, dentre as quais a maioria estava em estágio de pré-flexão e flexão. 
Não houve diferença significativa entre as áreas na condição nutricional das larvas de $M$. affine. Esse resultado provavelmente se deve a sua associação com a presença da AT, na maioria dos estratos onde foi coletada.

A diferença na condição nutricional de $M$. affine foi relacionada ao estágio de desenvolvimento, pois apenas as larvas em estágio de pré-flexão e flexão mostraram sinais de inanição severa.

Foi detectada diferença significativa entre os períodos diurno e noturno nos níveis de glicogênio nos hepatócitos de $M$. affine, indicando uma associação com o ciclo diário de alimentação. 


\section{Considerações Finais}

A distribuição das larvas de Myctophidae sobre a plataforma está associada ao processo de intrusão da AT. Desse modo, a intrusão da ACAS, que é mais intensa durante o verão, diminui a extensão da intrusão da AT sobre a plataforma e consequentemente reduz a ocorrência de larvas de Myctophidae nessa região.

Considerando que muitas espécies estão relacionadas à maior proporção de AT, a extensão da distribuição vertical dessas larvas pode diminuir em locais onde há maior porcentagem de AC ou ACAS nos estratos.

Apesar da evidente associação com a AT, os resultados mostram diferentes padrões de distribuição espacial entre as espécies. Portanto, ressalta-se a importância da identificação em nível taxonômico específico para a obtenção de um padrão de distribuição mais refinado, pois o tratamento das espécies como um único grupo pode mascarar diferenças na distribuição vertical e horizontal.

Relacionando a alta abundância e frequência de ocorrência das larvas de $M$. affine com a baixa taxa de mortalidade e a boa condição nutricional observada, pode-se considerar que a plataforma e talude sudeste do Brasil, entre cabo de São Tomé e ilha de São Sebastião, é uma importante área de berçário para essa espécie, e provavelmente para outras espécies da família Myctophidae, cujas larvas estão amplamente distribuídas pela região. 


\section{Referências bibliográficas}

Ahlstrom, E.H., 1959. Vertical distribution of pelagic fish and eggs and larvae off Californiaand Baja California. Fishery Bulletin 60, 107-146.

Albuquerque, C.Q., Muelbert, J.H., Sampaio, L.A.N., 2009. Early developmental aspects and validation of daily growth increments in otoliths of Micropogonias furnieri (Pisces, Sciaenidae) larvae reared in laboratory. Pan-American Journal of Aquatic Sciences 4, 259-266.

Backus, R.H., Craddock, J.E., Haedrich, R.L., Robison, B.H., 1977. Atlantic mesopelagic zoogeography. Fishes of the western North Atlantic. Sears Foundation for Marine Research, Memoir 1, 266- 287.

Bailey, K.M., Houde, E.D., 1989. Predation on eggs and larvae of marine fishes and the recruitment problem. Advances in Marine Biology 25, 1-83.

Bernal, A., Olivar, M.P., Fernández de Puelles, M.L., 2013. Feeding patterns of Lampanyctus pusillus (Pisces: Myctophidae) throughout its ontogenetic development. Marine Biology 160, 81-95.

Bernardes, A.R., Figueiredo, J.L., Rodrigues, A.R., Fisher, L.G., Vooren, C.M., Haimovici, M., Wongtschowski, C.L.D.B., 2005 Peixes da Zona Econômica Exclusiva da região Sudeste-Sul do Brasil: levantamento com armadilhas, redes de arrasto-de-fundo. Editora da Universidade de São Paulo. São Paulo. $295 \mathrm{p}$.

Blaxter, J.H.S., 1988. Pattern and variety in development. In: Fish Physiology Vol XIA. pp. $1-58$.

Bonecker, A.C.T., Castro, M.S., 2006. Atlas de larvas de peixes da região central da Zona Econômica Exclusiva brasileira. Série Livros/Documentos REVIZEE Score Central, $214 \mathrm{p}$. 
Bonecker, A.C.T., Katsuragawa, M., Castro, M.S., Gomes, E.A.P., Namiki, C.A.P., Zani-Teixeira, M.L., 2012. Larval fish of the Campos Basin, southeastern Brazil. Check List 8, 1280-1291.

Bonecker, S.L.C., Nogueira, C.R., Bonecker, A.C.T., Santos, L.H.S., Reynier, M.V., Tenenbaum, D.R., 1992/93. Estudo Hidrográfico e Planctonológico da Região entre Cabo Frio (Rio de Janeiro) e o Arquipélago de Abrolhos (BA). Nerítica Curitiba 7, 71-86.

Borcard, D., Legendre, P., Drapeau, P., 1992. Partialling out the Spatial Component of Ecological Variation. Ecology 73, 1045-1055.

Braga, A.C., Costa, P.A.S., Lima, A.T., Nunan, G.W., Olavo, G., Martins, A.S., 2007. Padrões de distribuição de teleósteos epi- e mesopelágicos na costa central (11-22으) brasileira. In: Costa, P.A.S., Olavo, G., Martins, A.S. (Eds.), Biodiversidade da fauna marinha profunda na costa central brasileira. Rio de Janeiro. Museu Nacional. 184 p.

Braga, A.C., Costa, P.A.S., Nunan, G.W., 2008. First record of the firebrow lanternfish Diaphus adenomus (Myctophiformes: Myctophidae) from the South Atlantic. Journal of Fish Biology 73, 296-301.

Bruscagin, R.T., 2003. Estudo da distribuição, crescimento e estimativa da abundância de Myctophum affine Lütken, 1892 (Myctophidae) na região de cabo Frio (RJ) - Projeto DEPROAS. Iniciação Científica. Instituto Oceanográfico, Universidade de São Paulo. 21 p.

Butler, G.L., Rowland, S.J., Baverstock, P.R., Morris, S., 2012. Ontogenetic behaviour and swimming ability of the endangered eastern freshwater cod, Maccullochella ikei, with notes on growth and development. Ecology of Freshwater Fish 21, 23-33.

Calado L., Silveira, I.C.A., Gangopadhyay, A., Castro, B.M., 2010. Eddy-induced upwelling off Cape São Tomé $\left(22^{\circ} \mathrm{S}\right.$, Brazil). Continental Shelf Research 30, 
1181-1188.

Campana, S.E., 2011. Otolith microstructure preparation http://www.marinebiodiversity.ca/otolith/english/preparation.htm. Acessado pela última vez em 3/05/2013.

Campana, S.E., Jones, C.M., 1992. Analysis of otolith microestructure data, In: Stevenson, D.K., Campana, S.E. (Eds.), Otolith Microestructure Examination and Analysis Canadian Special Pubication of Fisheries and Aquatic Sciences 117. pp. $73-100$.

Campana, S.E., Neilson, J.D., 1985. Microstructure of fish otoliths. Canadian Journal of Fisheries and Aquatic Sciences 42, 1014-1032.

Campos, E.J.D. 1995. Estudos da circulação oceânica no Atlântico Tropical e região oeste do Atlântico Subtropical Sul. Tese de Livre Docência. Universidade de São Paulo. São Paulo, 144 p.

Castelao, R.M., Barth, J.A., 2006. Upwelling around Cabo Frio, Brazil: The importance of wind stress curl. Geophysical Research Letters 33(3).

Castro, B.M., 1987. Condições hidrográficas na plataforma continental ao largo de Ubatuba: variaçoes sazonais e em média escala. Boletim do Instituto de Pesca 35, 135-151.

Castro, B.M., Lorenzzetti, J.A., Silveira, I.C.A.; Miranda, I.B., 2006. Estrutura Termohalina e Circulação na Região entre o Cabo de São Tomé (RJ) e o Chuí (RS). In: Rossi-Wongtschowski C.L.D.B., Madureira. L.S.P. (Eds.), O Ambiente Oceanográfico da Plataforma Continental e do Talude na Região Sudeste-Sul do Brasil. EDUSP. São Paulo. 466 p.

Castro Filho, B.M., 1977. Análise termohalina de massas de água da região oeste do Oceano Atlântico Sul tropical. Dissertação de Mestrado. Universidade de São Paulo. 104 p. 
Castro, B.M., Miranda, L.B., 1998. Physical oceanography of the western Atlantic continental shelf located between $4^{\circ} \mathrm{N}$ and $34^{\circ} \mathrm{S}$ coastal segment $\left(4^{\circ} \mathrm{W}\right)$. In: Robinson, A.R., Brink, K.H. (Eds.), The sea. John Wiley \& Sons. New York. pp. 209-251.

Castro, M.S., Richards, W., Bonecker, A.C.T., 2010. Occurrence and distribution of larval lanternfish (Myctophidae) from the southwest Atlantic Ocean. Zoologia $27,541-553$.

Catalán, I.A., 2003. Conditional indices and their relationship with environmental factors in fish larvae. Tesis Doctoral. Universitat de Barcelona. $265 \mathrm{p}$.

Chen, B.N., Qin, J.G., Carragher, J.F., Clarke, S.M., Kumar, M.S., Hutchinson, W.G., 2007. Deleterious effects of food restrictions in yellowtail kingfish Seriola lalandi during early development. Aquaculture 271, 326-335.

Clemmesen, C., 1996. Importance and limits of RNA/DNA ratios as a measure of nutritional condition in fish larvae. In: Watanabe, Y., Yamashita, Y., Oozeki, Y. (Eds.), Survival strategies in early life stages of marine resources, A.A. Balkema. Rotterdam. pp. 67-82.

Clemmesen, C., Sanchez, R., Wongtschowski, C., 1997. A regional comparison of the nutritional condition of SW Atlantic anchovy larvae, Engraulis anchoita, based on RNA/DNA ratios. Archive of Fishery and Marine Research 45, 1743.

Collins, M.A., Ross, K.A., Belchier, M., Reid, K., 2007. Distribution and diet of juvenile Patagonian toothfish on the South Georgia and Shag Rocks shelves (Southern Ocean). Marine Biology 152, 135-147.

Collins, M.A., Xavier, J.C., Johnston, N.M.J., North, A.W., Enderlein, P., Tarling, G.A., Waluda, C.M., Hawker, E.J., Cunningham, N.J., 2008. Patterns in the distribution of myctophid fish in the northern Scotia Sea ecosystem. Polar Biology 31, 837-851. 
Conley, W.J., Gartner, J.V., 2009. Growth among larvae of lanternfishes (Teleostei: Myctophidae) from the Eastern Gulf of Mexico. Bulletin of Marine Science 84, 123-135.

Conley, W.J., Hopkins, T.L., 2004. Feeding ecology of lanternfish (Pisces: Myctophidae) larvae: prey preferences as a reflection of morphology. Bulletin of Marine Science 75, 361-379.

Cushing, D.H., 1974. The natural regulation of fish populations. In: Harden-Jones, F.R. (Ed.), Sea fisheries research. John Wiley and Sons. New York. pp. 399412.

Cushing, D.H., 1975. Marine ecology and fisheries. Cambridge University Press, Cambridge. 278 p.

Dias, J.F., Clemmesen, C., Ueberschär, B., Rossi-Wongtschowski, C.L.D.B., Katsuragawa, M., 2004. Condition of the Brazilian sardine, Sardinella brasiliensis (Steindachner, 1879) larvae in the São Sebastião inner and middle continental shelf (São Paulo, Brazil). Brazilian Journal of Oceanography 52, $81-87$.

Diaz, M.V., Christiansen, H.E., Pájaro, M., Macchi, G.J., 2011a. Descripción microanatómica de las larvas de Engraulis anchoita y su aplicación en estudios de condición nutricional. Revista de Biología Marina y Oceanografía 46, 431-441.

Diaz, M.V., Pájaro, M., Olivar, M.P., Martos, P., Macchi, G.J., 2011b. Nutritional condition of Argentine anchovy Engraulis anchoita larvae in connection with nursery ground properties. Fisheries Research 109, 330-341.

Dower, J.F., Miller, T.J., Legget, W.C., 1997. The role of microscale turbulence in the feeding ecology of larval fish. Advances in Marine Biology 31, 169-220.

Doyle, M.J., Morse, W.W., Kendall, A.W., Jr., 1993. A comparison of larval fish assemblages in the temperate zone of the northeast Pacific and northwest 
Atlantic oceans. Fisheries Science 53, 588-644.

Ehrlich, K.F., Blaxter, J.H.S., Pemberton, R., 1976. Morphological and histological changes during the growth and starvation of herring and plaice larvae. Marine Biology 35, 105-118.

Ekau, W., 1998. Comparative growth analysis of Engraulis anchoita larvae from southern Brazil. Archieves of Fisheries and Marine Research 46, 1-17.

Ferron, A., Leggett, W.C., 1994. An appraisal of condition measures for marine fish larvae. In: Blaxter, J., Southward, A. (Eds.), Advances in Marine Biology 30, 217-303.

Figueiredo, J.L., Santos, A.P., Yamaguti, N., Bernardes, R.A., RossiWongtschowski, C.L.D.B., 2002. Peixes da Zona Econômica Exclusiva da região Sudeste-Sul do Brasil: levantamento com rede de meia- água. Edusp. São Paulo. 242 p.

Fischer, L.G., 2012. Distribuição, biomassas e ecologia de Macrouridae (Teleostei, Gadiformes) no talude continental do sul do Brasil, com ênfase em Coelorinchus marinii Hubbs 1934 e Malacocephalus occidentalis Goode \& Bean 1885. Tese de Doutorado. Universidade Federal do Rio Grande. 266 p.

Flores-Coto, C., Zavala-García, F., Funes-Rodríguez, R., Espinosa-Fuentes, M.L., Zavala-Hidalgo, J., 2008. Larval abundance variation of Bregmaceros cantori Milliken \& Houde, 1984, related to the El Niño events (1987-1996), southern Gulf of Mexico. Revista de Biología Marina y Oceanografía 43, 91-98.

Foloni Neto, H., 2010. As massas de água na Bacia de Campos, RJ. Dissertação de Mestrado. Universidade de São Paulo. 119 p.

Franco, B.C., Muelbert, J.H., 2003. Distribuição e composição do ictioplâncton na quebra da plataforma do sul do Brasil. Atântica 25, 75-85. 
Franco, B.C., Muelbert, J.H., Mata, M.M., 2006. Mesoscale physical processes and the distribution and composition of ichthyoplankton on the southern Brazilian shelf break. Fisheries Oceanography 15, 37-43.

Gartner, J.V., Jr., 1991a. Life histories of three species of lanternfishes (Pisces: Myctophidae) from the eastern Gulf of Mexico - I. Morfological and microstructural analysis of sagittal otoliths. Marine Biology 111, 11-20.

Gartner, J.V., Jr., 1991b. Life histories of three species of lanternfishes (Pisces: Myctophidae) from the eastern Gulf of Mexico - II. Age and growth patterns. Marine Biology 111, 21-27.

Gartner, J.V., Jr., 1993. Patterns of reproduction in the dominant lanternfish species (Pisces: Myctophidae) of the Eastern Gulf of Mexico, with a review of reproduction among tropical-subtropical Myctophidae. Bulletin of Marine Science 52, 721-750.

Gasalla, M.A., Velasco, G., Rossi-Wongtschowski, C.L.D.B., Haimovici, M., Madureira, L.S.P., 2007. Modelo de equilíbrio de biomassas do ecossistema marinho da Região Sudeste-Sul do Brasil entre 100-1000 m de profundidade. Série documentos Revizee: Score Sul, Instituto Oceanográfico Universidade de São Paulo, São Paulo. 56 p.

Gjøsaeter, J., Kawaguchi, K., 1980. A review of the world resources of mesopelagic fish. FAO Fisheries Technical Paper 193, 151.

Goçalo, C.G., 2008. Distribuição e abundância de larvas de Phosichthyidae e condições oceanográficas na região entre o cabo de São Tomé (RJ) e a ilha de São Sebastião (SP) São Paulo. Dissertação de Mestrado. Universidade de São Paulo. 164p.

Goçalo, C.G., Katsuragawa, M., Silveira, I.C.A., 2011. Patterns of distribution and abundance of larval Phosichthyidae (Actinopterygii, Stomiiformes) in 
southeastern Brazilian waters. Brazilian Journal of Oceanography 59, 213229.

Govoni, J.J., Peters, D.S., Merriner, J.V., 1982. Carbon assimilation during larval development of the marine teleost Leiostomus xanthurus Lacépède. Journal of Experimental Marine Biology and Ecology 64, 287-299.

Gray, C., Miskiewicz, A.G., 2000. Larval fish assemblages in South-East Australian coastal waters: seasonal and spatial structure. Estuarine, Coastal and Shelf Science 50, 549-570.

Grote, B., Ekau, W., Stenevik, E.K., Clemmesen, C., Verheye, H.M., Lipinski, M.R., Hagen, W., 2012. Characteristics of survivors: growth and nutritional condition of early stages of the hake species Merluccius paradoxus and M. capensis in the southern Benguela ecosystem. ICES Journal of Marine Science 69, 553562.

Harden-Jones, F.R., 1968. Fish migration. Edward Arnold, London. 325 p.

Hayashi, A., Kawaguchi, K., Watanabe, H., Ishida, M., 2001a. Daily growth increment formation and its lunar periodicity in otoliths of the myctophid fish Myctophum asperum (Pisces: Myctophidae). Fisheries Science 67, 811-817.

Hayashi, A., Watanabe, H., Ishida, M., Kawaguchi, K., 2001b. Growth of Myctophum asperum (Pisces: Myctophidae) in the Kuroshio and transitional waters. Fisheries Science 67, 983-984.

Hewitt, R.P., Brewer, G.D., 1983. Near shore production of young anchovy. California Cooperative Oceanic Fisheries Investigations Reports XXIV, 235244.

Holliday, D., Beckley, L. E., Olivar, M. P., 2011. Incorporation of larval fishes into a developing anti-cyclonic eddy of the Leeuwin Current off south-western Australia. Journal of Plankton Research 33, 1696-1708. 
Hopkins, T.L., Sutton, T.T., Lancraft, T.M., 1996. The trophic structure and predation impact of a low latitude midwater fish assemblage. Progress In Oceanography 38, 205-239.

Houde, E.D., 2002. Mortality. In: Fuiman, L.A., Werner, R.G. (Eds.), Fishery Science: The unique contributions of early life stages. Blackwell Scence Ltd. Oxford. pp. 64-87.

Houde, E.D., 2009. Recruitment variability. In: Jakobsen, T., Megrey, A.B., Mokness, E. (Eds.), Fish Reproductive Biology. Wiley-Blackwell. Oxford. pp. 91-171.

Houde, E.D., Zastrow, C.E., 1993. Ecosystem- and taxon-specific dynamic and energetics properties of larval fish assemblages. Bulletin of Marine Science 53, 290-335.

Hulley, P.A., 1981. Results of the research cruises of FRV "Walther Herwig" to South America. LVIII. Family Myctophidae (Osteichthyes, Myctophiformes). Archiv für Fischereiwissenschaft 31, 1-300.

Hulley. P.A., 1994. Lanternfishes. In: Paxton, M., Eschmeyer, W.N. (Eds.), Encyclopedia of Fishes. Academic Press. San Diego. pp. 127-128.

Hunt von Herbing, I., Gallager, S.M., Halteman, W., 2001. Metabolic costs of pursuit and attack in early larval Atlantic cod. Marine Ecology Progress Series 216, 201-212.

Hunter, J.R., 1980. Feeding ecology and predation of marine fish larvae. In: Marine Fish Larvae Morphology, Ecology and Relation to Fisheries. Washingtos Sea Grant Program. Seatle and London. pp. 33-77.

Hurst, T.P., Laurel, B.J., Ciannelli, L., 2009. Ontogenetic patterns and temperaturedependent growth rates in early life stages of Pacific cod (Gadus macrocephalus). Fishery Bulletin 108, 382-392. 
Itagaki, M.K., 1999. Composição, abundância e distribuição horizontal das assembléias de larvas de peixes marinhos e sua relação com os fatores hidrográficos na Costa Sudeste do Brasil. Dissertação de Mestrado. Universidade de São Paulo. 208 p.

Itagaki, M.K., 2005. Potencial de recrutamento da larvas e juvenis de Robalo-peva, Centropomus parallelus (Teleostei: Centropomidae) no sistema CananéiaIguape, São Paulo, Brasil. Tese de Doutorado.Universidade de São Paulo. $159 \mathrm{p.}$

Joh, M., Matsuda, T., Satoh, N., Tanaka, N., Ueda, Y., 2011. Otolith microstructure of brown sole Pseudopleuronectes herzensteini: validation of daily ring formation and the occurrence of microstructure denoting metamorphosis. Fisheries Science 77, 773-783.

Jones, C., 1986. Determining age of larval fish with the otolith increment technique. Fishery Bulletin 84, 91-103.

Kamler, E., 1992. Early life history of Fish: an energetics approach. Chapman \& Hall, London. 267 p.

Katsuragawa, M., 2007. Ictioplâncton na região da quebra da plataforma continental do Sudeste Brasileiro. Tese de Livre Docência. Universidade de São Paulo. 310 p.

Katsuragawa, M., Ekau, W., 2003. Distribution, growth and mortality of young rough scad, Trachurus lathami, in the south-eastern Brazilian Bight. Journal of Applied Ichthyology 19, 21-28.

Kitahara, E.M., Matsuura, Y., 1995. Growth and mortality estimate of the southwest Atlantic anchovy Engraulis anchoita larvae from Cape Santa Marta Grande in southern Brazil. Archieves of Fisheries and Marine Research 42, 251-262.

Kobyliansky, S.G., Orlov, A.M., Gordeeva, N.V., 2010. Composition of deepsea 
pelagic ichthyocenes of the Southern Atlantic, from waters of the range of the Mid Atlantic and Walvis Ridges. Journal of Ichthyology 50, 932-949.

Kohno, H., Hara, S., Duray, M., Gallego, A., 1988. Transition from endogenous to exogenous nutrition sources in larval rabbitfish Siganus guttatus. Nippon Suisan Gakkaishi 54, 1083-1091.

Kramer, D., Zweifel, J.R., 1970. Growth of anchovy larvae (Engraulis mordax Girard) in the laboratory as influenced by temperature. Calif. Mar. Res. Comm., CalCOFI Reports 14, 84-87.

Kurtz, F.W., 1999. Dinâmica larval de Sardinella brasiliensis (Steindachner, 1879) (Teleostei, Clupeidae) na região sudeste do Brasil e implicações no recrutamento. Tese de Doutorado. Universidade de São Paulo. 169 p.

Laird, A.K., Tyler, S.A., Barton, A.D., 1965. Dynamics of normal growth. Growth 29, 233-248.

Leis, J.M., 1993. Larval fish assemblages near Indo-Pacific coral reefs. Bulletin of Marine Science 53, 362-392.

Loeb, V.J., 1979. Vertical distribution and development of larval fishes in the North Pacific Central Gyre during summer. Fishery Bulletin 77, 777-793.

Lopes, C.L., 2006. Variação espaço-temporal do ictioplâncton e condições oceanográficas na região de Cabo Frio (RJ). Tese de doutorado. Universidade de São Paulo. 197 p.

Lopes, R.M., Katsuragawa, M., Dias, J.F., Montú, M.A., Muelbert, J.H., Gorri, C., Brandini, F.P., 2006. Zooplankton and ichthyoplankton distribution on the southern Brazilian shelf : an overview. Scientia Marina 70, 189-202. 
Mackenzie, B.R., Ueberschar, B., Basford, D., Heath, M., Gallego, A., 1999. Diel variability of feeding activity in haddock (Melanogrammus aeglifinus) larvae in the East Shetland area, North Sea. Marine Biology 135, 361-368.

Marancik, K.E., Clough, L.M., Hare, J.A., 2005. Cross-shelf and seasonal variation in larval fish assemblages on the southeast United States continental shelf off the coast of Georgia. Fishery Bulletin 103, 108-129.

Margulies, D., 1993. Assessment of the nutritional condition of larval and early juvenile tuna and Spanish mackerel (Pisces: Scombridae) in the Panamá Bight. Marine Biology 115, 317-330.

Martell, D.J., Kieffer, J.D., Trippel, E.A., 2005. Effects of temperature during early life history on embryonic and larval development and growth in haddock. Journal of Fish Biology 66, 1558-1575.

Matsuura, Y., 1983. Estudo comparativo das fases iniciais do ciclo de vida da sardinha-verdadeira, Sardinella brasiliensis e da sardinha-cascuda, Harengula jaguana (Pisces: Clupeidae) e nota sobre a dinâmica da população da sardinha verdadeira na região Sudeste do Brasil. Tese de Livre Docência. Universidade de São Paulo. 150 p.

Matsuura, Y., Kitahara, E.M., 1995. Horizontal and vertical distribution of anchovy Engraulis anchoita eggs and larvae from Cape Santa Marta Grande in southern Brazil. Archieves of Fisheries and Marine Research 42, 239-250.

Mattos, R.A., Lopes, C.L., Ponsoni, L., Calado, L., Miranda, L.B., Silveira, I.C.A., 2004. Distribuição percentual de massas de água na Plataforma Sudeste Brasileira durante regimes de ressurgência e subsidência costeiras. In: II Simpósio Brasileiro de Oceanografia.

McClain, C.R., Signorini, S.R., Christian, J.R., 2004. Subtropical gyre variability observed by ocean-color satellites. Deep Sea Research Part II: Topical Studies in Oceanography 51, 281-301. 
Methot, R.D., 1981. Spatial covariation of daily growth rates of larval northern anchovy, Engraulis mordax, and northern lampfish, Stenobrachius leucopsaurus. Rapp. P-v. Réun. Cons. int. Explor. Mer 178, 424-431.

Miller, T.J., Crowder, L.B., Rice, J.A., 1993. Ontogenetic changes in behavioural and histological measures of visual acuity in three species of fish. Environmental Biology of Fishes 37, 1-8.

Miranda, L.B., 1982. Análise das massas de água da plataforma continental e da região oceânica adjacente: Cabo de São Tomé (RJ) e a llha de São Sebastião (SP), Brasil. Boletim do Instituto Oceanográfico 33, 105-119.

Moku, M., Hayashi, A., Mori, K., Watanabe, Y., 2005. Validation of daily otolith increment formation in the larval myctophid fish Diaphus slender-type spp. Journal of Fish Biology 67, 1481-1485.

Moku, M., Ishimaru, K., Kawaguchi, K., 2001. Growth of larval and juvenile Diaphus theta (Pisces: Myctophidae) in the transitional waters of the western North Pacific. Ichthyological Research 48, 385-390.

Morel, A., Claustre, H., Gentili, B., 2010. The most oligotrophic subtropical zones of the global ocean: similarities and differences in terms of chlorophyll and yellow substance. Biogeosciences 7, 3139-3151.

Moser, H.G., 1981. Morphological and functional aspects of marine fish larvae. In: Lasker, R. (Ed.), Marine fish larvae: morphology, ecology, and relation to fisheries. Washinton Sea Grant Program. Seatle and London. pp. 89-131.

Moser, H.G., Ahlstrom, E.H., 1972. Development of the lanternfish, Scopelopsis multipunctatus Brauer 1906, with a discussion of its phylogenetic position in the family Myctophidae and its role in a proposed mechanism for the evolution of photophore patterns in lanternfishes. Fishery Bulletin 70, 541-564. 
Moser, H.G., Ahlstrom, E.H., 1974. Role of larval stages in systematic investigations of marine teleosts: The Myctophidae, a case of study. Fishery Bulletin 72, 391-413.

Moser, H.G., Ahlstrom, E.H., 1996. Myctophidae: Lanternfishes. In: Moser, H.G. (Ed.), The Early Stages of Fishes in the California Current Region. La Jolla, Calcofi Atlas 33, 387-475.

Moser. H.G., Ahlstrom, E.H., Paxton, J.R., 1984. Myctophidae: Development. In: Moser, H.G., Richards, W.J., Cohen, D.M., Fahay, M.P., Kendall Jr., A.W., Richardson, S.L. (Eds.), Ontogeny and systematics of fishes. American Society of Ichthyologists and Herpetologists. Special Publication Number 1, 218-239.

Moser, H.G., Smith, P.E., 1993. Larval fish assemblages of the California Current region and their horizontal and vertical distributions across a front. Bulletin of Marine Science 53, 645-691.

Moser, H.G., Watson, W., 2006. Myctophidae: Lanternfishes. In: Richards, W.J. (Ed.), Early Stages of Atlantic Fishes: An Identification Guide for the Western North Atlantic. Volume I. pp. 473-579.

Muhling, B.A., Beckley, L.E., 2007. Seasonal variation in horizontal and vertical structure of larval fish assemblages off south-western Australia, with implications for larval transport. Journal of Plankton Research 29, 967-983.

Muhling, B.A., Beckley, L.E., Gaughan, D.J., Jones, C.M., Miskiewicz, A.G., Hesp, S.A., 2008b. Spawning, larval abundance and growth rate of Sardinops sagax off southwestern Australia: influence of an anomalous eastern boundary current. Marine Ecology Progress Series 364, 157-167.

Muhling, B.A., Beckley, L.E., Koslow, J.A., Pearce, A.F. 2008a. Larval fish assemblages and water mass structure off the oligotrophic south-western Australian coast. Fisheries Oceanography 17, 16-31. 
Muhling, B.A., Beckley, L.E., Olivar, M.P., 2007. Ichthyoplankton assemblage structure in two meso-scale Leeuwin Current eddies, eastern Indian Ocean. Deep Sea Research Part II 54, 1113-1128.

Muto, E.Y., Silva, M.H.C., Vera, G.R., Leite, S.S.M., Navarro, D.G., RossiWongtschowski, C.L.D.B., 2005. Alimentação e relações tróficas de peixes demersais da plataforma continental externa e talude superior da Região Sudeste-Sul do Brasil. Série Documentos Revizee Score Sul Instituto Oceanográfico Universidade de São Paulo, São Paulo. 64 p.

Nafpaktitis, B.G., Backus, R.H., Craddock, J.E., Haedrich. R.L., Robinson, B.H., Karnella, C., 1977. Family Myctophidae. In: Gibbs Jr., R.H. (Ed.), Fishes of the western North Atlantic. Sears Foundation for Marine Research, Memoir 1, 13265.

Nelson, J.R., 2006. Fishes of the World. John Wiley \& Sons. 4rd edition. 600 p.

Neves, V.C., Nolf, D., Clarke, M.R., 2011. Diet of Bulwer's Petrel (Bulweria bulwerii) in the Azores, NE Atlantic. Waterbirds 34, 357-362.

Nishimura, A., Nagasawa, K., Asanuma, T., Aoki, H., Kubota, T., 1999. Age, growth and feeding habits of lanternfish, Stenobrachius leucopsaurus (Myctophidae) collected from the near-surface layer in the Bering Sea. Fisheries Science 65, 11-15.

Nonaka, R.H., Matsuura, Y., Susuki, K., 2000. Seasonal variation in larval fish assemblages in relation to oceanographic conditions in the Abrolhos Bank region off eastern Brazil. Fishery Bulletin 98, 767-784.

O'Connel, C.P., 1980. Percentage of starving northern anchovy, Engraulis mordax, larvae in the sea as estimated by histological methods. Fishery Bulletin 78, 475-489. 
O'Connell, C.P., Paloma, P.A., 1981. Histochemical indications of liver glycogen in samples of emaciared and robust larvae of the northern anchovy, Engraulis mordax. Fishery Bulletin 79, 806-812.

Ohizumi, H., Kuramochi, T., Kubodera, T., Yoshioka, M., Miyazaki, N., 2003. Feeding habits of Dall's porpoises (Phocoenoides dalli) in the subarctic North Pacific and the Bering Sea basin and the impact of predation on mesopelagic micronekton. Deep-Sea Research I 50, 593-610.

Olivar, M.P., Beckley, L.E., 1997. Larval development of Lampanyctus species (Pisces: Myctophidae) from the southwestern Indian Ocean, and species groups based on larval characters. Bulletin of Marine Science 60, 47-65.

Olivar, M.P., Shelton, P.A., 1993. Larval fish assemblages of the Benguela Current. Bulletin of Marine Science 53, 450-474.

Oliveira, L.P., 2009. Análise comparativa da distribuição das famílias Salpidae e Doliolidae em relação ao zooplâncton total na plataforma continental sudeste do Brasil por meio de técnicas semi-automáticas de identificação e contagem. Dissertação de Mestrado. Universidade de São Paulo. 113 p.

Ozawa, T., 1986. Early life history of the family Myctophidae in the ocean off southern Japan. In Ozawa, T. (Ed.), Studies on the oceanic ichthyoplankton in the western North Pacific. Kyushu Univ Press, Hukuoka. pp. 114-187.

Prager, M.H., Saila, S.B., Recksiek, C.W., 1989. FISHPARM: a microcomputer program for parameter estimation of nonlinear models in fishery science, second edition. Old Dominion University Oceanography Technical Report, 8710.

Reid, K., Davis, D., Staniland, I.J., 2006. Spatial and temporal variability in the fish diet of Antarctic fur seal (Arctocephalus gazella) in the Atlantic sector of the Southern Ocean. Canadian Journal of Zoology 84, 1025-1037. 
Richards, W.J., 2007. Introduction. In: Richards, W.J. (Ed.), Early Stages of Atlantic Fishes: An Identification Guide for the Western North Atlantic. Volume I. pp. 1-70.

Robison, B.H., Bailey, T.G., 1981. Sinking rates and dissolution of midwater fish fecal matter. Marine Biology 65, 135-142.

Rodríguez-Graña, L., Castro, L., Loureiro, M., González, H.E., Calliari, D., 2005. Feeding ecology of dominant larval myctophids in an upwelling area of the Humboldt Current. Marine Ecology Progress Series 290, 119-134.

Rodrigues, R.R., Lorenzzetti, J.A., 2001. A numerical study of the effects of bottom topography and coastline geometry on the Southeast Brazilian coastal upwelling, Continental Shelf Research 21, 371-394.

Rooker, J.R., Holt, S.A., Holt, G.J., Fuiman, L.A., 1999. Spatial and temporal variability in growth, mortality, and recruitment potential of postsettlement red drum, Sciaenops ocellatus, in a subtropical estuary. Fishery Bulletin 97, 581590.

Rossi-Wongtschowski, C.L.D.B., Clemmesen, C., Ueberschär, B., Dias, J.F., 2003. Larval condition and growth of Sardinella brasiliensis (Steindachner, 1879): preliminary results from laboratory studies. Scientia Marina 67, 13-23.

Rothschild, B.J., 1991. Food signal theory: population regulation and the functional response. Journal of Plankton Research 13, 1123-1135.

Rothschild, B.J., Osborn, T.R. 1988. Small-scale turbulence and plankton contact rates. Journal of Plankton Research 10, 465-474.

Sabatés, A., Bozzano, A., Vallvey, I., 2003. Feeding pattern and the visual light environment in myctophid fish larvae. Journal of Fish Biology 63, 1476-1490.

Sabatés, A., Saiz, E., 2000. Intra- and interspecific variability in prey size and niche 
breadth of myctophiform fish larvae. Marine Ecology Progress Series 201, 261271.

Santamaría, C.A., Marín de Mateo, M., Traveset, R., Sala, R., Grau, A., Pastor, E., Sarasquete, C., Crespo, S., 2004. Larval organogenesis in common dentex Dentex dentex L. (Sparidae): histological and histochemical aspects. Aquaculture 237, 207-228.

Santos, A.P., 2003. Estudos sobre a taxonomia e a distribuição dos peixes da família Myctophidae (Actinopterygii: Myctophiformes) no sudeste e sul do Brasil. Dissertação de Mestrado. Universidade de São Paulo. 108 p.

Santos, A.P., Figueiredo, J.L., 2008. Guia de Identificação dos peixes da família Myctophidae do Brasil. Edusp. São Paulo. 168 p.

Sassa, C. 2010. Feeding ecology of Symbolophorus californiensis larvae (Teleostei: Myctophidae) in the southern transition region of the western North Pacific. Journal of the Marine Biological Association of the United Kingdom 90, $1249-1256$.

Sassa, C., Kawaguchi, K., 2004. Larval feeding habits of Diaphus garmani and Myctophum asperum (Pisces: Myctophidae) in the transition region of the western North Pacific. Marine Ecology Progress Series 278, 279-290.

Sassa, C., Kawaguchi, K., 2005. Larval feeding habits of Diaphus theta, Protomyctophum thompsoni, and Tarletonbeania taylori (Pisces: Myctophidae) in the transition region of the western North Pacific. Marine Ecology Progress Series 298, 261-276.

Sassa C., Kawaguchi K., Hirota, Y., Ishida, M. 2007. Distribution depth of the transforming stage larvae of myctophid fishes in the subtropical - tropical waters of the western North Pacific. Deep-Sea Research Part I, 54: 21812193. 
Sassa, C., Kawaguchi, K., Loeb, V.J., 2003. Early development of Diaphus garmani (Myctophidae) in the transition region of the western North Pacific. Ichthyological Research 50, 94-97.

Sassa, C., Kawaguchi, K., Mori, K. 2004a. Late winter larval mesopelagic fish assemblage in the Kuroshio waters of the western North Pacific. Fisheries Oceanography 13, 121-133.

Sassa C., Kawaguchi, K., Oozeki, Y., Kubota, H., Sugisaki, H. 2004b. Distribution patterns of larval myctophid fishes in the transition region of the western North Pacific. Marine Biology 144, 417-428.

Sassa, C., Moser, H.G., Kawaguchi, K., 2002. Horizontal and vertical distribution patterns of larval myctophid fishes in the Kuroshio Current region. Fisheries Oceanography 11, 1-10.

Satoh, K., Tanaka, Y., Masujima, M., Okazaki, M., Kato, Y., Shono, H., Suzuki, K., 2012. Relationship between the growth and survival of larval Pacific bluefin tuna, Thunnus orientalis. Marine Biology 160, 691-702.

Secor, D.H., Dean, J.M., Laban, E.H., 1992. Otolith removal and preparation for microstructural examination. In: Stevenson, D.K., Campana, S.E. (Eds.), Otolith Microstructure Examination and Analysis. Canadian Special Publication of Fisheries and Aquatic Sciences 117. pp. 19-57.

Sieg, A., 1992a. A histological study on the nutritional condition of larval and metamorphosing fishes of the genus Vincinguerria (Photichthyidae) sampled in two contrasting environments. Journal of Applied Ichthyology 8, 154-163.

Sieg, A., 1992b. Histological study of organogenesis in the young stages of the mesopelagic fish Vincinguerria (Photichthyidae, Pisces). Bulletin of Marine Science 50, 97-107. 
Sieg, A., 1998. A study on the histological classification of the in situ-nutritional conditional of larval South-west Atlantic anchovy, Engraulis anchoita Hubbs and Marini, 1935. Archives of Fisheries and Marine Research 46, 19-36.

Signorini, S.R., 1978. On the circulation and the volume transport of the Brazil Current between the Cape of São Tomé and Guanabara Bay. Deep Sea Research 25, 481-490.

Silveira, I.C.A., Miranda, L.B., Brown, W.S., 1994. On the origins of the North Brazil Current, Journal of Geophysical Research 99, 22501-22512.

Silveira, I.C.A., Schmidt, A.C.K., Campos, E.J.D., Godoi, S.S., Ikeda, Y., 2000. A Corrente do Brasil ao Largo da Costa Leste Brasileira. Revista Brasileira de Oceanografia 48, 171-183.

Simms, J.R., Rooker, J.R., Holt, S.A., Holt, G.J., Bangma, J., 2008. Distribution, growth, and mortality of sailfish (Istiophorus platypterus) larvae in the northern Gulf of Mexico. Fishery Bulletin 108, 478-490.

Soares, I., Möller, O.J., 2001. Low-frequency currents and water mass spatial distribution on the southern Brazilian shelf. Continental Shelf Research 21, $1785-1814$.

Soliman, B.V., Yamada, H., Yamaoka, K., 2009. Validation of daily sagittal increments in the golden-spotted rabbitfish Siganus guttatus (Bloch) using known-age larvae and juveniles. Journal of Applied Ichthyology 25, 438-441.

Takagi, K., Yatsu, A., Moku, M., Sassa, C., 2006. Age and growth of lanternfishes, Symbolophorus californiensis and Ceratoscopelus warmingii (Myctophidae), in the Kuroshio-Oyashio transition zone. Ichthyological Research 53, 281-289.

Tam, J., Purca, S., Duarte, L.O., Blaskovic, V., Espinoza, P., 2006. Changes in the diet of hake associated with El Niño 1997-1998 in the northern Humboldt Current ecosystem. Advances in Geosciences 6, 63-67. 
Tam, J., Taylor, M.H., Blaskovic, V., Espinoza, P., Ballón, R.M., Díaz, E., Wosnitza-Mendo, C., Argüelles, J., Purca, S., Ayón, P., Quipuzcoa, L., Gutiérrez, D., Goya, E., Ochoad, N., Wolff, M., 2008. Trophic modeling of the Northern Humboldt Current Ecosystem, Part I: Comparing trophic linkages under La Niña and El Niño conditions. Progress in Oceanography 79, 352365.

Ter Braak, C.J.F., 1986. Canonical Correspondence Analysis: A new Eigenvector technique for multivariate direct gradient analysis. Ecology 67, 1167-1179.

Ter Braak, C.J.F., Prentice, I.C., 1988. A theory of gradiente analysis. Advances in Ecological Research 18, 271-317.

Ter Braak, C.J.F., Verdonschot, P.F.M., 1995. Canonical correspondence analysis and related multivariate methods in aquatic ecology. Aquatic Sciences 57, 255-289.

Theilacker, G.H., 1986. Starvation-induced mortality of young sea-caught jack mackerel, Trachurus symmetricus, determined with histological and morphological methods. Fisheries Science 84, 1-17.

Theilacker, G.H., Porter, S.M., 1995. Condition of larval walleye pollock, Theragra chalcogramma, in the western Gulf of Alaska assessed with histological and shrinkage indices. Fishery Bulletin 93, 333-344.

Valinassab, T., Pierce, G.J., Johannesson, K., 2007. Lantern fish (Benthosema pterotum) resources as a target for commercial exploitation in the Oman Sea. Journal of Applied Ichthyology 23, 573-577.

Watanabe, Y., 1985. Histological changes in the liver and intestine of freshwater goby larvae during short-term starvation. Bulletin of the Japanese Society of Scientific Fisheries 51, 707-709. 
Weihs, D., Moser, H.G., 1981. Stalked eyes as an adaptation towards more efficient foraging in marine fish larvae. Bulletin of Marine Science 31, 31-36.

Young, J.W., Davis, T.L.O., 1990. Feeding ecology of larvae of southern bluefin, albacore and skipjack tunas (Pisces: Scombridae) in the eastern Indian Ocean. Marine Ecology Progress Series 61, 17-29.

Yúfera, M., Darias, M., 2007. The onset of exogenous feeding in marine fish larvae. Aquaculture 268, 53-63.

Zar, J.H., 1996. Biostatical analysis, 4th ed. Prentice Hall, Upper Saddle River, New Jersey. 663 p.

Zavalla-Camin, L.A., Grassi, R.T.B., Von Seckendorff, R.W., Tiago, G.G., 1991. Ocorrência de recursos epipelágicos na posição $22^{\circ} 11^{\prime} \mathrm{S}$ - 03955'W, Brasil. Boletim do Instituto de Pesca 18, 13-21.

Zembruscki, S.G. 1979. Geomorfologia da margem continental sul brasileira e das bacias oceânicas adjacentes. In: Chaves, H.A.F. (Ed.), Geomorfologia da margem continental sul brasileira e das bacias oceânicas adjacentes. Rio de Janeiro Petrobras, $177 \mathrm{p}$.

Zweifel, J.R., Lasker, R., 1976. Prehatch and posthatch growth of fishes- a general model. Fishery Bulletin 74, 609-621. 